


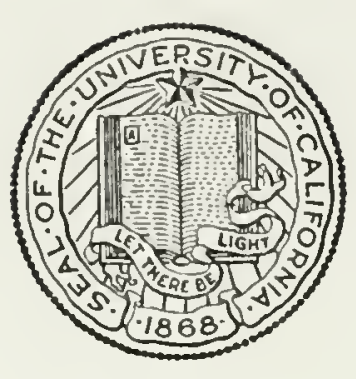

THE LIBRARY

$\mathrm{OF}$

THE UNIVERSITY

OF CALIFORNIA

DAVIS 



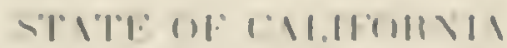

1)

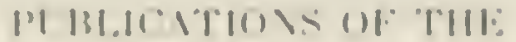

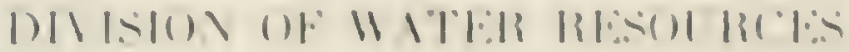

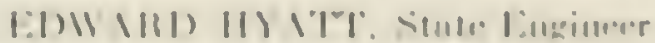

Reports on State Water Plan Prepared Pursuant to Chapter 832, Statutes of 1929

$$
\text { PLI.LEII \O.31 }
$$

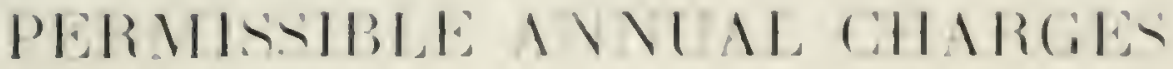
$+111$

\section{IRRIGATION II ATER}

IN IPPER SAI IOAOUIN MALLS

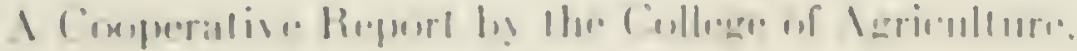
I'riverifs of lislifornia.

\section{0}

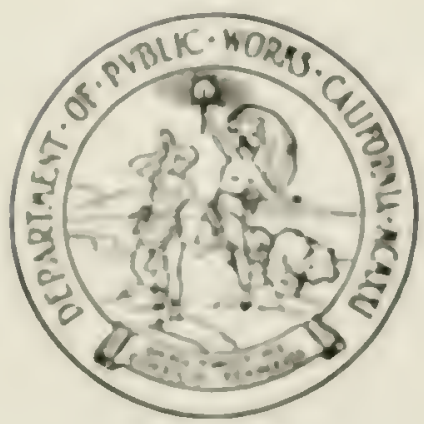




\section{TABLE OF CONTENTS}

$1 \times 16$

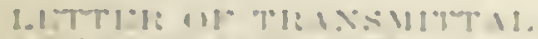

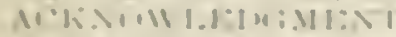

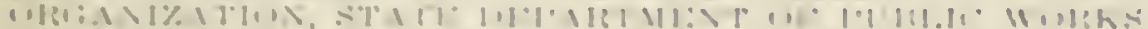

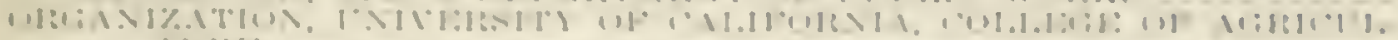
11 $1: 1:$

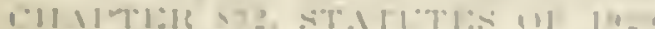

1+11:1:11,11:1,

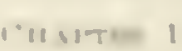

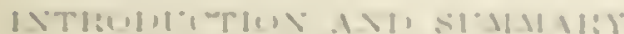

Mecluml or foritedurs

1

1 '11 wren 11

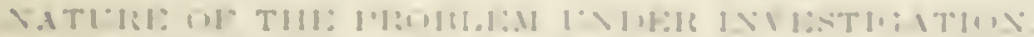

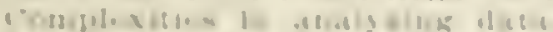

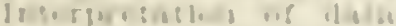

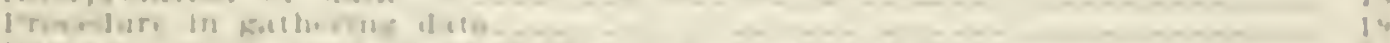

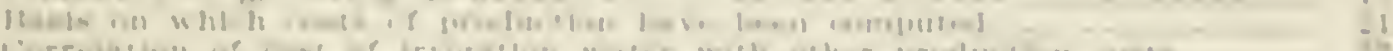

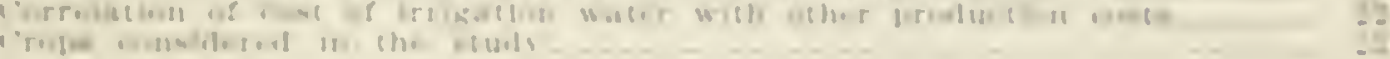

$10110 \mathrm{mon} 111$

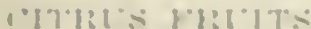

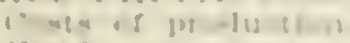

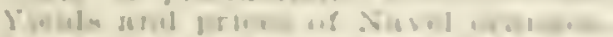

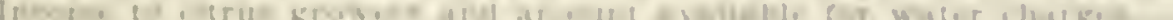

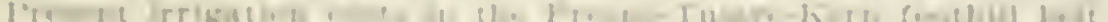

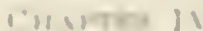

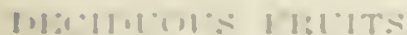

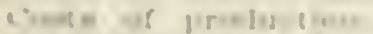

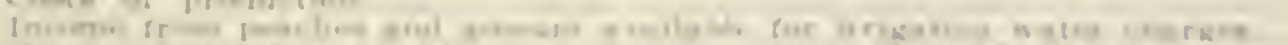

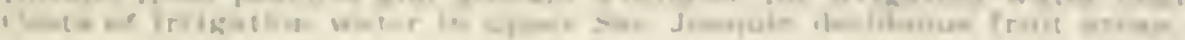

$1+11,4 x=1$

1.1811 .109

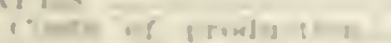

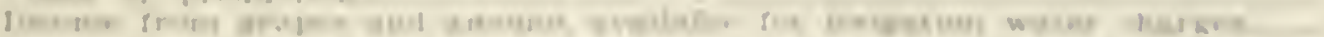

$\therefore$ insones!

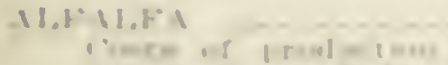

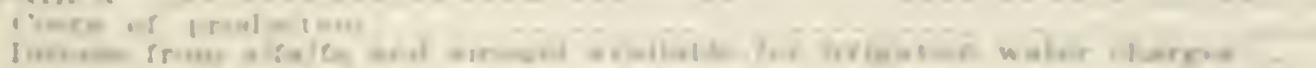

034 atore bil

1) $10,11 ., 1: 1,1 \%$

, r rair

intis

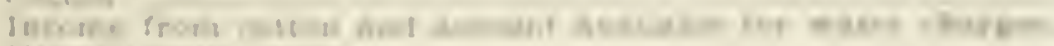

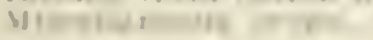

Constre 1.138

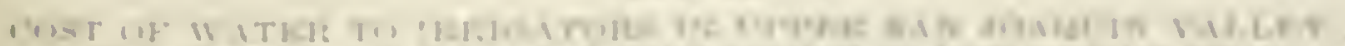

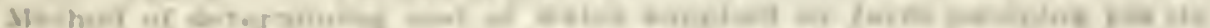

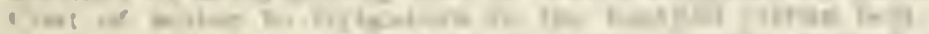

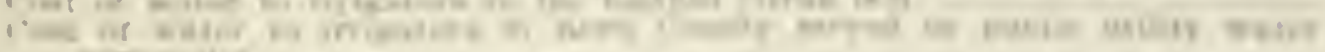

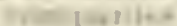

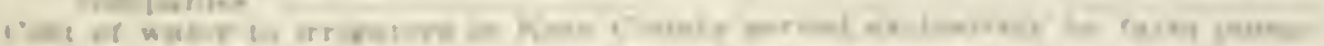

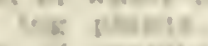

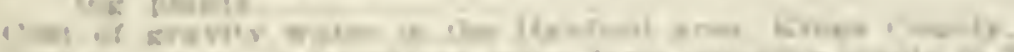

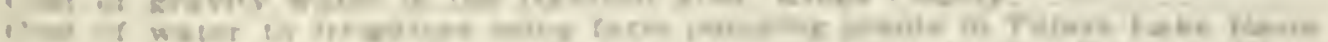

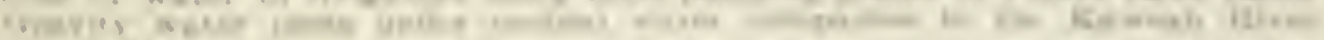
Inite

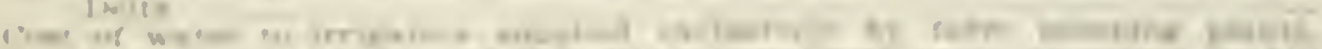

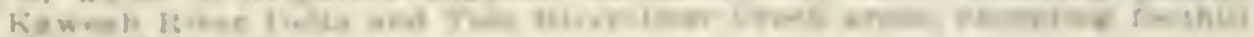
Cirum in:

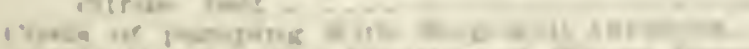

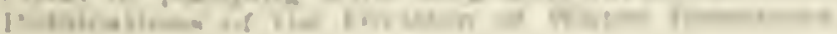




\section{LIST OF TABLES}

Table

1 Summary of data showing excess of estimated farm income over costs wer" acre of producing the principal crops grown in the upper San Joayuin Valley, plus interest on the average investment at 6 per cent per annum, cogethe+ with recommenderl permissible ammual rosts for irrigation water..-

2 Cost per acre of producing oranges in Fresno, Tulare and kern counties without allowance for interest or for irrigation water._._._.

3 Arerage cost per acre of producing and harvesting Vavel oranges in Fresno, 'Pulare and liern countits, segregated according to yield-_-

4 Arerage vield per acre in packed boxes of Navel oranges in Fresno, Tulare and kern counties, 1922-1927-

5 Average yield, price and return per acre for Navel oranges in Fresno and 'Julare counties, as shown by records from ten packing houses_._.....

6) Variation in yield of Navel oranges as shown by the production records of two packing houses in the Tulate citrus belt and by records for all California citrus Jocalities

i Average fon.h. prices pej lacked box received lor Navel oranges in the 'l'ulare citrus belt by the California Fruit Growers lixchange for November, December and January, 1914-15 to 1928-29--

$\$$ Cross income per acre to grower from oranges in the Tulare citrus belt with net price to grower of $\$ 1$ to $\$ 3.50$ per patekcd hox

9 Amounts per acre available from oranges in the lulare citrus belt for palying for irrigation water, interest on investment and profits...........

10 Average of $\$ 4$ records of pre-harvest cost of production of peaches in Tulaje County, 1926, 1927, 192S, 1929. Ages f years or more_______._.

11 Cost of poduction per acre for deciduous fruits on two large San Joaquin Valley tracts, $19 \div 9$

12 Budget estimates of a San Joaquin Valley bank covering cost of producing certain deciduous fruit.

13 Cost per acre of producing peaches as estimated by the Farm Management Siction, College of Anriculture, including interest and depreciation on implements and work stock__._.

14 Cost per acre of producing peaches as estimated ly the lam Management Section, College of Agriculture, nol including interest on implements and work stock, but including depreciation on trees___.

15) Average cost per acre of producing and harvesting peaches in Tulare County

If Iross income per acre to growers from peachess with yields of five to twelve

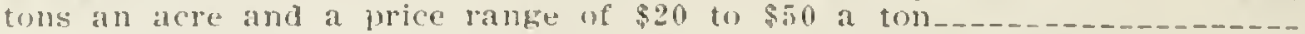

17 Data regarding cost of production wer acre for apricots, prumes and peaches, as reported in Agricultural Wxtension Service Circular 2t_-_..........

is drerage net profit or loss ner acre from production of certain deciduous fruits as reported in Agricultural lixtension Service Circular 24, College of Aficulture, Eniversity of California

1! Summary of data relating to the pro-harvest cost per acre of produching waljes, including fixed charges lut with no allowalue for irrigation water or Interest, $1: 126$ to $3 ! 12 ! 3$

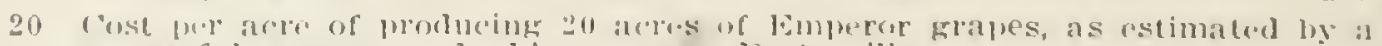

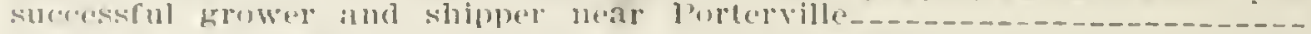

21 Iabur and matreial costs per acre on large acroge of vineyad at Delano, $1: 129$

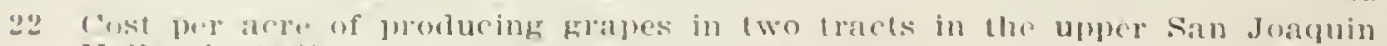
Villloy in $192 ! 3 !$

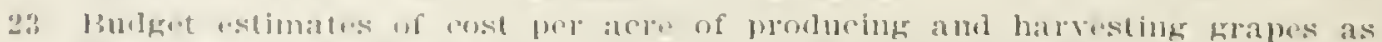

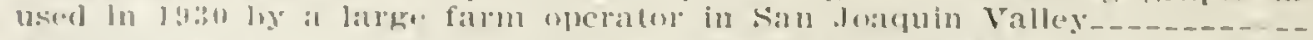

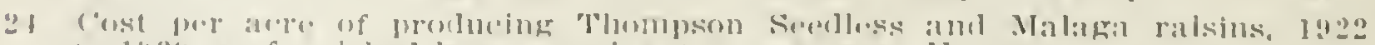

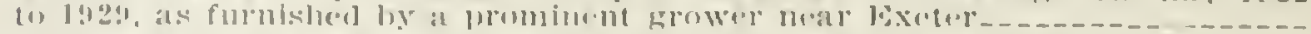

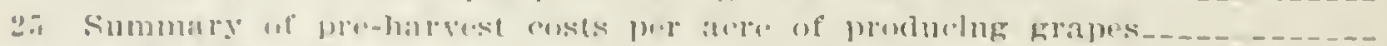

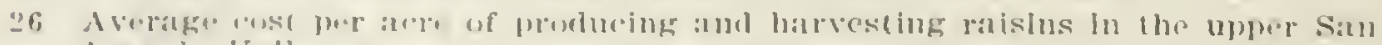
Joirquli V:alle.g.

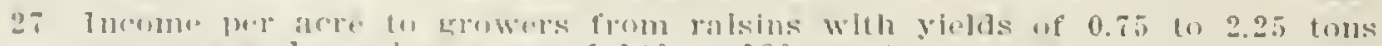

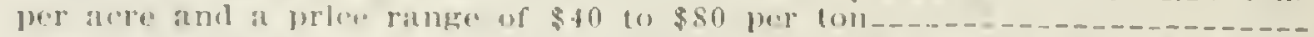

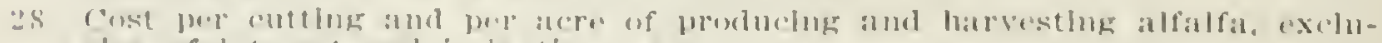
slver of luterest and irrifiatlon water

23 1

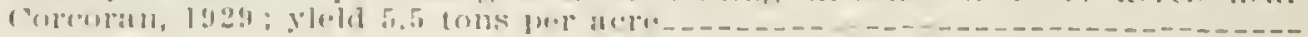




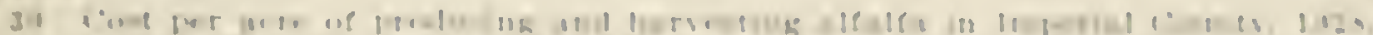

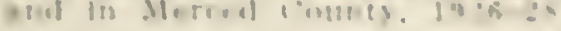

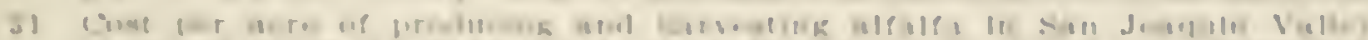

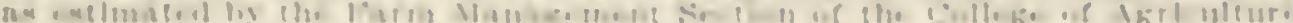

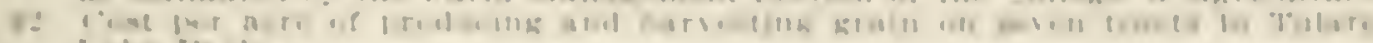
Ink. Itanlin.

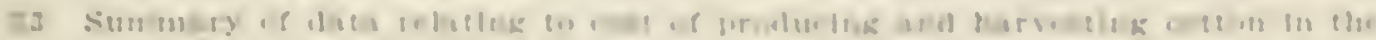

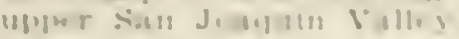

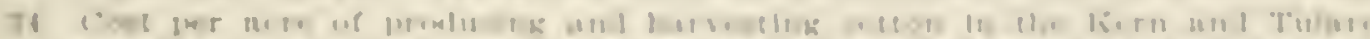

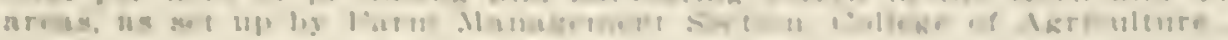

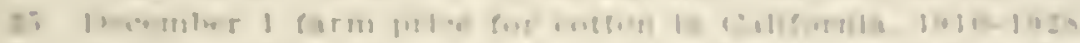

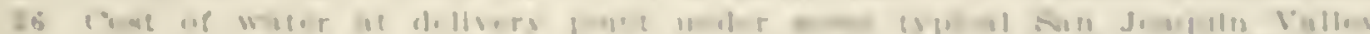

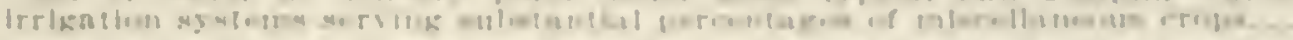

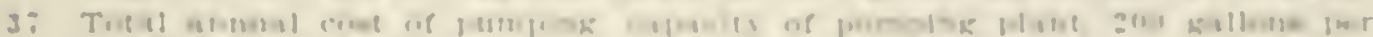
moluse. a

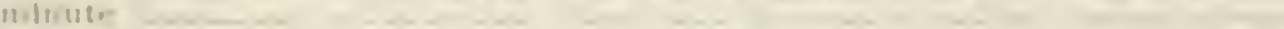

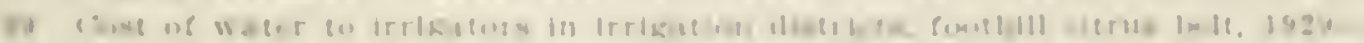

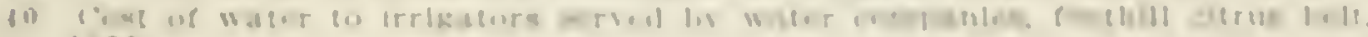
$1: 33$

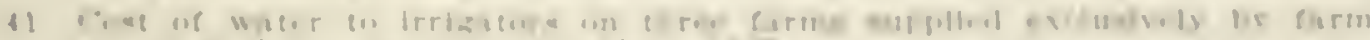

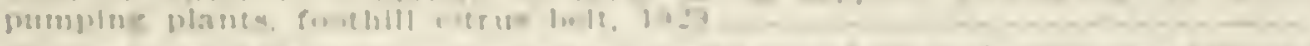

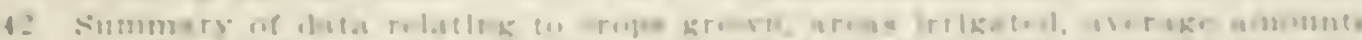

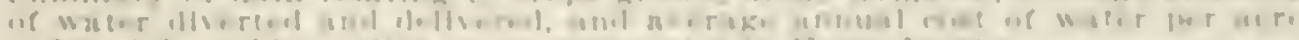

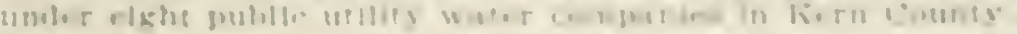

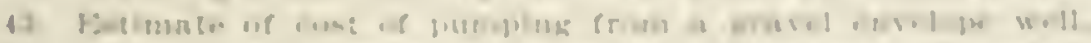

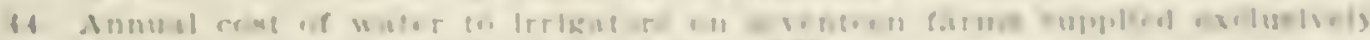

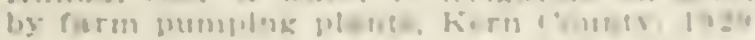

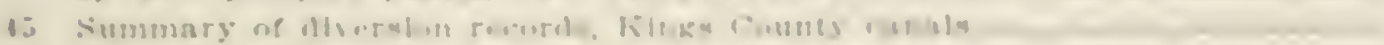

te leuner of hilnta I:Is.

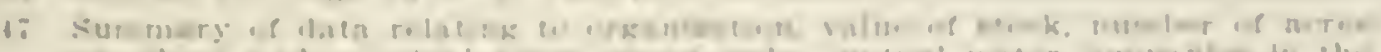

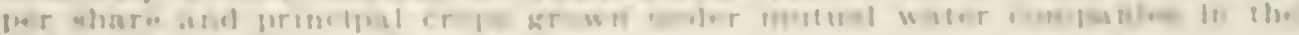

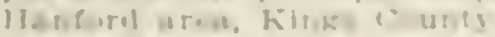

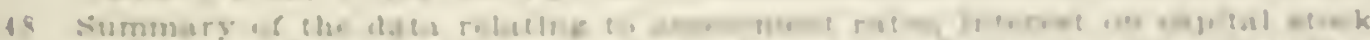

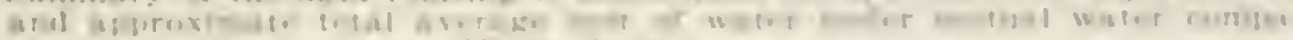

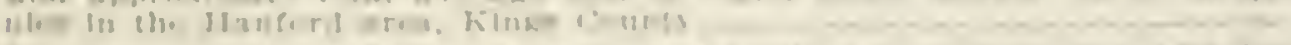

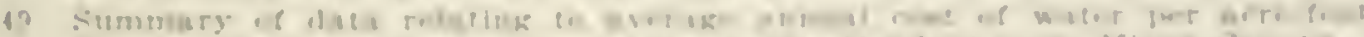

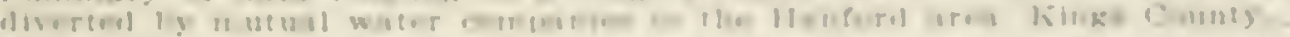

- Co

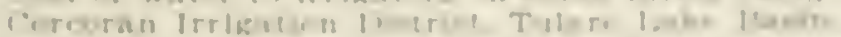

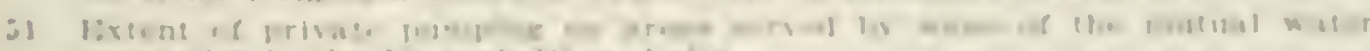

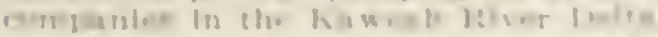

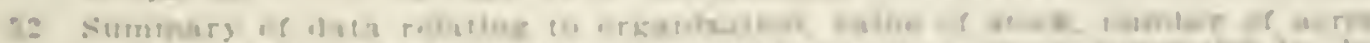

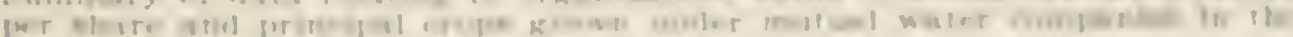

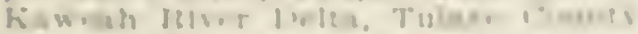

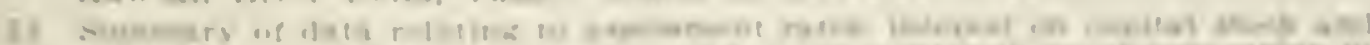

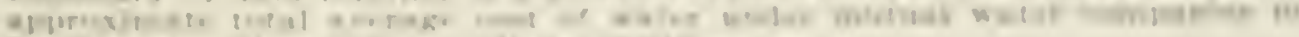

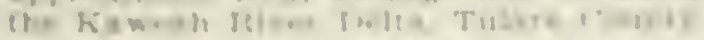

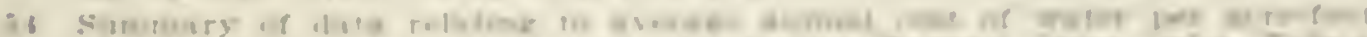

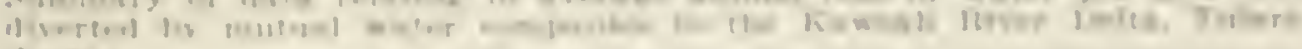
10 atos

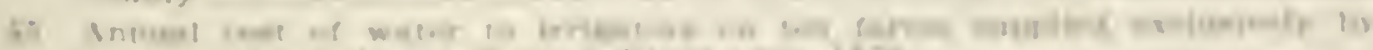

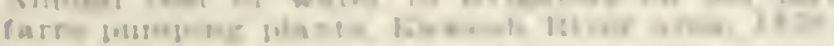

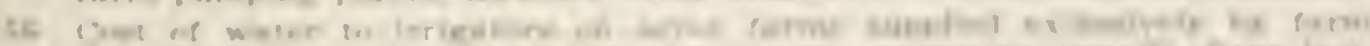

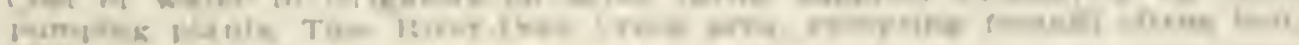
$i=2$.

\section{LIST OF PLATES}

lisis

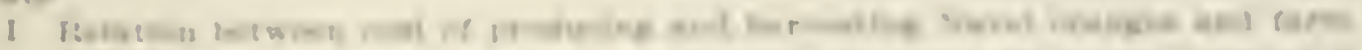

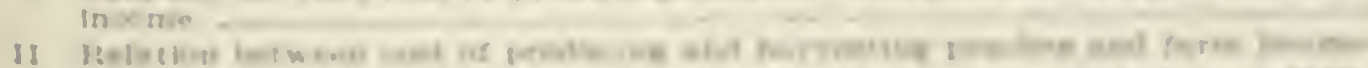

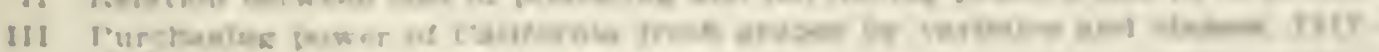
1956

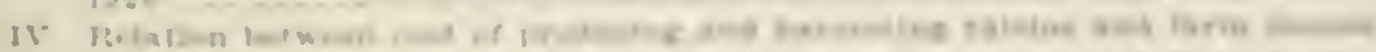

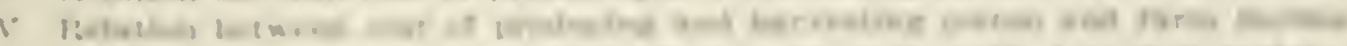

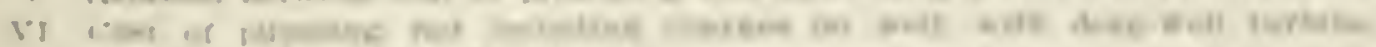

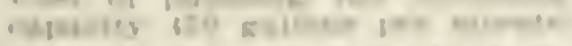

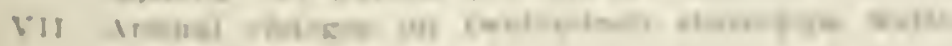




\section{LETTER OF TRANSMITTAL}

Mr. EDWARI HYATT,

State Engineer.

Sicramento, Califormiar.

Dear Sur: There is transmitted herewith a report entitled "Permissible Anmal Charges for Irrigation Water in Upper San . Toanuin Valley," by Frank Adams and Martin R. Iluberty. Attached to this report, as Chapter VIIJ, is a report entitlerl, "Present Cost of Water to Irrigator's in Upper San Joaquin Valley." by C. V. Givan and berald E. Christiansen.

This is one of two reports which rou regunested the College of Agriculture to prepare for you dealing with certain economic aspects of the State Water Plan.

You will recall that I appointed a committee from our staff to confer with you in comnection with ontlining the work, it being understood that this committee wonld also review the reports prior to their being forwarded to you.

This committee has eompleterl the task assigned to it in connection with the aceompany ing repolt. It has approved this report as presenting a reasonable analysis of the problem of what the farmers of Tpree San doatquin Valley can afford to pay for irrigation water, and as furnishing a basis for answering the questions asked. It therefore rereommenels tramsmittal of the report to your.

$$
\text { Very sincerely yours, }
$$

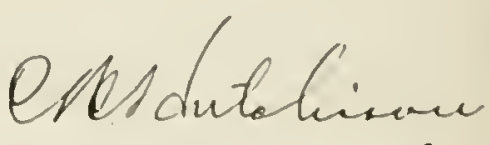

Dean, College of Agriculture.

lierlicley, ( allifomia.

(). lober :30, 1!:30. 


\section{ACKNOWLEDGMENT}

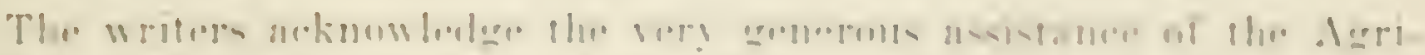

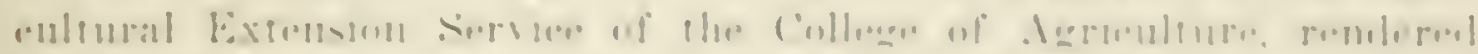

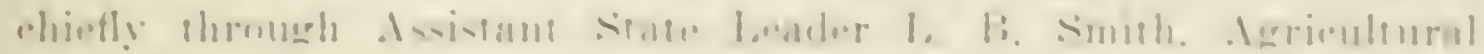

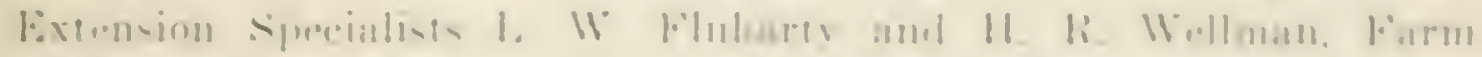

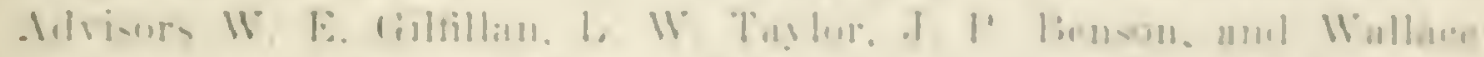

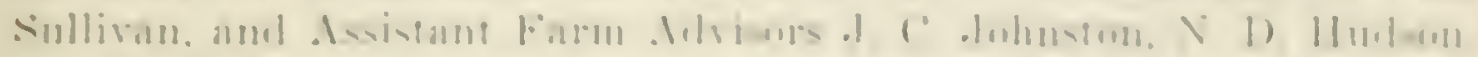

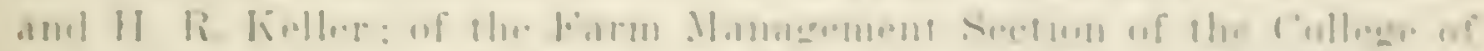

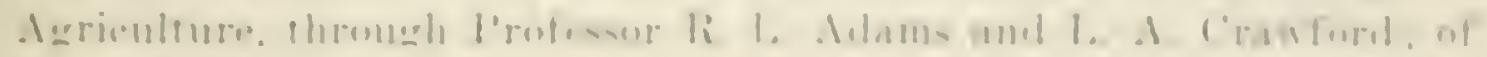

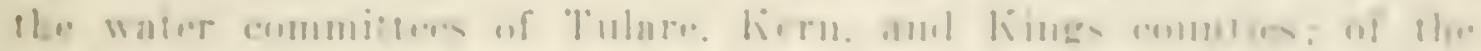

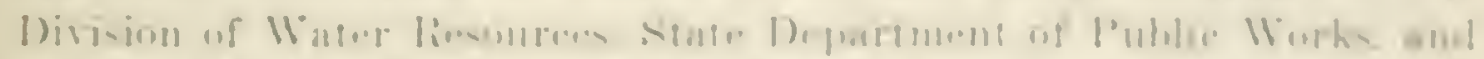

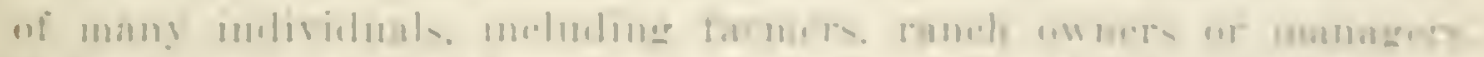

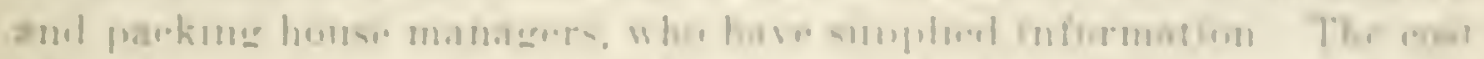

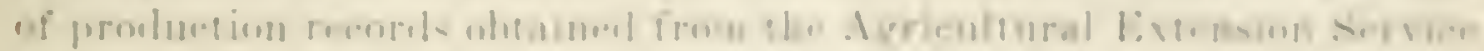

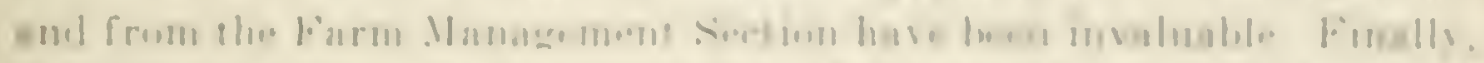

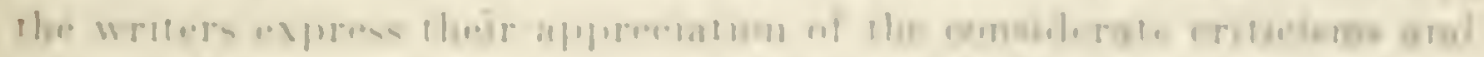

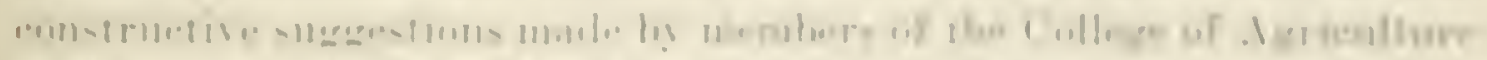

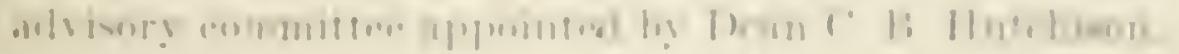




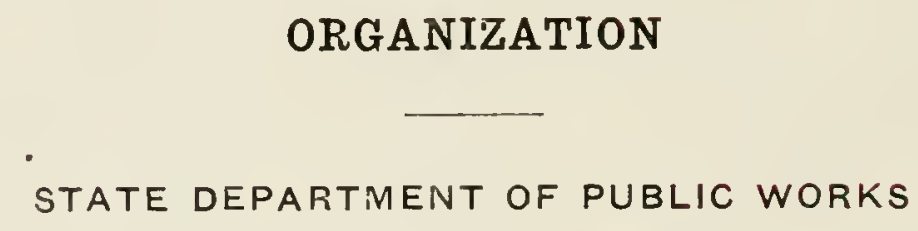

B. B. Mrek

Director

EDWARD IIYATT-

State Engineer

A. D. Enmoxstox

Deputy State Engincer 


\section{ORGANIZATION}

\section{UNIVERSITY OF CALIFORNIA, COLLEGE OF AGRICULTURE Cooperating in Water Resources Investigation}

(‥ H. HeT"Hsin: Dirm, Colleye of Agriculture

This report was prepared by

Frank Anams.

Profossur uf Irrigntion Indestigntions and Prastice.

and

Maktix R. Hublits.

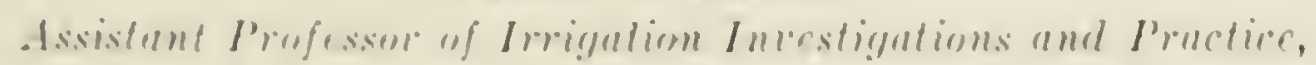
with the alvice and enopreration of the following eomuttee appoimted by the Dean of the (onllege of Agricult ure:

Frank Amas:

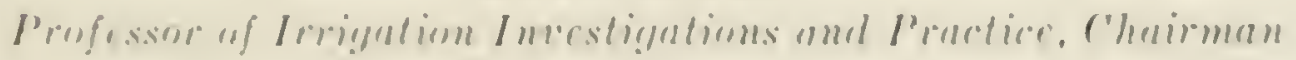

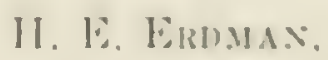

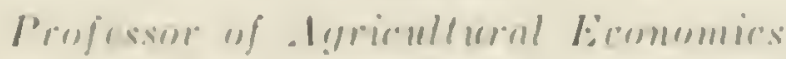

li. 1. Anims,

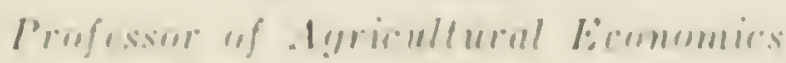

Darid Wraks.

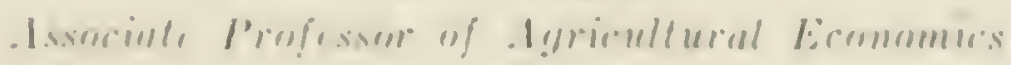

1. B. Sistril,

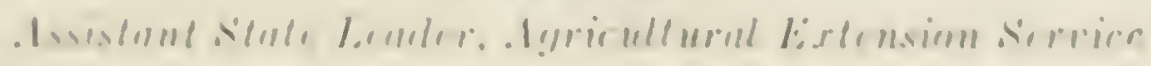

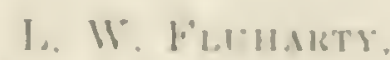

speciulest in flericullural listensiom 


\section{CHAPTER 832, STATUTES OF 1929}

In act makin! an appropriation for wort of crploration. investigation and pretiminary plans in furtherenee of a roordinated plan for the eonservation, derelopment, and utilization of the urater resouress of Califormin inctuding the santa Ana river. Wojave river and all water resources of southern California.

[I object to the item of $\$ \$ 50,000.00$ in section 1 and reduce the amount to $\$ 390$.orn.00. With this reduction I approve the isill. Dated lune 1i, 1929. C C. Youxa, Governor.]

\section{The people of the Situte of Cratiformin do enact as followis:}

SECTIOx 1. Ont of any money in the state treasmry not of herwise appropriated. the sum of four lumbed fifty thousand dollats. or so much thereof as may be necessary. is hereby appropriated to be expended by the state department of public worls in aceoldance with law in conducting work of exploration, investigation and preliminary plans in furtherance of a cooselinated plan for the conservation. development and utilization of the water pesoures of California including the Santa Ana rivel and its tributaries, the Mojave livel and its tributaries, and all other water resourees of southern California.

SEr. 2. The department of public works, subject to the other pro-

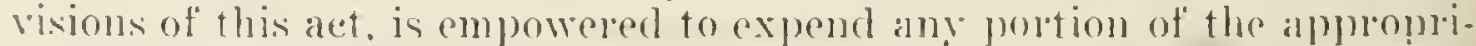
ation herein provided for the purposes of this act. in cooperation with the government of the Inited states of Ameriea ol in cooperation with political subdivisions of the State of California: and for the murpose

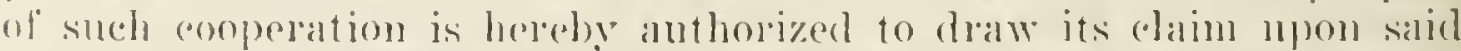

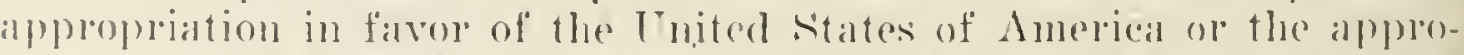

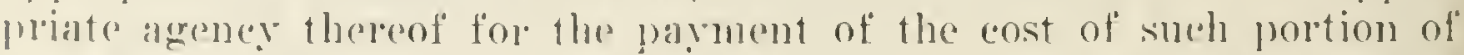
salid conporative work as may be determined by the department of pmblic works.

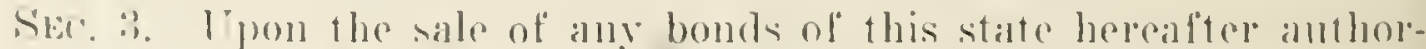
ized to he issmed to be expended for any one or more of the purpoegs - iol which ally part ol the applopletation herein provided may have

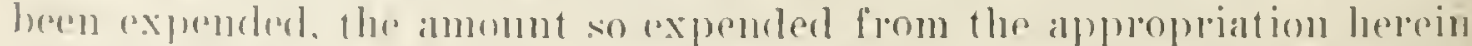

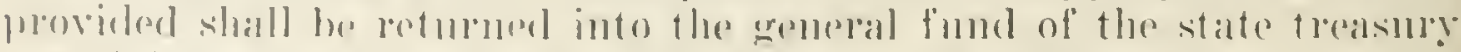
oul of the proceeds first derived from the sale of said bonts. 


\section{FOREWORD}

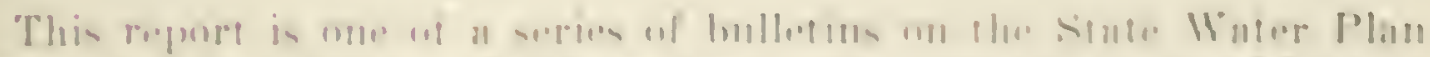

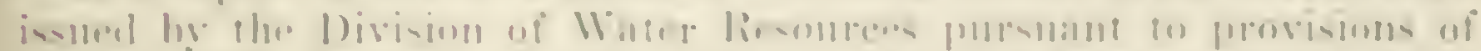

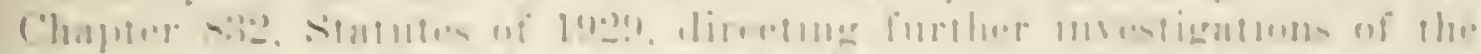

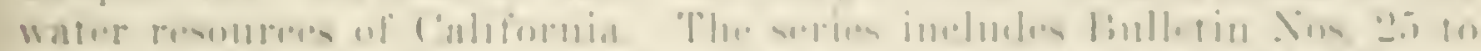

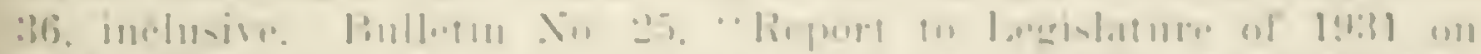

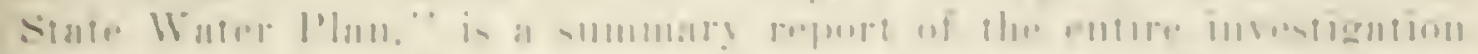

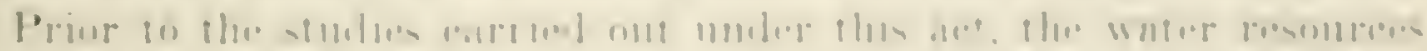

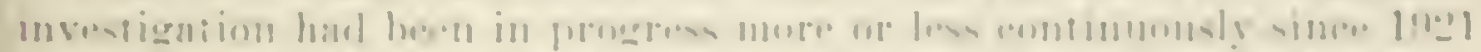

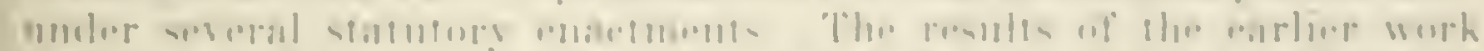
low

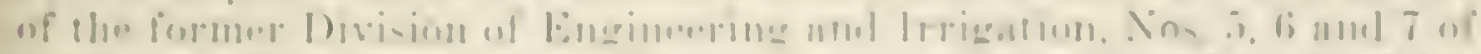

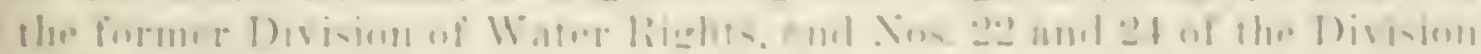

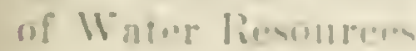

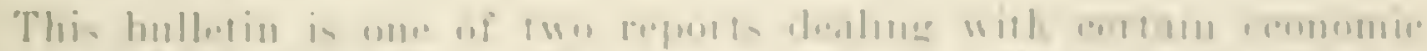

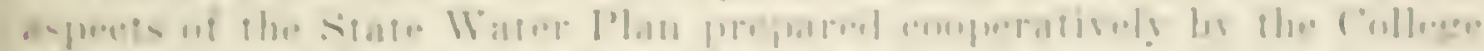

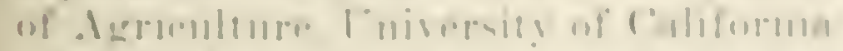

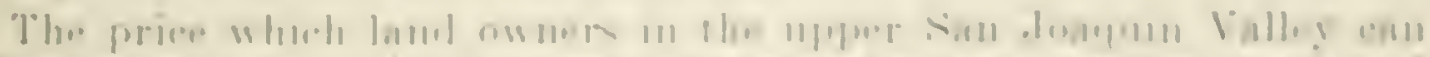

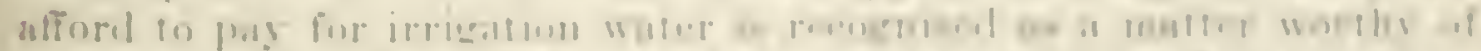

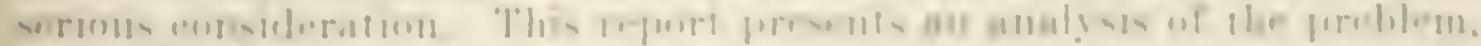

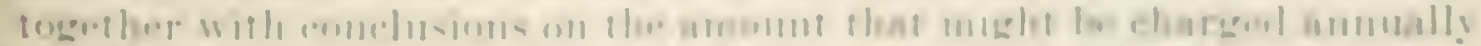

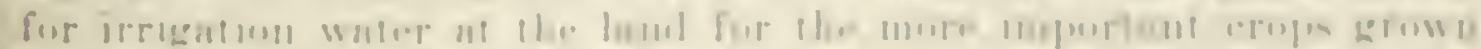

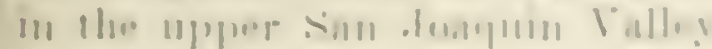




\section{('II.MPli:R I}

\section{INTRODUCTION AND SUMMARY}

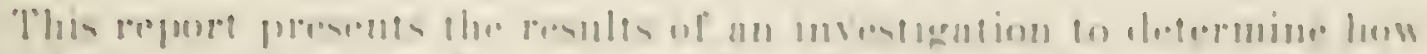

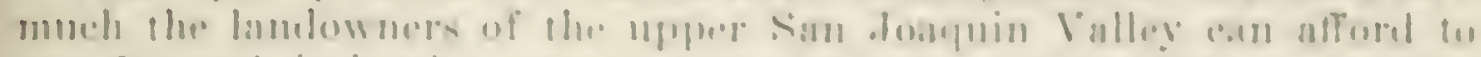

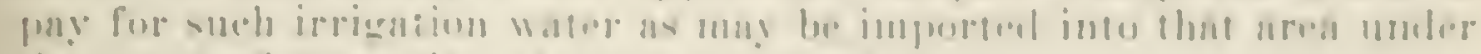
the propusent state plat

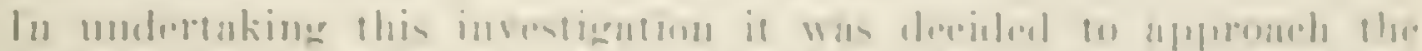

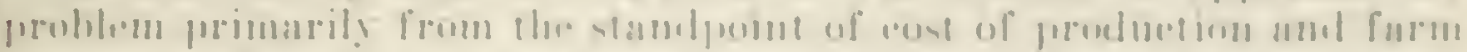

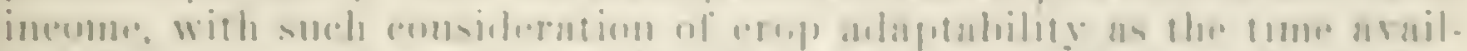

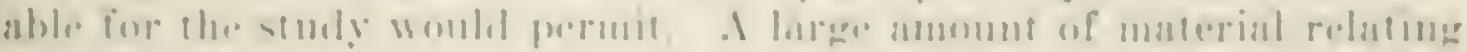

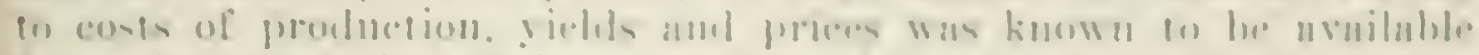

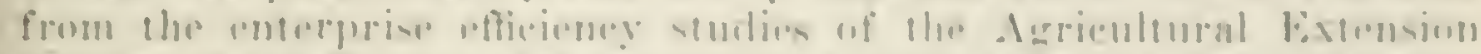

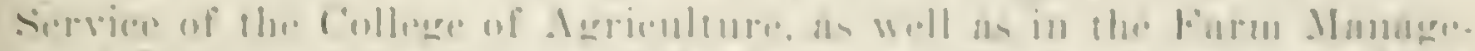

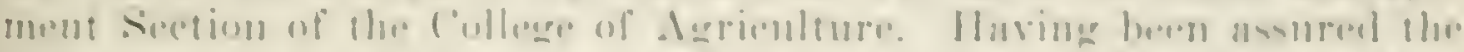

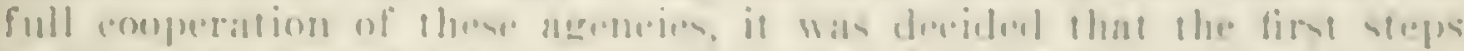

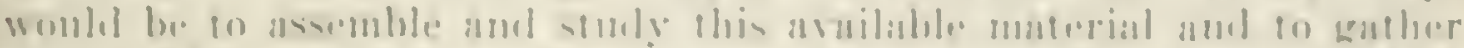

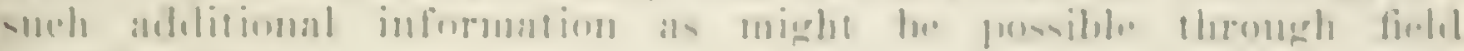
mverigations.

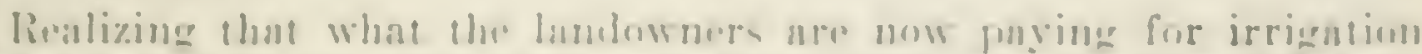
water would throw light on the gumben moler insestigation, informa-

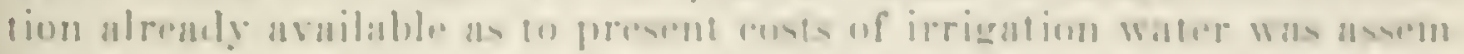

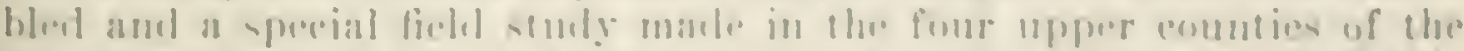

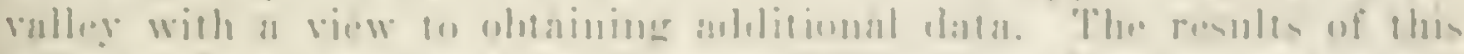

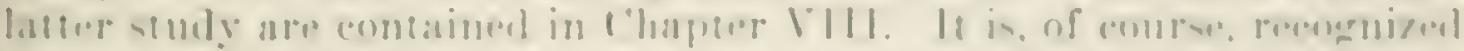

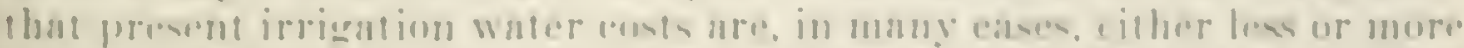
than in justifiol. amel therefore are not always a satisfarefors monstare of ." "peruisiblo" "haren.

\section{Method of Procedure.}

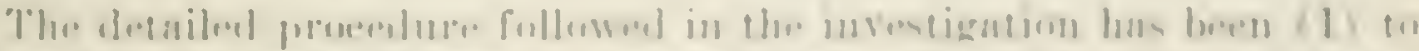

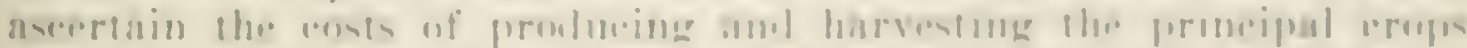

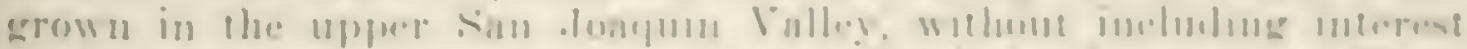

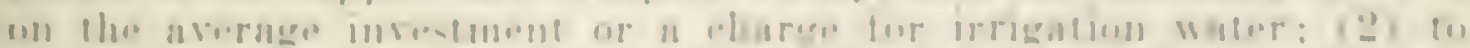

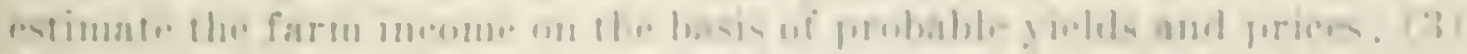

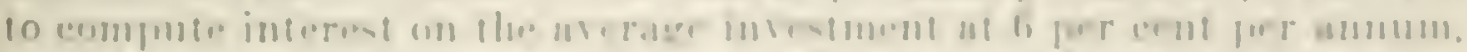

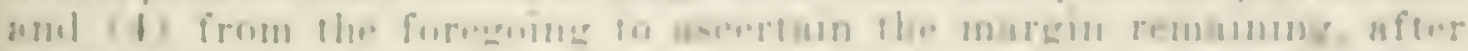

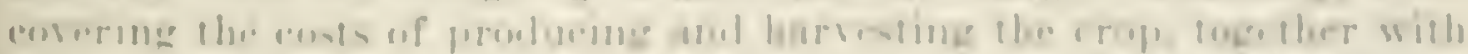

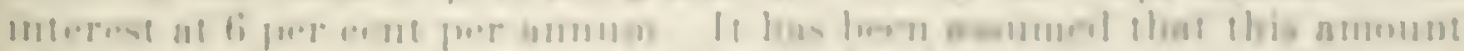

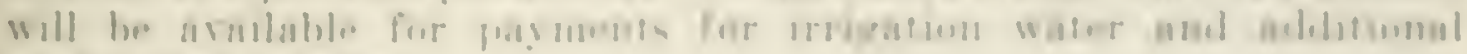
protits wsep intrermet

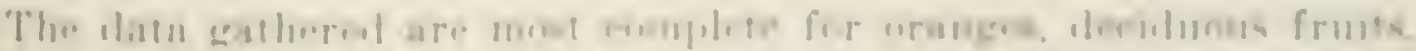

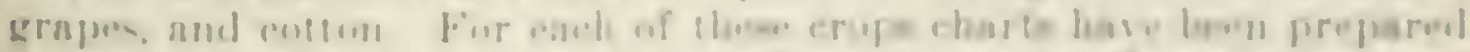

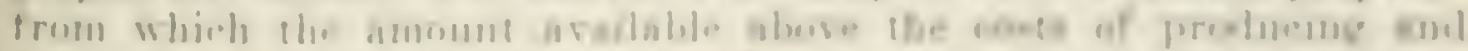

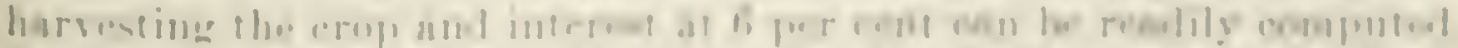

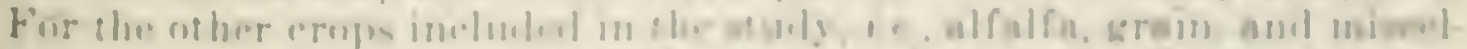

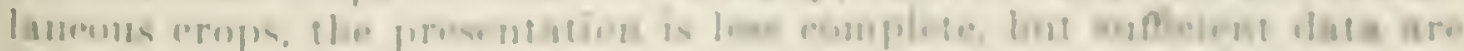

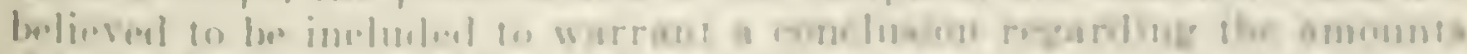

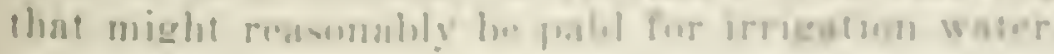


Table 1 show the exersis of finm income over the costs of producing and harvesting the crops considered, together with interest on the average investment at 6 per cent pep ammum; also the amounts it is believed an reasonab!y be paid for irrogation water.

The costs consideped permissible ale fol" a full supply ol watel" delivered at the land on which it is to be used. and alre therefore intended to include all such items as interest and principal payments on necessary eapital expenditures for irrigation works and water smpply. costs of maintenance and operation of irrigation works. as ordinarily moleristood, and smplemental pumping.

It is not sugesested that nome of the growers in the upper San Joaguin Valley can pay higher irrigation charges for the different erops studied than are arrived at herein. Some, of conrse, produce more than others. and there are wide difierences in the effieiency of arowers. types of farm enterprises, amount of working eapital avalable, and the mumerous other factors that determine cost of production and farm ineome. Neither is it suggested that the charges moposed can be paid by all of thr growers, this also being becalnse of the differences mentioned above. The permissible charges suggested are intended to be base charges which will be assessed in accoldance with the eallume capacity of the land: that is, on a benefit ol ad valorem basis.

The extent of the water emereney in the upper San .Joaguin Valley has not been taken into consideration in this investigation. Consequently, no attempt has bean made to determine what the growers can pay for water in ordel to save investments which would be lost or placed in jeopardy without importation of an additional water supply. Those mitters were considered out vide of the realm of the investigation.

TABLE 1

SUMIMARY OF DATA SIIOWING EXCESS OF ESTIMATED FARMI INCONIE OVER COSTS PER ACRE OF PRODUCING THE PRINCIPAL CROPS GROWN IN TIIE UPPER SAN JOAQUIN VALLEY, PLUS INTEREST ON THE AVERAGE INVESTMENT AT 6 PER CENT PER ANNUM, TOGETHER WITH RECOMMENDED PERMIISSIBLE ANNUAL COSTS FOR IRRIGATION WATER:

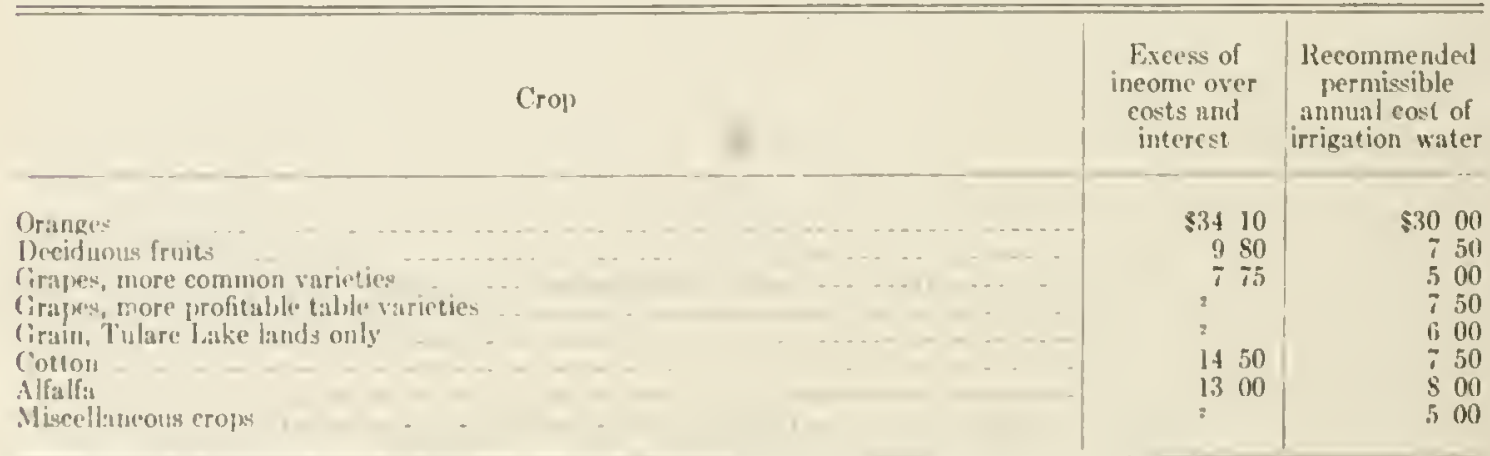

Irrigation water is not included in ents of proluetion. For basis on which farm income has been estimated sae statcruents regarding eich cron or group of ('rops convidured.

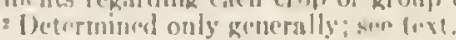

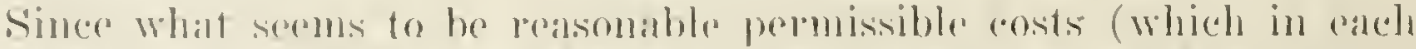

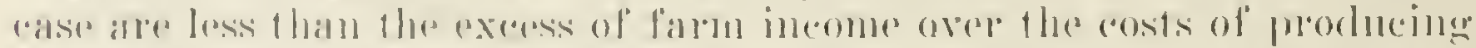

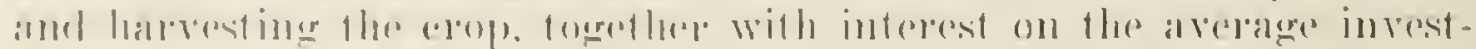

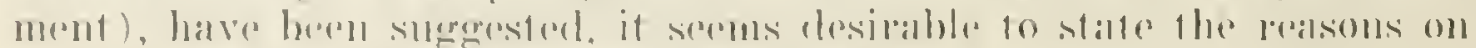

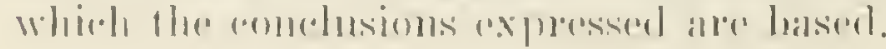




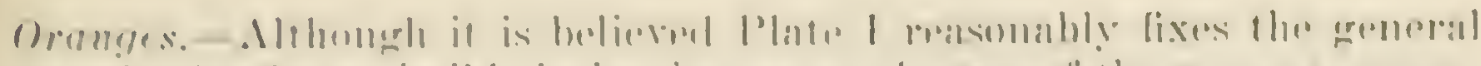

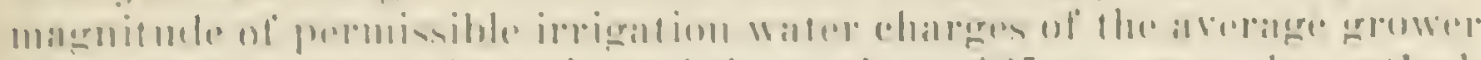

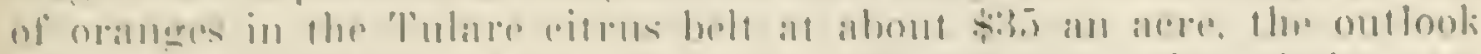

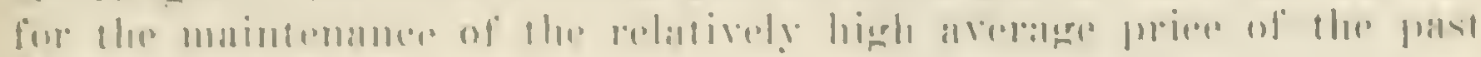

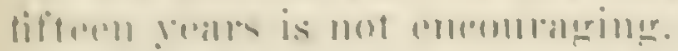

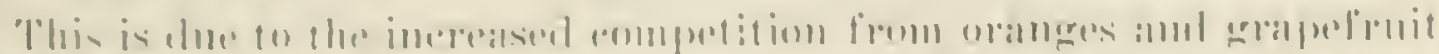

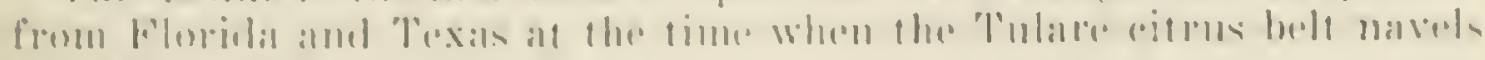
alre himpristerl.

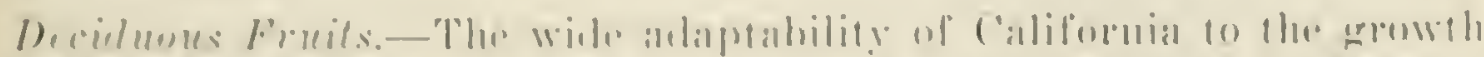

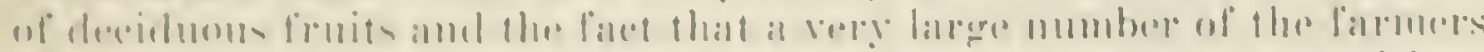

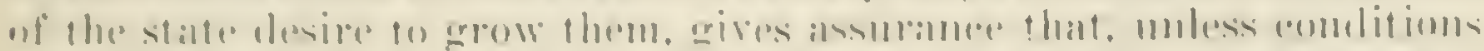

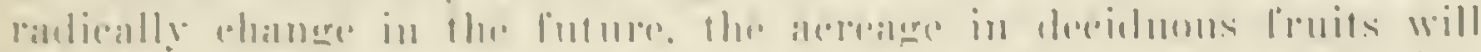

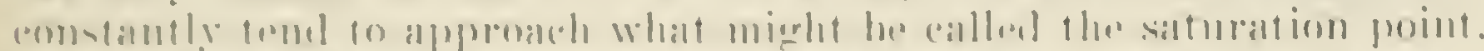

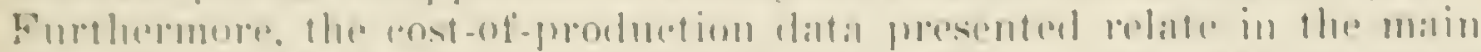

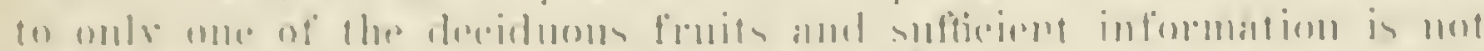

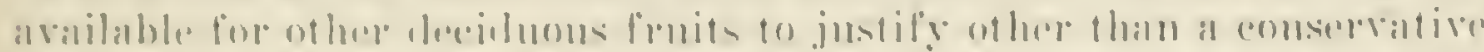

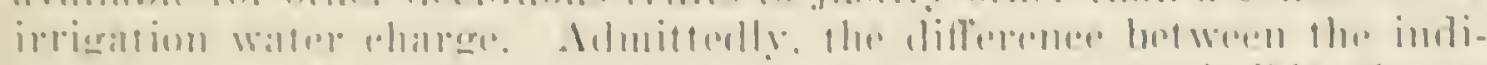

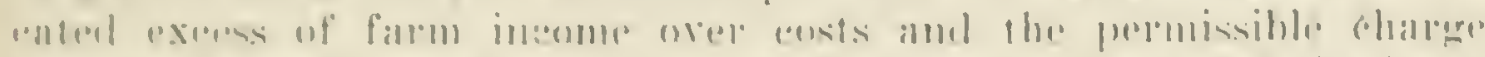

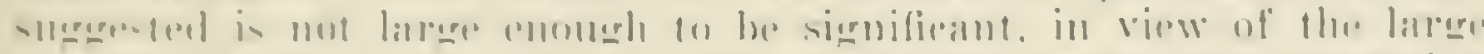

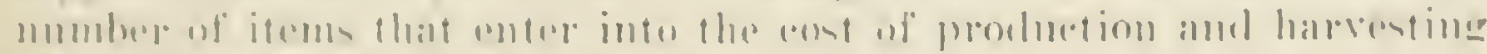

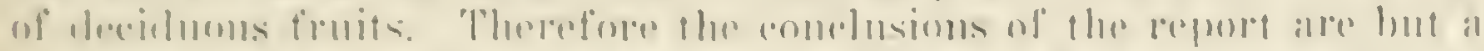

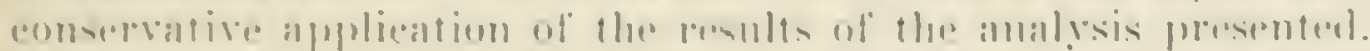

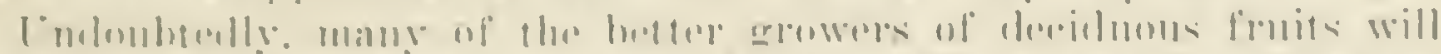

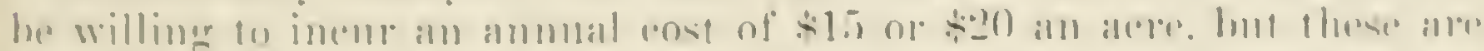

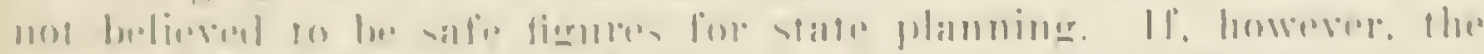
m1110.

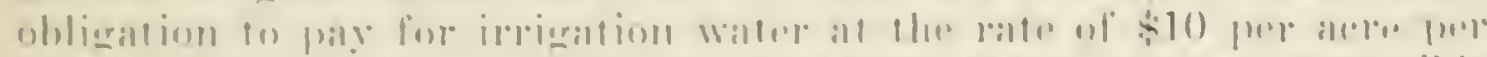

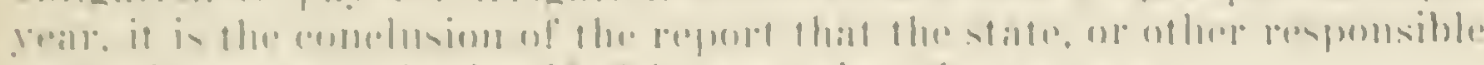

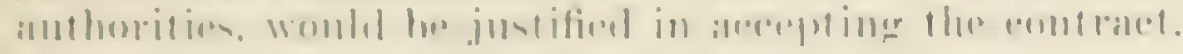

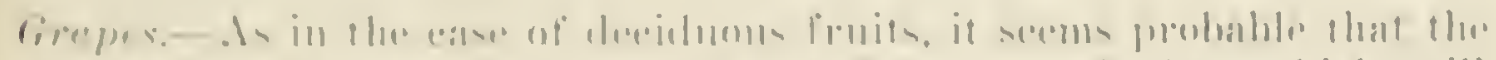

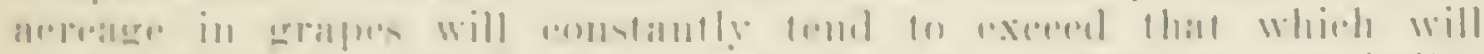

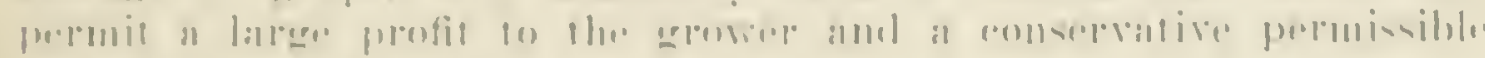

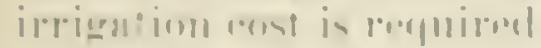

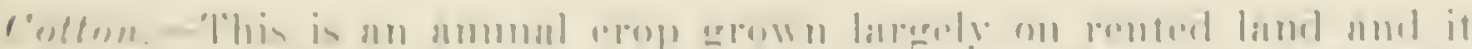

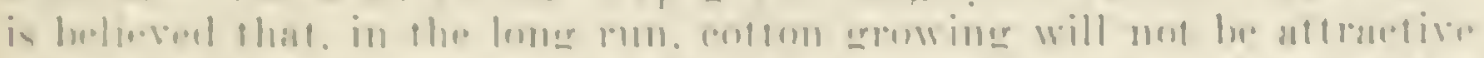

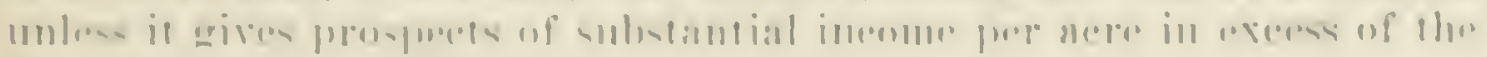

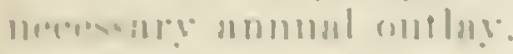

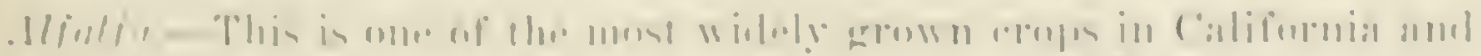

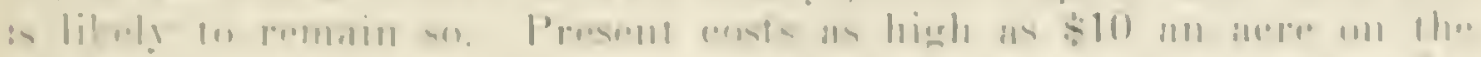

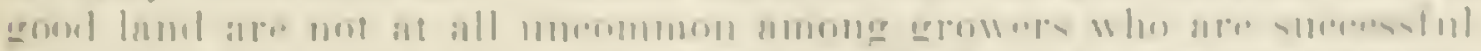

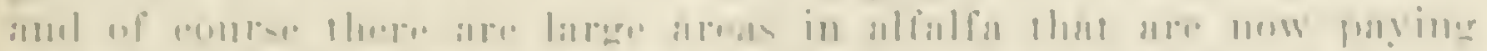

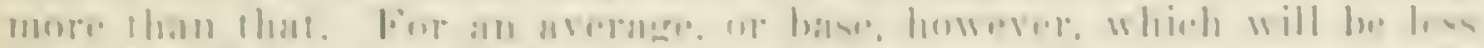

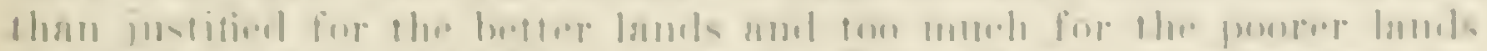

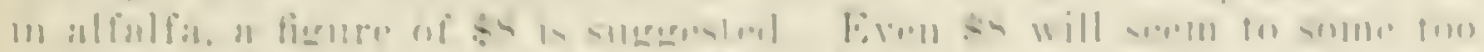

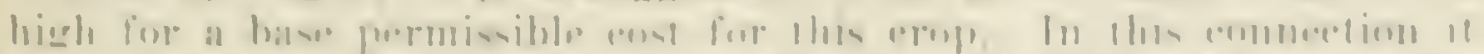

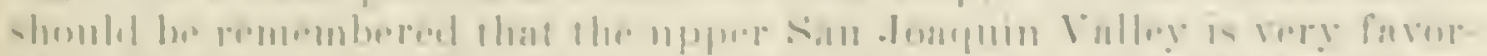

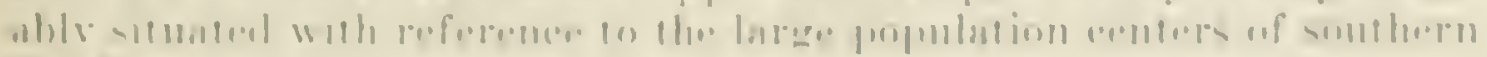
rillifurnis.

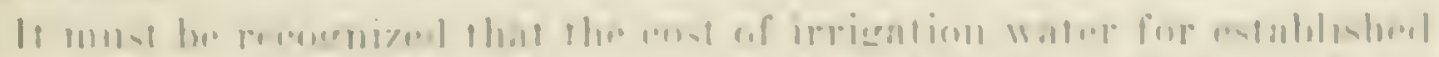

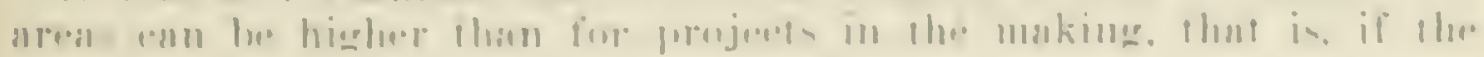


lands not in erop or still in low production must pay for water on the same or approximately the same basis as lands in full or approximatel full prodnction. All of the costs suggested in the above table are for land in established production.

One crop of some inportance in upper San Joarnin Valley, viz olives. is not eovered in the above summary and no data regarding the cost of producing this erop, or its income, have been given. On the basis of general information only, which classes the olive with such plantings as Emperor grapes and some citrus, a figure of $\$ 10$ per acr per year is sugrgested as a permissible irrigation water charge. Only the better varieties of olives could reasonably be elassed with citru fruits and for that reason the water cost suggested is much below tha for citrus. 


\section{( $11.11 \% 1 \% 1 \% 11$}

\section{NATURE OF THE PROBLEM UNDER INVESTIGATION}

\section{Complerities in Analyzing Data.}

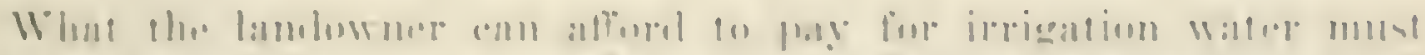

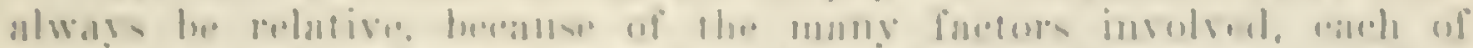

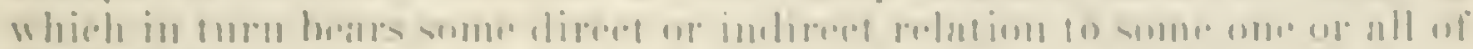
ilse whllerms.

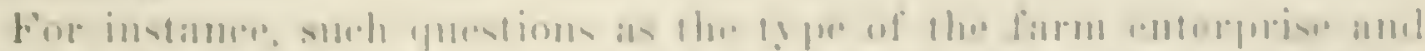

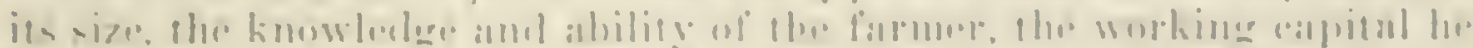

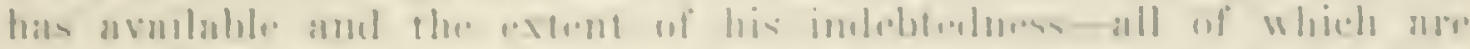

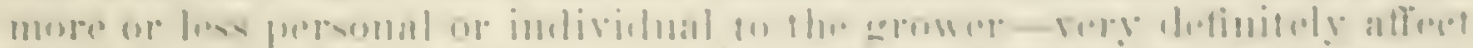

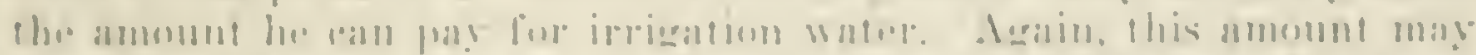

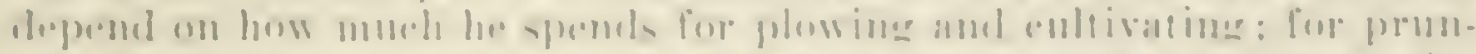

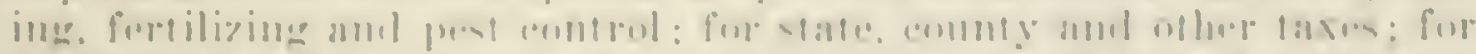

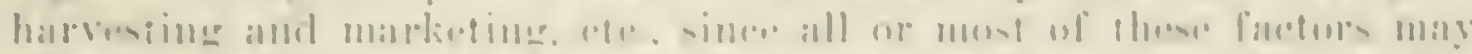

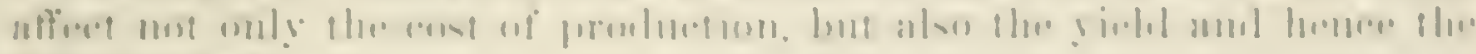
farm incomin.

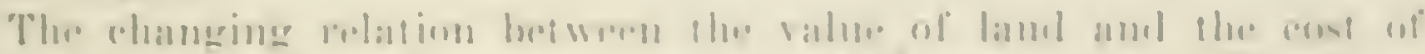

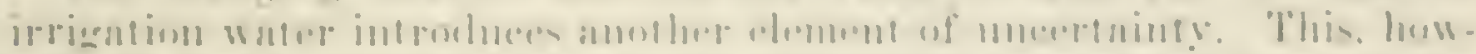

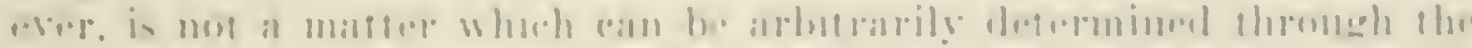

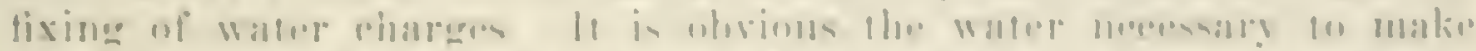

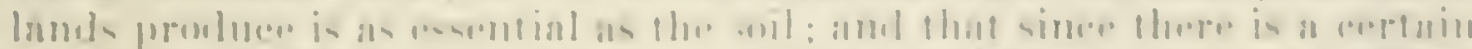

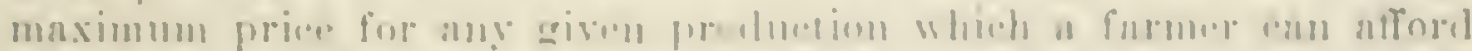

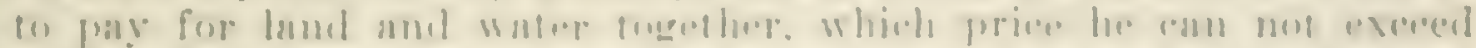

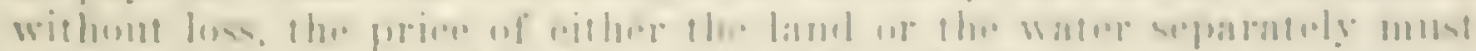

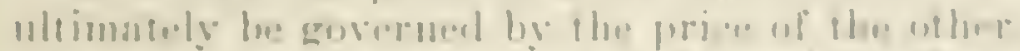

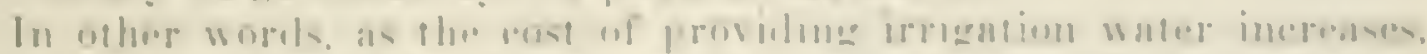

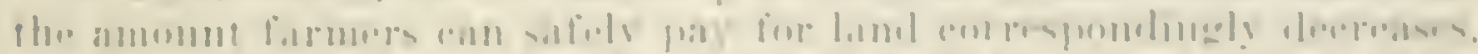

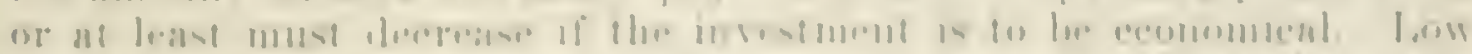

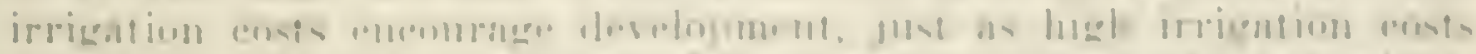

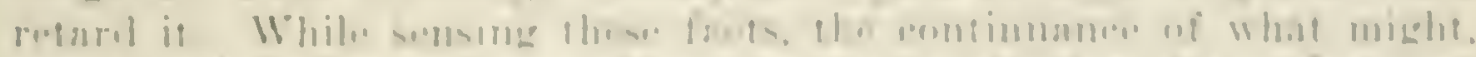

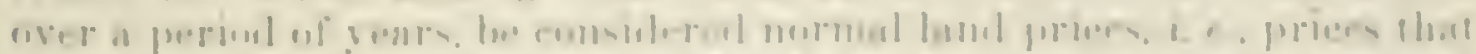

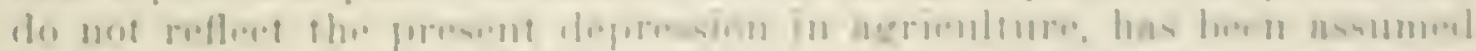

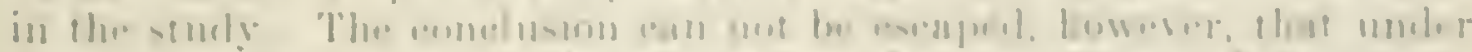

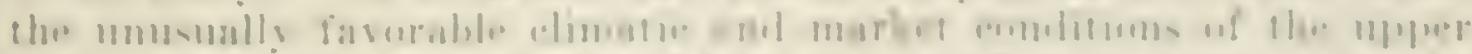

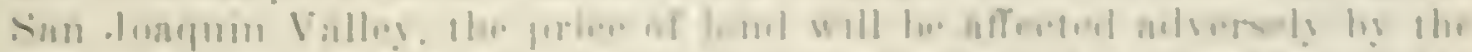

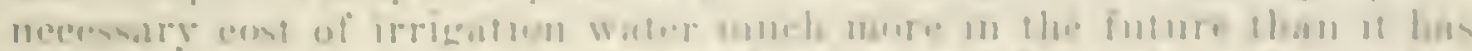

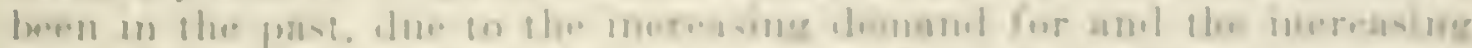

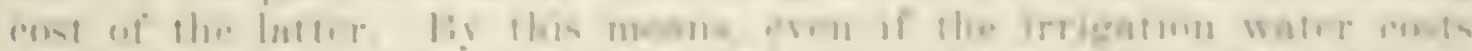

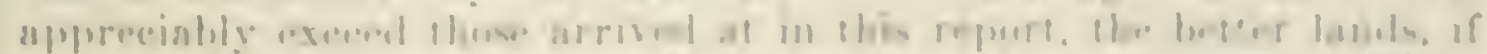

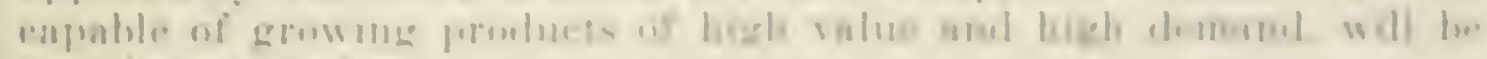
keple in pronluwions

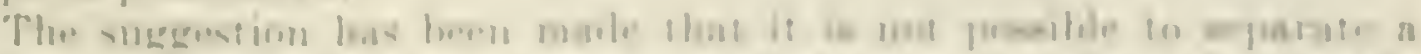

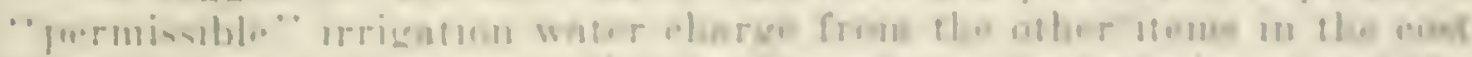

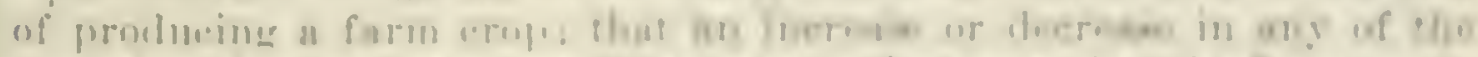

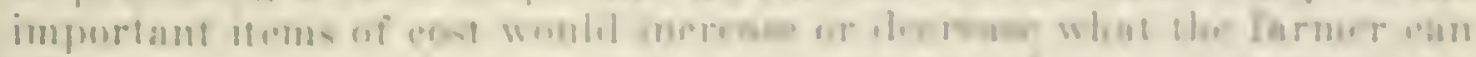

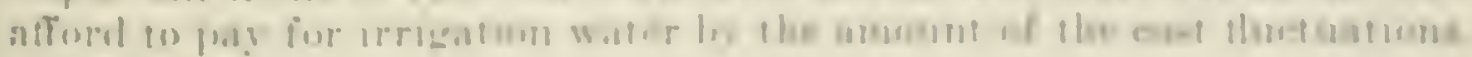


Granting this sepalration of the "premissible" water chare from the other cost ifems presents diffienlties. the writers believe such sepalrafion is nevertheless feasible, provided the total of the other items of cost can be reasomably determined lrom the data arabable. It is belicreel such is the case and the study has proceeded aceorelingly.

\section{Interpretation of Data.}

It is clear fon what has been stated above that the variation in cost

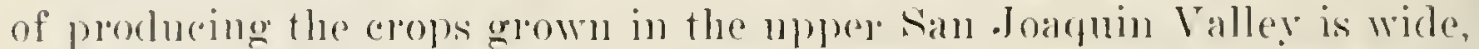
and that. due to this valuation. what one farmer ean afford to pay for wale with any given rield and price may be more ol less than another "all pay. with the same yold and price. It may be stated further that ome whose cost of production is higher than that of others may still be

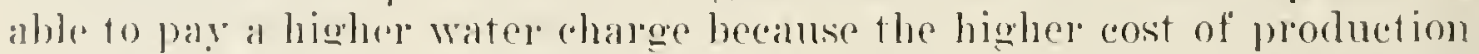
may be due to hetter farming practice which results in better yields. 'These difficultios can not all be given mathematically eorrect weight in the present sturly, becallse the data are not sufficiently eomplete to permit the corrolation. Nor, comsidering that to a large extent estimates ale being dealt with, does this seom necessary for reaching a mactical answer to the unestion muder consideration. "The endeavor has been made to meet these diffieulties by usine costs of production which seem to repuresent good practice. Although tromed "average" costs in the peport, they are not always strietly the arithmetical arerage of the individual records nsed, becanse personal judgment has influenced choice of the costs decided on as eorrect for use in this sturly.

It might be arened that permissible irrigation elanges based on costs of production muder "wood practice." Whether these costs are the

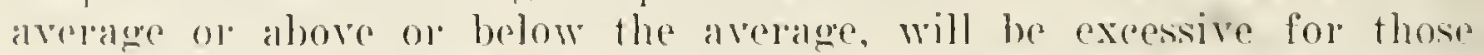
whose costs alre higher. According to this thought, for instance. if the costs used were the median of the reeords studied and farm ineome,

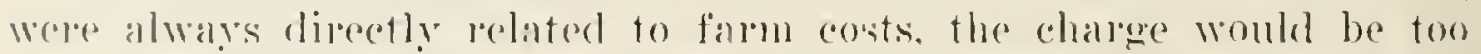
hien lom half of the fallmels. 'The point is. however, that costs" of production and falmo ineome alre not always directly robated. Higher

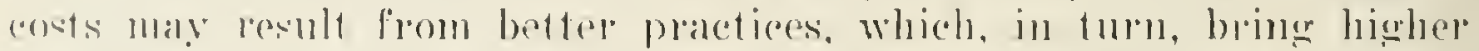
rielis. On the other hand. lower production costs, becaluse some important operation has beren oliminated of entailed. may reduee the

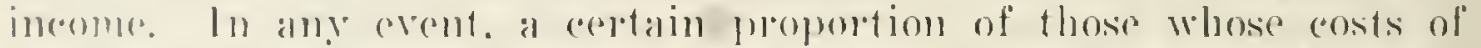

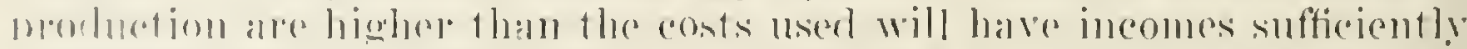

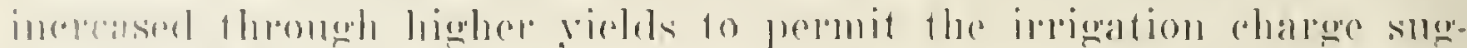

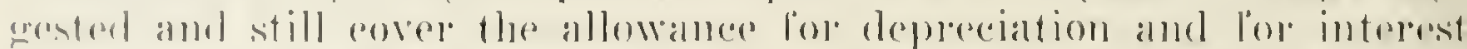

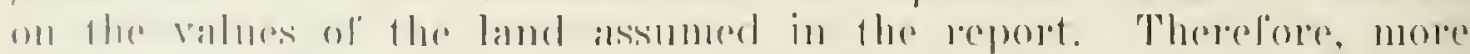

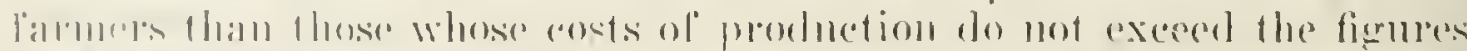

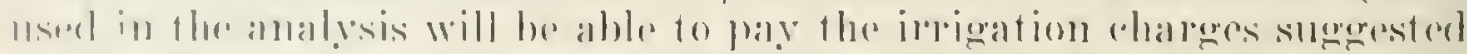
withoult halrelship.

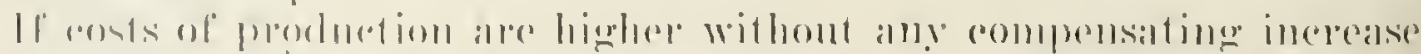

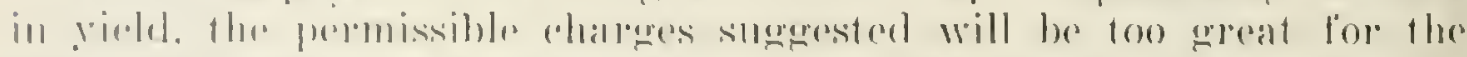

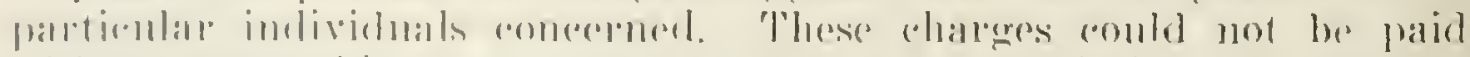

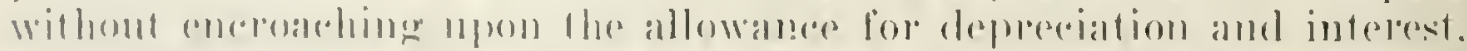

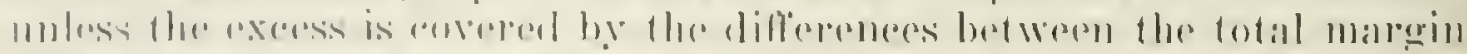

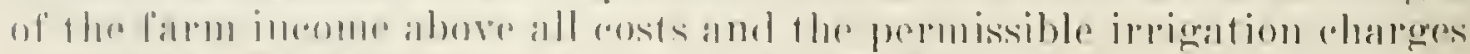

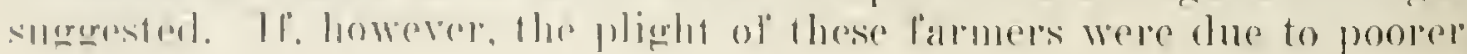




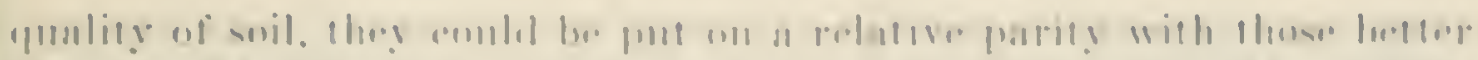

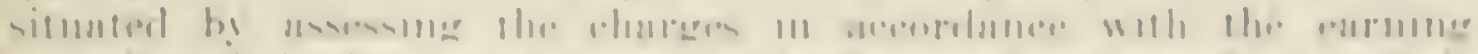

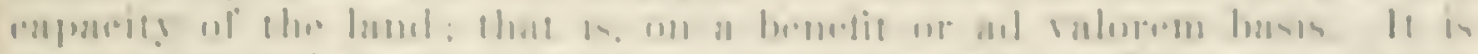

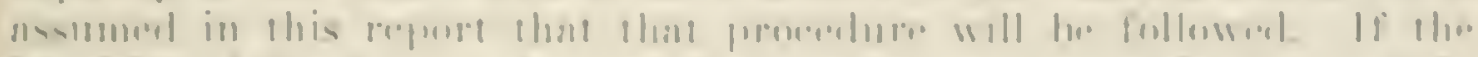

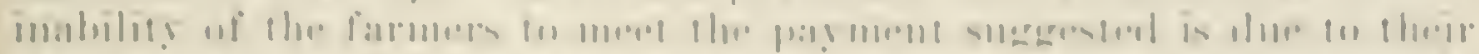

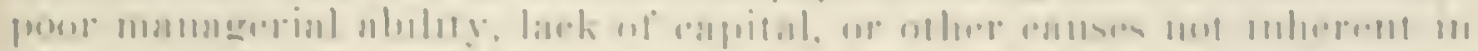

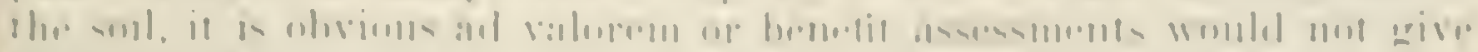
hlo.נn polinel

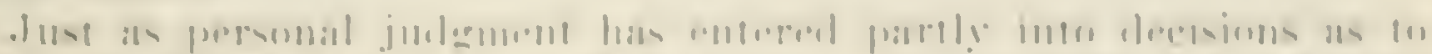

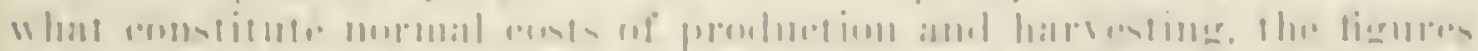

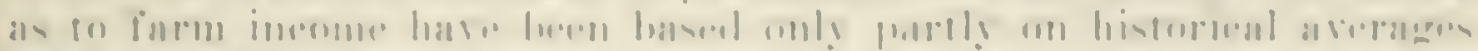

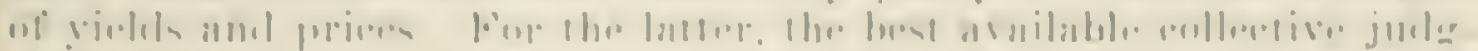
mos!

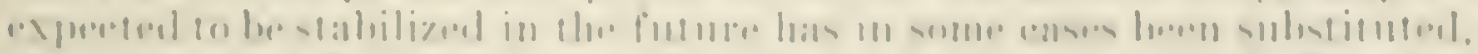

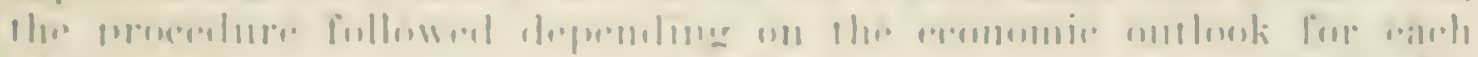

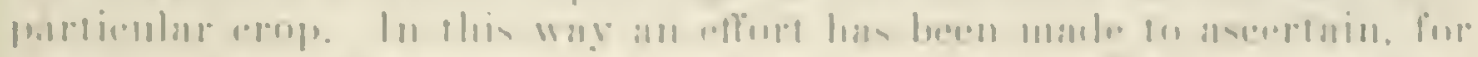

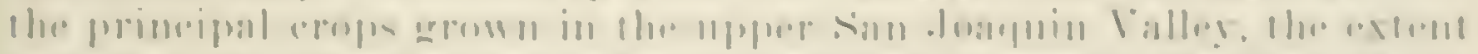

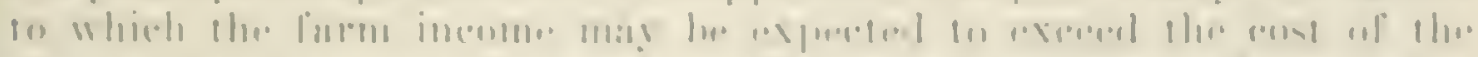

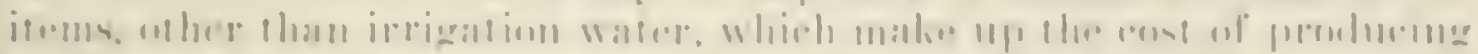

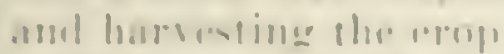

Hheiomsle, all of this .

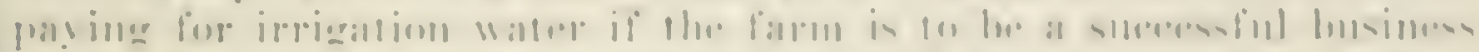

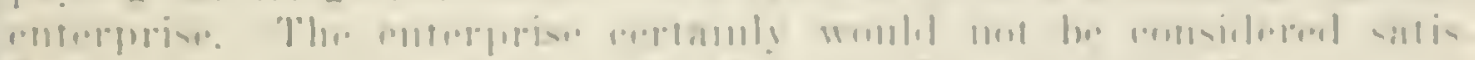

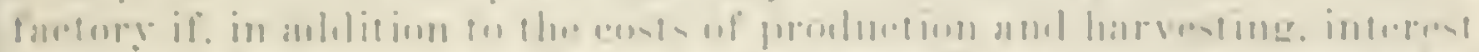

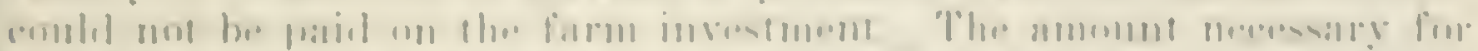

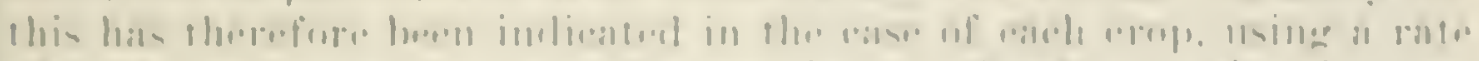

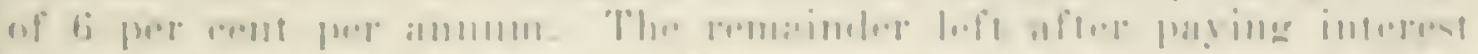

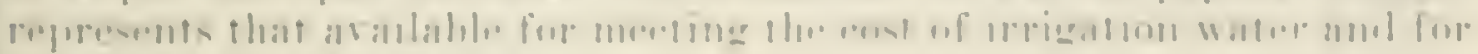
profic alome interent.

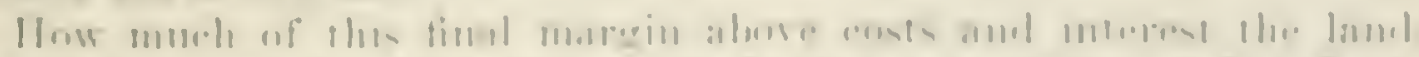

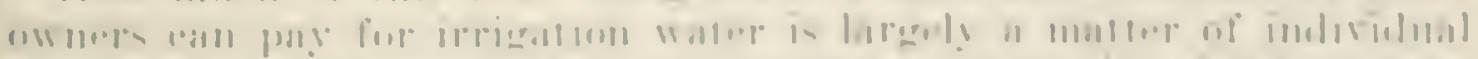

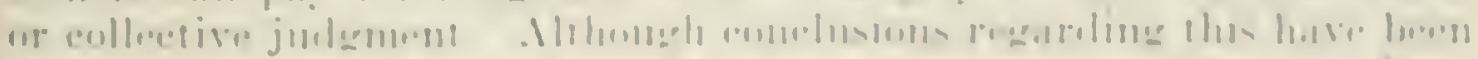

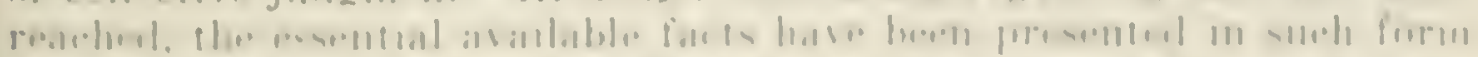

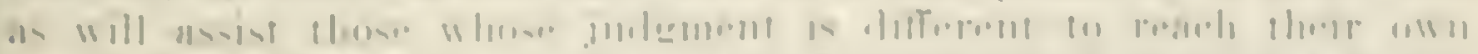

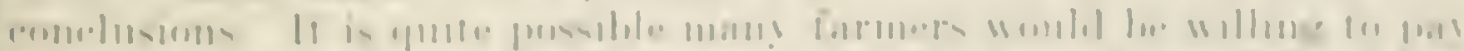

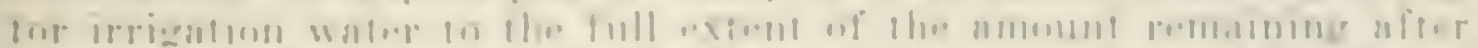

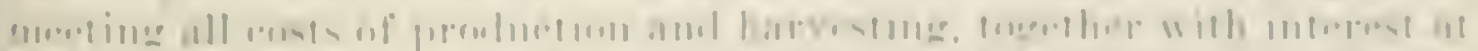

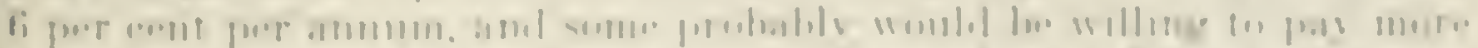

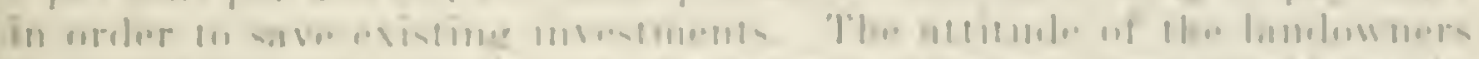

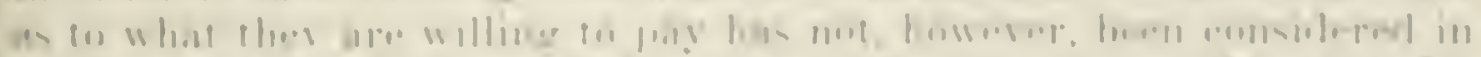

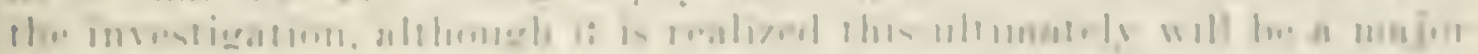

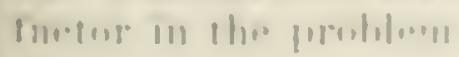

\section{Procedure in Gathering Data}

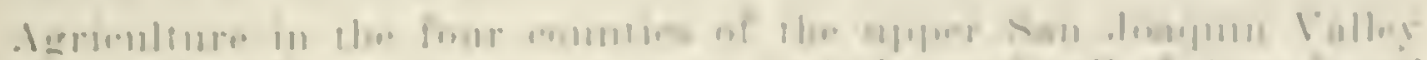

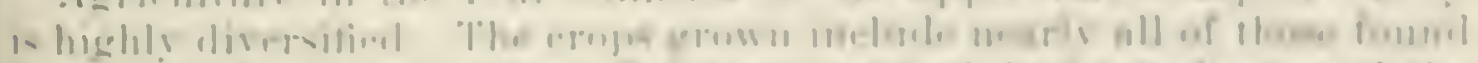

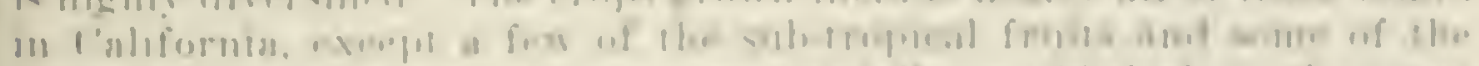

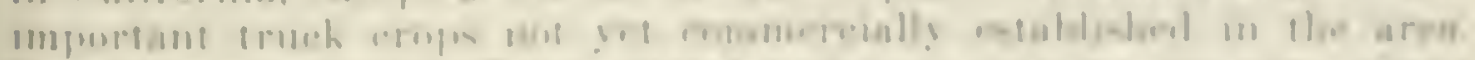

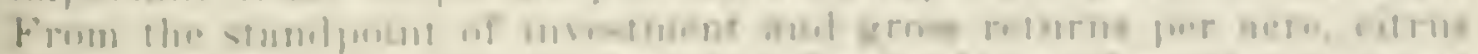

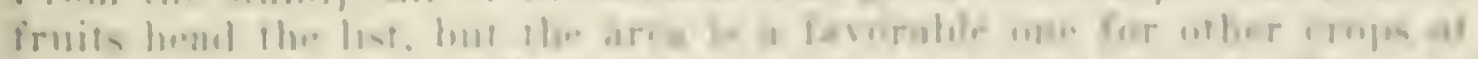

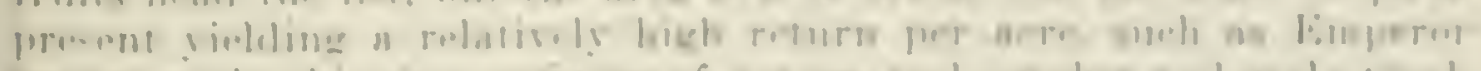

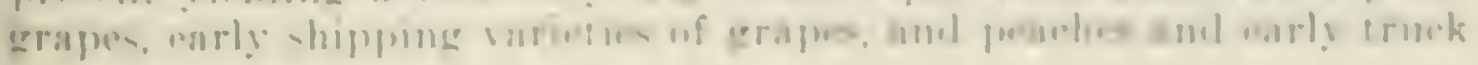


crops. Along with these crops, ol course, go others generally yelding " lower eross jucome. such as the mole common varieties of grapes, deceduous fluits, alfalla, cottom, grain, and miscellaneous field erops.

'The first step in the present study was to assemble or gather for the more representative or more important crops grown in the areas the following data:

1. C'ost of producing and harvesting the erop, not including the eost of irrigation water or interest on the farm investment.

2. The usual lange of yold and price.

3. Present irrigation water costs, including both guraty and pmomped stiplplies.

4. 'The aeneral ataptability of the cupep to the lands of the area, and the ontlook.

Costs of Production.-These have been obtained most largely from the Agricultural Extension Serviee of the College of Agriculture. but also from the Farm Management Section of the College of Agriculture ind direetly from a lan'ere number of erowers; also, in the case of citrus fruits, from the California C'itrus League. Tufolmation obtained from the Agricultural Extension service was anthered by the comnty farm alvisoms in romnection with their enteruntise efficiency studies.

In eollecting theje reconds the eomity falm alvisols selected grower cooperators whom they supplied with the necessary blanks and who submitted montly y reports of all eosts for both labor and materials. The data in these records have been retabulated in older to eliminate interest on the investment and costs of irrigation water, the latter inchuling assessments, watel tolls, interest and depureciation on pumping equipment, or one or more of these items.

Information smpplied by the Fam Management Section is in the formu of gesleral fionrese and represents its conchusions as to production rosts from long observation and field study. 'The material supplied by

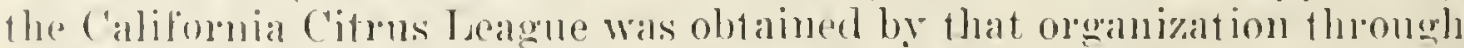
pelsonal interviews with growers over a four-your period.

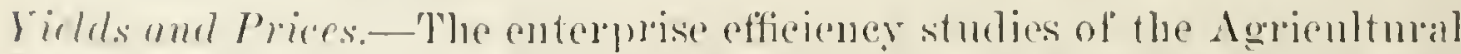

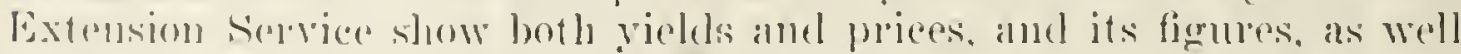
as others gathered foom packing houses and other somees, have been

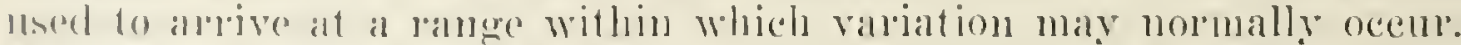
Ther langes talien into consieleration in this report to not include either

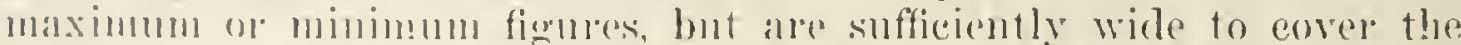

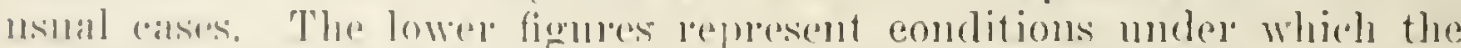

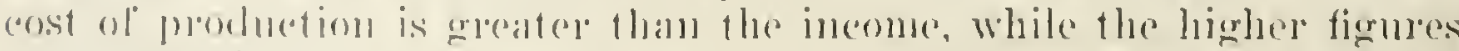

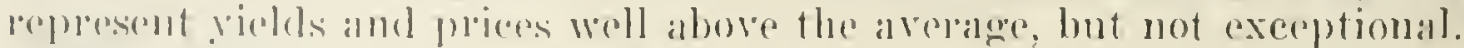

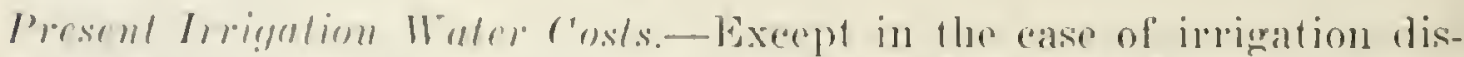
fricels. lor which inlomation is on file in the oftice ol the State Engineer,

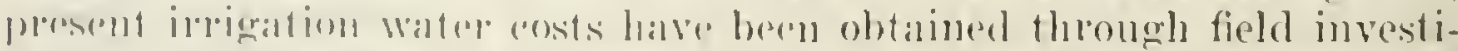

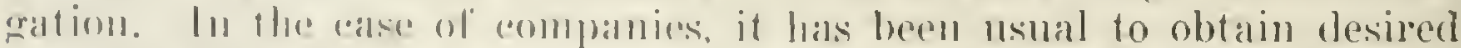

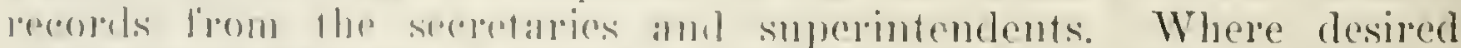
inlempation was not on perentel in the office of the eompanies, the best

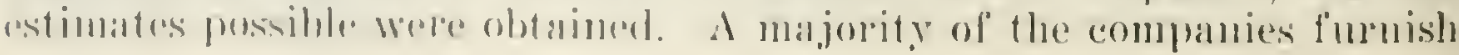




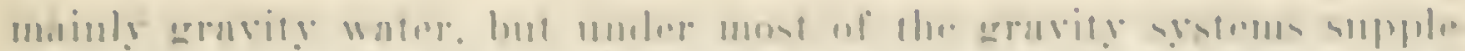

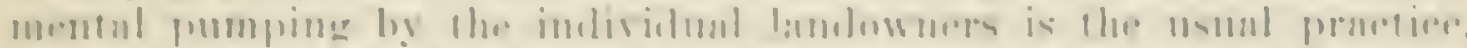

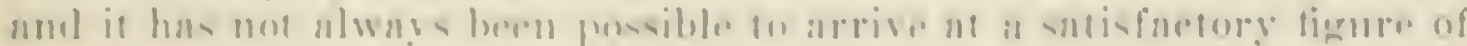

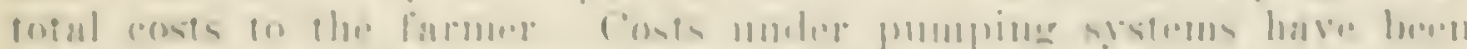

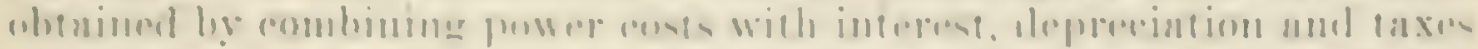

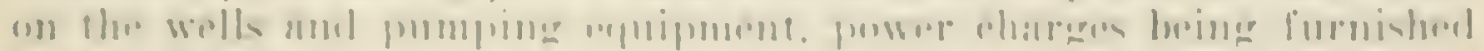

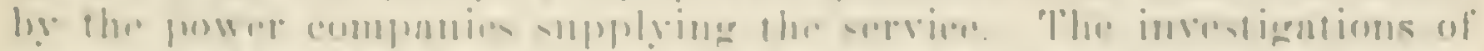

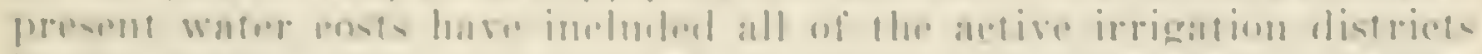

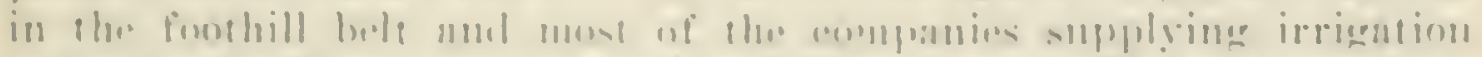

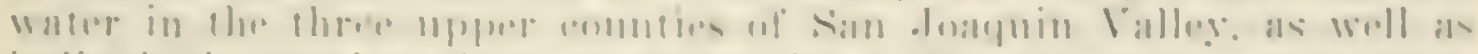

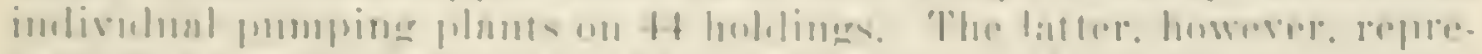

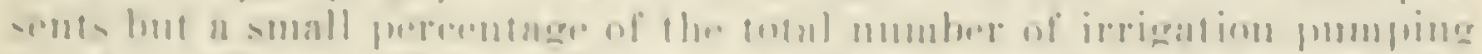

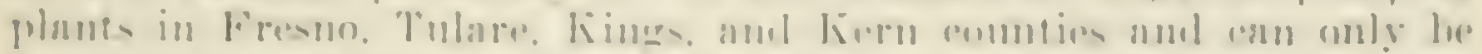

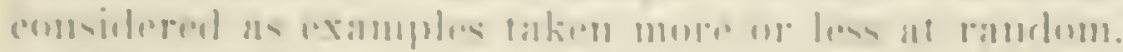

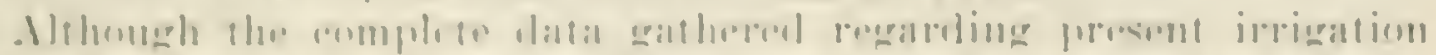

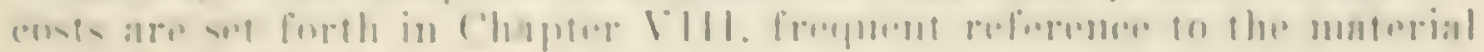

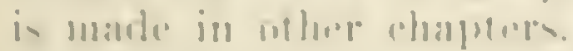

\section{Bas on Which Costs of Production Have Been Computed.}

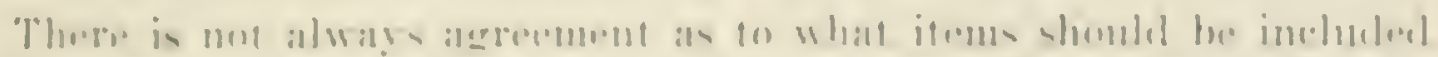

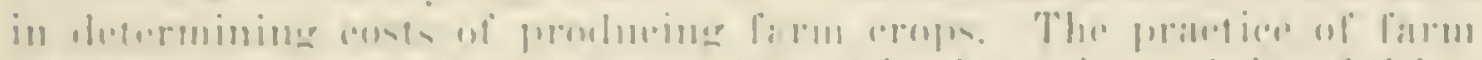

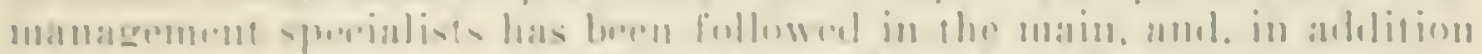

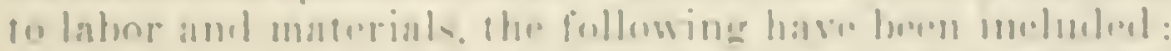

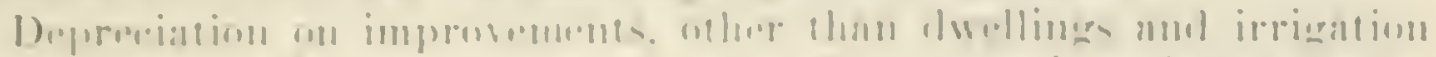

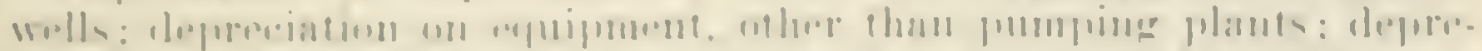

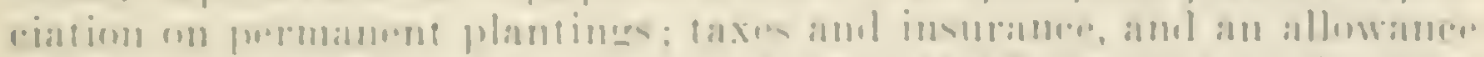

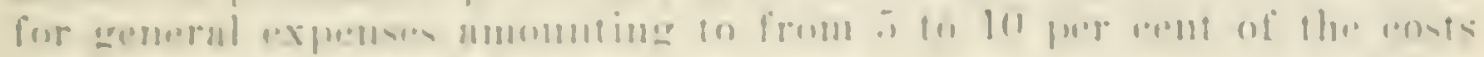
of all lalure and malerials monl.

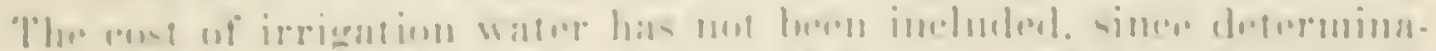

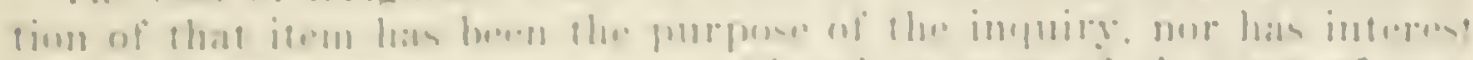

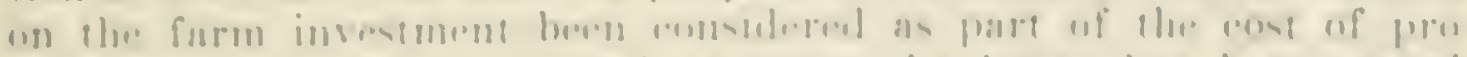

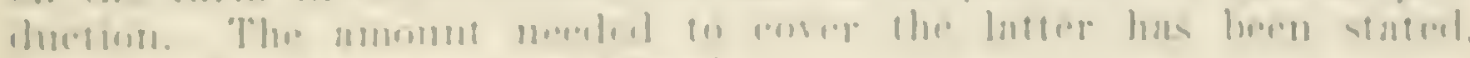

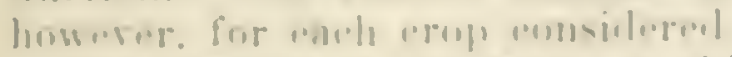

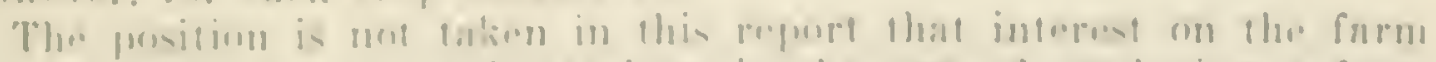

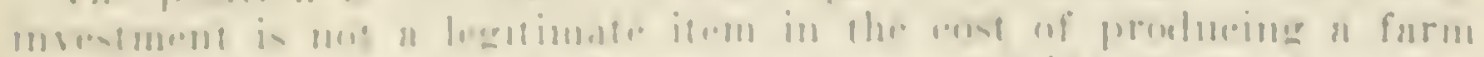

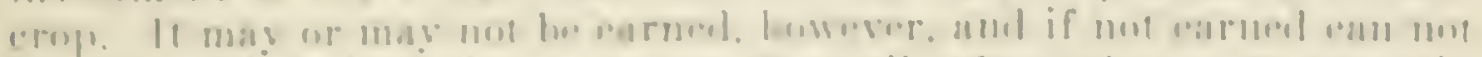

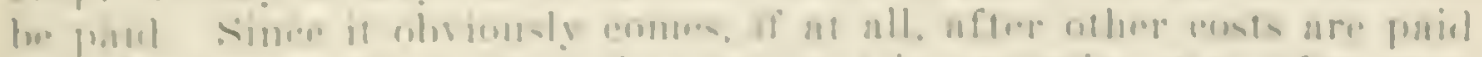

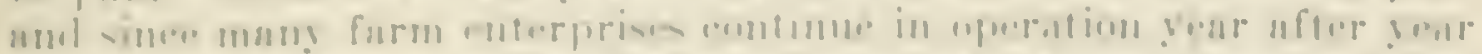

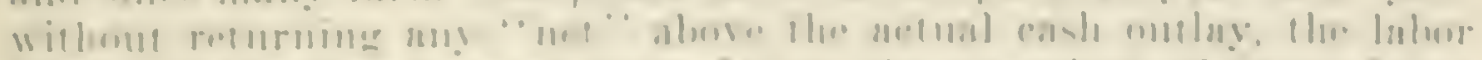

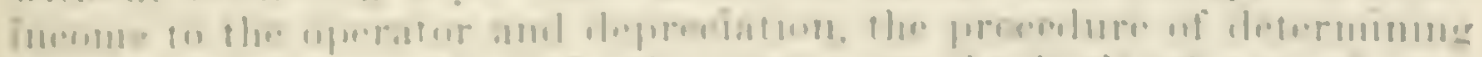

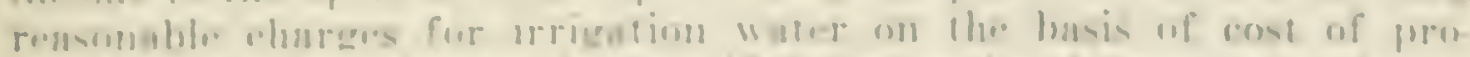

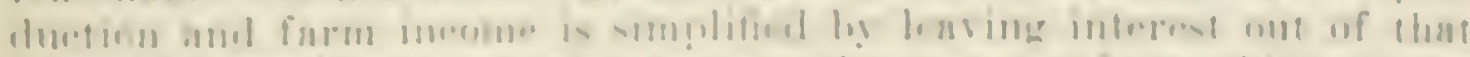

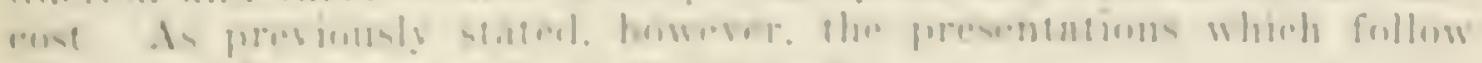

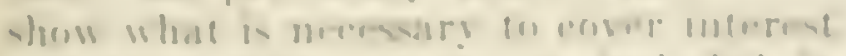

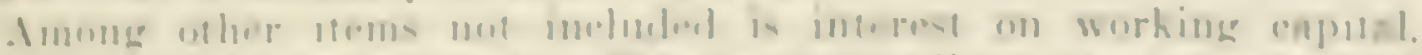

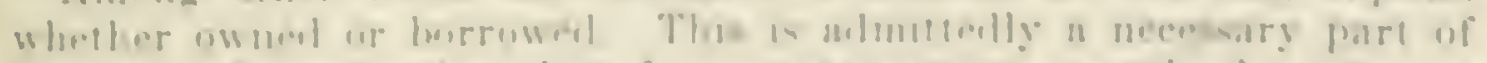

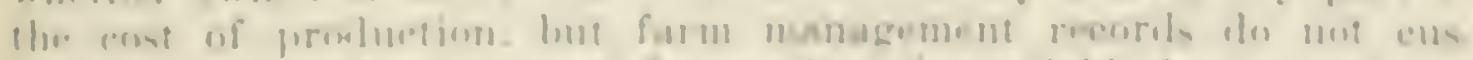

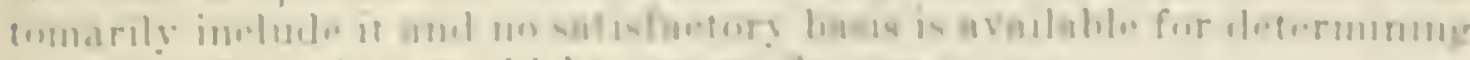

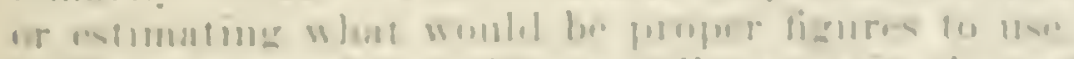

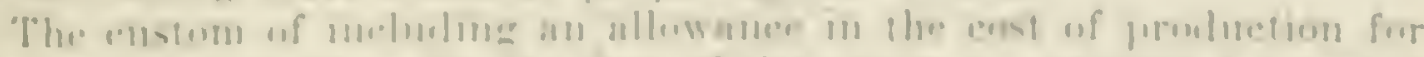

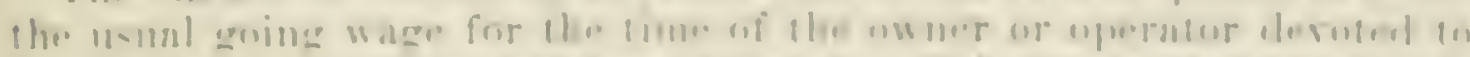

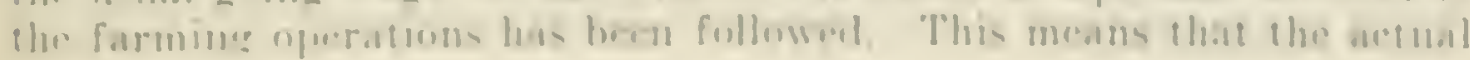


cash outlay may be less than the cost given. No allowance has been made for superintendence by the individual farme operator, the inchusion ol this not heing mstal in such sturlies.

The rate of depreceiation ol plantings is an item on which there is not always an aylerement anong students of form manacement. The Agri-

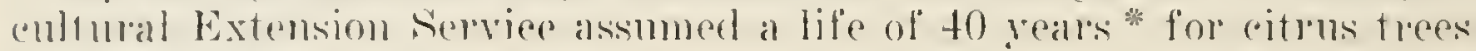

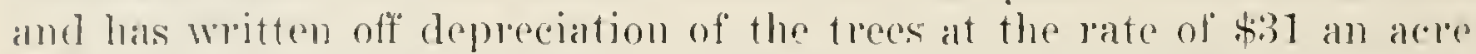

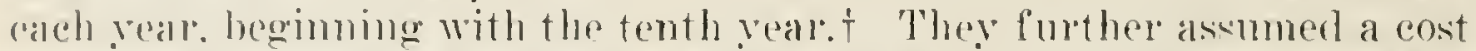
of appoxinately $\$ 1,000$ an acre, exclus ofe of had, for bringing a citrus erove to tell yeals of age, this beine the not cost alter crediting income. These fignles latro been acerpted in this study of reasomable irrigation charese for citros fruits in the mpper San . Joanuin Valley, althongh it is known that in some cases the life of citrus eroves is considerably more or less than 40 real's and that there is comsiderable valuation in the enst of erowing the tress. Depreciation of citrus trees at the rate

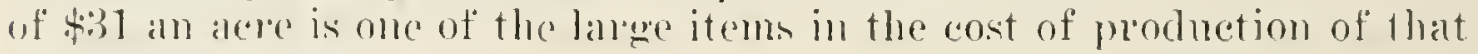
crop and in practice might not be justified.

Depreciation of improvements and expipment has been computed by the farm atrisors baterely on the basis of the ownerse estimates of mesent value and length of life. Their figures have been aceepted for their reeords. Where costs have been determined thromeh direct contact with erowers, rather than from data gathered by others. deprecialtion has been computed at the following rates:

Buildings. is per cent; irrigation pipelines, 4 per eent. and farm opuipument, 15 pereent.

This repolt of eourse is not directly coneerned with farm profits, exceptine as interest may be comsindered in that rategory, as it is by some. and exeepting as they determine broadly the ecomomic eondition of ally particular branch of agriculture and thus fix the general seale

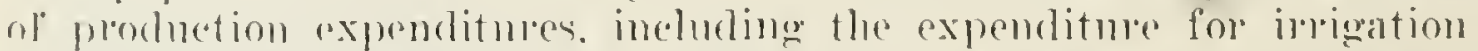
water. Incelentally, howevel, tho tables and charts which lollow are

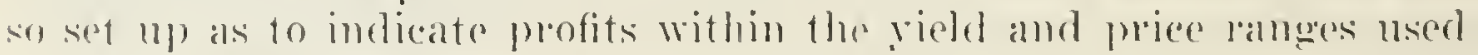
when income is larege enomgh to return a profit.

\section{Correlation of Cost of Irrigation Water With Other Production Costs.}

While it has mot been ustlal in acomomice and engineoring studies to

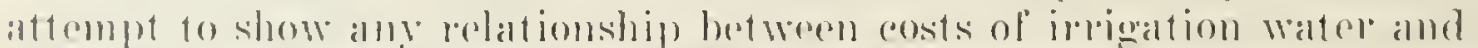

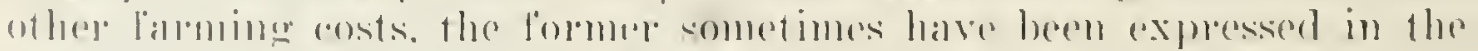

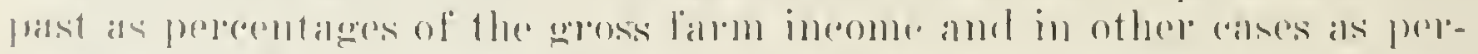

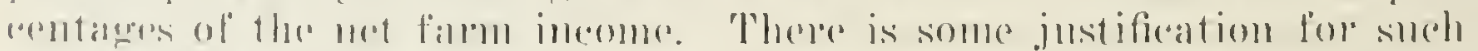

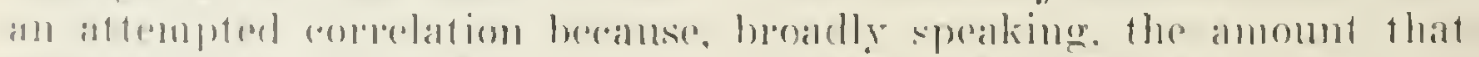

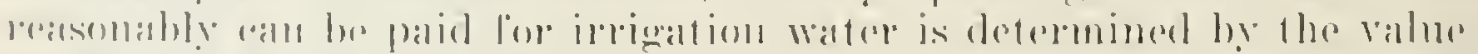

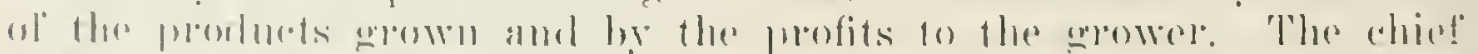

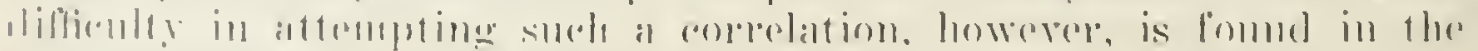

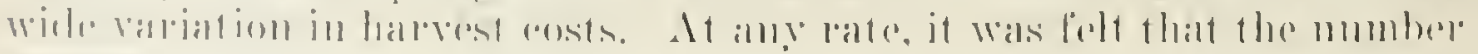

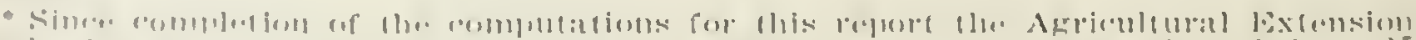

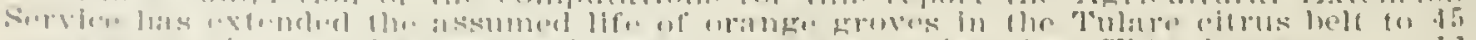

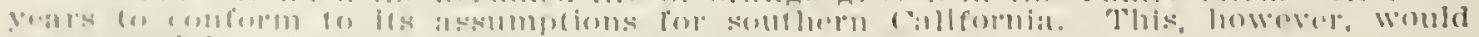

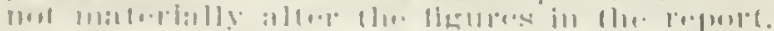

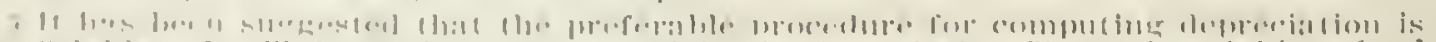

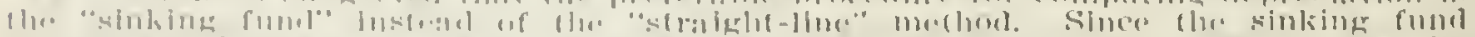

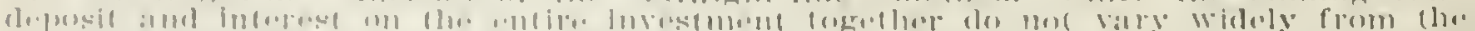

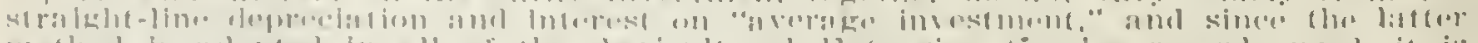

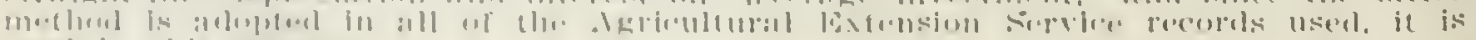

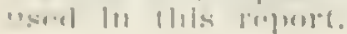


of .

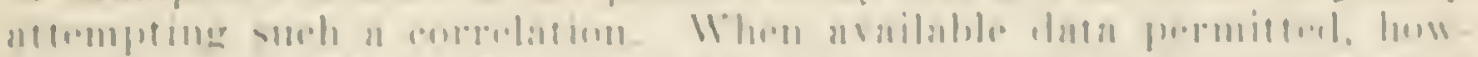

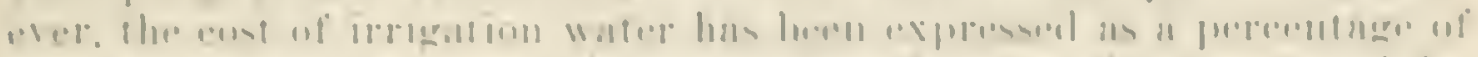
fro.har

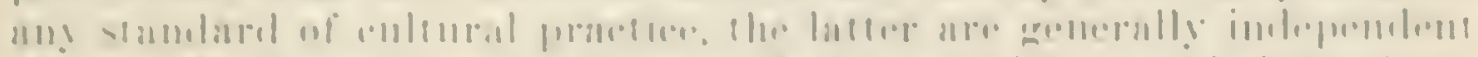

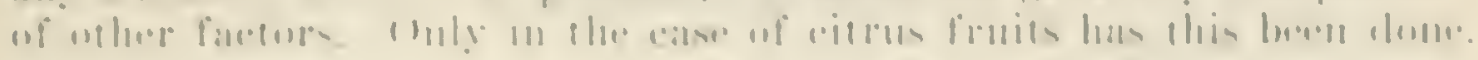

\section{Crops Considered in the Study.}

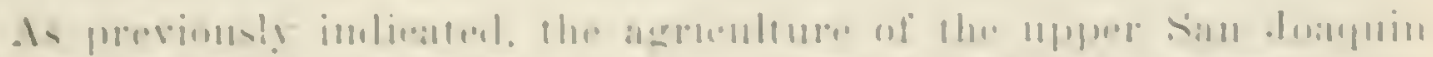

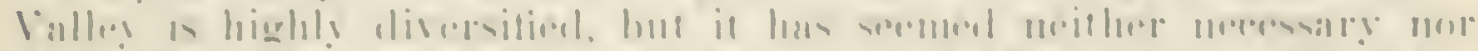

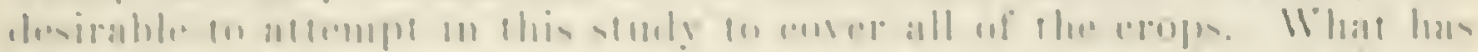

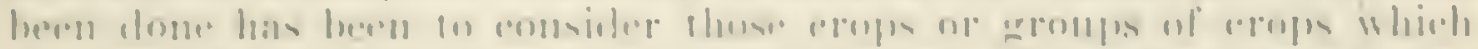

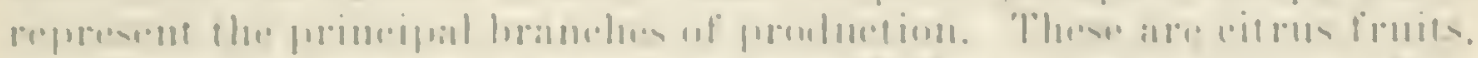

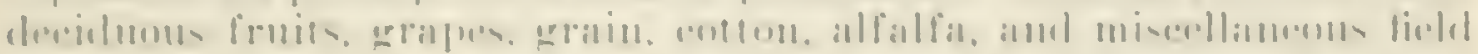
('r)ाp?. 


\section{CIIAP'TER III}

\section{Costs of Production.}

\section{CITRUS FRUITS}

'Thu eitrus area of the Sin .Joaguin Valley, generally referred to as the interior citrus area or the Tulare citrus belt, extends south along the astern plains and fonthills from the vicinity of Kings River through Fresuno, Tulare, and Kern counties to Edison, a few miles east of Billielsfield, and out onto the ralley floor in Fresno County near Dimuba and Reedley. The citrus belt is not continuous, excepting most of tho way along the belt in Tulare County. The present study covered groves near Orange Cove and Reedley in Fresno Comty; near Exeter. Lindsay, strathmore, Porterville. 'Terra Bella, and Ducor in 'Tulare Comnty, and at Edison in Kern Comnty.

Including fourteen costof-production records prepared by the assistant farm atrisor of Tulare Comnty. data rere obtained directly from 22 individual groves and one gloup of groves containing 129 acres. 'The total alea represented by these 23 recolds was 504 acres. of which 2.50 acres were in Washington Navol olanges, 12.) acres in Valencias. and 129 in Narels and Valencias, unservegated. This is, of course. only a small pereentage of the total citrus area in the San .Joaquin Valley. In addition, a four-year record was supplied by the California Citpus Leagrue, this covering the cost of production for Navels on apploximately 100 groves, representing an area of from 2500 to 3000 acres each year.

Of the 39.000 acres now in citrus plantings in the Fresuo-Tularekem area, mole than 60 per cent is in Navels and about 30 pel cent in Valencias. Becanse of this preponderance of Navels. and further becanse, for the purposes of this report. differences between production costs of the two varieties do not appear to be significunt. Navels have heen chiefly considered in this sturly and the conchusions leached are hased larecely on that erop. Valencias ontail an additional cost for frost protection which, althomeh considered desirable for Navels to an rextent that will permit prolonging the harvest into the frost season. is not usually practiced with this valobly. However, as will appear latre. the froblency toward partial lrost protection in the Navel areas has influenced the decision as to what may properly be assumed to be the pre-larrest production cost.

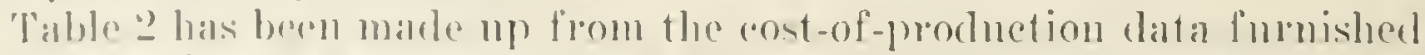
he the assistant liam alvisor of 'Tulate ('omuty or obtained by the

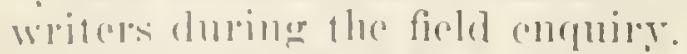

It will he noted that. omitting the recolds for the three latrest ance-

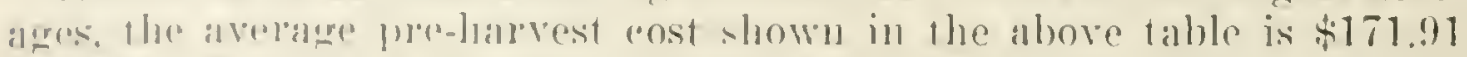

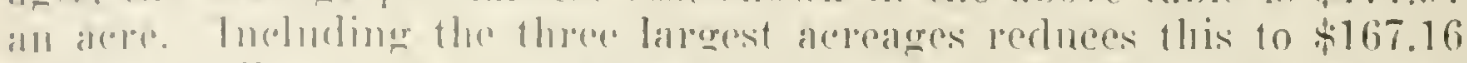

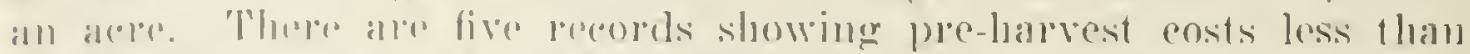

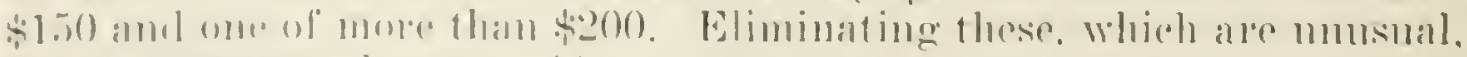

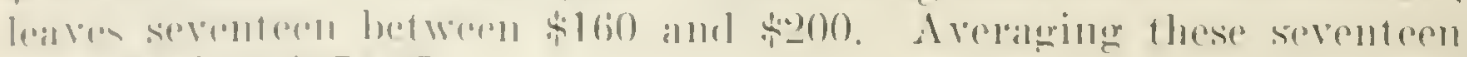

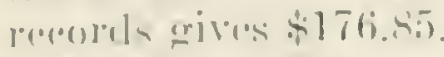

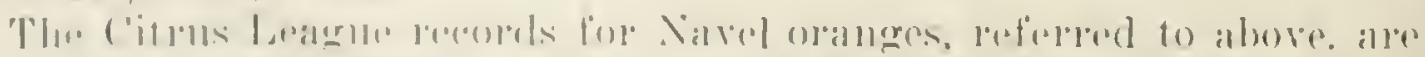

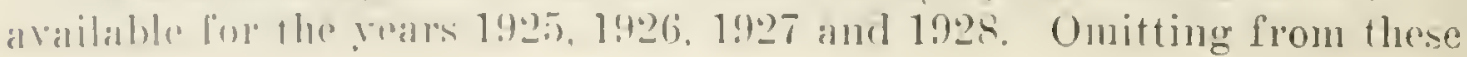




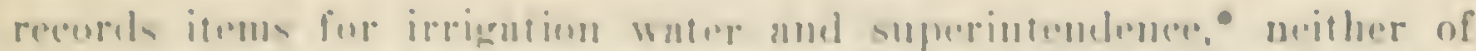

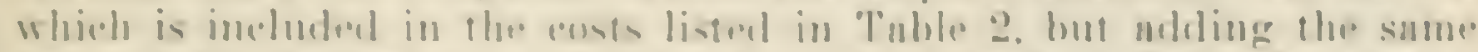

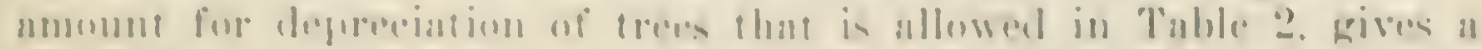

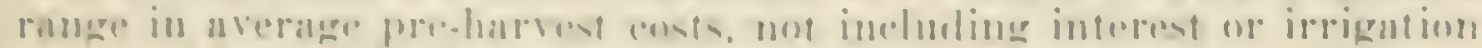

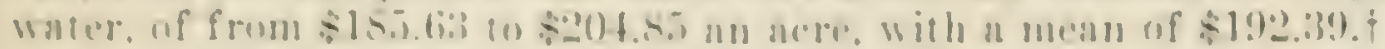

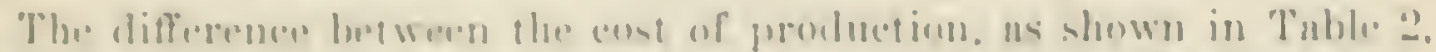

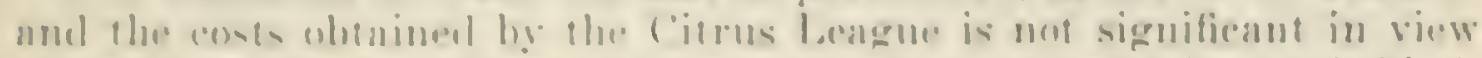

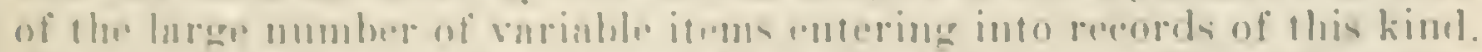

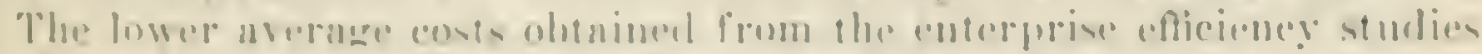

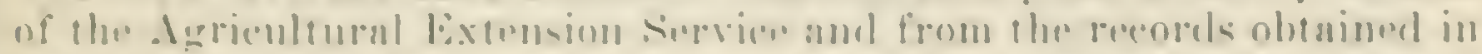

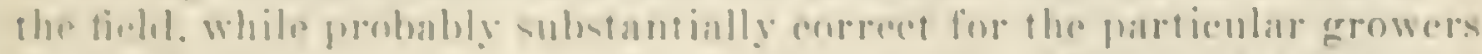

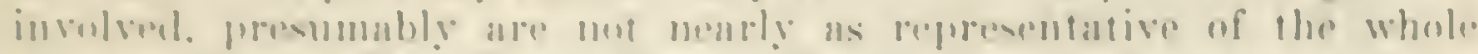

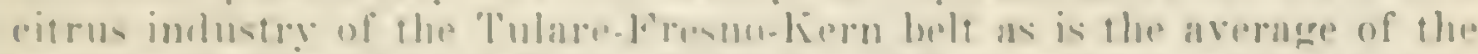

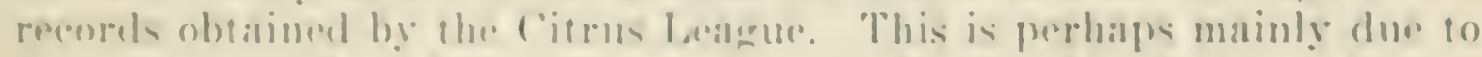

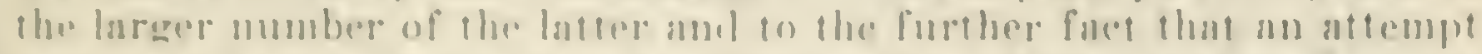

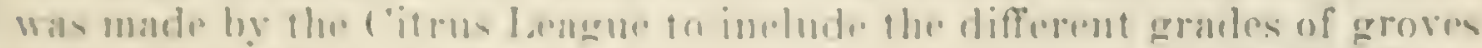

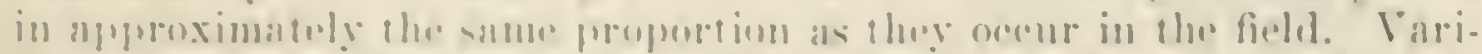

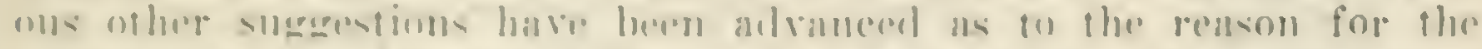

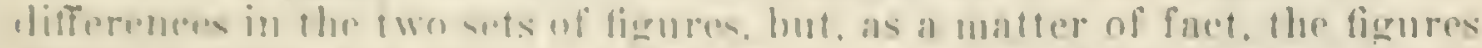

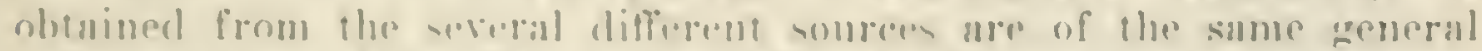

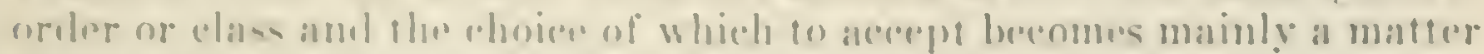

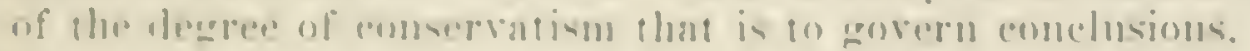

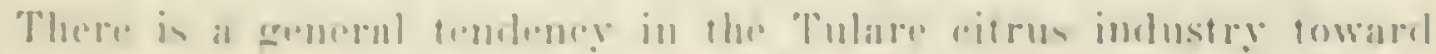

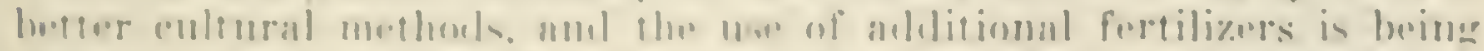

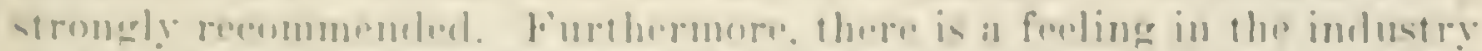

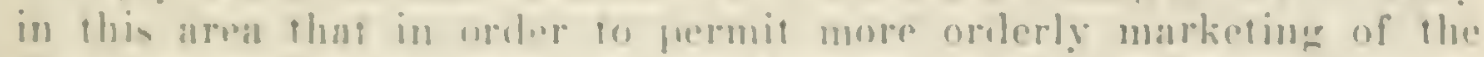

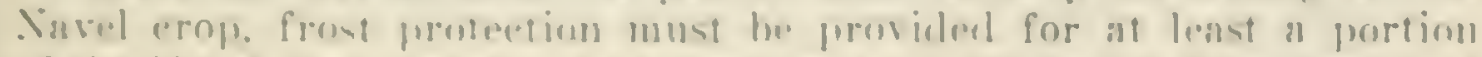

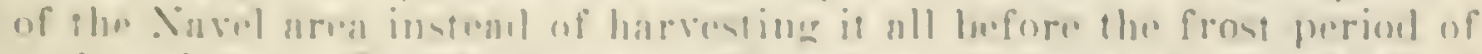

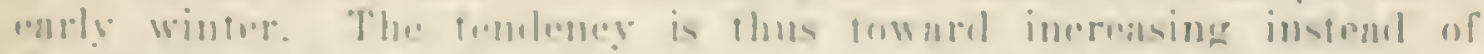

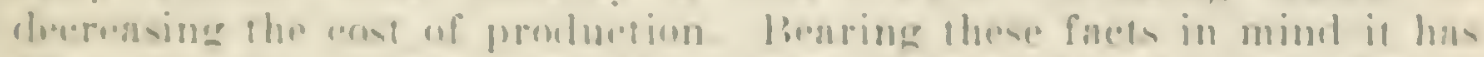

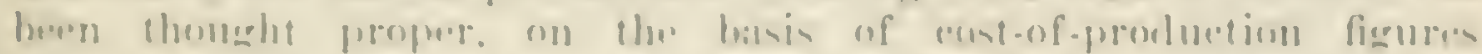

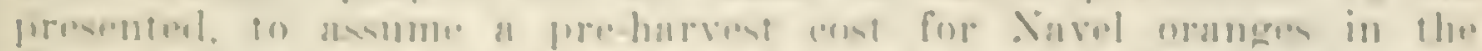

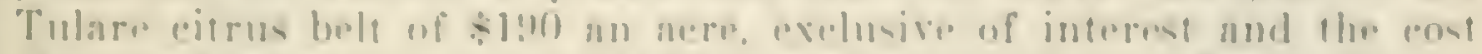

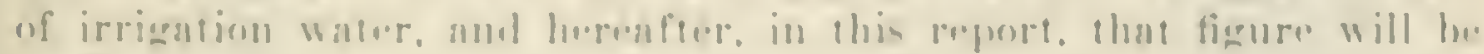
IIserel.

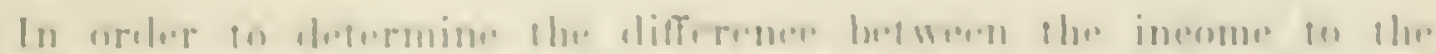

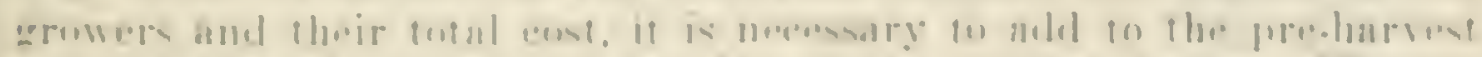

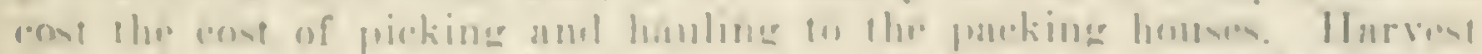

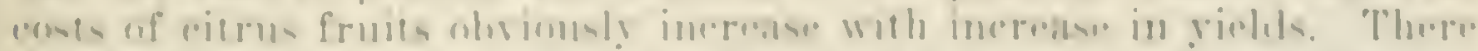

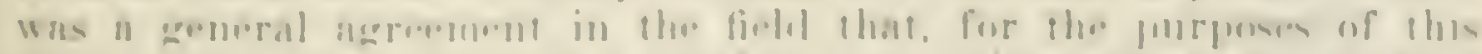

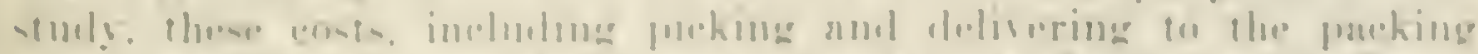

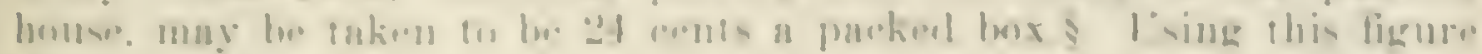

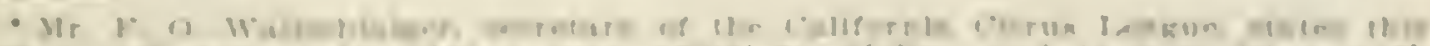

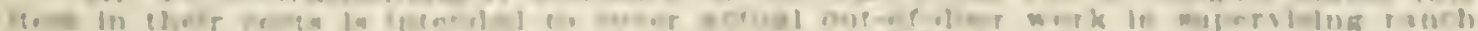

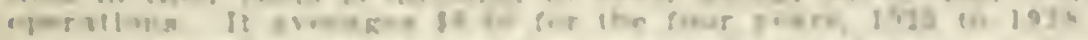

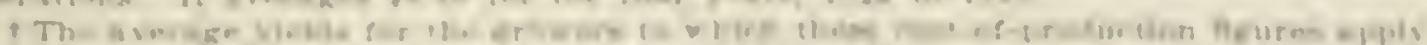

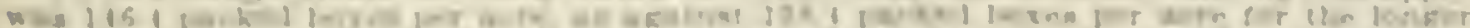

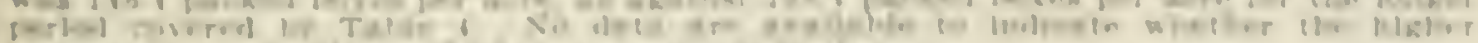

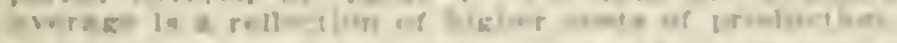

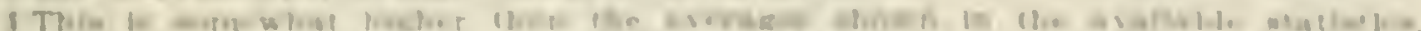

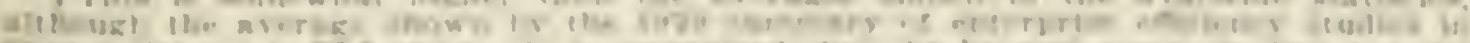

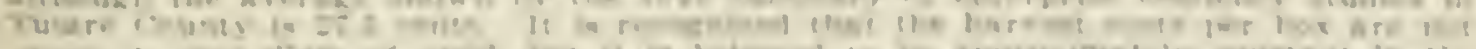

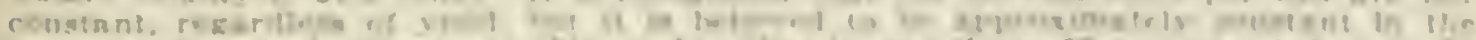

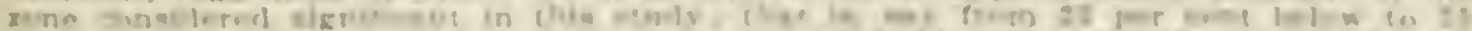

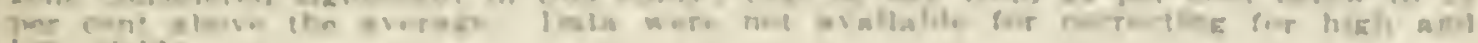
low : In] 10 
alul a

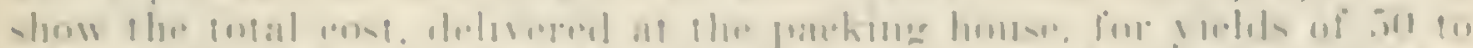

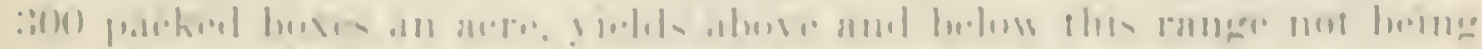

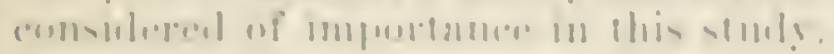

[NII-1 3

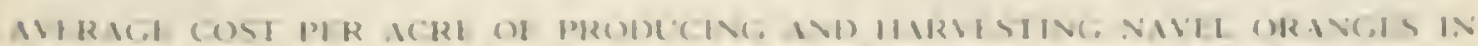

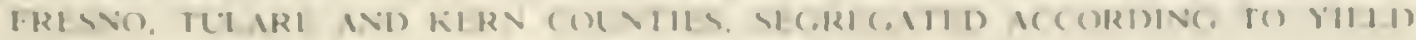

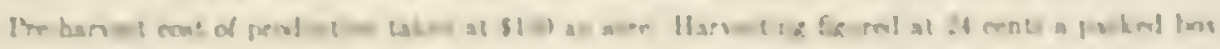

\begin{tabular}{|c|c|c|c|}
\hline$y=b i$ rook nl & $10+8=10$ & 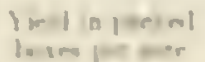 & 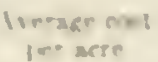 \\
\hline $\begin{array}{l}51 \\
\text { is } \\
111 \\
1 \geq 3 \\
130 \\
103\end{array}$ & 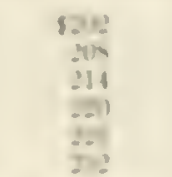 & 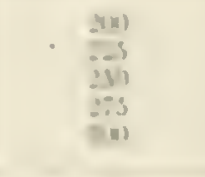 & 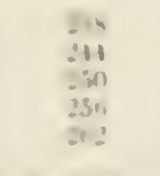 \\
\hline
\end{tabular}

\section{Yields and Prices of Navel Oranges.}

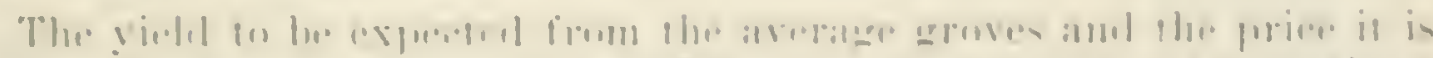

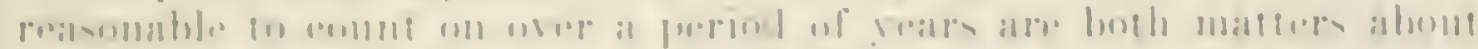

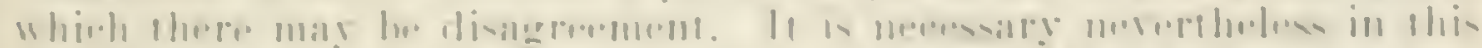

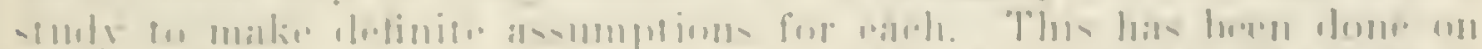

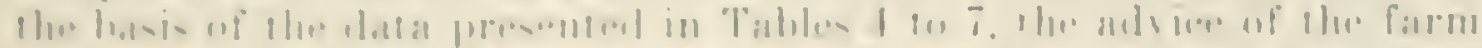

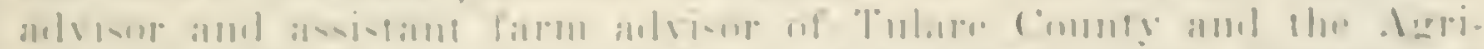

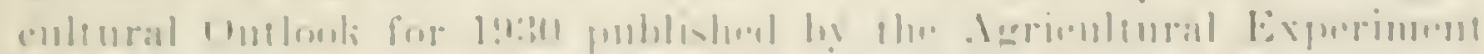
Pillinill.

$1 \mid 311+$

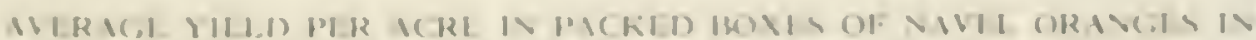

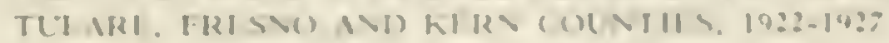

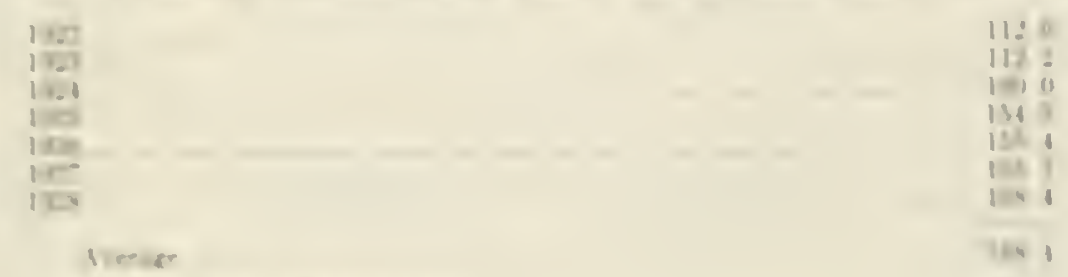

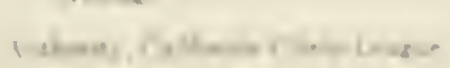

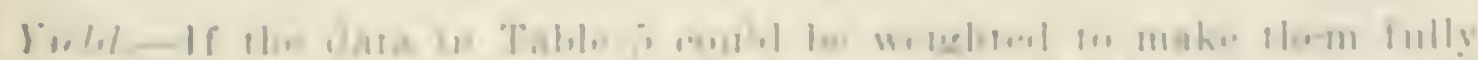

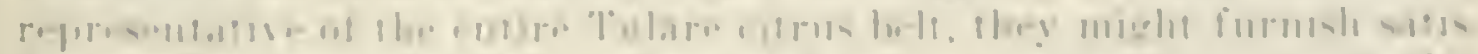

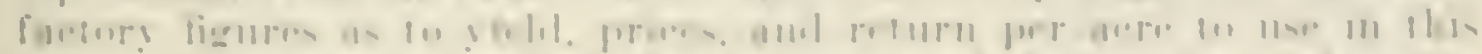

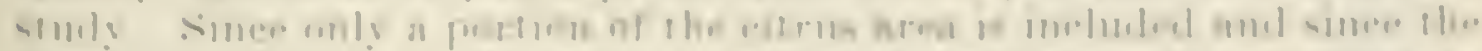

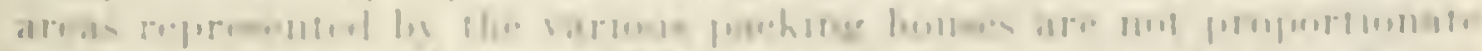

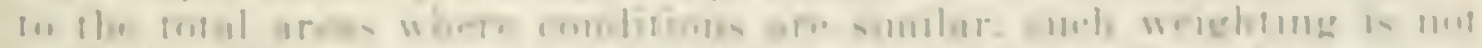

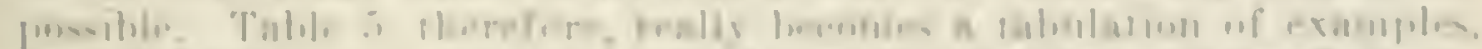

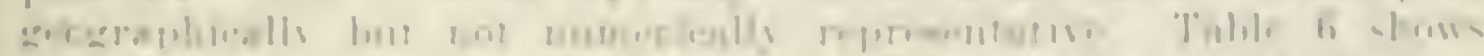

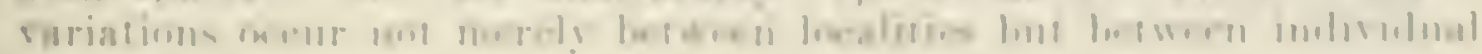
zrus.r.

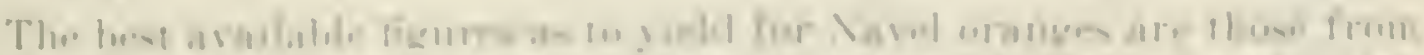

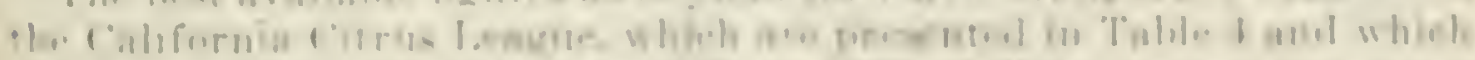

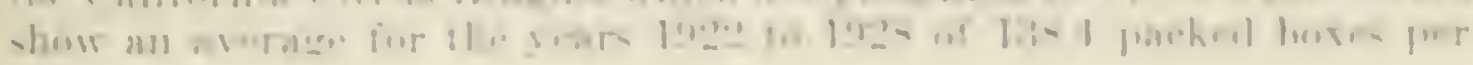



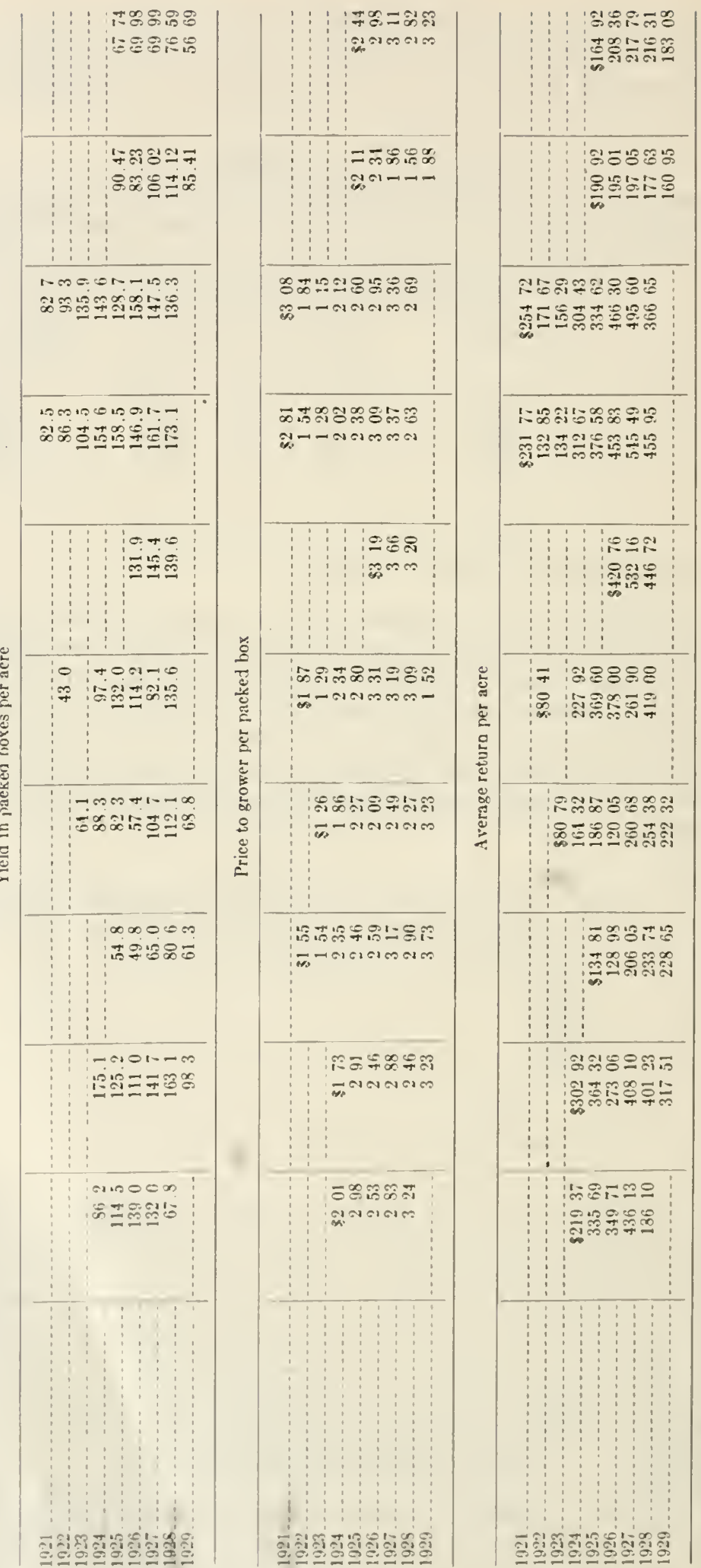
I.MII I

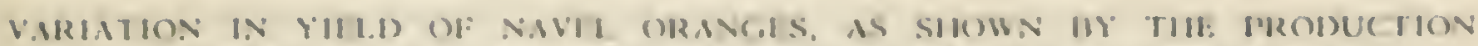

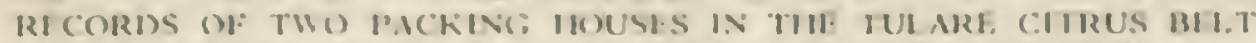

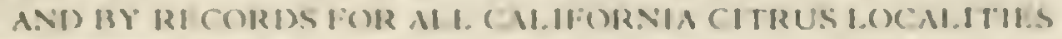

\begin{tabular}{|c|c|c|c|}
\hline 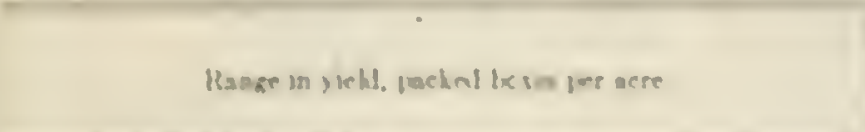 & $\begin{array}{c}\text { Packing houser } \\
\text { bo i } \\
19 \pm:-1 \text { : }\end{array}$ & $\begin{array}{c}\text { Packi a lioume } \\
\text { Jo : } \\
(1925-19 \geq 9)\end{array}$ & $\begin{array}{l}\text { Cin Ifornts } \\
\text { Cierus } \\
\text { Isarue }\end{array}$ \\
\hline 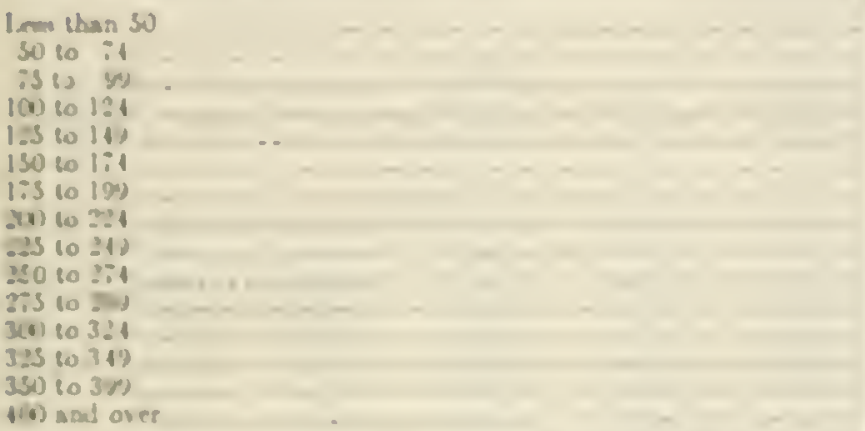 & $\begin{array}{l}3 \\
01 \\
11 \\
10 \\
5 \\
\vdots \\
1 \\
11 \\
0 \\
0 \\
0 \\
0 \\
0 \\
0 \\
0\end{array}$ & $\begin{array}{c}6 \\
13 \\
10 \\
3 \\
\vdots \\
1 \\
\vdots \\
1 \\
2 \\
0 \\
0 \\
11 \\
0 \\
0 \\
0\end{array}$ & $\begin{array}{l}11 \\
25 \\
13 \\
30 \\
61 \\
13 \\
44 \\
15 \\
14 \\
25 \\
21 \\
17 \\
13 \\
12 \\
14\end{array}$ \\
\hline
\end{tabular}

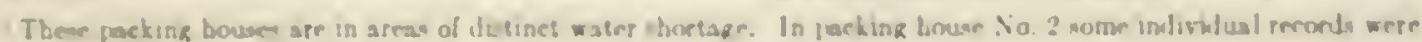
for he ibun the Gieyear in'sicel

leiborib). ('stornas Cilrut laguo

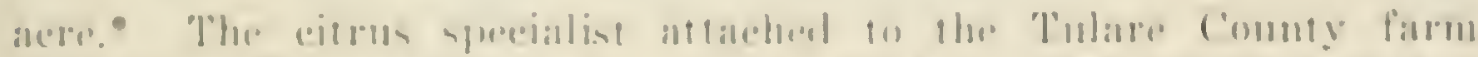

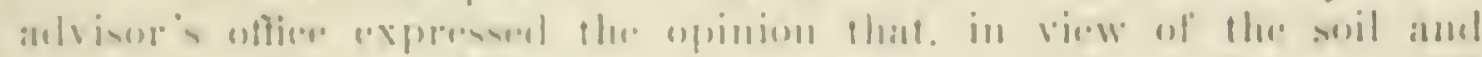

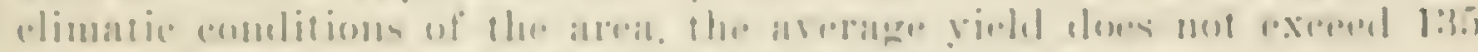

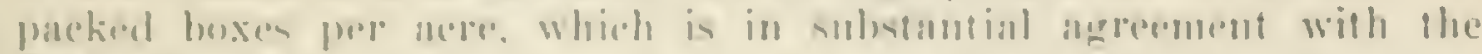
Cirms League abriage.

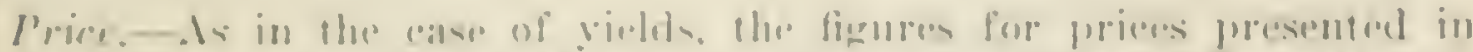

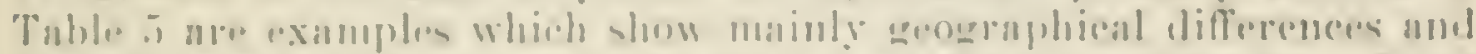

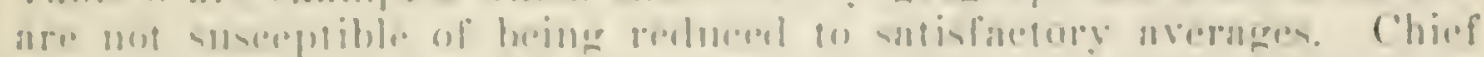

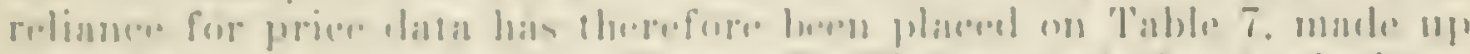

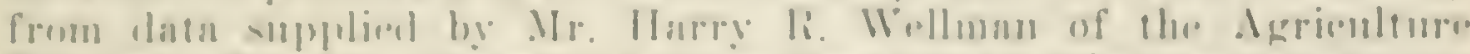

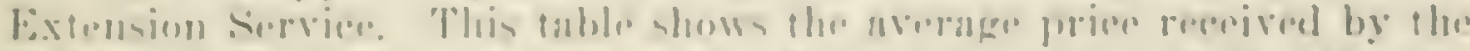

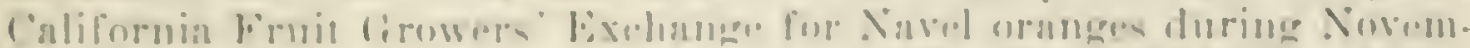

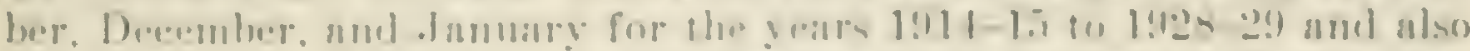

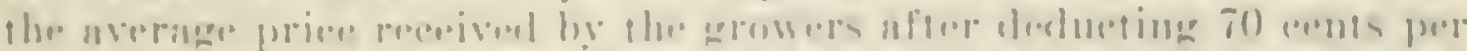

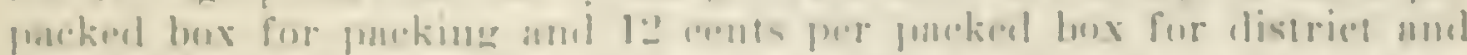

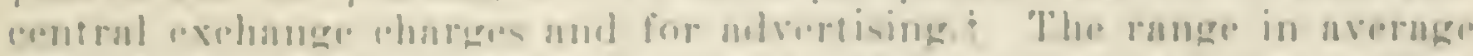

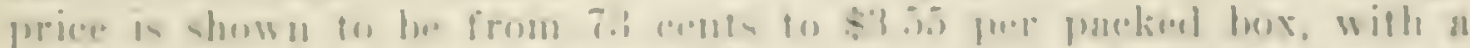

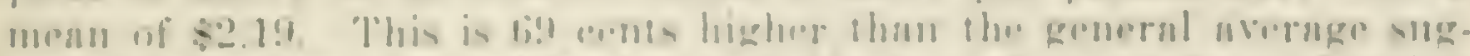

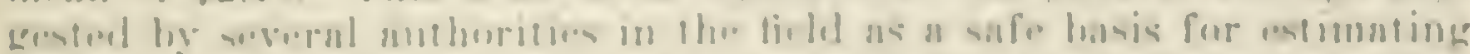

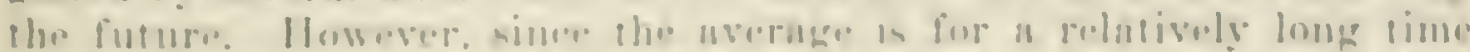

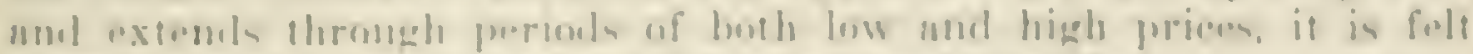

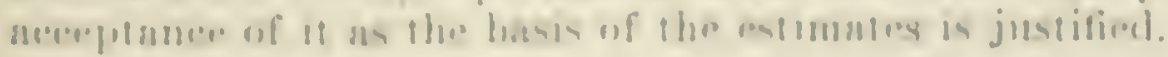

\section{Income to Citrus Growers and Amount Avalable for Water Charges.}

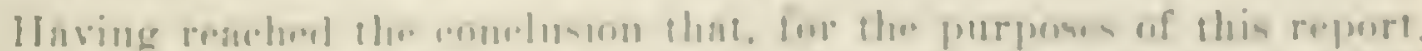

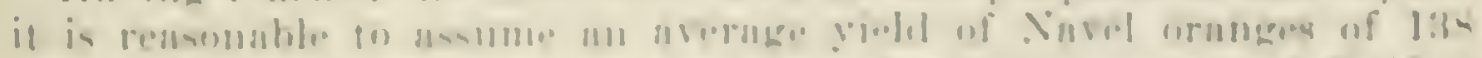

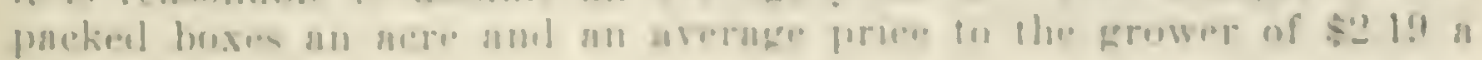

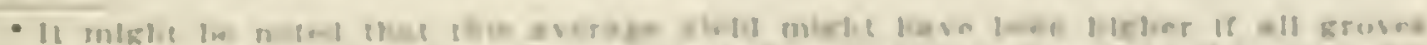

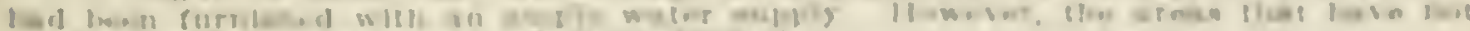

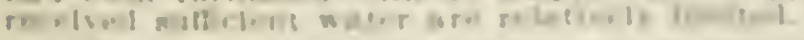

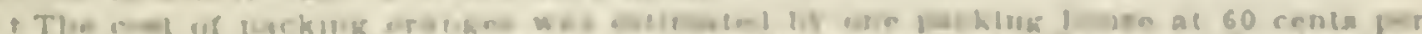

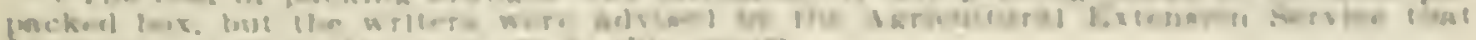

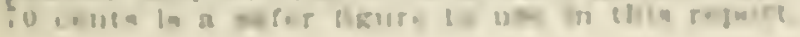


TABLE 7

AVERAGE f.o.b. PRICES PER PACKED BOX RECEIVED FOR NAVEL ORANGES IN TULARE CITRUS BELT BY TIIE CALIFORNIA FRUIT GROWERS EXCIIANGE FOR NOVEMBER, DECEMBER AND JANUARY, 1914-15 TO 1928-29, AND AVERAGE PRICES RECEIVED BY THE GROWERS DURING TIIE SAMIE MONTISS AND YEARS.

After deducting $\$ 2$ cents a packed box to eover packing house, exchange and advertising charges.

\begin{tabular}{|c|c|c|c|c|c|c|c|}
\hline & \multicolumn{3}{|c|}{ F. O. B. to Exchange } & \multicolumn{4}{|c|}{ Priec to growers } \\
\hline & November & December & January & November & December & Janua $y$ & $\begin{array}{l}\text { Average for } \\
\text { Nov.. Dee., } \\
\text { Jan. }\end{array}$ \\
\hline 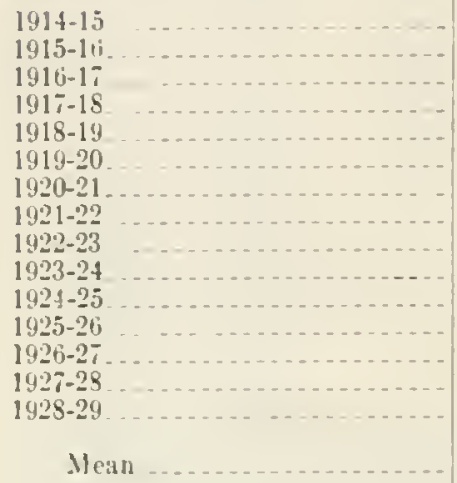 & $\begin{array}{ll}\$ 1 & 97 \\
2 & 70 \\
2 & 28 \\
2 & 51 \\
4 & 06 \\
3 & 32 \\
3 & 56 \\
4 & 20 \\
3 & 08 \\
2 & 50 \\
2 & 99 \\
3 & 99 \\
4 & 31 \\
5 & 18 \\
3 & 72 \\
& \end{array}$ & $\begin{array}{ll}\$ 1 & 34 \\
1 & 71 \\
1 & 49 \\
3 & 25 \\
3 & 59 \\
3 & 27 \\
2 & 39 \\
3 & 36 \\
2 & 63 \\
1 & 99 \\
3 & 32 \\
3 & 11 \\
3 & 49 \\
3 & 97 \\
3 & 53\end{array}$ & $\begin{array}{ll}\$ 1 & 33 \\
1 & 82 \\
1 & 60 \\
3 & 71 \\
3 & 09 \\
3 & 64 \\
2 & 43 \\
3 & 22 \\
2 & 56 \\
2 & 15 \\
3 & 10 \\
3 & 34 \\
3 & 55 \\
3 & 96 \\
3 & 01\end{array}$ & $\begin{array}{ll}51 & 15 \\
1 & 59 \\
1 & 46 \\
1 & 69 \\
3 & 24 \\
2 & 50 \\
2 & 74 \\
3 & 38 \\
2 & 26 \\
1 & 69 \\
2 & 17 \\
3 & 16 \\
3 & 49 \\
4 & 36 \\
2 & 90\end{array}$ & $\begin{array}{ll}80 & 52 \\
0 & 95 \\
0 & 67 \\
2 & 43 \\
2 & 77 \\
2 & 45 \\
1 & 57 \\
2 & 54 \\
1 & 51 \\
1 & 17 \\
2 & 50 \\
2 & 29 \\
2 & 67 \\
3 & 15 \\
2 & 71\end{array}$ & $\begin{array}{ll}50 & 51 \\
1 & 00 \\
0 & 75 \\
2 & 89 \\
2 & 27 \\
2 & 8 ! \\
1 & 61 \\
2 & 40 \\
1 & 74 \\
1 & 33 \\
2 & 28 \\
2 & 52 \\
2 & 67 \\
3 & 14 \\
2 & 19\end{array}$ & $\begin{array}{ll}\$ 0 & 73 \\
1 & 28 \\
0 & 97 \\
2 & 34 \\
2 & 76 \\
2 & 59 \\
1 & 97 \\
2 & 77 \\
1 & 94 \\
1 & 39 \\
2 & 32 \\
2 & 66 \\
2 & 73 \\
3 & 55 \\
2 & 50 \\
\$ 2 & 19\end{array}$ \\
\hline
\end{tabular}

packed box during November. December, and .January, the months of langest shipments, it mow becomes necessary to compute of estimate the income to the growers and the amoment that is avaiblabe for irrigation water. To asisist in this. Tables 8 and 9 and Plate l have been prepared.

Table s shows the income to gromers of Navel oranges with prices

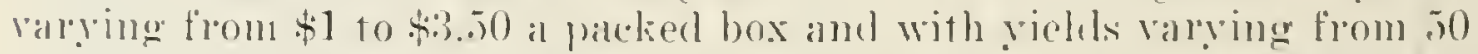
fo 300 palcked boxes an ace. Pable 9 shows the income available for papronent of irrigation water changes. interest on investment, and

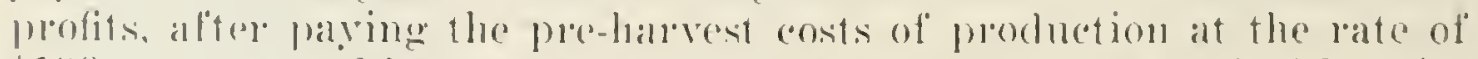

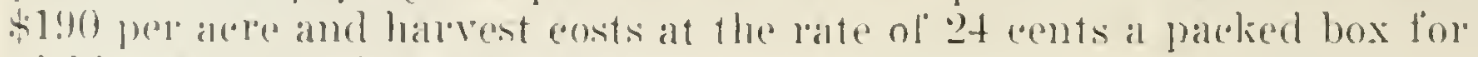
picking and hanling to the palekinu house.

Plate I waphlically presents the ineonle to mowers with varyinger

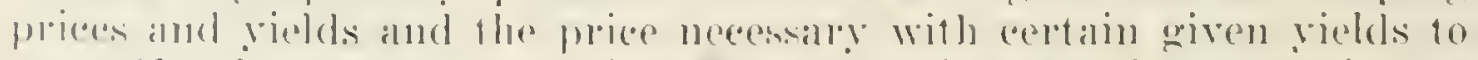

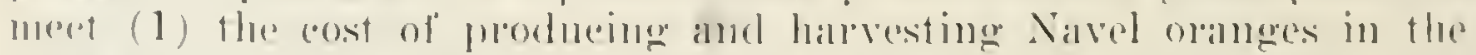

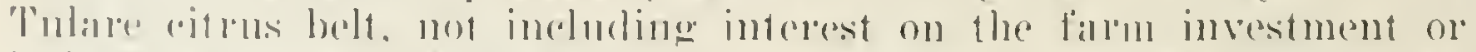

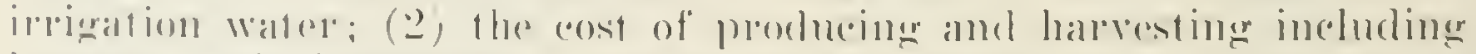

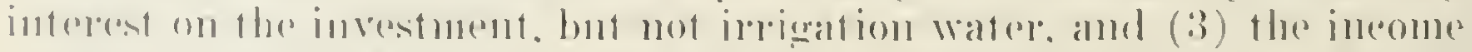
11000

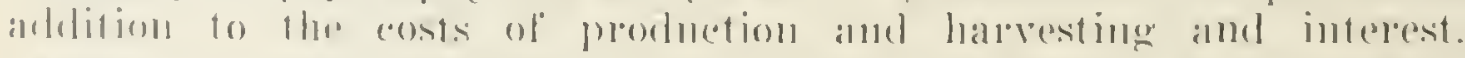

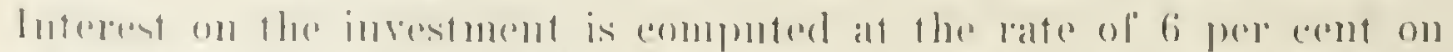

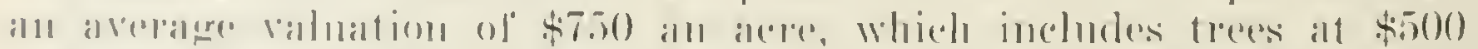

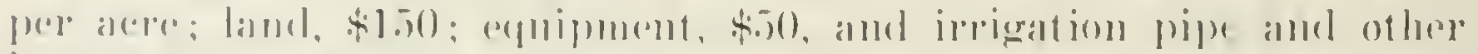

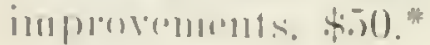

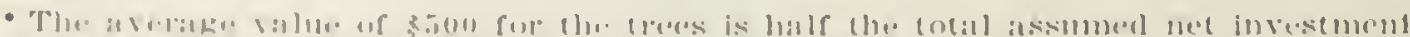

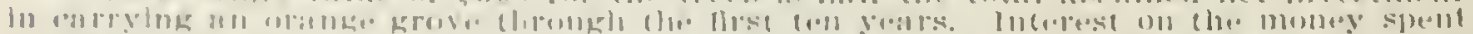

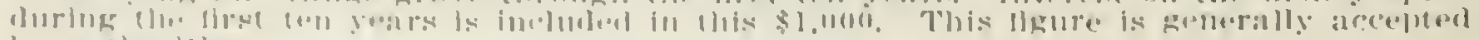
ly: :IIIlorillo.s. 


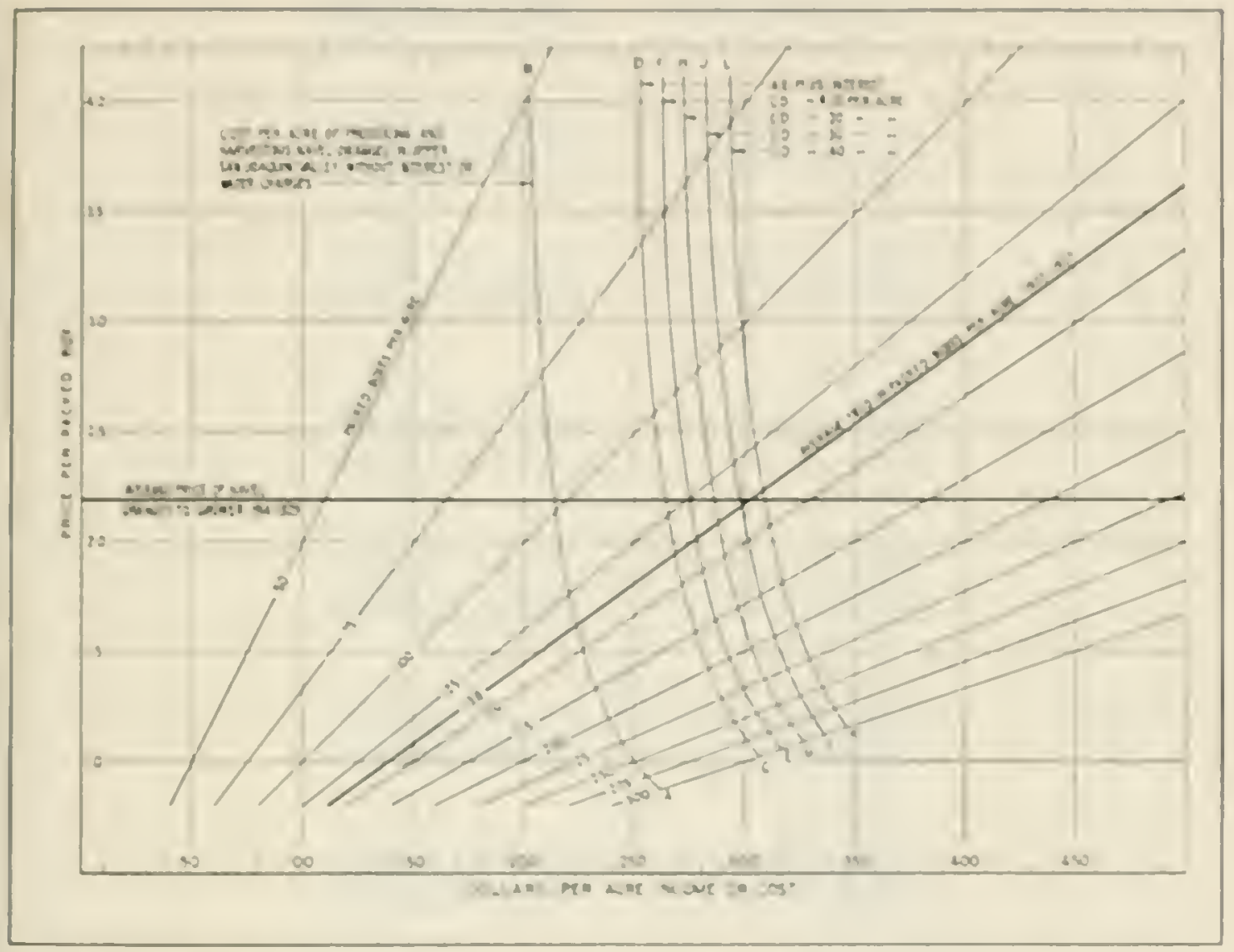

REI.ATIO: BETWFE: COST OF PROUUCING A:D HARVESTING NAVE:I. ORA:ZGES A:UL FARM INCONE.

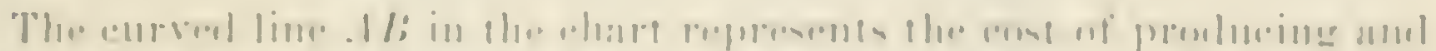

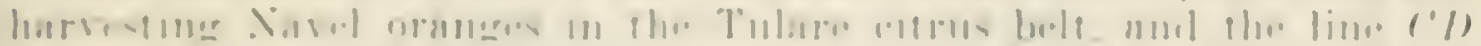

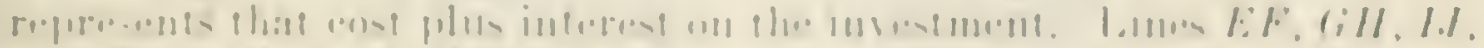

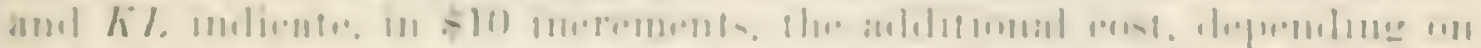

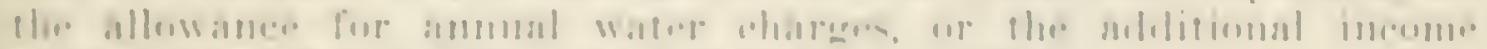

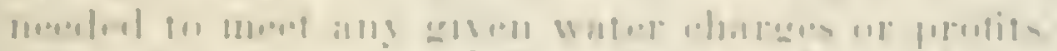

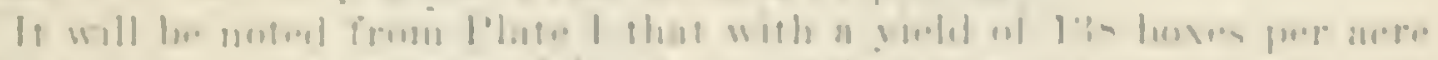

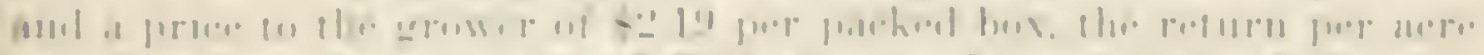

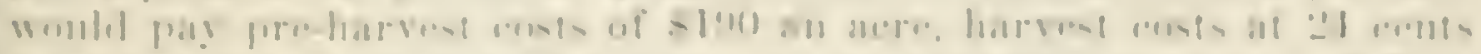

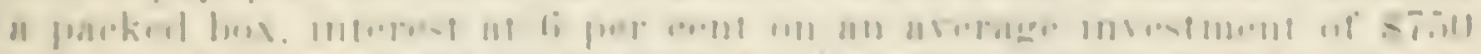

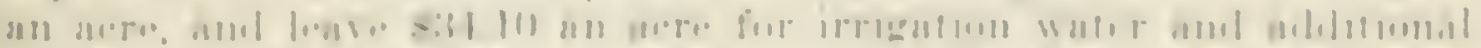

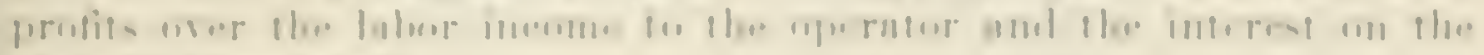

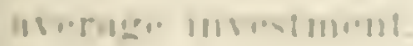

\section{Present Irrigation Cosis in the Fresno. Tulare. Kern Foothill Boll.}

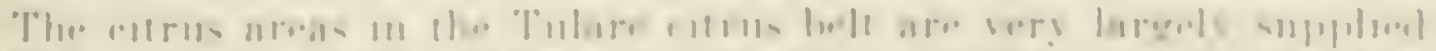

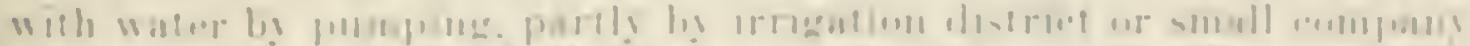

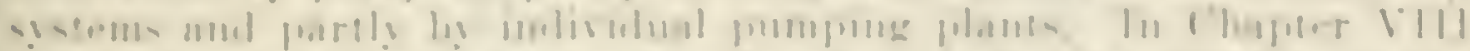

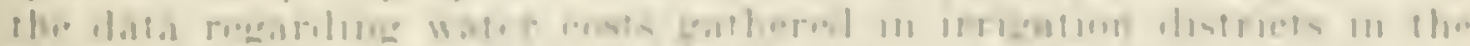

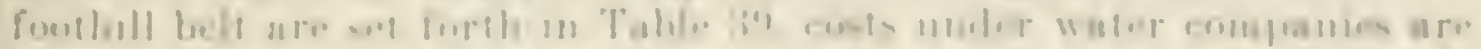

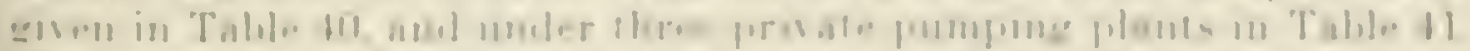

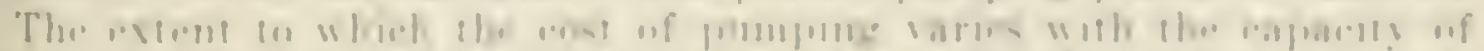

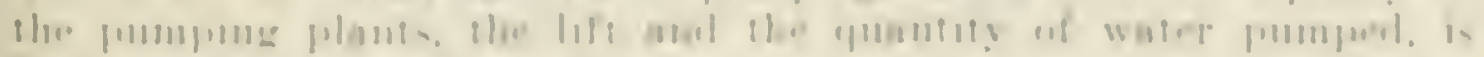
molieglonl in Thlole. 


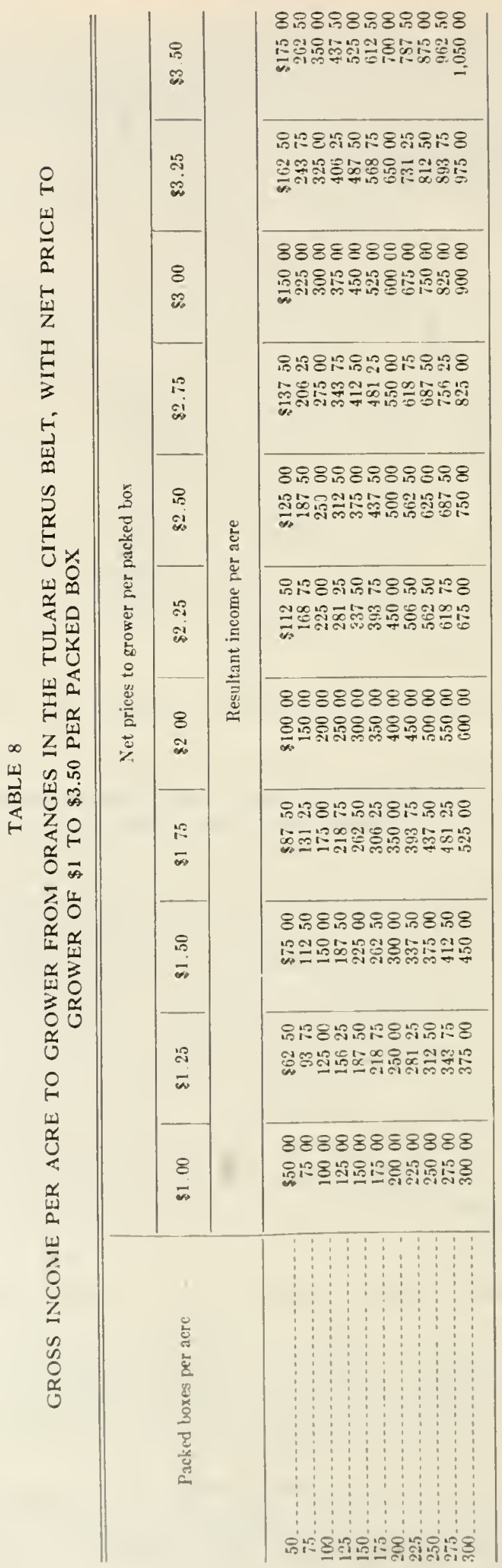




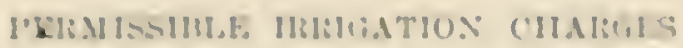

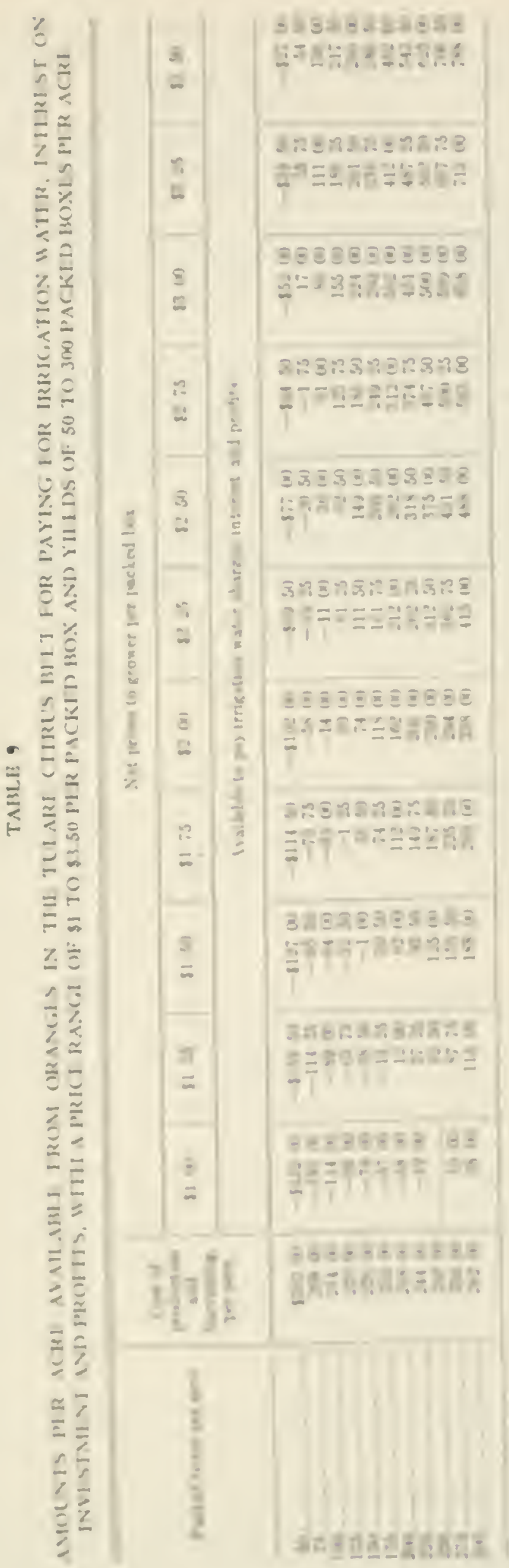


Costs Within Irrigation Districts.-There are three irrigation distriets in the foothill belt, namely: 'Terra Bella, Vandalia, and LindsayStrathmore. 'l'he "usnal" cost to irrigators, as set out in Table 39, ranges from $\$ 25$ to $\$ 66$ per acre per annmm. The averages for the three districts are $\$ 35, \$ 33$ and $\$ 41$, respectively. These averages are eomputed by adding the distriet water tolls to the district assessments, the former figure being computed by multiplying the water toll per aere-foot by the average water dnty in the district. In addition to the averages for the districts, Table 39 gives the eost to thirteen individuals, these ineluding both the distriet eharges and the eost of supplemental pumping.

Costs Under Water Companies.-Table 40 inchdes data for eight companies as a whole and for five individuals minder another eompany. Omitting the figures for one of the companies, which serves more deciduous and other erops. including pasture, than citrus, the costs per acre range from $\$ 27$ to $\$ 62$.

Costs Under Prinate Pumping Plants.-Data for only three farms are given in Table 41. the costs for these being $\$ 31, \$ 34$, and $\$ 30$ per aere, respeetively. 


\section{('H.MP'Tili IV}

\section{Costs of Production.}

\section{DECIDUOUS FRUITS}

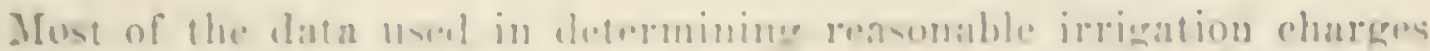

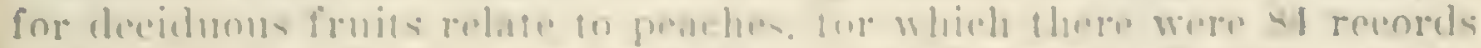

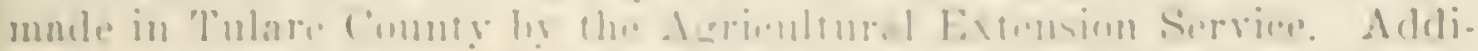

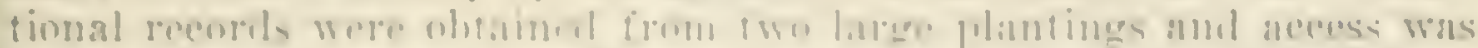

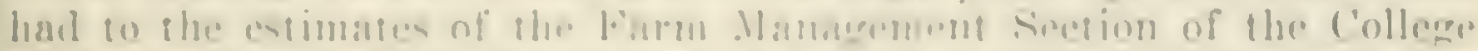

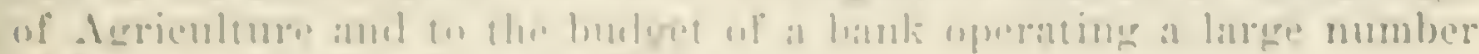
of farms in lhe sian on nomin lislley.

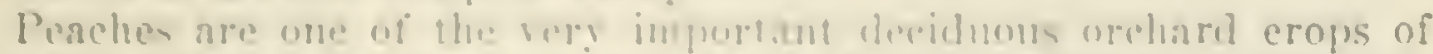

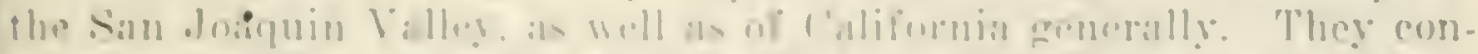

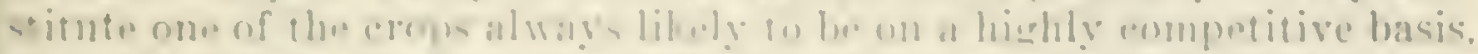

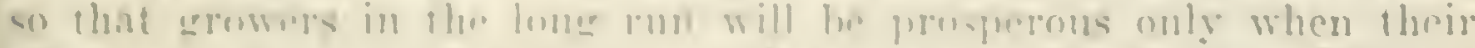

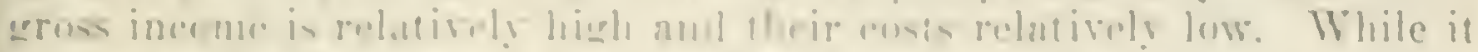

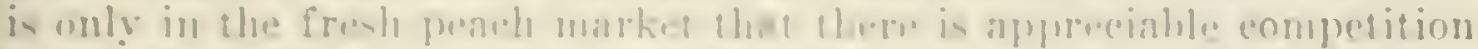

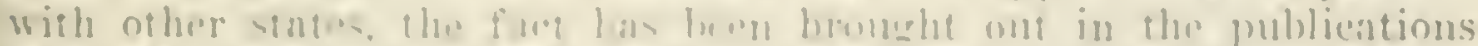

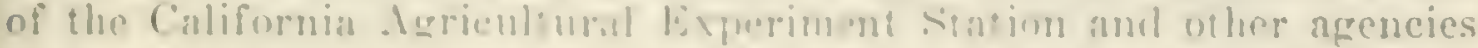

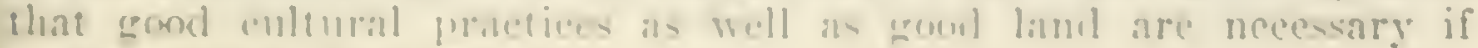

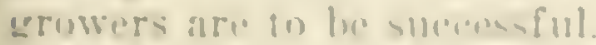

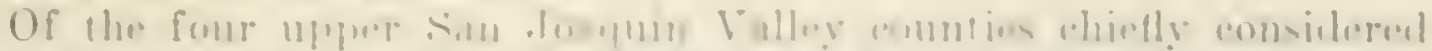

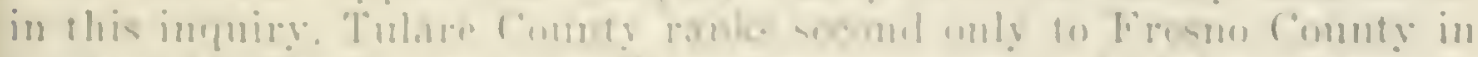

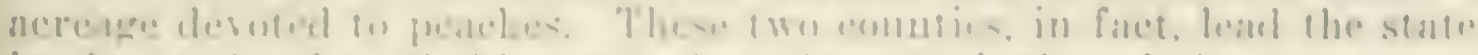

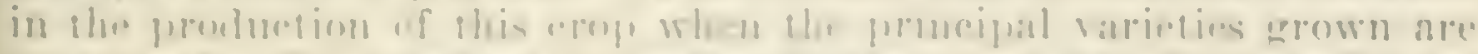

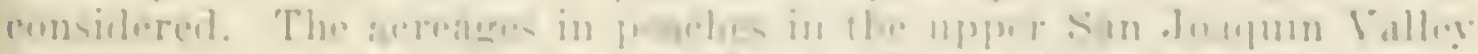

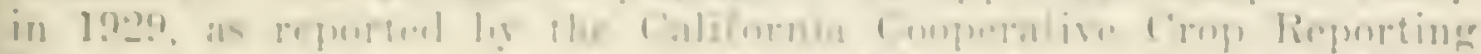

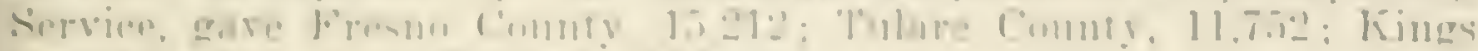

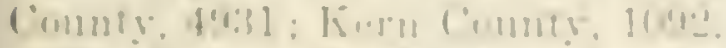

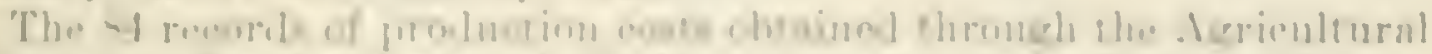

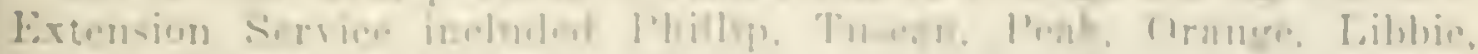

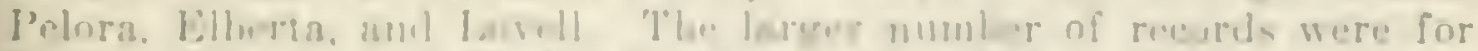

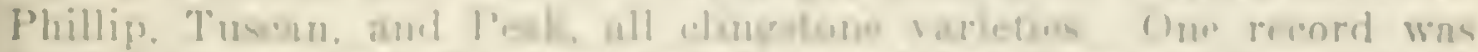

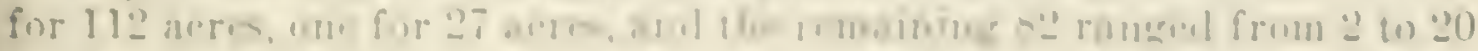
neres.

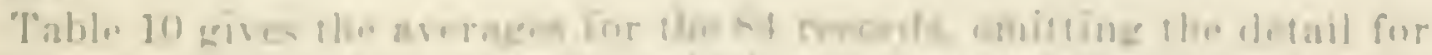

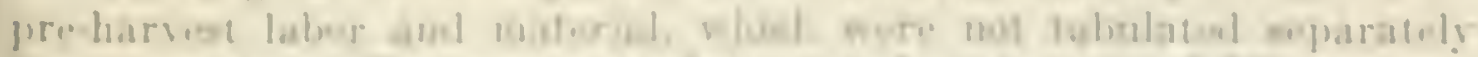

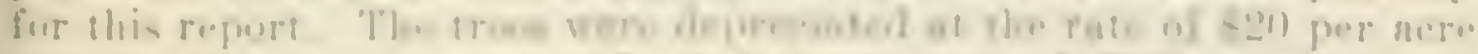

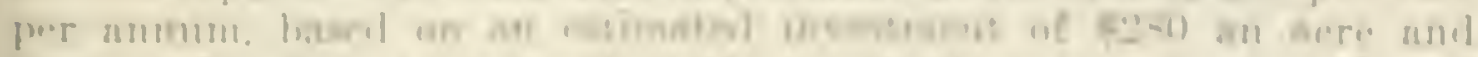

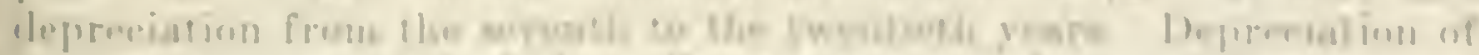

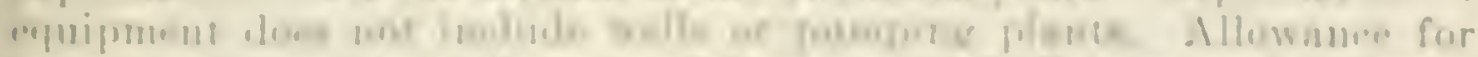

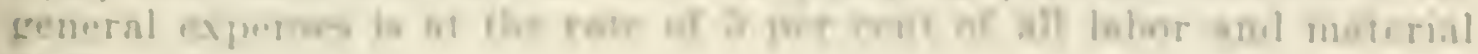
cists

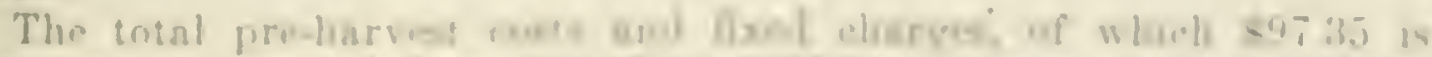

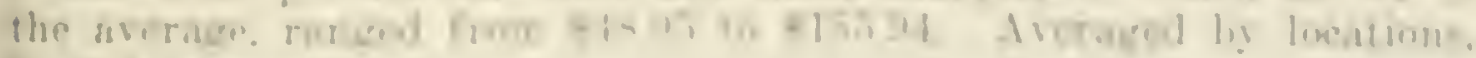
the inisls were:

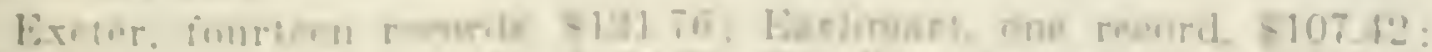

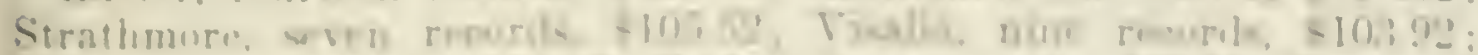

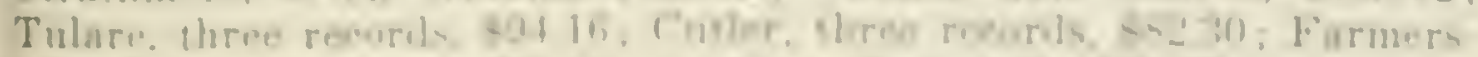

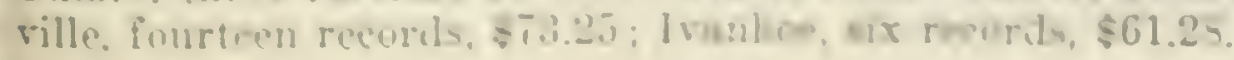


TABLE 10

AVERAGE OF 84 RECORDS OF PRE-HARVEST COST OF PRODUCTION OF PEACHES IN TULARE COUNTY, 1926, 1927, 1928, 1929

Ineludes fixed cxpenses, but not irrigation water or interest.

Ages 6 years or morc.

\begin{tabular}{|c|c|c|c|c|c|c|}
\hline \multirow{2}{*}{$\begin{array}{c}\text { Total } \\
\text { area in acres }\end{array}$} & \multirow{2}{*}{$\begin{array}{l}\text { Pre-harvest } \\
\text { labor } \\
\text { and } \\
\text { matcrials }\end{array}$} & \multicolumn{2}{|c|}{ Depreciation } & \multirow{2}{*}{$\begin{array}{l}\text { Taxes and } \\
\text { insurance }\end{array}$} & \multirow{2}{*}{$\begin{array}{l}\text { Allowance } \\
\text { for } \\
\text { gencral } \\
\text { cxpenses }\end{array}$} & \multirow{2}{*}{$\begin{array}{c}\text { Total } \\
\text { pre-harvest } \\
\text { cost and } \\
\text { fised expenses }\end{array}$} \\
\hline & & Trees & $\begin{array}{l}\text { and } \\
\text { equipment }\end{array}$ & & & \\
\hline 795 & $\$ 6330$ & $\$ 2000$ & $\$ 420$ & 8444 & $\$ 541$ & $\$ 9735$ \\
\hline
\end{tabular}

Some of the recolds for which the location is not certain are not included in this classification.

Table 11 presents the data obtained for the two large holdings of deciduous orchalds previously nientioned. These records are for "trees"; that is, for miscellaneous varictics. As in the ease of the records in Table 10 nothing is included for irrigation water or for interest. Depreciation on improrements and equipment is taken care of in the labor account. Depreciation of trees at $\$ 20$ an acre is added to the recold supplied by the growers.

TABLE 11

COST OF PRODUCTION PER ACRE FOR DECIDUOUS FRUITS ON TWO LARGE SAN JOAQUIN VALLEY TRACTS, 1929, NOT INCLUDING IRRIGATION WATER OR INTEREST

\begin{tabular}{|c|c|c|c|c|}
\hline No. & $\begin{array}{c}\text { Area in } \\
\text { acres }\end{array}$ & $\begin{array}{l}\text { Pre-harvest labor and } \\
\text { material, including de- } \\
\text { preciatiou on improve- } \\
\text { ments and equipment }\end{array}$ & $\begin{array}{l}\text { Depreciation } \\
\text { of trees }\end{array}$ & Total \\
\hline $\begin{array}{l}1 \\
2\end{array}$ & $\begin{array}{l}574 \\
184\end{array}$ & $\begin{array}{r}\$ 5557 \\
6190\end{array}$ & $\begin{array}{r}\$ 2000 \\
2000\end{array}$ & $\begin{array}{rl}\$ 75 & 57 \\
8190\end{array}$ \\
\hline
\end{tabular}

Six rarieties of deciduous fruits are ineluded in the budget data furnished by the bank previonsly referred to. Table 12 gives the itemized estimates for each erop, these being intended to amply eover

TABLE: 12

BUDGET ESTIMATES OF A SAN JOAQUIN VALLEY BANK COVERING COST OF PRODUCING CERTAIN DECIDUOUS FRUITS I

\begin{tabular}{|c|c|c|c|c|c|c|c|c|c|}
\hline Variety & $\begin{array}{l}\text { Plowing } \\
\text { and } \\
\text { cultivat- } \\
\text { ing }\end{array}$ & l'ropping & $\begin{array}{l}\text { Pruning, } \\
\text { brush } \\
\text { disposal }\end{array}$ & Thinning & Spraying & $\begin{array}{l}\text { Irrigation } \\
\text { labor }\end{array}$ & $\begin{array}{c}\text { Deprecia- } \\
\text { tion } \\
\text { on } \\
\text { trees }\end{array}$ & $\begin{array}{c}\text { Total } \\
\text { without } \\
\text { dejuecia- } \\
\text { tion, } \\
\text { general } \\
\text { expenses } \\
\text { and taxes }\end{array}$ & $\begin{array}{l}\text { Total with } \\
\text { allowance } \\
\text { for } \\
\text { deprecia- } \\
\text { tion, } \\
\text { general } \\
\text { expenses } \\
\text { and taxes }\end{array}$ \\
\hline 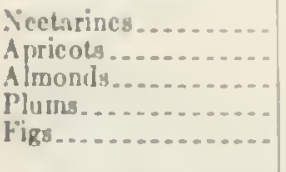 & $\begin{array}{l}\$ 1100 \\
1100 \\
1100 \\
1100 \\
1100\end{array}$ & $\begin{array}{r}\$ 500 \\
200 \\
\hdashline- \\
\hdashline\end{array}$ & $\begin{array}{r}11200 \\
1200 \\
500 \\
1000 \\
800\end{array}$ & 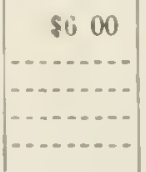 & $\begin{array}{r}\$ 10 \\
800 \\
1000 \\
1000 \\
400\end{array}$ & $\begin{array}{ll}\$ 5 & 00 \\
5 & 00 \\
5 & 00 \\
5 & 00 \\
5 & 00\end{array}$ & $\begin{array}{l}\$ 2000 \\
2000 \\
2000 \\
2000 \\
2000\end{array}$ & $\begin{array}{rl}\$ 49 & 00 \\
38 & 00 \\
31 & 00 \\
26 & 00 \\
28 & 00\end{array}$ & $\begin{array}{ll}\$ 52 & 00 \\
71 & 00 \\
6100 \\
5900 \\
0100 \\
.\end{array}$ \\
\hline
\end{tabular}

IIrigation water and Interest are not included. 
actual oporation. willonut either depreviution or interest. The same ifem ins depreriation of trees und in lhe preceding table has ben addind

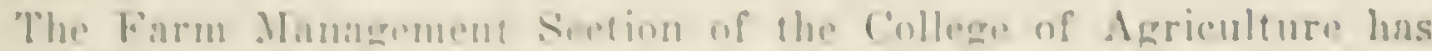

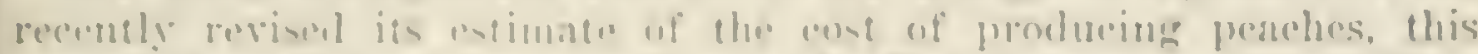

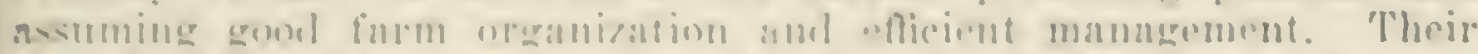

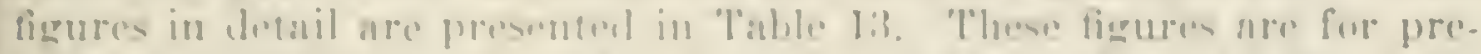

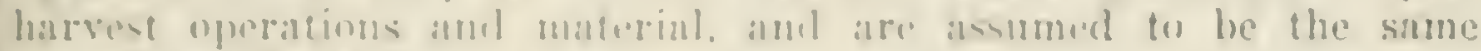

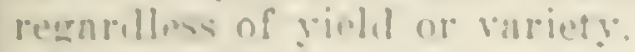

T.M136:1: 13

COST PIR ACRE: OI: PRODUCIVG MIACIIS. AS ISTIMATID IBY TIIE IPARM .MANAGIMIIN SICTION, COILIGE OI: ACIRICUITUIRL, IVCLUISIS, INTI:IRIST AND DIPRI CIATIOX UN IMIII WI NTS AVI) WOKK STOCK

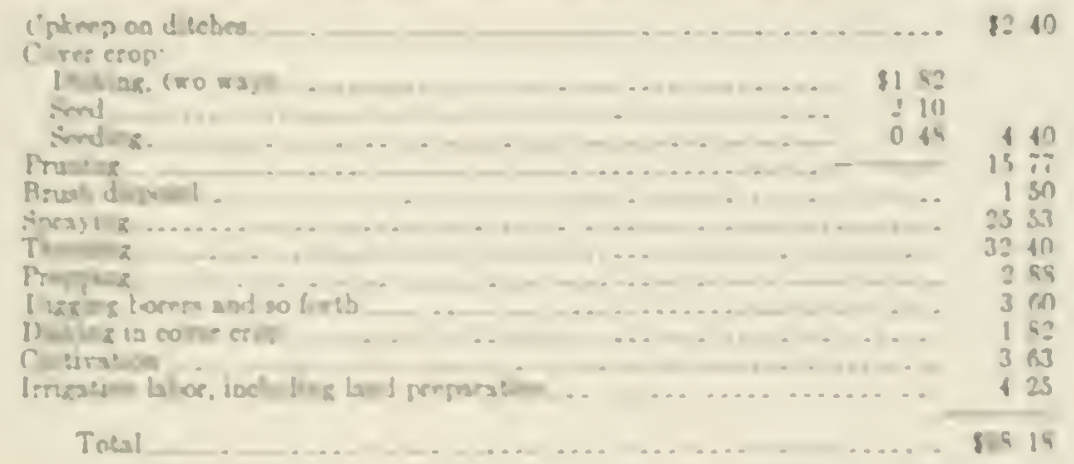

In tablo 13 there is implubled an alluwance for interest and deprecia-

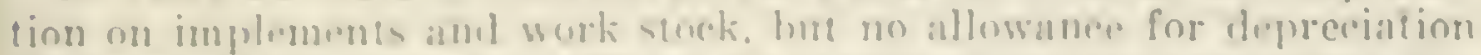

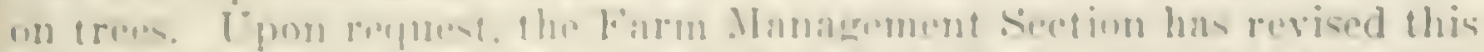

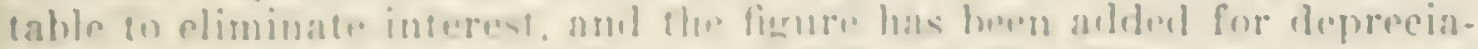
tion on trees, as is eriven in 'lahles 10. 11. and 1:. These revisions are given in liale 14.

TMIII 11

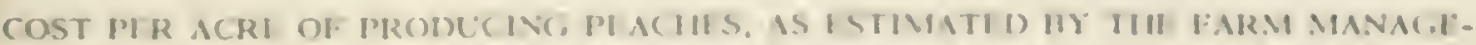

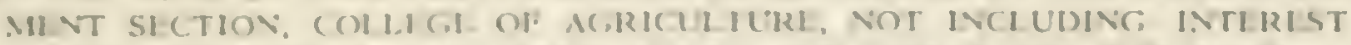

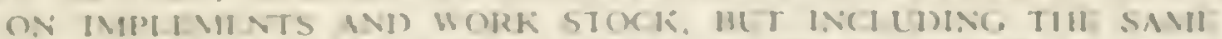

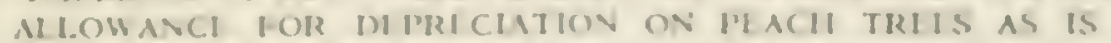
USID IISI WIIIRI IN THIIS IHIDORT

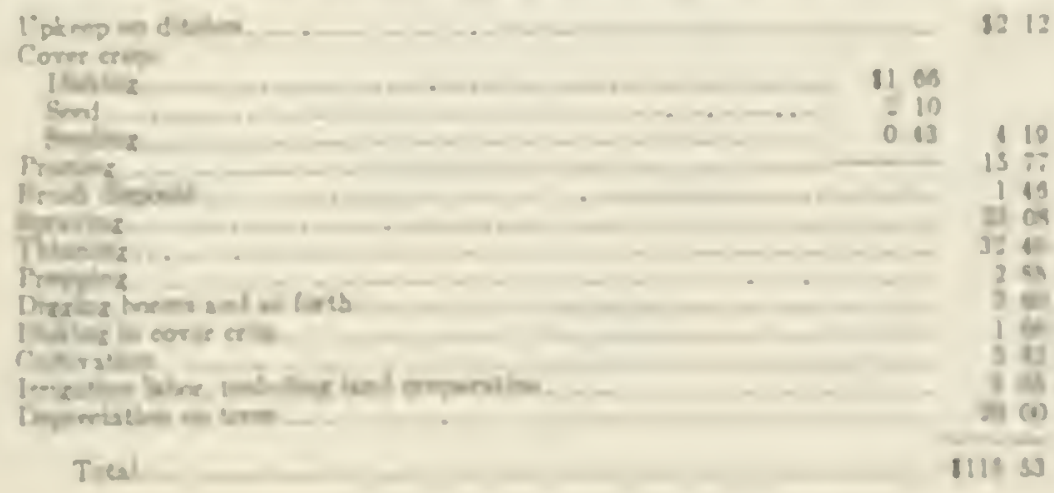

It will be noted thot ihe imals prow uted in "Tobles 11 and 12 are

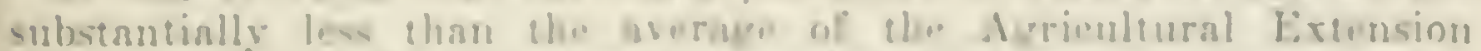

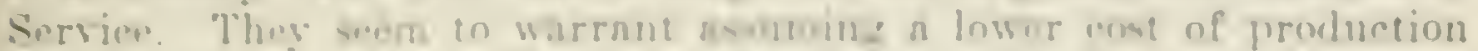

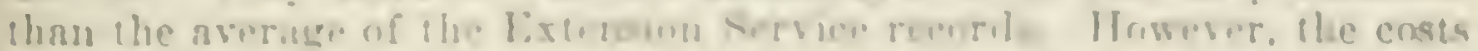

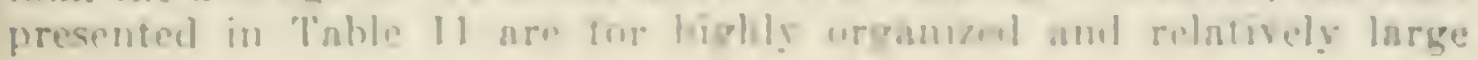


cnterprises. and the effieiency of operation reflected in the costs ean not be duplieated on the nemal individual holdings. The bank budget figures presented in Table 12 likerwise must he given less weight for the purposes of this inquiry than those of the Extension Service, because the holvlings for which they have been made are in proeess of finaneial readjustment, during whieh time some items are usually neglected, and beeause the centralized administration of the property should result in sarings which inclividual farmers ean not aceomplish. The figures given in Table 13 and revised in Table 14 are substantially higher than those shown by the $8 t$ Agrieultural Txtension Service records, but it sliould be remembered that the Farm MIanagement Seetion figures are intended to renresent certain definite conditions which ean not be expected to be reflecter in averages of a large number of individual reeords.

After considering the general enditions and hazards in the deciduous fruit industry and the ennseruent need for enuservatism, it is believed the averages shown in Tables 11 and 12 should not be used as a basis for enelusions. but that the average shown by the 84 Agrieultural Fxtension Service reenrts shonld even be increased. The basis for this inerease is the higher ensts presented by the Farm Management Seetion and the need for adding to the amount allowed for spraying. The average amount spent for spraving in the Tulare area is between $\$ 5$ and $\$ 6$ an aere. It is the recommendation of specialists that this figure should not be less than $\$ 1$. For purposes of this report the average of the Tulare County reeords has been raised to the round figure of $\$ 105$ an aere for total pre-harvest costs and fixed elariges.

Starting in, then, with a total pre-harvest cost, together with fixed charges, amonnting to $\$ 105$ an acre, Table 15 has been prepared to show the eost with harvesting ineluded. The table covers a range of yield of from five to twetre tons per acre. IIarvesting costs are added at rates varying from $\$ 5.50$ a $t \mathrm{nn}$ for rields of five tons to $\$ 4.50$ a ton for rields of twelve tons.

TABLE 15

AVERAGE COST PER ACRE OF PIRODUCING AND ILARVESTING PEACHES IN TULARE COUNTY

Cest of production taken at $\$ 105$ an acre: horvesting figured at from $\$ 5.50$ a ton for yields of five tons lo $\$ 1.50$ a ton for yielis of twelve tons per acre.

\begin{tabular}{|c|c|c|c|}
\hline $\begin{array}{l}\text { Yield in tons } \\
\text { pre acre }\end{array}$ & $\begin{array}{c}\text { Average eost } \\
\text { per aere }\end{array}$ & $\begin{array}{l}\text { Yield in tons } \\
\text { per acre }\end{array}$ & $\begin{array}{l}\text { Average cost } \\
\text { per acre }\end{array}$ \\
\hline $\begin{array}{l}5 \\
5 \\
7 \\
8 \ldots\end{array}$ & 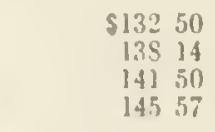 & $\begin{array}{c}9 \\
10 \\
11 \\
12 \ldots \ldots \ldots\end{array}$ & $\begin{array}{l}\$ 14957 \\
15286 \\
15607 \\
15900\end{array}$ \\
\hline
\end{tabular}

Income from Peaches and Amount Available for Irrigation Water Chargos.

Talble 16 shows the income per nere with a yield of five to twelve tons

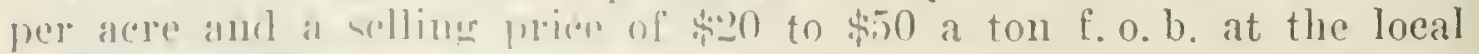
delivery point. 
ТАแ 16

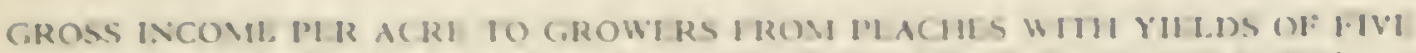

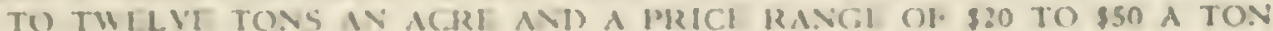

\begin{tabular}{|c|c|c|c|c|c|c|c|}
\hline Ir bet $1=$ & 8. & 8.3 & $s$ & s3s & 810 & 813 & $8: 0$ \\
\hline s...tnk . w & $81(0)$ & $\$ 1.3$ & 8130 & $81: 3$ & 1201) & 5223 & 8230 \\
\hline 6 & 1. & 130 & 100 & 210 & $: 10$ & 200 & $30 n$ \\
\hline i. $\quad \ldots$. & 160 & 173 & 210 & :15 & $=40$ & 313 & 350 \\
\hline$\pm \ldots \ldots \ldots$ & $1 \omega$ & 2ir) & $\Delta 1$ & $=\$ 0$ & $3: 0$ & 360 & $4(0)$ \\
\hline $9 \ldots \ldots$ & $1 \times 0$ & $\therefore 3$ & ?io & 313 & 360 & 123 & 150 \\
\hline $10 \ldots \ldots$ & $\cdot(x)$ & .30 & (xis) & 3S) & 100 & 450 & $3(0)$ \\
\hline $11 .+\ldots$ & 200 & 273 & 10 & 34 & 110 & 123 & 330 \\
\hline $12 \ldots-\ldots-1-$ & $=10$ & 3 i) & 3 & 1.0 & 150 & 310 & (a) \\
\hline
\end{tabular}

Plate II has heren prepared ter lacilitate determination of the vields

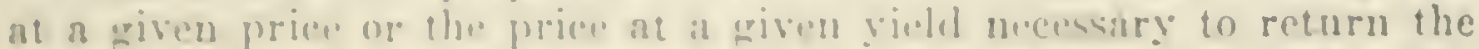

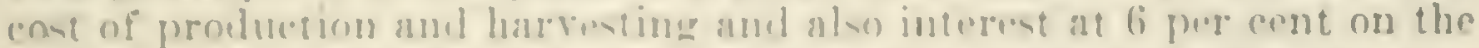
nverage inventuent. "The rupve oll' in this plate indientes the cost

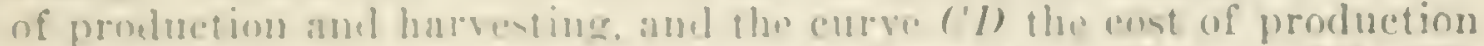

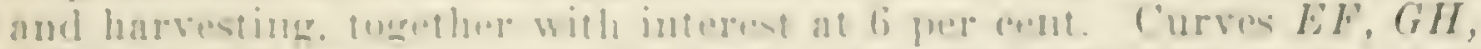

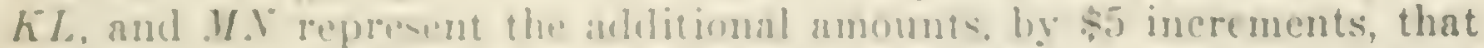
miglit. uncler elifierent asumptions, be repuired to cover the cost of irrigation water.

PLATE: II

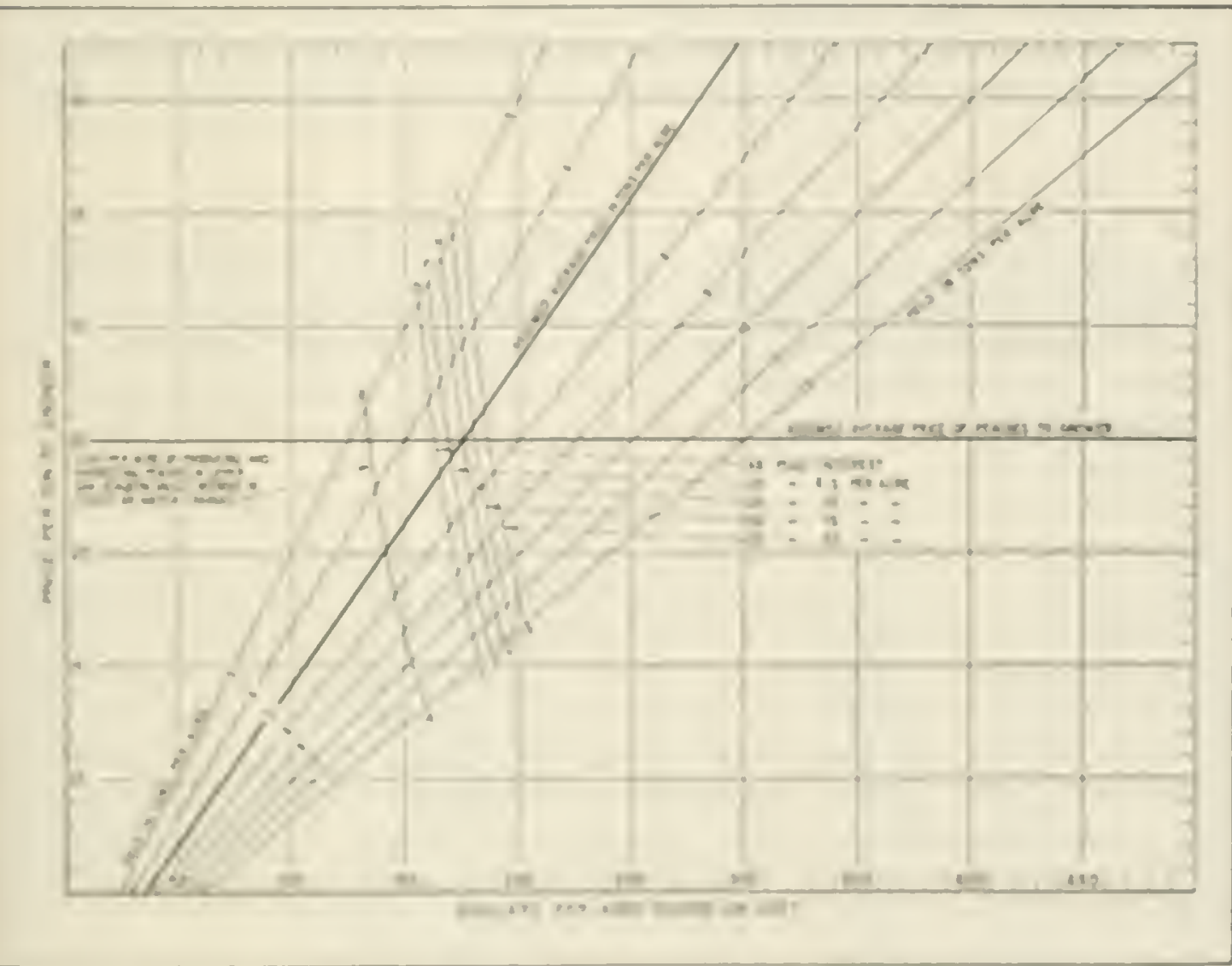

RELATIO:: BETWEE: COST OP PRODUCI:G A:U HAKVESTI:G PEACIIES A:ID PARM I:CONR

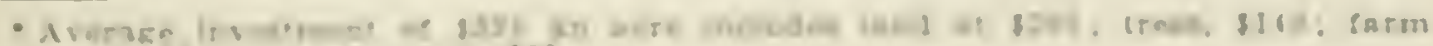

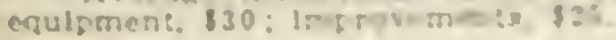


It now becomes necessary to determine the amount of the farm income, above cost of production and harvesting, out of which costs for irrigation water are to be taken. 'T'o do this it is necessary to assume a vield and a price for peaches which ean be taken as a safe estimate for the future.

The average rield of peaches during the past four years for the s4 reeords obtained through the Agrieultural Extension Service for Tulare Comnty was 7.72 tons an acre. According to Agrieultural Extension Service Circular 1, the average * price received by the @rowers for elingstones dming the period 1901-1925 was \$39 a ton, and for freestones during the same perior. \$30 a ton. The same publication gives the average for the period 1921-1925 as the same. In the case of elingstones the range was from $\$ 12$ to $\$ 100$, with the price below the average in 15 years ont of the 25. Tn the case of freestones, the range was from $\$ 10$ to $\$ 64$, with the price again below the average in 15 out of 25 years.

On the assumption that growers may, on the average, obtain a yield of 7 tons an acre and that on the avelage they will receive a price of was a ton. Plate IT indieates that the return an aere to the growers would be $\$ 210$. This is $\$ 68.50$ an acre in excess of the cost of producing seven tons an acre. If this rield and this price were to be obtained as an average orer a periort of years. g'rowers could pay as high as $\$ 20$ an acre for irrigation water and still show a profit of $\$ 2+.80$ an acre over all costs, including depreciation, interest, and water. With a price of $\$ 25$ a ton.t which secms a maximum figure to assume, the malgin above enst of prodnetion and harvesting. together with interest on the average investment. would be redneerl to $\$ 9.80$ an acre. The situation is presented maphically in Plate IT.

In ardition to the cost data relating to peaches obtained from the Falm Mamagement Section of the College of Agrienlture. and already given in Tables 13 and 14. similar information has been obtained from that section relating to apricots. Their total pre-harrest eost per acle. inchuling interest and depleciation on equipment and work stock, an irrigation water charge of \$5.62, comnty taxes, and depreeiation on trees, is $\$ 166.25$ for a six-ton rield of caming fruit, and $\$ 149.35$ for a foum-ton vicld.

Becanse interest on the entire investment. as well as the cost of irrigation water, is included in the enst data reported in Agricultural Extension Cirenlar 24, the data available from that somec for deciduous linits a ne net entipely comparable with figures supplied by the

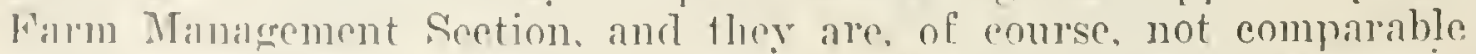
with the eosts for pearhes as presented in the diseussion of that erop. Howrever, the fiomeres show lelative ensts and they therefore are included

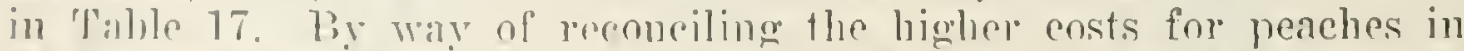
sulter and stanislans romuties it might be stated that the yields in the latfore comblies for the renolels grivell ale appreciably higher than

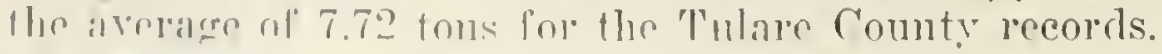

- linwelehler average.

† Thle flgur" has henn abluturily choson as the highest it secms reasonable to

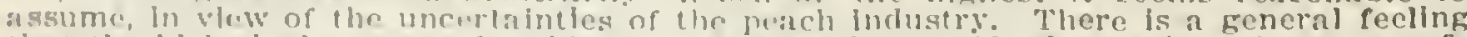

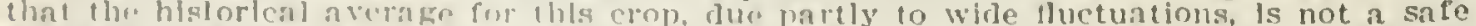

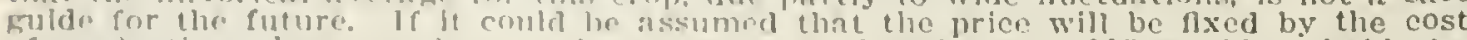
if limfluctim whrer pracling cin le grown most cheaply, even $\$ 25$ would probably be too high. 
INBI I:

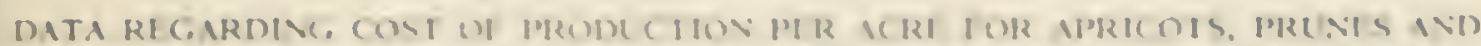

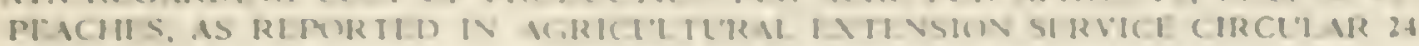

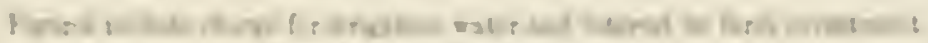

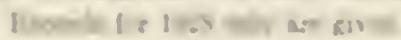

\begin{tabular}{|c|c|c|c|c|}
\hline Ire: & Cesris & $\because=i$ & $\operatorname{lip}_{1+x \rightarrow b}$ & 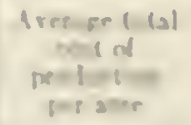 \\
\hline 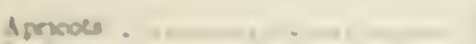 & $y=6$ & 4 & .2 & $11=i$ \\
\hline inreser & tivents is & ; & $5 \div$ & $1 \times 1 \times 1$ \\
\hline Apribure $\quad .-1-\ldots$ & reodink $-1-1-1$ & It & 7 & $1: 0.1$ \\
\hline Pre $\ldots \ldots-\ldots$ & 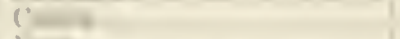 & 1 & $\because$ & $1: 37$ \\
\hline Frese :.. & 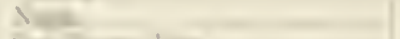 & .1 & 341 & $147:$ \\
\hline 1tuven. $\quad . .$. & $2+2+2=$ & is & 4 & $111=1$ \\
\hline Preace a.. & siment & i: & .11 & $1+9=3$ \\
\hline Brasen - .... & solit & .1 & ilis & $1+4$ \\
\hline Pescher.............. . & 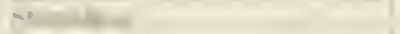 & Th & -11 & 21350 \\
\hline Reubes. & $=19 \cdot$ & 94 & $\therefore$ & $2: 111$ \\
\hline Pes-bee ... . & Tilonest & 3 & at & 1607 \\
\hline Pracber : & Y $x=$ & $\therefore$ & -1 & jor 14 \\
\hline
\end{tabular}

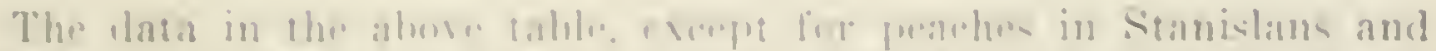

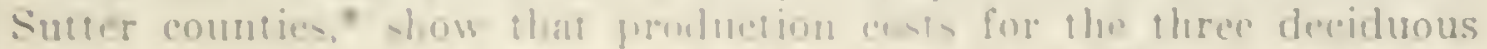

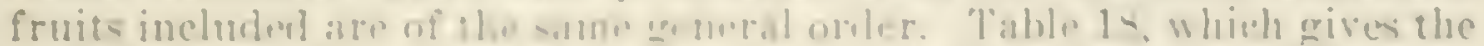

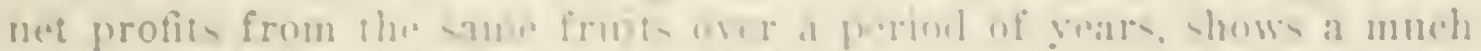

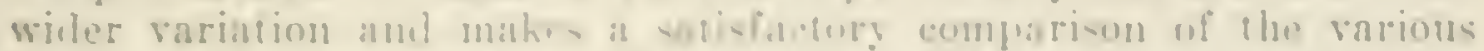

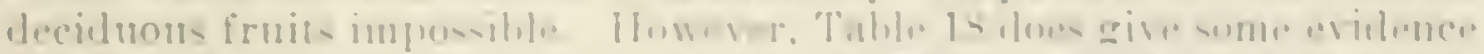

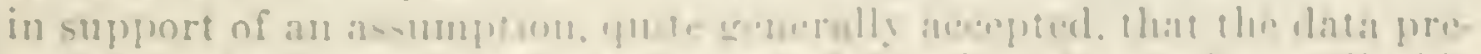

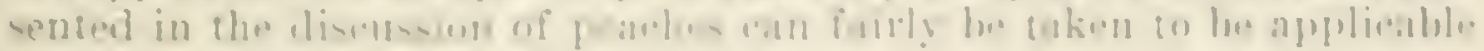
to opler deciluens frolis.

I 1 III I I

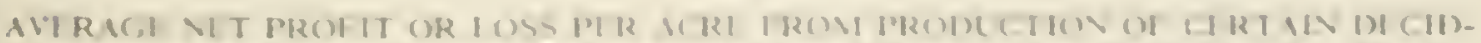

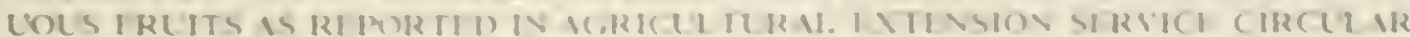

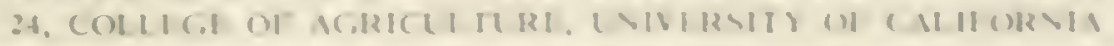

\begin{tabular}{|c|c|c|c|c|c|}
\hline$y=8$ & I sur & resali & $d_{p}=$ & $1=$ & 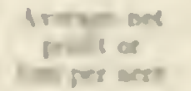 \\
\hline inribat. & 10 & $16 \operatorname{los}$ & y & 116 & $115=$ \\
\hline Arredt $-1-\ldots$ & 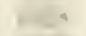 & $14=-3$ & 1 & $\underline{2}$ & - in $t$ \\
\hline 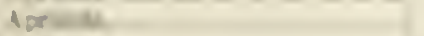 & $1=$ & brasta & 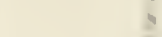 & 4 & 6 H \\
\hline Antous , , , , & $10 \%$ & $10=$ & 2 & $i$ & (1) 16 \\
\hline 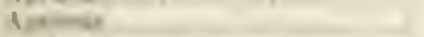 & 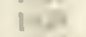 & 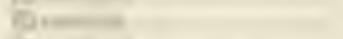 & , & का & $\mathrm{ra}$ is \\
\hline $1 p=4 k \ldots$ & $i=y^{2}$ & 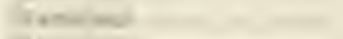 & 11 & $\mathrm{~g}^{4}$ & 114 \\
\hline ipenta... & in: & $4=$ & 11 & ? & 10 \\
\hline Proter. & 17 & 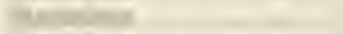 & It & $w^{n}$ & 1611 \\
\hline Des: & 70 & $2+4=0-20=$ & 27 & -1 & $2 \pi \cdot n$ \\
\hline Prestes & ving & $4 a x=0$ & 4 & 111 & -3. \\
\hline Puerles $\ldots \ldots$ & $1 w=$ & 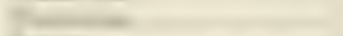 & ta & 1 & It is \\
\hline Prackis - $\ldots$ & $\sqrt{1} x^{4}$ & $1200=5-20$ & $y$ & 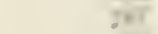 & (1) 13 \\
\hline Racken is & $1=$ & $1+x+2=0$ & 3 & $\sqrt{n}$ & 12 6 \\
\hline Pouk & $1+2$ & $\mathrm{~T}+\mathrm{w}^{-}$ & (1) & 11 & lit \\
\hline fimes & Jint & 1.25 & it & 114 & $-y^{*}=4$ \\
\hline Nack . - & 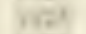 & $7+x+1$ & 24 & $\mathrm{Ey}$ & $=24$ \\
\hline Prate & +4 & $18=0$ & 14 & 16 & 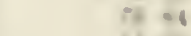 \\
\hline$r$ & 28 & 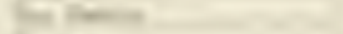 & 11 & 1 & $1 A=$ \\
\hline Prges & 126 & $\ln 20$ & If & 111 & $11 \%$ \\
\hline Preses. & -3 & 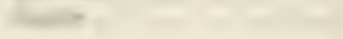 & 1 & $r$ & 761 \\
\hline
\end{tabular}

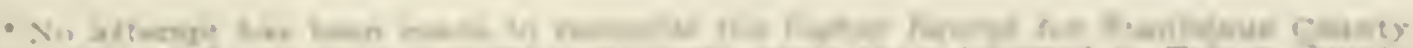

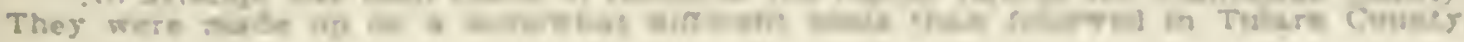


Costs of Irrigation Water in the Upper San Joaquin Deciduous Fruit Areas.

Deciduous fruits are not localized as are citrus fruits, but are scattered thronghout the developed portions of the areas south of Kings River, exeept in the 'Tulare Lake bottom grain sections. However, they are most lingely found under the main sonthside Kings River irrigation systems-Alta Irrigation District, Peoples Ditel Company, and Lucerne and Lemoore Irrigation Districts - and in the vicinity of Tulare Trrigation District, in the Delano-MIcFarland section, and in the Kern River areas southeast of Bakersfield. Present irrigation costs in these sections are given in Tables 42, 44, 48, 53, 55, and 56 .

Costs per acre under the Ker'n River ditches ('Table 42) are low, ranging from 63 to 99 cents, to cite figures for East Side and Kern River eanals only, not inchuding additional costs of operating private pumping plants. Under the Fings County water companies (Table 48) the approximate average ensts range from 93 cents to $\$ 2.45$. Under the Kaweah River Delta canals cited (Table 5.3) the range is $\$ 1.01$ to $\$ 3.28$, with some supplemental private pumping not included. For areas supplied exchusively by private pumping plants ('Tables 44 and 55) the range in the six eases eited, which are those that inchde deciduous fruits as among the erops irrigated, is $\$ 10.40$ to $\$ 17.60$ per acre. 


\section{('H.IP'THI I"}

\section{Costs of Production.}

\section{GRAPES}

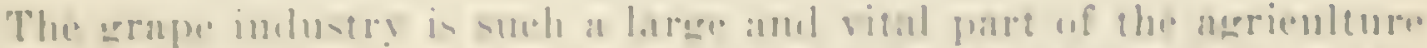

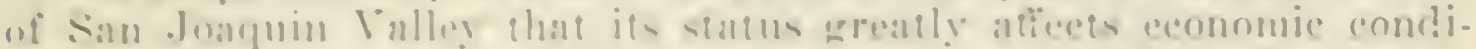

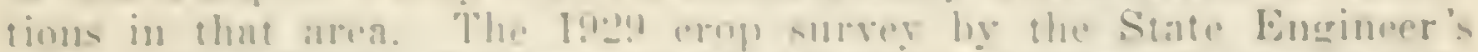

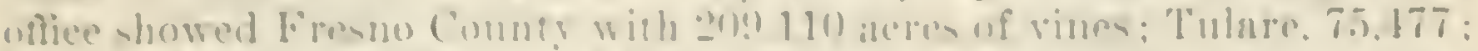

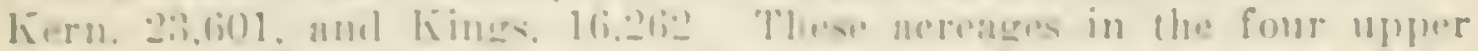

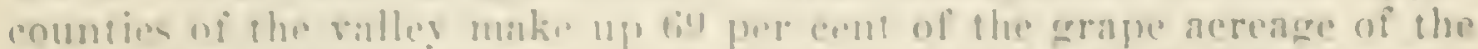

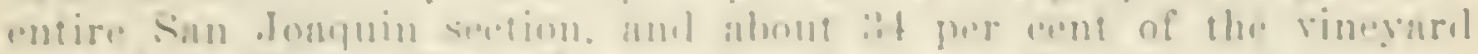
nrea of the liniml staths."

From a แลе -

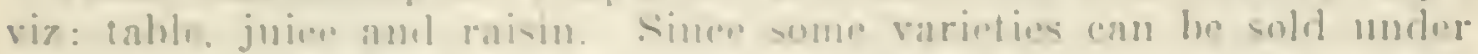

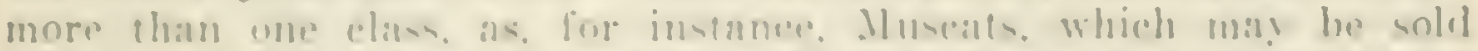

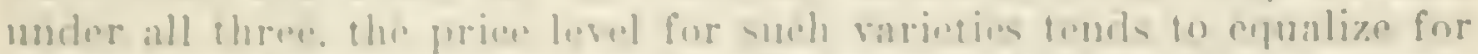

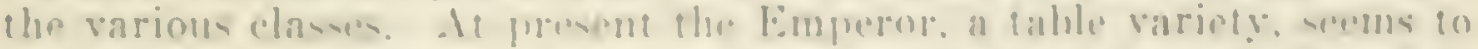

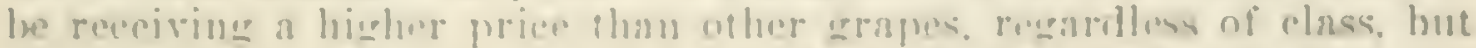

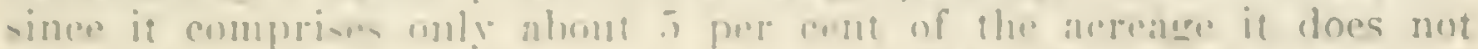

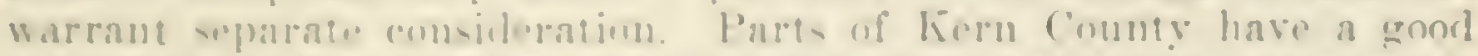

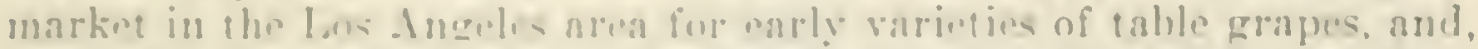

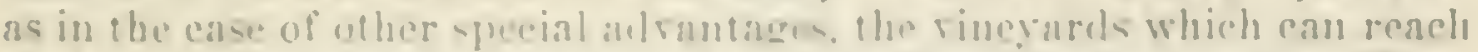

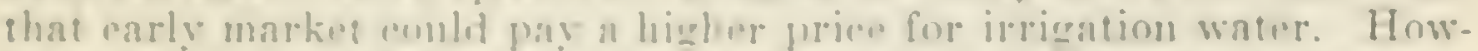

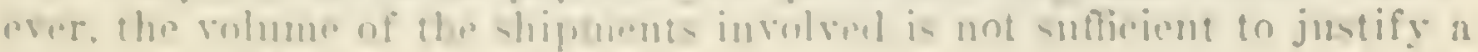
-precial classifuntion in this repmet

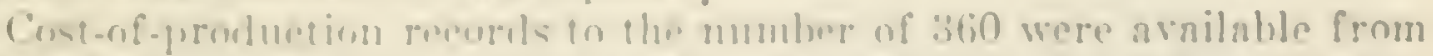

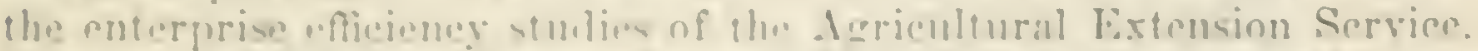

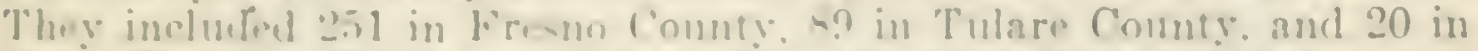

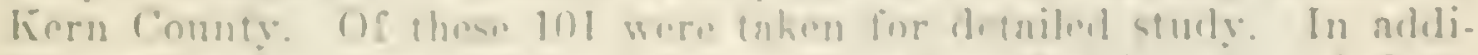

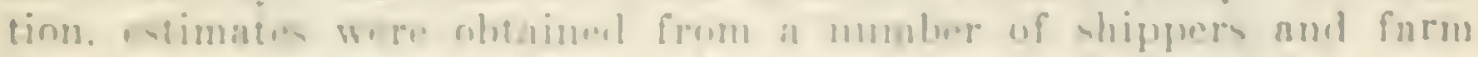
managers and eont recorls were tornishol directly by several farmers whe krepp rest aecerlums.

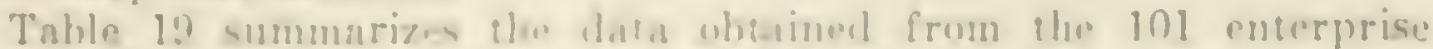

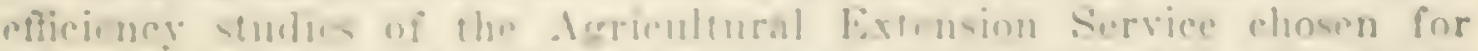

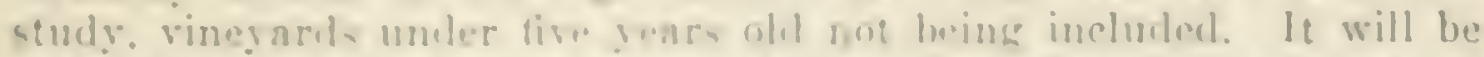

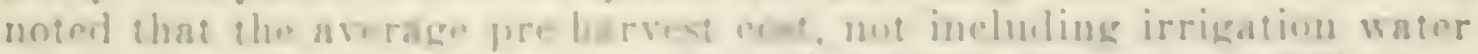

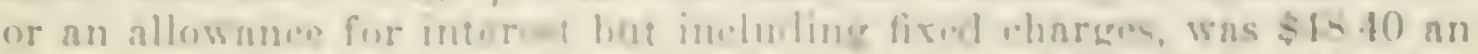

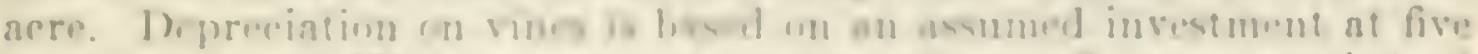

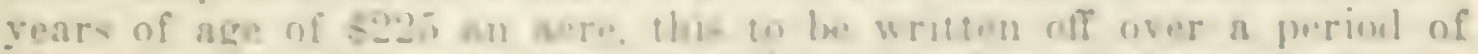

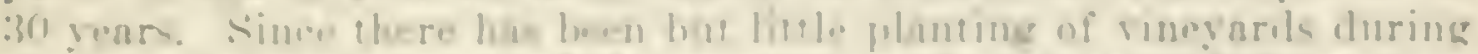

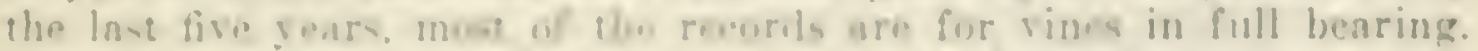

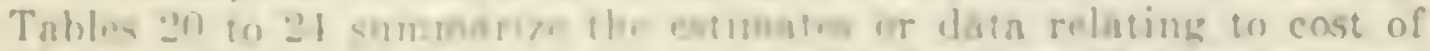

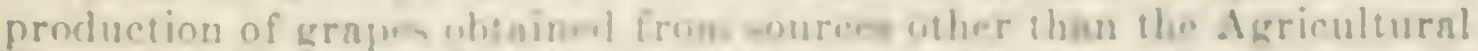

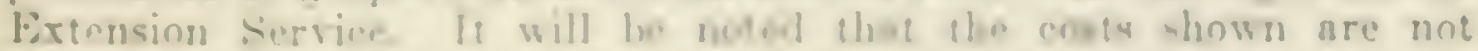

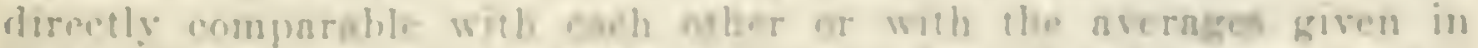

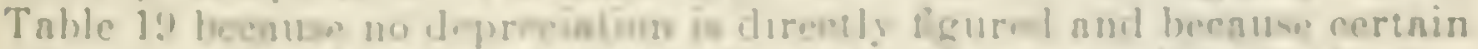

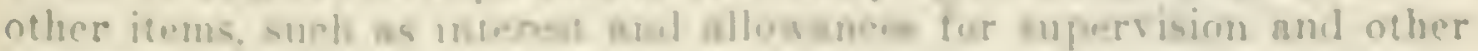

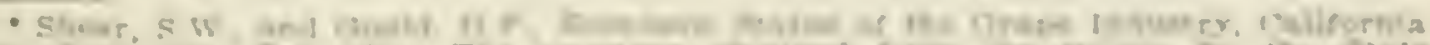

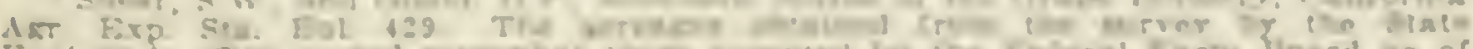

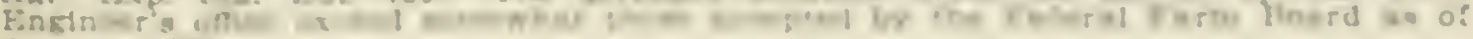

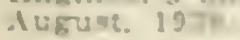


TABLE 19

SUMMARY OF DATA RELATING TO THE PRE-HARVEST COST PER ACRE OF PRODUCING GRAPES, INCLUDING FIXED CIIARGES, BUT WITH NO ALLOWANCE FOR IRRIGATION WATER OR INTEREST

Data obtained from 101 enterprise efficiency studies made by the agricultural extension service in Fresno, Tulare and Kern counties, 1926 to 1929

\begin{tabular}{|c|c|c|c|c|c|c|c|c|}
\hline \multirow{2}{*}{$\begin{array}{l}\text { Total acreage, } \\
\text { approximately }\end{array}$} & \multirow{2}{*}{$\begin{array}{c}\text { Pre- } \\
\text { harvest } \\
\text { cost for } \\
\text { labor and } \\
\text { materials }\end{array}$} & \multicolumn{3}{|c|}{ Annual depreciation } & \multirow{2}{*}{$\begin{array}{c}\text { Texes } \\
\text { and } \\
\text { insurance }\end{array}$} & \multirow{2}{*}{$\begin{array}{l}\text { Incidental } \\
\text { expenses }\end{array}$} & \multirow{2}{*}{$\begin{array}{l}\text { General } \\
\text { expense }\end{array}$} & \multirow{2}{*}{ Total } \\
\hline & & Vines & $\begin{array}{l}\text { Improve- } \\
\text { ments }\end{array}$ & $\begin{array}{l}\text { Equip- } \\
\text { ment }\end{array}$ & & & & \\
\hline 800. & $\$ 2926$ & $\$ 750$ & $\$ 092$ & $\$ 165$ & $\$ 495$ & $\$ 012$ & $\$ 300$ & $\$ 48 \quad 40$ \\
\hline
\end{tabular}

overhead, are not treated on a uniform basis. In one case especially (Table 2t) the conditions under which the crop were grown were unrepresentative. In spite of the difference involved, the material is included because it shows something of the variation in the data which must be expected in such a study as that reported herein. The summary of the data in Tables 20 to 24 , given in Table 25 , facilitates comparison.

TABLE 20

COST PER ACRE OF PRODUCING 20 ACRES OF EMPEROR GRAPES, AS ESTIMATED BY A SUCCESSFUL GROWER AND SHIPPER NEAR PORTERVILLE

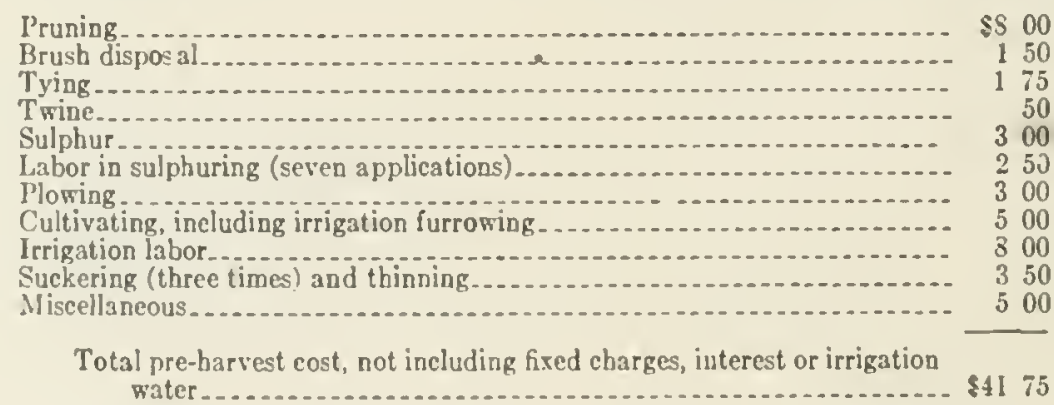

TABLE 21

LABOR AND MATERIAL COSTS PER ACRE ON LARGE ACREAGE OF VINEYARD AT DELANO, 1929, NOT INCLUDING IRRIGATION WATER AND WITH NO ALLOWANCE FOR INTEREST OR FIXEDD CHARGES

Varieties included Thompson, White Malagas, Empcror, Museat and others.

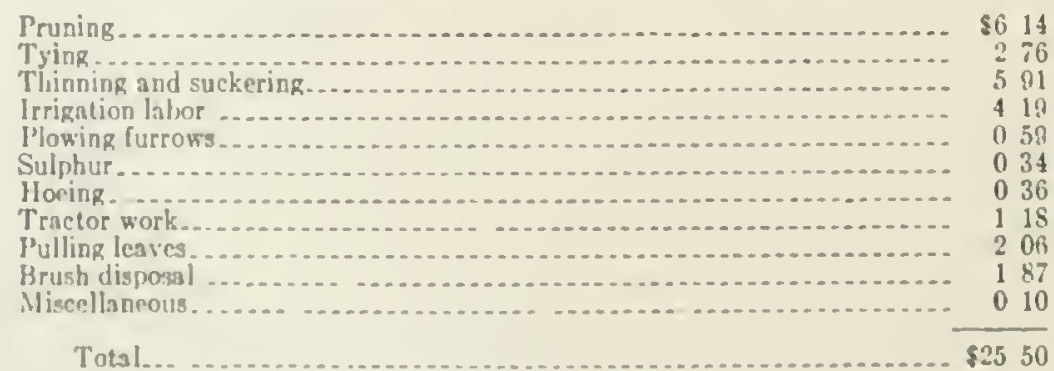

In aldition to the alove, 120 tons were unade into raisins at a cost per ton of $\$ 13.70$ for pieking, turning and laauling. 


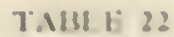

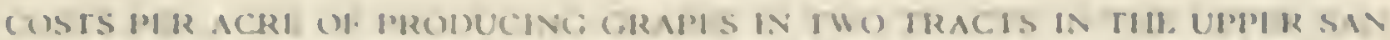

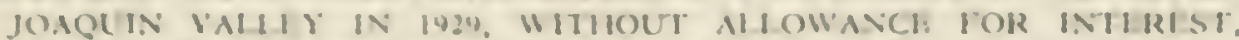
IRRICAIION WAILR, IUUIIIIVT, OKR FIXII) CIIARCIS

Moce!laseure ranetiea

\begin{tabular}{|c|c|c|}
\hline Ileat & 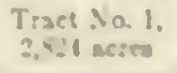 & $\begin{array}{l}\text { Trmet No. : } \\
1.540 \text { serm }\end{array}$ \\
\hline 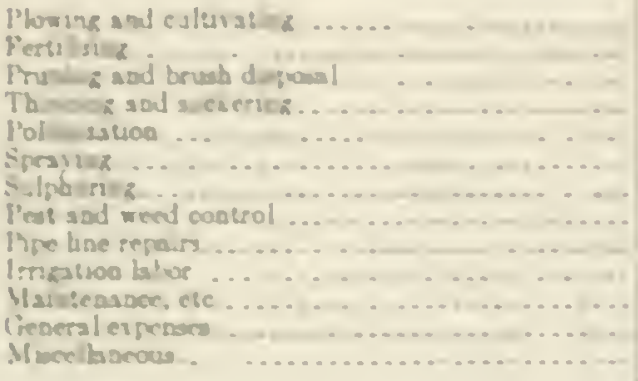 & $\begin{array}{rr}1 & 13 \\
0 & 33 \\
11 & 45 \\
0 & 00 \\
0 & 00 \\
0 & 15 \\
5 & 25 \\
3 & 60 \\
0 & 34 \\
10 & 31 \\
1 & 63 \\
1 & 10 \\
1 & 65\end{array}$ & $\begin{array}{ll}1, & 03 \\
1 & 18 \\
1: & 30 \\
3 & 70 \\
0 & 31 \\
0 & 04 \\
3 & 013 \\
0 & 70 \\
0 & 03 \\
9 & 25 \\
0 & 31 \\
11 & 16 \\
1 & 91\end{array}$ \\
\hline - $\ldots \ldots \ldots$ & Ijis os & 15504 \\
\hline
\end{tabular}

TABLE: :J

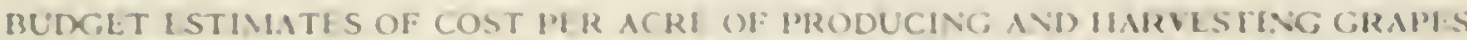

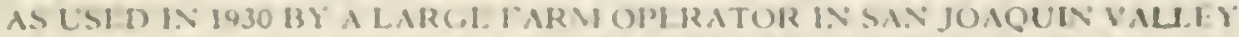
WITHIOUT M.IOW ANCI IOR INTIREST, IOTHI CIATION (D) VINTS OR IRIRICA TION WATIR

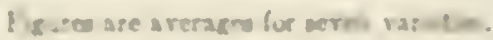

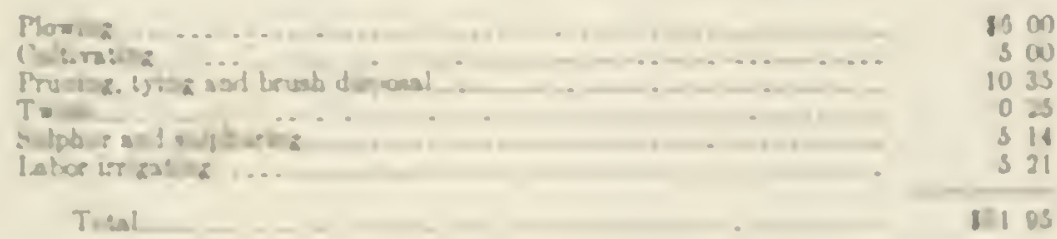

T N13! : :

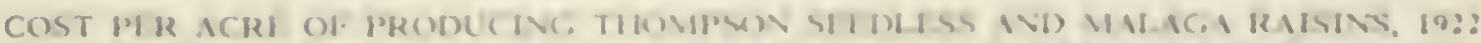

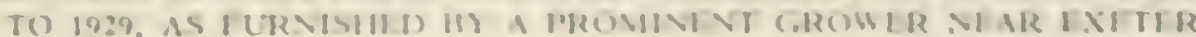

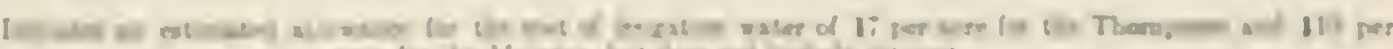

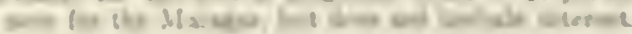

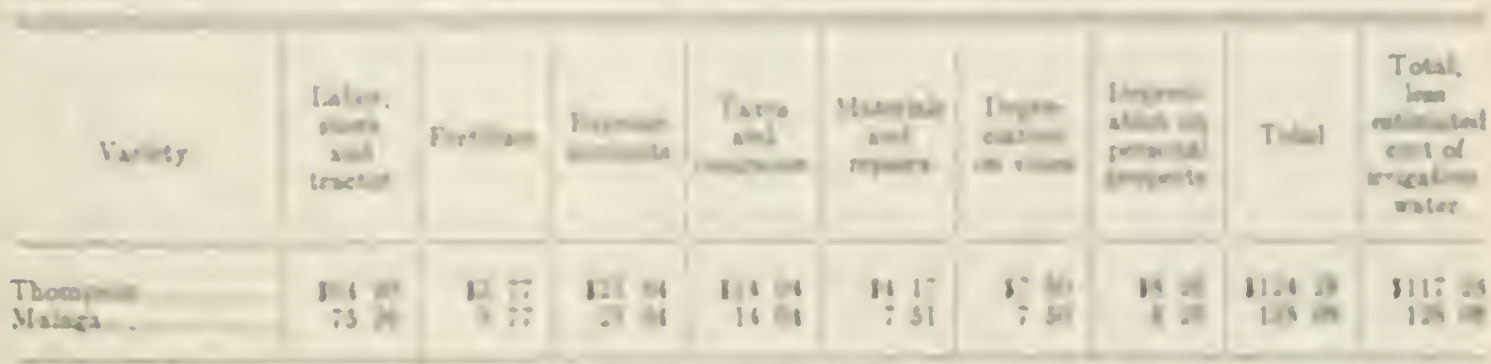

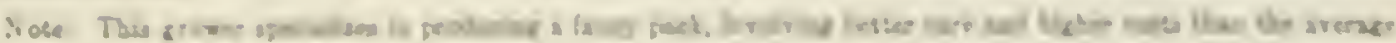


TABLE 25

SUMMARY OF PRE-HARVEST COSTS PER ACRE OF PRODUCING GRAPES, WITI DEPRECIATION ON VINES AND OTHER FIXED CHARGES ADDED AT THF RATE OF \$15.14 PER ACREI WHERE NOT ALREADY INCLUDED

\begin{tabular}{|c|c|c|c|}
\hline Table number & Amount & Table number & Amount \\
\hline $\begin{array}{l}20 \\
21, \text { tract } 1 \\
22, \text { tract } 2\end{array}$ & $\begin{array}{rr}\$ 56 & 89 \\
40 & 64 \\
70 & 79 \\
83 & 18\end{array}$ & 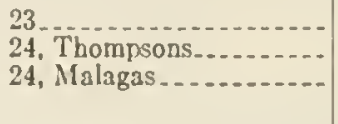 & $\begin{array}{l}\$ 1709 \\
11728 \\
12908\end{array}$ \\
\hline
\end{tabular}

The average shown by 101 agrieultural extension service records as given in Table 19 .

'The wide range in pre-harvest eosts shown in Table 25 might seem to indicate that it is impossible to arrive at a figure representative of the industry. However, as already pointed out, the figures given in Table 25 and in the tables from which they are taken are not strictly comparable. It is the eonclusion that the report ean most safely proeeed on the basis of the 101 Agricultural Extension Service records. the average of which has been sliown to be $\$ 48.40$ an aere for preharvest eosts, including fixed eharges, but without allowance for interest or irrigation water.* The range for these 101 records was from $\$ 30.99$ to $\$ 82.79$ an acre.

It is recognized that there is a certain weather risk in liarvesting grapes for which allowance needs to be made, but no data are available for evaluating it. In view of this risli a pre-luarest eost of $\$ 50$ an acre has been arbitrarily assumed.

\section{Income from Grapes and Amount Available for Irrigation Water Charges.}

It previously has been stated that grapes are harvested as table grapes, raisins, and juice grapes, some varieties being sold under all three of these elasses. It does not seem necessary in the present study to attempt to use more than one elass in arriving at permissible irrigation water charges. The class elosen is raisins, sinee the largest part of the upper San Joaquin grape crop is disposed of in this form.

Basing the study of permissible irrigation water eharges for grapes on raisins might be considered by some to be too conservative, since table and juice grapes have generally been bringing higher returns. Ilowever, the stabilization plans recently adopted for the entire grape industry in California, and the tendency towards equalization in prices for the varieties sold under all three elasses, seem to warrant basing the analysis on laisin mapes only. Plate III, talien from California Agrivultural Fixperiment Station Bulletin 429.t page 92, shows the trent of purchasing power of the varions elasses over a ten-year period.

After consiblering the results of his studies extending over several years, it is the judement of the Farm. Advisor of 'T'ulare Comnty that a saffe fienre to use for liarvestine a two-ton erop of raisins would be \$15 a ton and for a one-ton crop. \$17 a ton, and he has suggested that an average figure of $\$ 16$ a ton be arfopted. On the basis of this figure and the assmmed pre-halvest cost of thon an acre previously referred to,

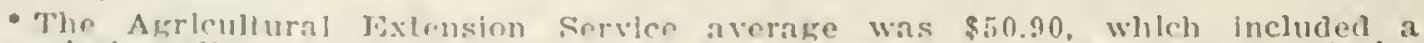
depreclation allowner nn vines of $\$ 10$ an nere per annum, whereas the depreclation allowance In this report is $\$ 5.50$ an acre juc aunum.

+ Shrar. S.W. and Cinuld. I. 1\%. licomomlc Status of the Grape Industry, Callfornla Agr. Exp. Sin. Bul. 129, p. 2. 
PUATE III

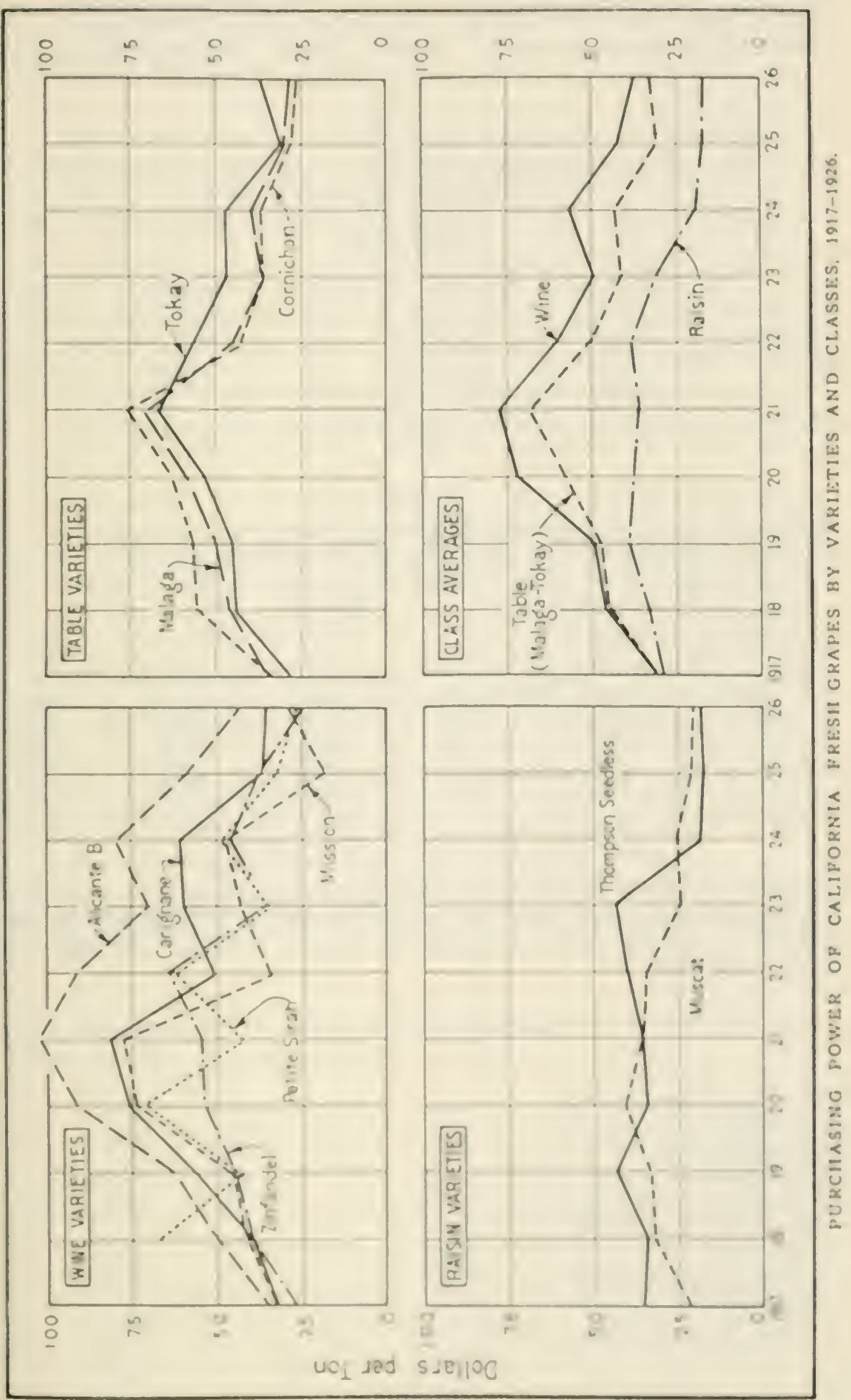


Table 26 has been prepared to show the avelage eost per acre of produeing and harvestine rasins in the upper San .Joaquin Valley, and Table 27 his beren preprited to show the ineome per acre with yields of .75 to 2.25 toms per acre and a priee range of from $\$ 40$ to $\$ 80$ a ton.

TABLE 26

AVERAGE COST PER ACRE OF PRODUCING AND HARVESTING RAISINS
IN THE UPPER SAN JOAQUIN VALLEY

Pre-harvest cost taken at $\$ 50$ an aere: Harvesting figured at $\$ 16$ a ton and no allowance ineluded for interest or for irrigation water.

\begin{tabular}{|c|c|c|c|}
\hline $\begin{array}{l}\text { Yield, in tons } \\
\text { per aere }\end{array}$ & $\begin{array}{c}\text { Average eost } \\
\text { per acre }\end{array}$ & $\begin{array}{l}\text { Yield, in tons } \\
\text { per acre }\end{array}$ & $\begin{array}{l}\text { Average eost } \\
\text { per acre }\end{array}$ \\
\hline $\begin{array}{l}0.75 \\
1.00 \\
1.25 \\
1.50\end{array}$ & $\begin{array}{rr}\$ 62 & 00 \\
60 & 00 \\
70 & 00 \\
74 & 00\end{array}$ & $\begin{array}{l}1.75 \\
2.00 \\
2.25\end{array}$ & $\begin{array}{rl}\$ 78 & 00 \\
82 & 00 \\
80 & 00\end{array}$ \\
\hline
\end{tabular}

TABLE 27

INCOME PER ACRE TO GROWERS FROM RAISINS WITH YIELDS OF 0.75 TO 2.25 TONS PER ACRE AND A PRICE RANGE OF \$40 TO \$80 PER TON

\begin{tabular}{|c|c|c|c|c|c|}
\hline \multirow{2}{*}{$\begin{array}{l}\text { Pield per aere, } \\
\text { tons }\end{array}$} & \multicolumn{5}{|c|}{ Price per ton } \\
\hline & 840 & $\$ 50$ & $\$ 60$ & sio & $\$ \$ 0$ \\
\hline $\begin{array}{l}0.75 \\
1.00 \\
1.25 \\
1.50 \\
1.75 \\
2.00 \\
2.25\end{array}$ & 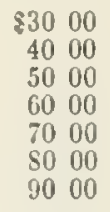 & $\begin{array}{rr}\$ 37 & 50 \\
50 & 00 \\
62 & 50 \\
75 & 00 \\
87 & 50 \\
100 & 00 \\
112 & 50\end{array}$ & 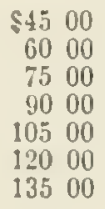 & $\begin{array}{rr}\$ 52 & 50 \\
70 & 00 \\
87 & 50 \\
105 & 00 \\
122 & 50 \\
140 & 00 \\
157 & 50\end{array}$ & $\begin{array}{r}\$ 6000 \\
8000 \\
10000 \\
12000 \\
14000 \\
16000 \\
18000\end{array}$ \\
\hline
\end{tabular}

Fields.-Figures reguding average rields of raisins per aere in the upper San . Ioaquin Valley are not arailable for long periods or large acreages. Agrieultural Extension Service Cireular 24 gives the following data :

\begin{tabular}{|c|c|c|c|}
\hline & 1926 & 1927 & 1928 \\
\hline 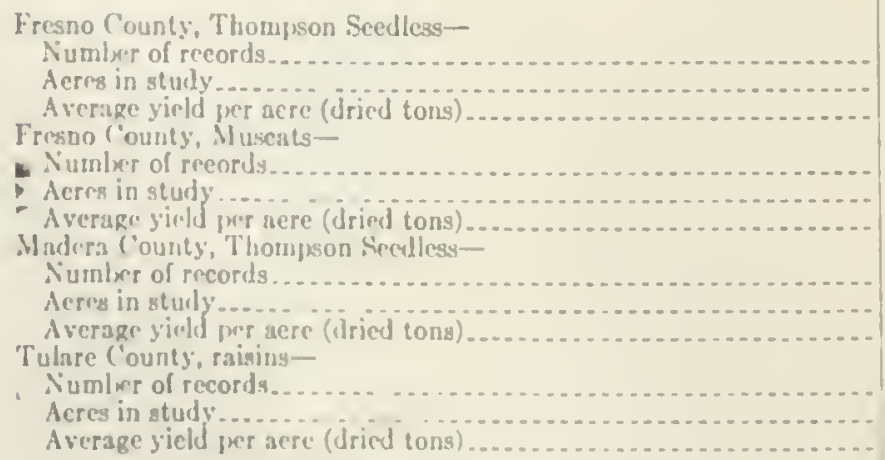 & $\begin{array}{c}24 \\
4 S 2.3 \\
1.71 \\
0 \\
350.2 \\
1.47\end{array}$ & 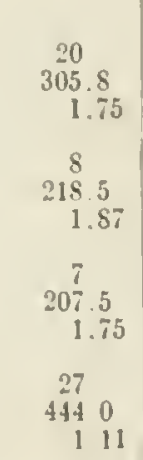 & 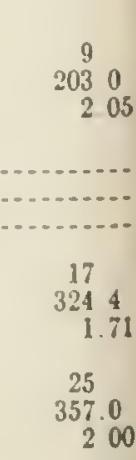 \\
\hline
\end{tabular}




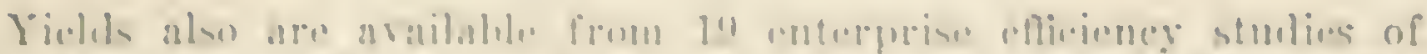

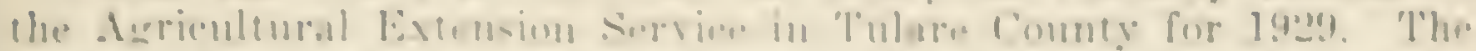

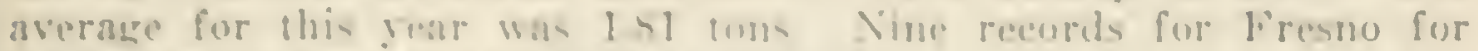

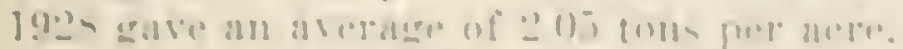

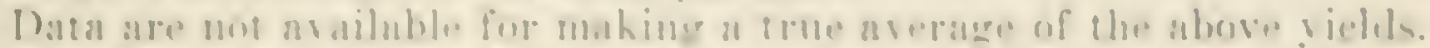

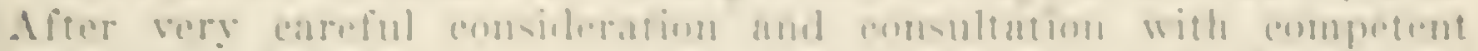

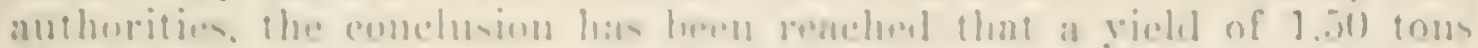

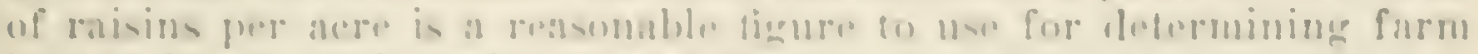

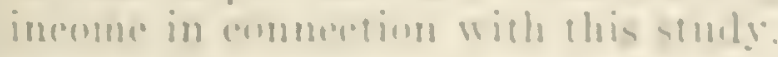

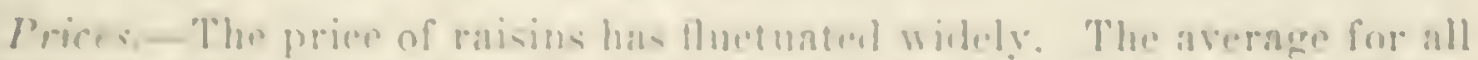

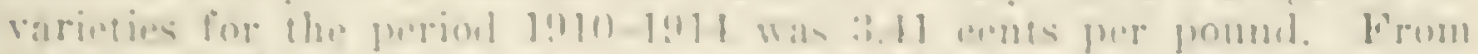

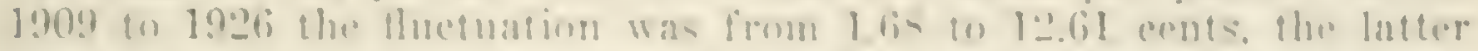

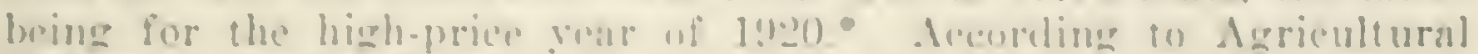

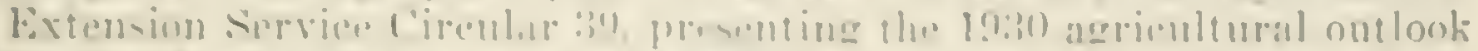

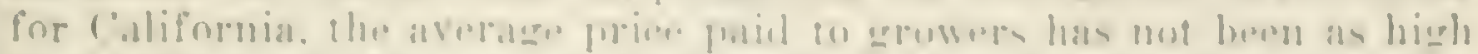

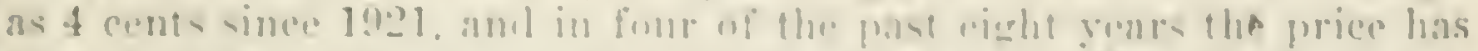

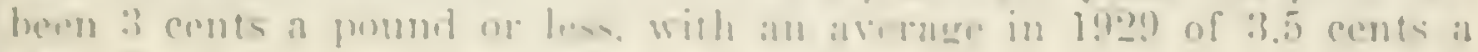
poums!.

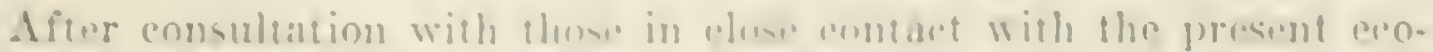

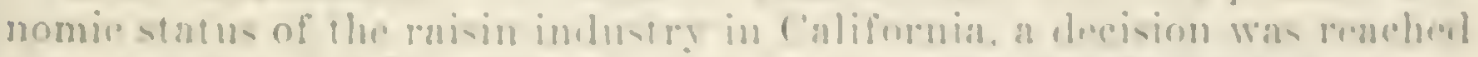
that a price of 3.25 cents a pumbl is the mont sativfactory figure in

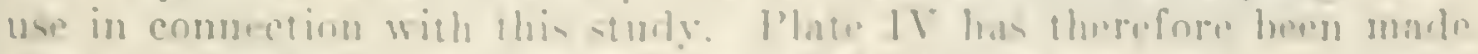

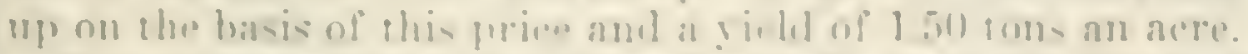

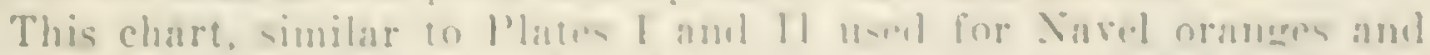

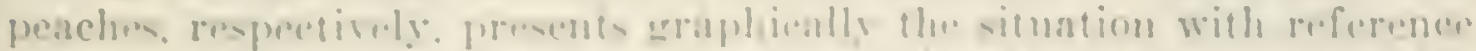

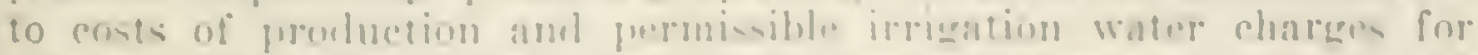

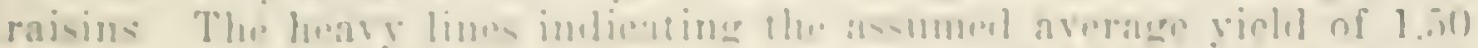

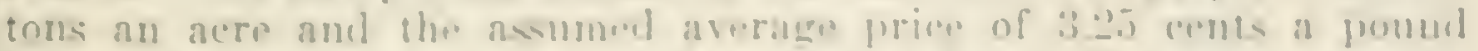

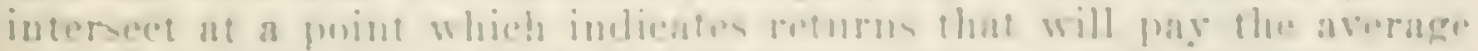

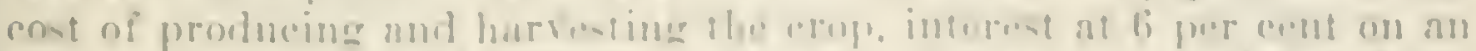

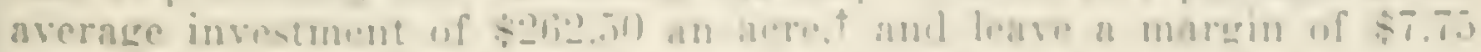

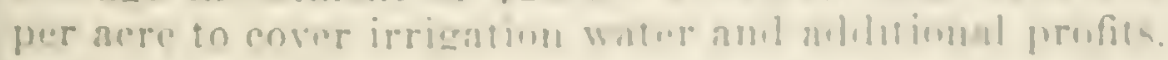

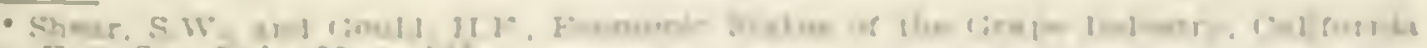

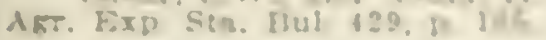

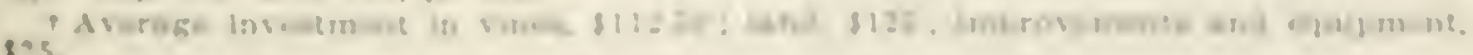


PLATE IV

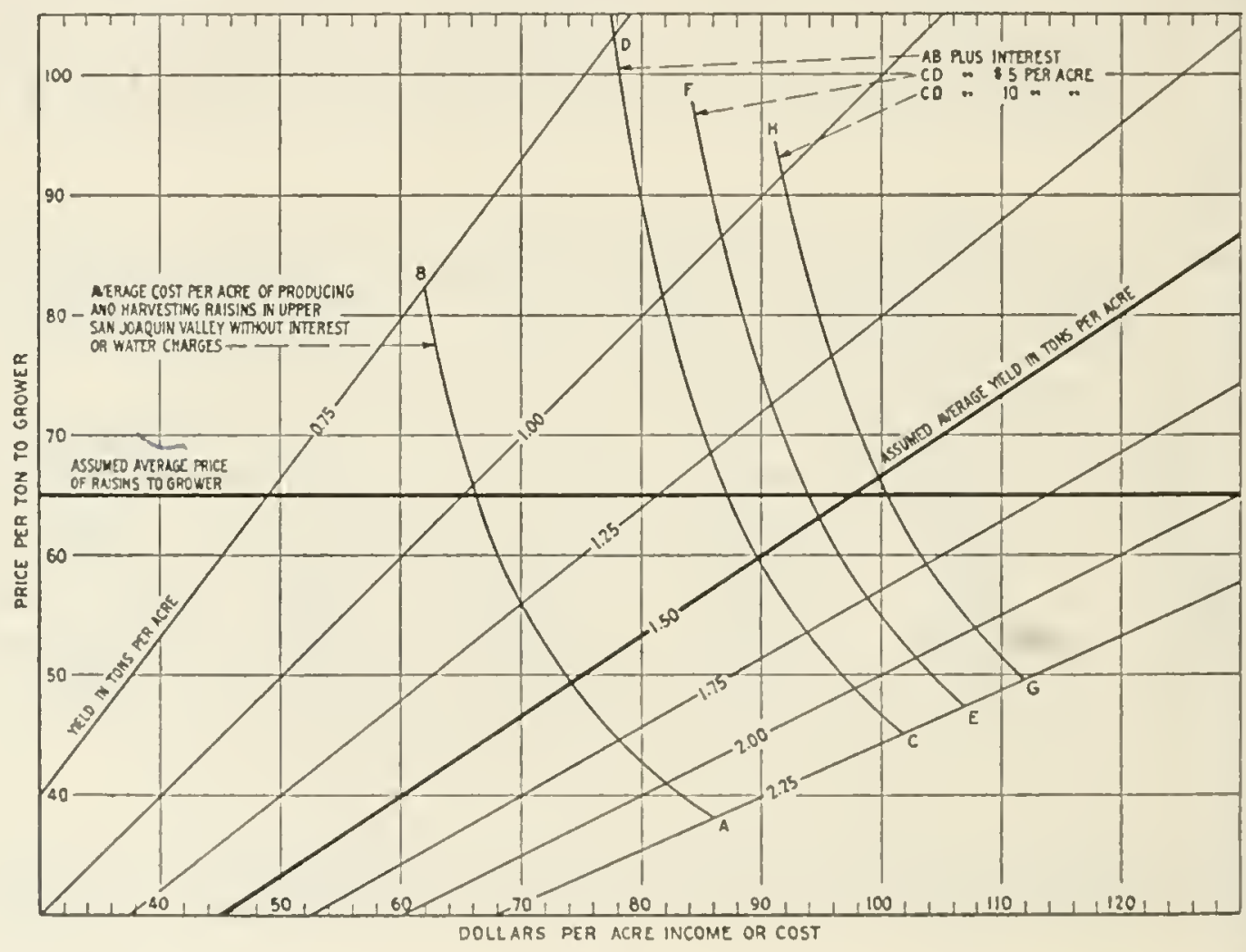

RELATION BETWEEN COST OF PRODUCING AND HARVESTING RAISINS AND FARM INCOME. 


\section{('11.1P'Tl\% li}

\section{Costs of Production.}

\section{ALFALFA}

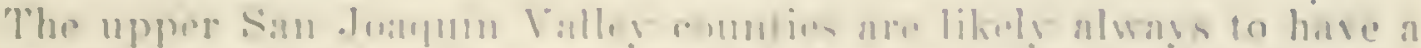

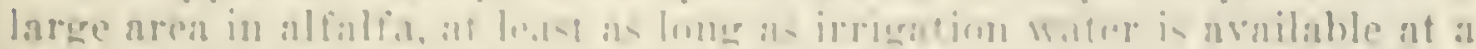

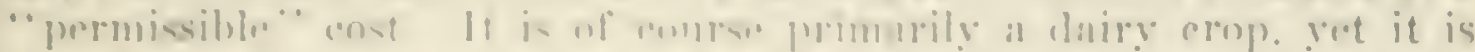

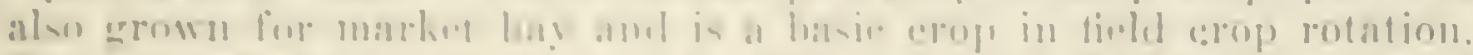

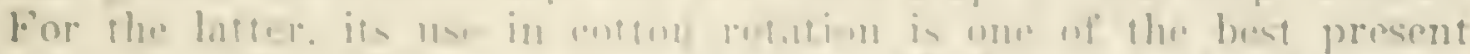

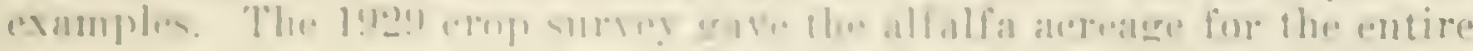

| |III| !4

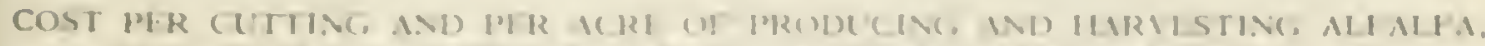

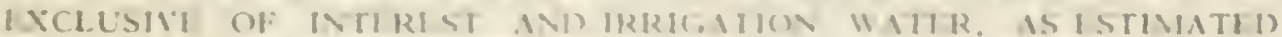
FR(II I.XI' RII प(1 . IVI)

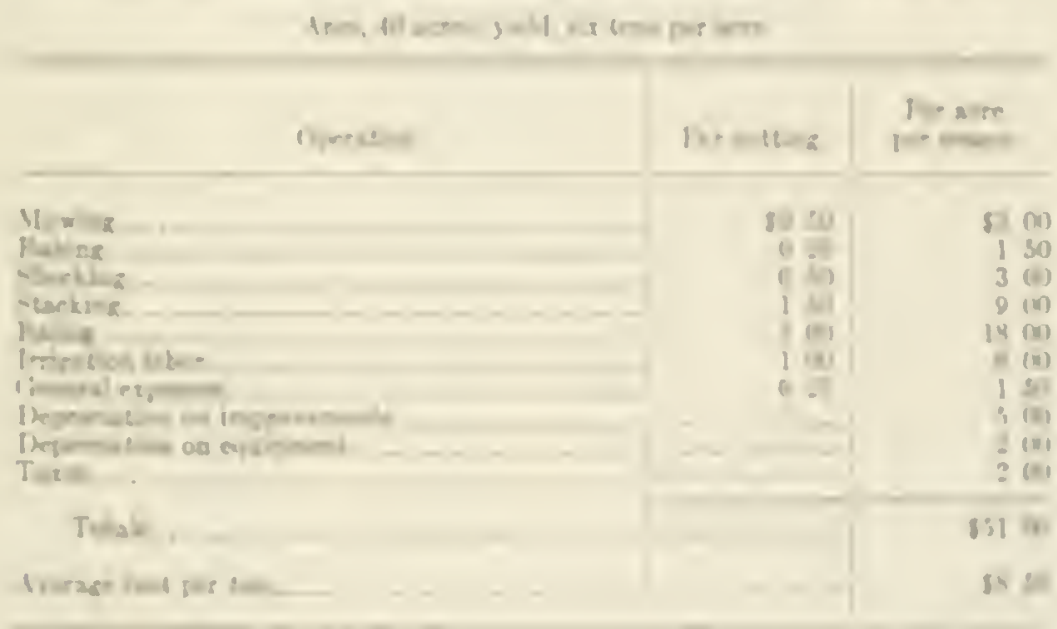

IIIII:T

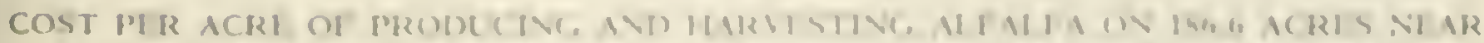

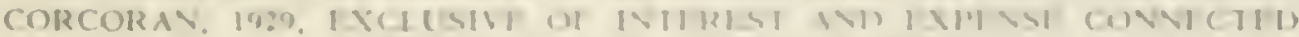

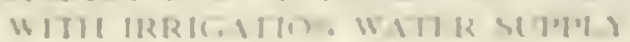

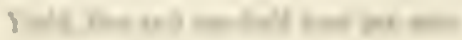

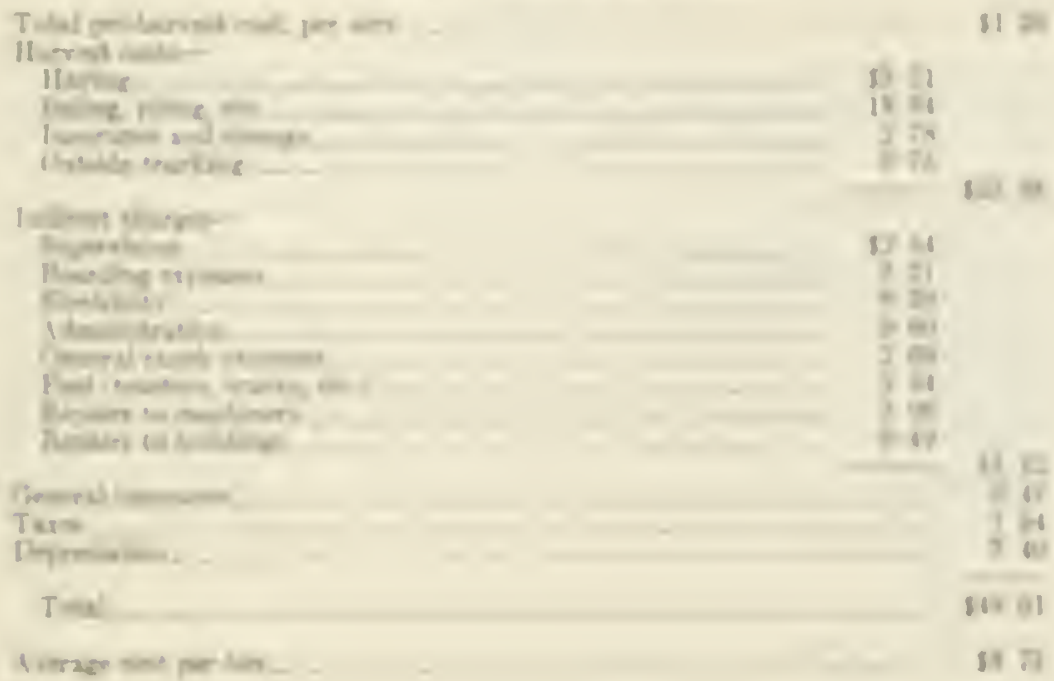


San Joaquin Valley as 403,270, the acreages in the four upper counties being Fresno, 54,830; 'Tulare, 54,663 ; Kel’n, 30,422 ; Kings, 21,209.

Cost-of-production data were not available from the Agricultural Extension Service, except for Merced Comnty for 1926-28, and Imperial Comnty for 1928. Some specific data on this erop were, however, cbtained during the field study in the mpper counties, and the estinates of the Farm Management Section have been made available. Furthermole, alfalfa eosts are perhaps more generally known than are the costs for other crops.

Tables 28 to 31 present the data used in arriving at the conelusions given.

TABLE 30

COST PER ACRE OF PRODUCING AND HARVESTING ALFALFA IN IMPERIAL COUNTY, 1928, AND IN MERCED COUNTY, 1926-28, EXCLUSIVE OF INTEREST ON INVESTMENT, BUT INCLUDING INTEREST AND DEPRECIATION ON IMPROVEMENTS AND EQUIPMENT AND COST OF IRRIGATION WATER

Data from Agrieultural Extension Service eireular 24.

\begin{tabular}{|c|c|c|c|c|}
\hline & $\begin{array}{l}\text { Imperial } \\
\text { County }\end{array}$ & \multicolumn{3}{|c|}{ Merced County } \\
\hline & 1928 & 1926 & 1927 & 1928 \\
\hline $\begin{array}{l}\text { Number of records } \\
\text { Acres in study } \\
\text { Average yield per aere, tons }\end{array}$ & $\begin{array}{r}4 \\
265 \\
4.27\end{array}$ & $\begin{array}{r}5 \\
133 \\
5.16\end{array}$ & $\begin{array}{r}15 \\
309 \\
5.44\end{array}$ & $\begin{array}{l}4 \\
61 \\
6.42\end{array}$ \\
\hline $\begin{array}{l}\text { Average eost per aere- } \\
\text { Labor } \\
\text { Materials (ineluding water) } \\
\text { Cost, overhead } \\
\text { Interest and depreciation (jneludiag irrigation } \\
\text { equipment) }\end{array}$ & $\begin{array}{r}\$ 2874 \\
634 \\
504 \\
1199\end{array}$ & $\begin{array}{r}\$ 23 \\
810 \\
385 \\
852\end{array}$ & $\begin{array}{rr}\$ 2 & 72 \\
5 & 77 \\
3 & 79 \\
13 & 04\end{array}$ & $\begin{array}{rr}\$ 24 & 16 \\
11 & 90 \\
3 & 65 \\
11 & 75\end{array}$ \\
\hline Total costs per sere & $\$ 5211$ & $\$ 4430$ & $\$ 4532$ & $\$ 5146$ \\
\hline $\begin{array}{l}\text { Total costs per aere, less an assumed averagc water } \\
\text { charge of } \$ 5 \text { per aere* }\end{array}$ & $\$ 4711$ & $\$ 3930$ & $\$ 4032$ & $\$ 4640$ \\
\hline Average eost per ton, less assumed water charge.... & $\$ 1103$ & 5761 & $\$ 741$ & $\$ 724$ \\
\hline
\end{tabular}

*There is still left interest on improvements and equipment other than that used for irrigation water.

TABLE 31

COST PER ACRE OF PRODUCING AND HARVESTING ALFALFA IN THE SAN JOAQUIN VALLEY AS ESTIMATED BY TIIE FARM MANAGEMENT SECTION OF TIHE COLLEGE OF AGRICULTURE

Docs not Inolude interest on land or cost of irrigation water; yield six tons in six euttings.

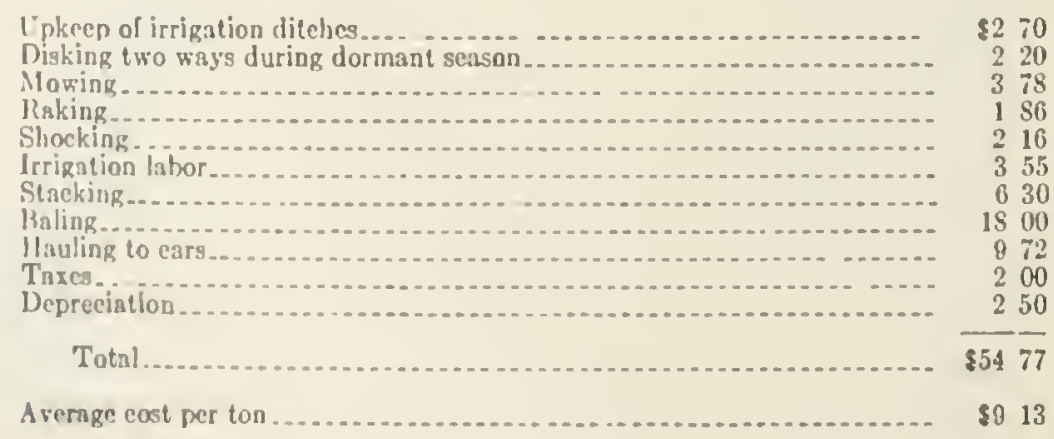




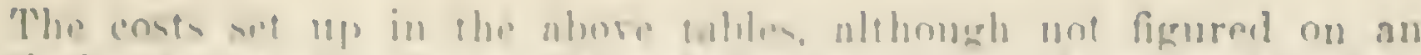

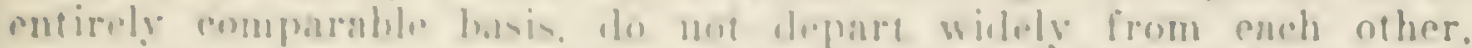

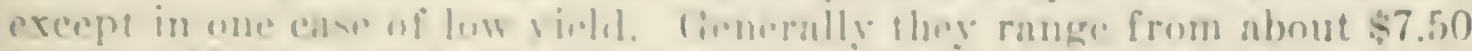

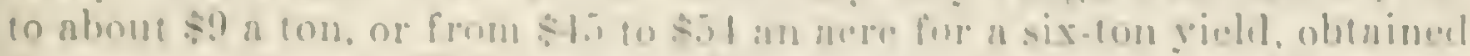

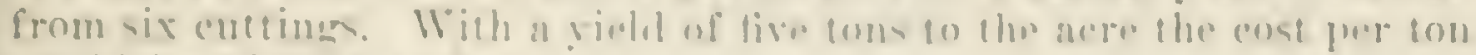
wombl be slighty higher.

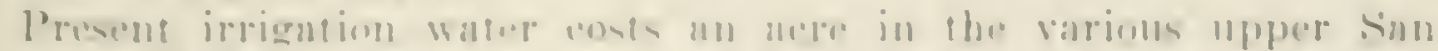

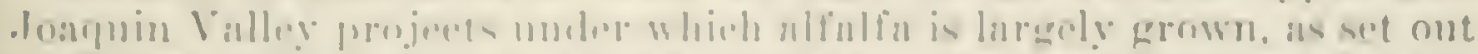

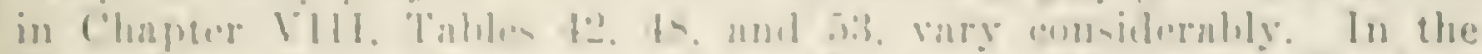

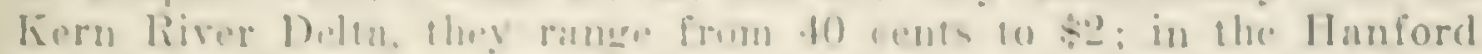

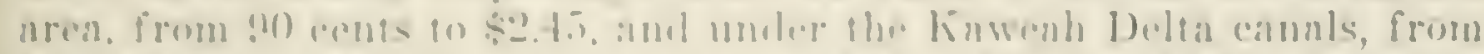

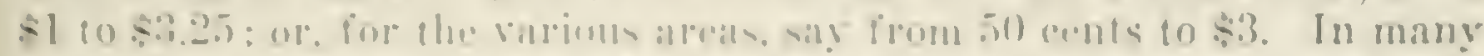

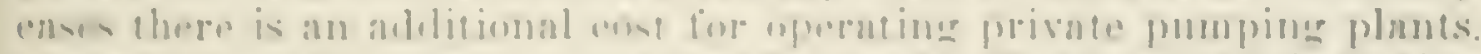

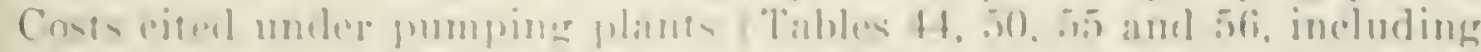

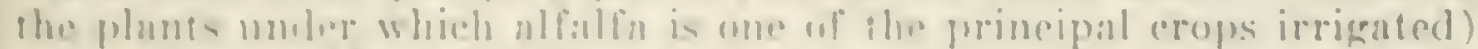

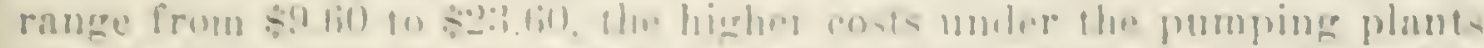

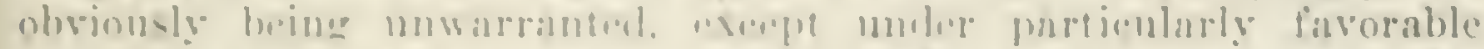

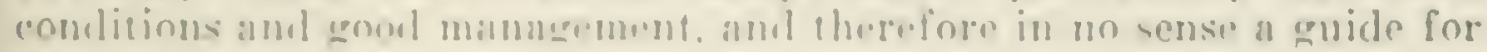
project planuing.

\section{Income from Alfalfa and Amount Available for Irrigation Water Charges.}

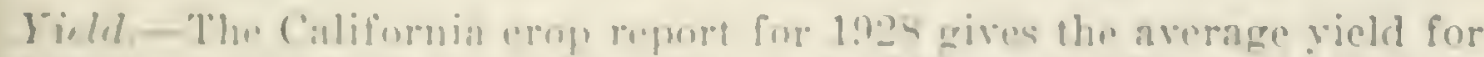

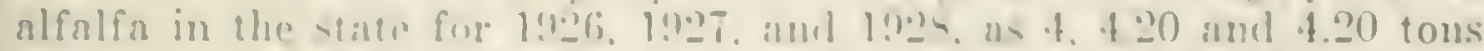
for aere, revgmelively. This is much helow a normal vield on good

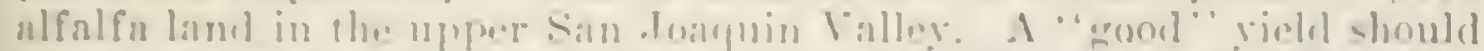
be at least six fous pror acre. hut a violel of fivo fous is eomsidered as

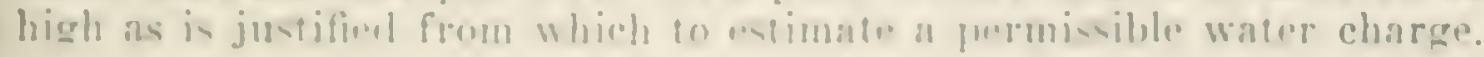

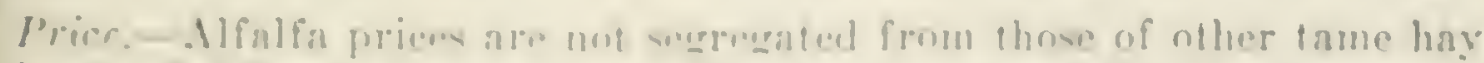

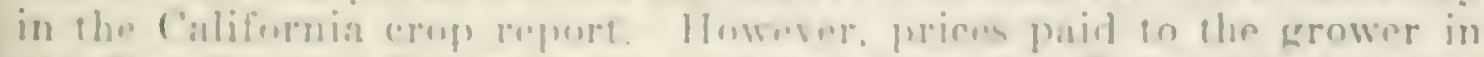

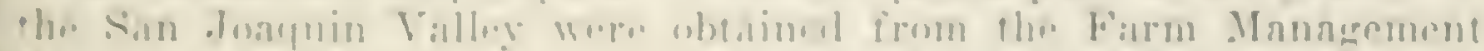

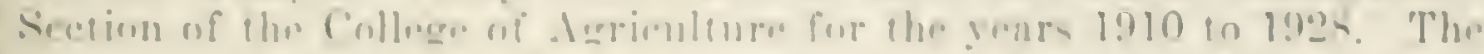

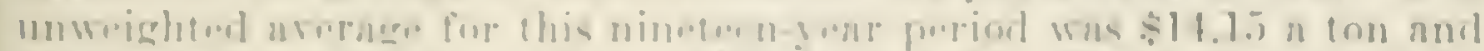

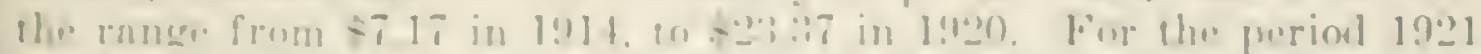

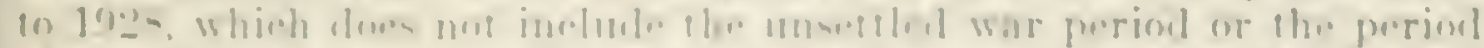

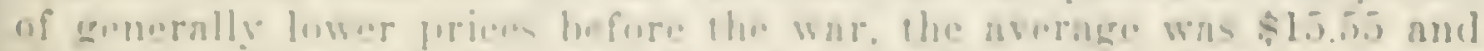

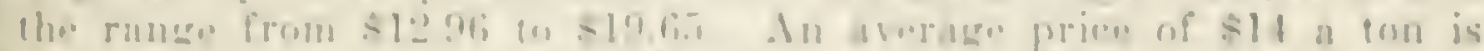

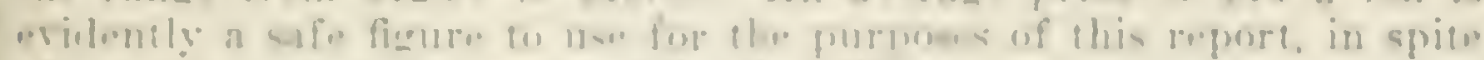

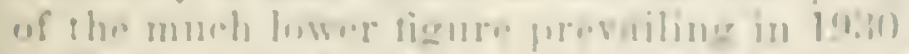

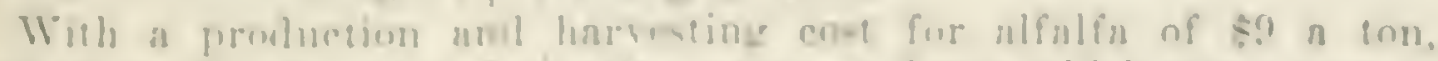

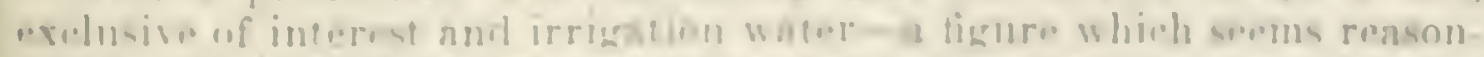

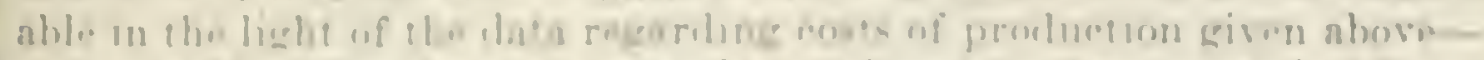

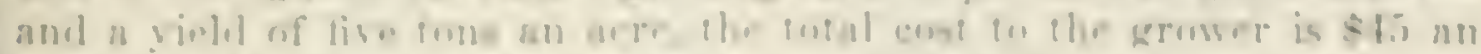

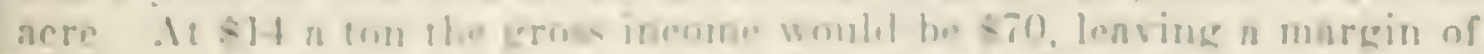

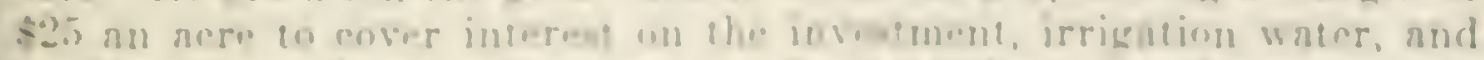

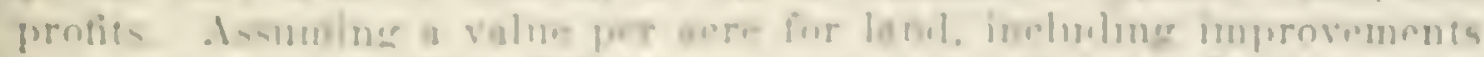

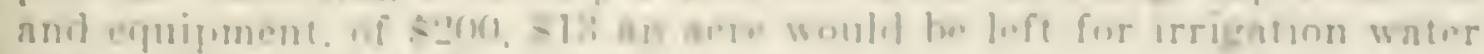
and arditional profits. 


\section{CHAPTER VTI}

\section{ANNUAL CROPS}

Grain.

The erop survey for 1929 made by the State Engincer's office showed 102.000 aeres of arain in the three upper San Joaquin Valley counties. 'his was divided between Tulare Comuty with 10.089 acres, Kings County with 5.3.310 acles, and Kom Comty with 38,80.5 acres. There is some dry-famed grain, but from the standpoint of the present study the industry is of chief importance in: the 'lulare Lake area. where all of the grain is irrigated. There is some grain irrigated from pumping on the west side in Fresno County, but otherwise, nutside of the Tulare Lake area. gram is irrigated in the upper San .Joaquin Valley only where watel is available muder araty ditehes. or from relatively low pumping lifts, or where the grain is grown ineidentally with other crops and is ilrigated only to fill in the pumping load and only the cost of power is charged to the grain. So far as grain is eoneerned, the present inquiry lias therefore been eonfuned to the Tulare Lake area. In this report the grain referred to is chiefly wheat and barley.

Grain growing in the Tulare Lake Basin is condueted on large acreares. Cost-of-production data gathered for the report were obtained for approximately 18,000 areses, in holdings varying from $30 t$ to 6,950 aeres. In some eases the figures lepresent the growers' general experience, rather than the eosts for a particular year.

The data are not equally complete, but the substance of the material obtained, as far as it can be tabulated. is given in Table 32 . General cost-of-production figures that could not be included in the tabulation were obtained fiom serelal prominent arower's and these were considered in arriving at the enchesions given. No attempt has been made to treat whoat and barley separately.

TABLE 32

COST PER ACRE OF PRODUCING AND IHARVESTING GRAIN ON SEVEN TRACTS IN TULARE LAKE BASIN

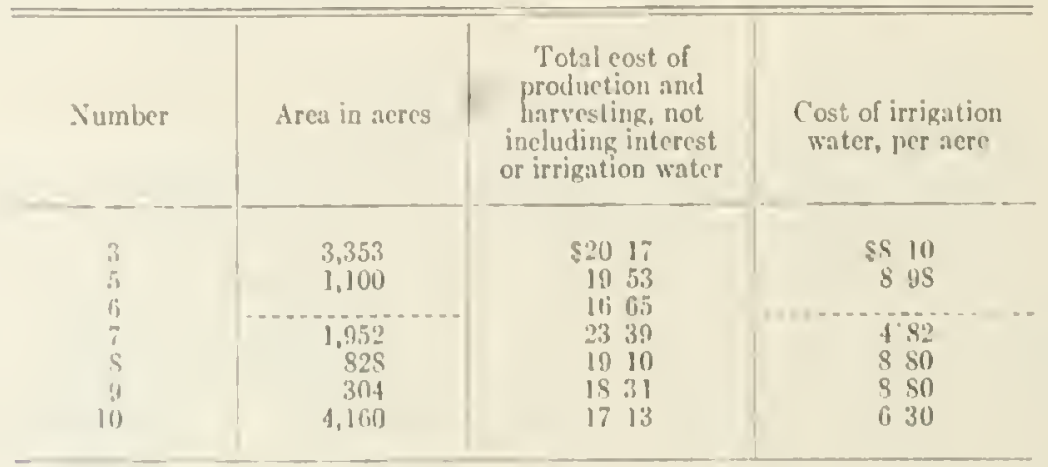

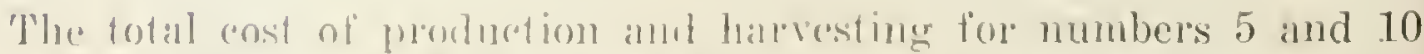

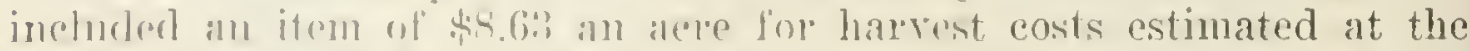

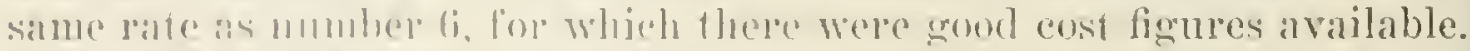

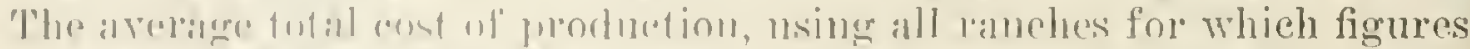

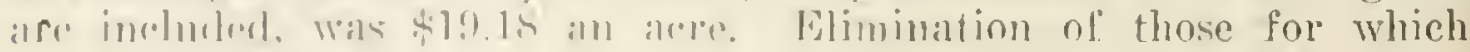




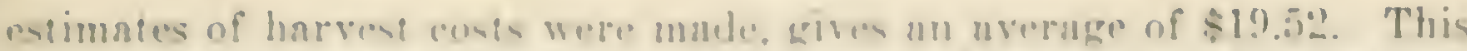

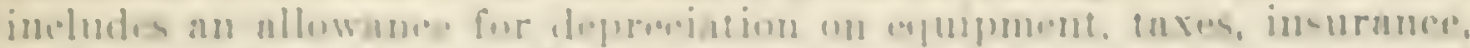

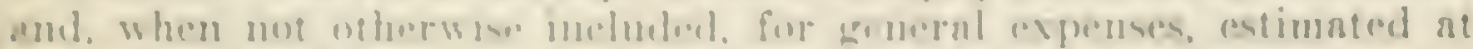

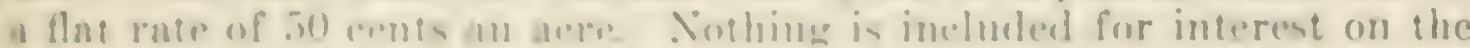

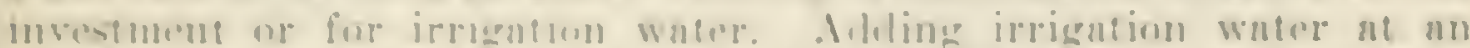

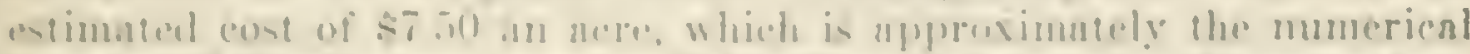

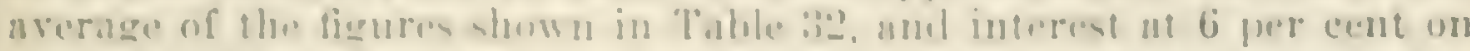
Inud as $\$ 100$ an alere and

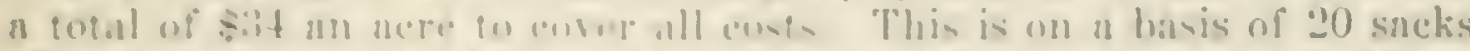
of whent an mere. a vinhl which a mumber of the grower stufed is a far average. This shom a enal ene wi produreing and harbesting

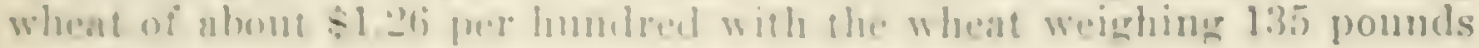
n sack.

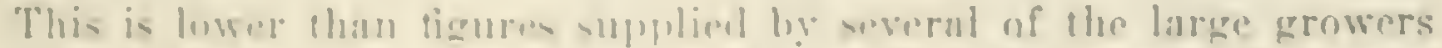

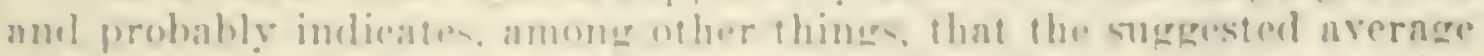

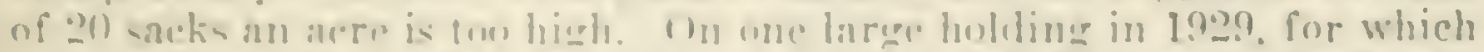

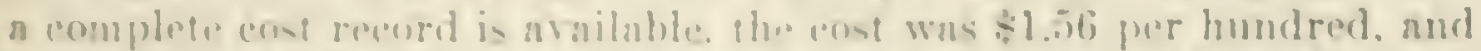

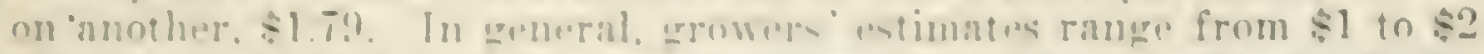

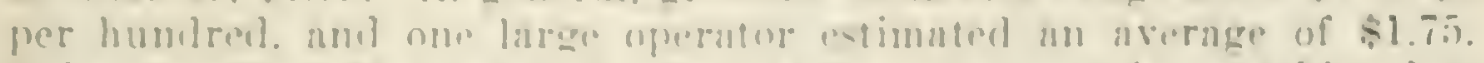

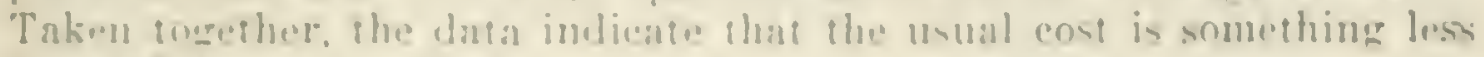
than $\$ 1.75$ per hundred

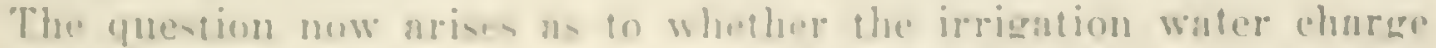

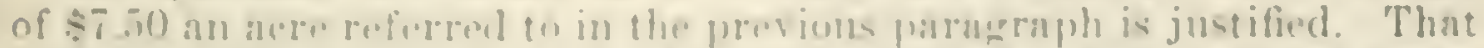

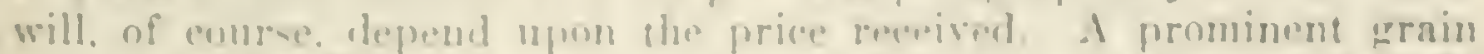

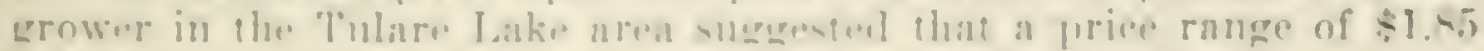

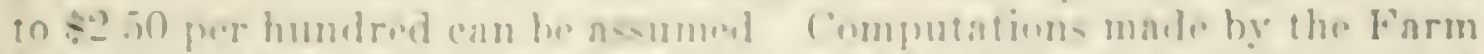

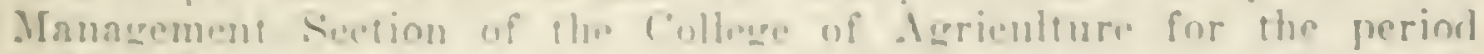

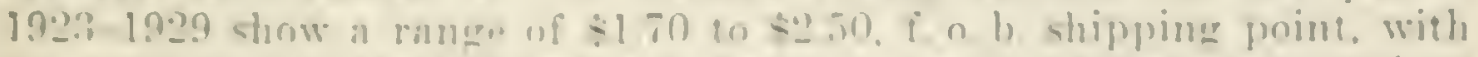

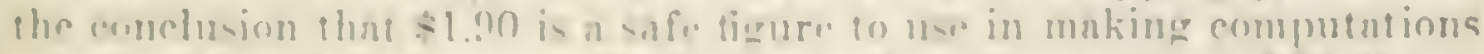

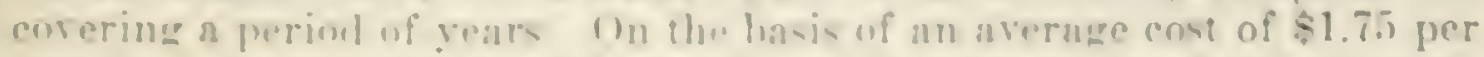

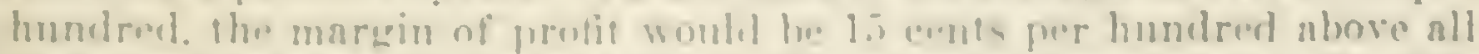

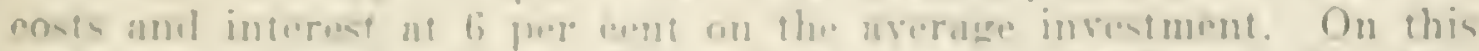

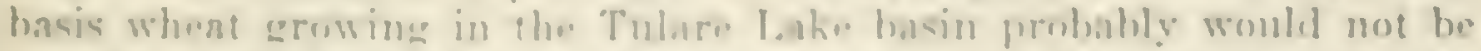

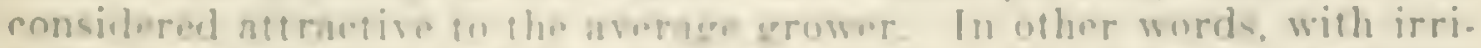

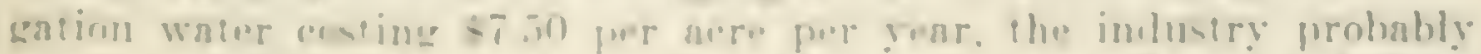

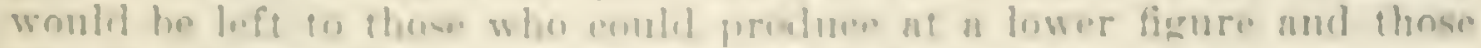

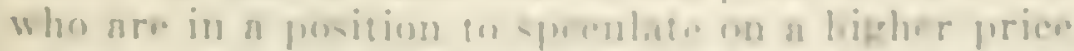

Tahle sol on pre..ent irrigation exass shows a range in enet of waper of

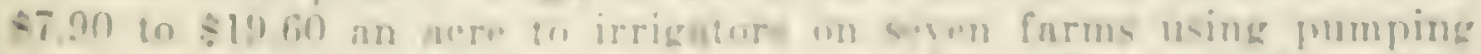

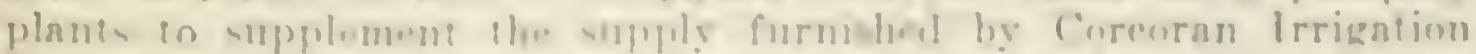

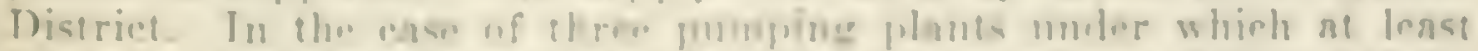

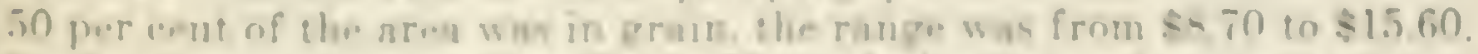

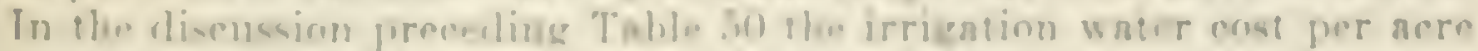

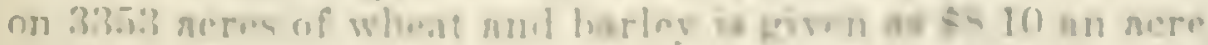

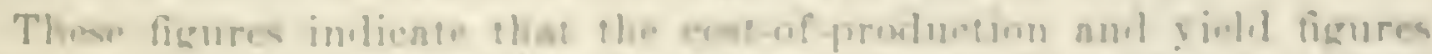

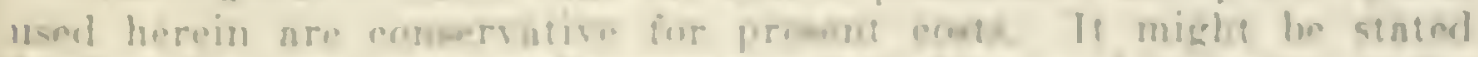

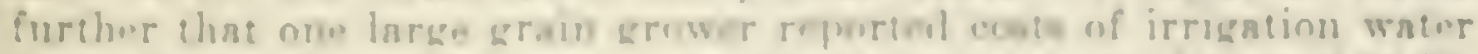

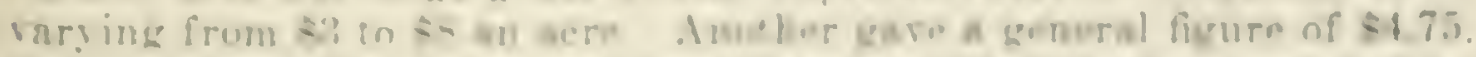

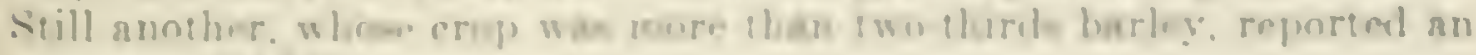
arorago of s- in

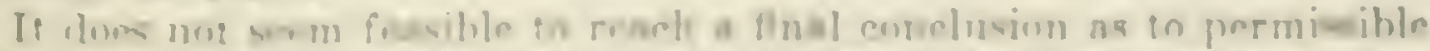

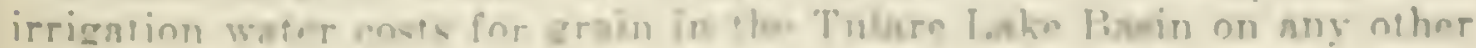


basis than present watel costs and the general conditions which surround grain growing, beeause the data available do not permit of a statistical analysis. While the data indicate the present average cost of water in the Tulare Lake grain section approximates $\$ 7.50$ per aere per vear, this is a higher figure than is considered safe to use for state planning for water importation. Hence an abitraly figure of $\$ 6$ per aere per year is suggested with a full realization that some growers will be able and willing to pay as high as $\$ 8$ or $\$ 10$, but also with a realization that to some $\$ 6$ will be considered a burdensome charge. 'That is approximately 60 per cent of the average pre-harvest cost of producing the crop, not including interest and the water charge, indicated by the records and estimates used herein. It should be remembered, however, that this applies only to the 'Tulare Lake area, where large-scale grain farming is the rule.

\section{Cotton.}

The cotton industry in the San Joaquin Valley, while of recont origin. has come to be an important one, with a total area in 1929, according to the erop survey by the State Engineer's office, of 256,853 acres. The 1929 plantings in the four upper counties, according to the same somrce, were Tulare, 69,534 aeres; Kern, 64,306 acres; Fresno, 60,512 acres; Kings, 22,033 acres.

Despite the generally pessimistic view of the cotton industry in the San Joaquin Valley, taken perhaps mostly by those not growing this erop, the present size of the industry in the valley requires that it be taken into account in any present planning. The long, warm growing season and the farorable soil conditions in portions of the valley result, undel good management, in avelage vields of about one bale to the acre, with better growers expecting 1.5 bales.

Three sources were drawn on for cost-of-production data. These include 22 recolds obtained by the Agricultural Extension Service in Kern County from 1926 to 1929. of which three were for renters and not used; five records for 1929 obtained in the field, and five estimates supplied by large raneh managers. The data are summarized in 'J'able 33.

In that table the estimates of ranch managers are appreciably lower than actual costs obtained from the other somees. Without doubt one of the reasons for this is a lower allowance for depreciation. Another is the gleater cenomy in the larese-seale operations. In the ease of harvest costs, the estimates of the manawers are based on contract prices, this presmmably aceomtine for the eloseress to miformity.

Table ist presents cost-of-punduction and harvesting data as worked up lig the Falu Management Section of the College of Agrienture, the firmers inchuding allowanees for depreciation on work animals and equipment, hut omitting interest and irroination water.

'The figures in Tables $9: 3$ and 34 present sufficient variation to warrant differenees of opinion as to what should be issumed to be average costs.

In the case of both pre-halrest and halvest ensts it will be noticed that. so la as recolods gathered in the field ale enucerued, the figures laken from the derienlumal dixtension Serviee muterprise effieieney studies lie lonfwen the fienures or estimates of raneh managers and those 
INIII! II

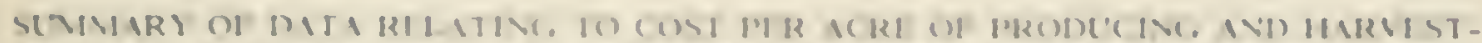

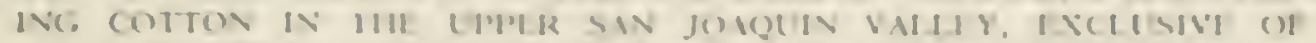

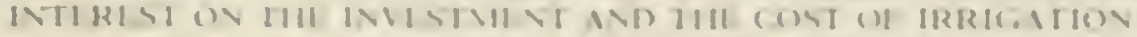

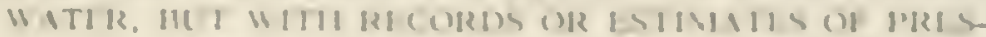

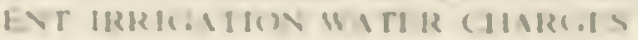

\begin{tabular}{|c|c|c|c|c|c|}
\hline$x-$ of the & 107 ents & 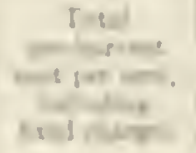 & 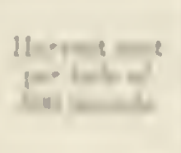 & 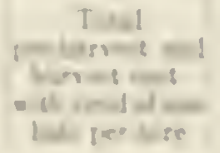 & 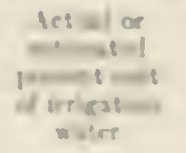 \\
\hline 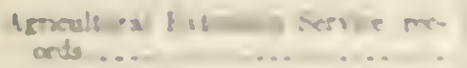 & $78:$ & 11713 & 81.1 & $1: 24$ & $1810=3$ \\
\hline 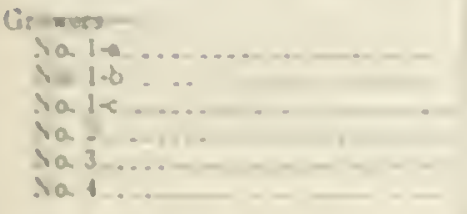 & 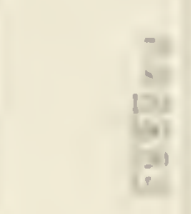 & 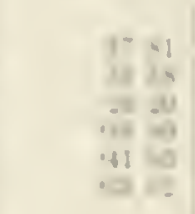 & 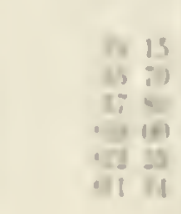 & $\begin{array}{l}\vdots \\
i \\
i\end{array}$ & 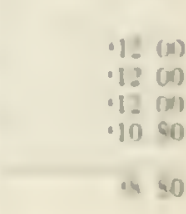 \\
\hline 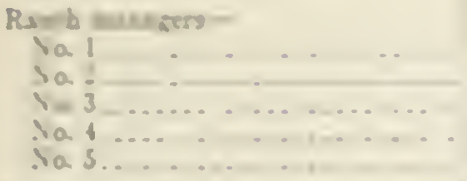 & $\begin{array}{c}--1-- \\
\ldots\end{array}$ & 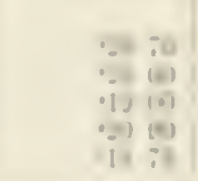 & 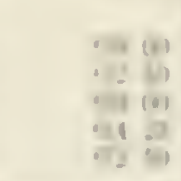 & 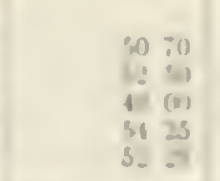 & $-\frac{673}{10(1)}$ \\
\hline
\end{tabular}

Ruare. 9003: \& 51135 a

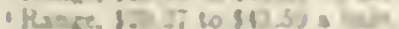

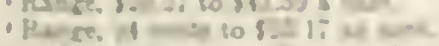

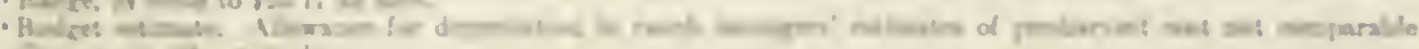

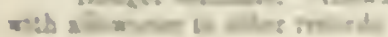

1.

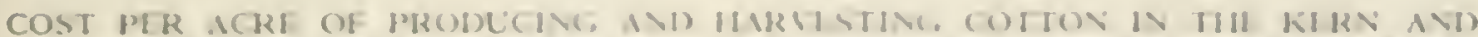

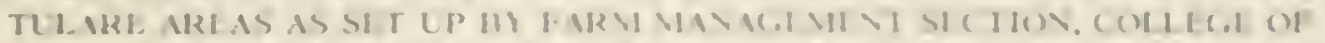

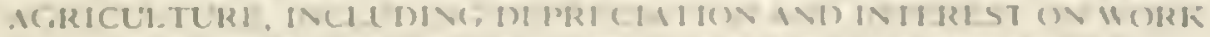

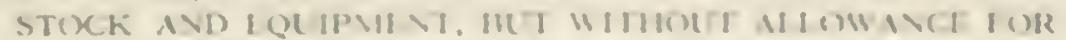

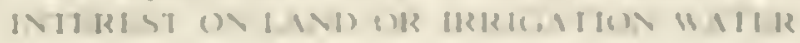

A

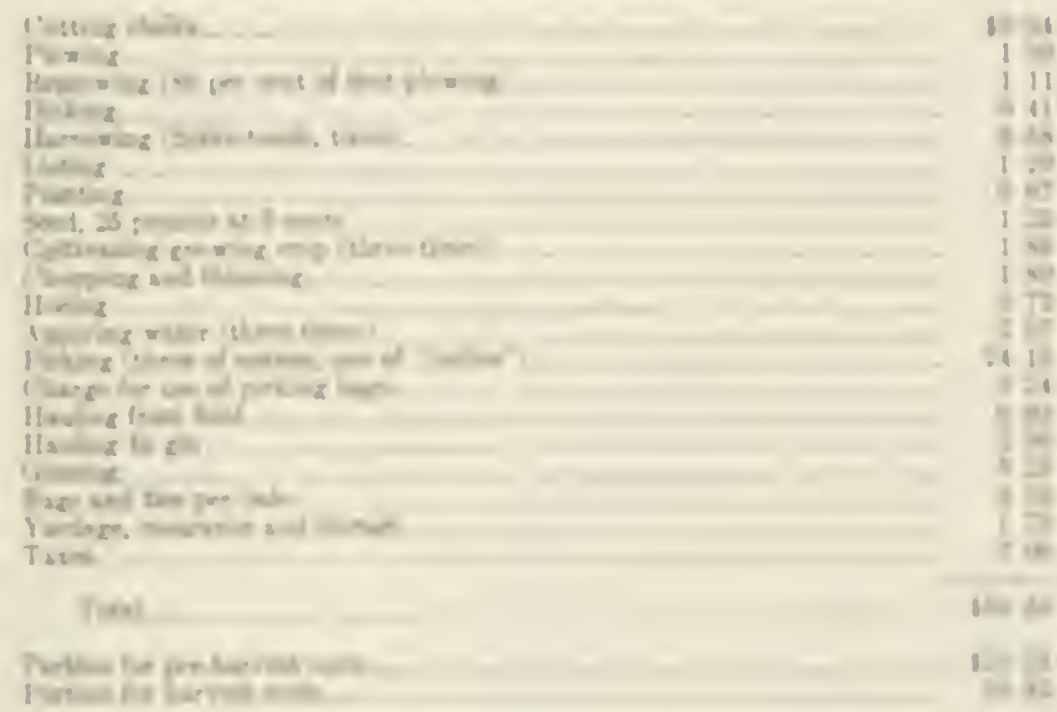

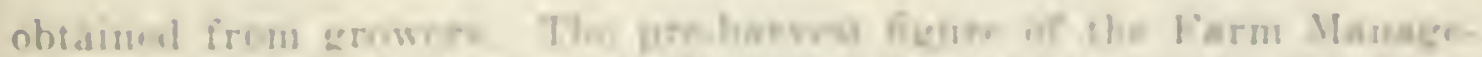

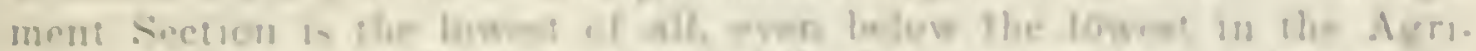

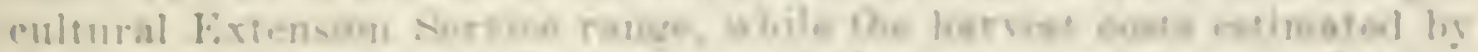

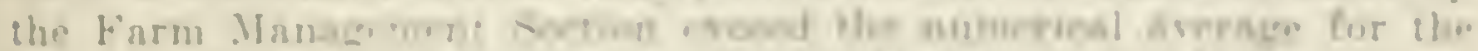

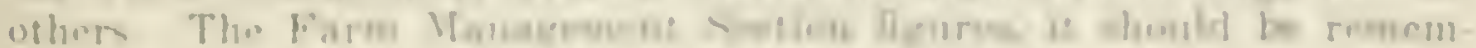


bered. are based on produetive labor neeessary in efficient management, and on larger farm mits than are the basis of the Agrieultural Extension Service costs. They are intended to be applicable only under the particular conditions on whieh they are based and are in no sense set up as an average.

Becanse of the belief that the best lesults in eotton in the future will be obtained by combining it on smaller aereages with alfalfa, and as this probably will result in increasing both costs and yields, a total cost of $\$ 65$ an acre for produeing and harvesting this erop, on a one-bale vield basis, has been arbitrarily assumed. This would involve a slightly higher effieieney than is refleeted in the present Agricultural Extension and large-grower reeords, but a higher cost than that indieated by the figures of the Farm Management Section and the raneh managers' budget estimates. The better growers will have somewhat lower costs, and, as the poorer lands are eliminated, an average of $\$ 65$ per acre should be a safe figure for use in planning water development.

\section{Income from Cotton and Amount Available for Water Charges.}

Yield.-The assumption of an average vield of one bale to the acre in the upper San Joaquin Valley, with the better growers expecting 1.5 bales, has already been referred to. Some growers will not plant land to cotton that will not vield three-quarter's of a bale per aere. Other's place the lower profitable limit at one bale. The lint yield for' cighteen Agrieultural Extension Serviee records available ranged from 0.72 to 2.52 bales to the aere, with a numerical average of 1.35 bales. The unweighted average for the three large-grower records, for which actual eosts, rather than estimates, are available, was 1.20 bales to the acre.

As a basis for estimating permissible irrigation water charges it is concluded that a yield of one bale to the aere is justified, knowing that in times of good priees some land produeing less than that will be planted.

Price.-Table 35 gives the December 1 farm price of cotton in California from 1910 to $192 \mathrm{~s}$. The range is from 7 to 43 cents and the numerieal average is 20.5 cents. The Oetober, 1929, to June, 1930, average was 16.25 eents and the June, 1930, priee was quoted in the field at 12 eents.

TABLE 35

DECEMBER 1 FARM PRICE FOR COTTON IN CALIFORNIA, 1910-1928

\begin{tabular}{|c|c|c|c|}
\hline Year & $\begin{array}{l}\text { l'rice in eents } \\
\text { per pound }\end{array}$ & lear & $\begin{array}{l}\text { Price in cents } \\
\text { per pound }\end{array}$ \\
\hline 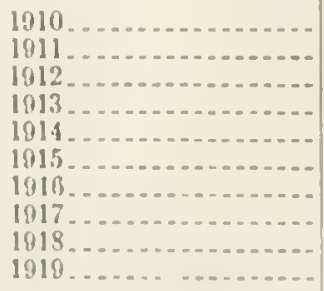 & $\begin{array}{r}13.3 \\
7.5 \\
12.5 \\
13.0 \\
7.0 \\
11.2 \\
200 \\
28.0 \\
30.0 \\
430\end{array}$ & 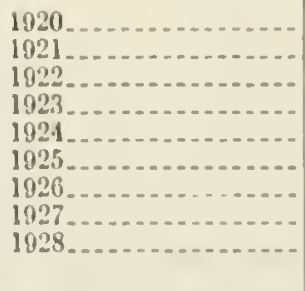 & $\begin{array}{l}30.0 \\
17.0 \\
20.0 \\
32.0 \\
24.0 \\
22.0 \\
140 \\
21.0 \\
19.5\end{array}$ \\
\hline
\end{tabular}




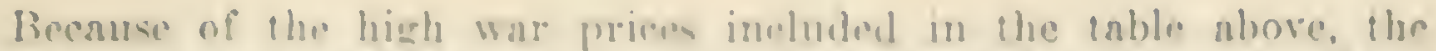

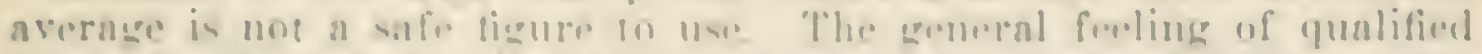

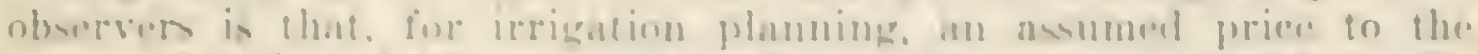

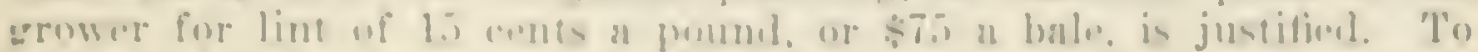

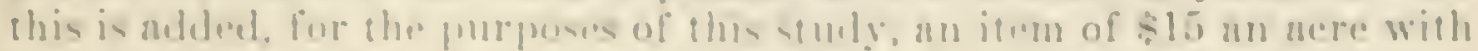

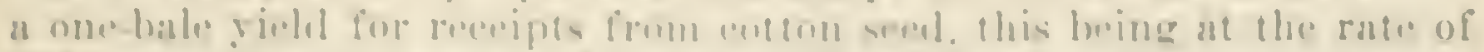

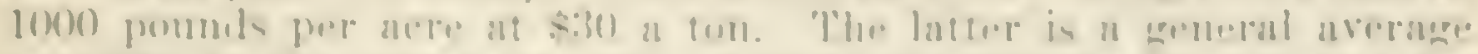
reported by the growers sisidel. Adeline the returns fur lint and for

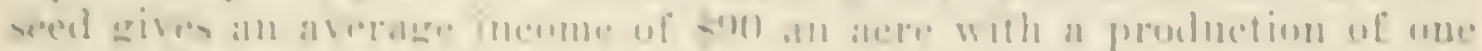
bale to the acte.

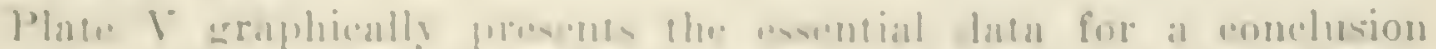

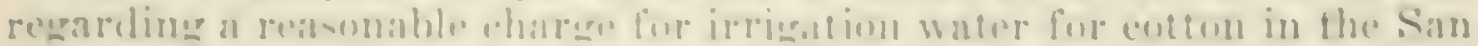

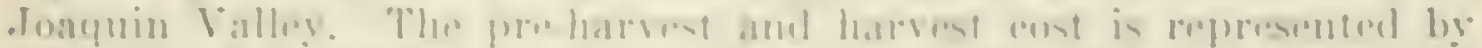

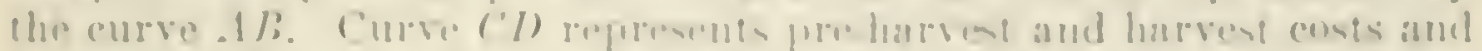

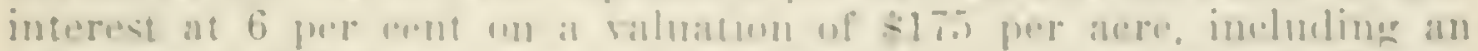

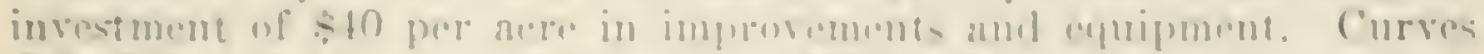

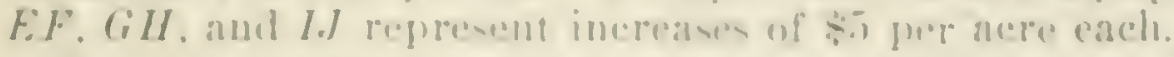

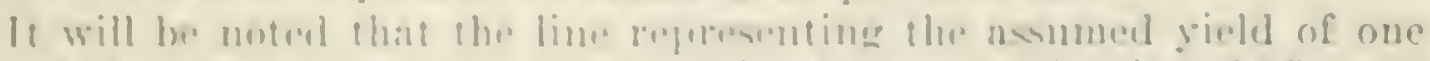

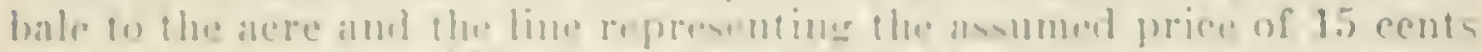

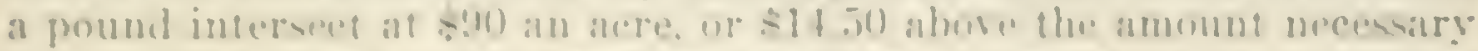

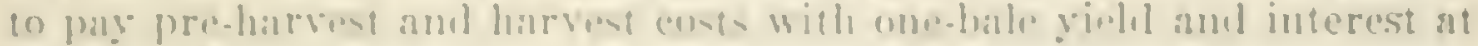
bi per ernt.

The record or alimale of irrigation water costs for the enterprises eom-illered in the prewent stuly (sme 'liable :3:3) show a range of from

NI.ATE: V

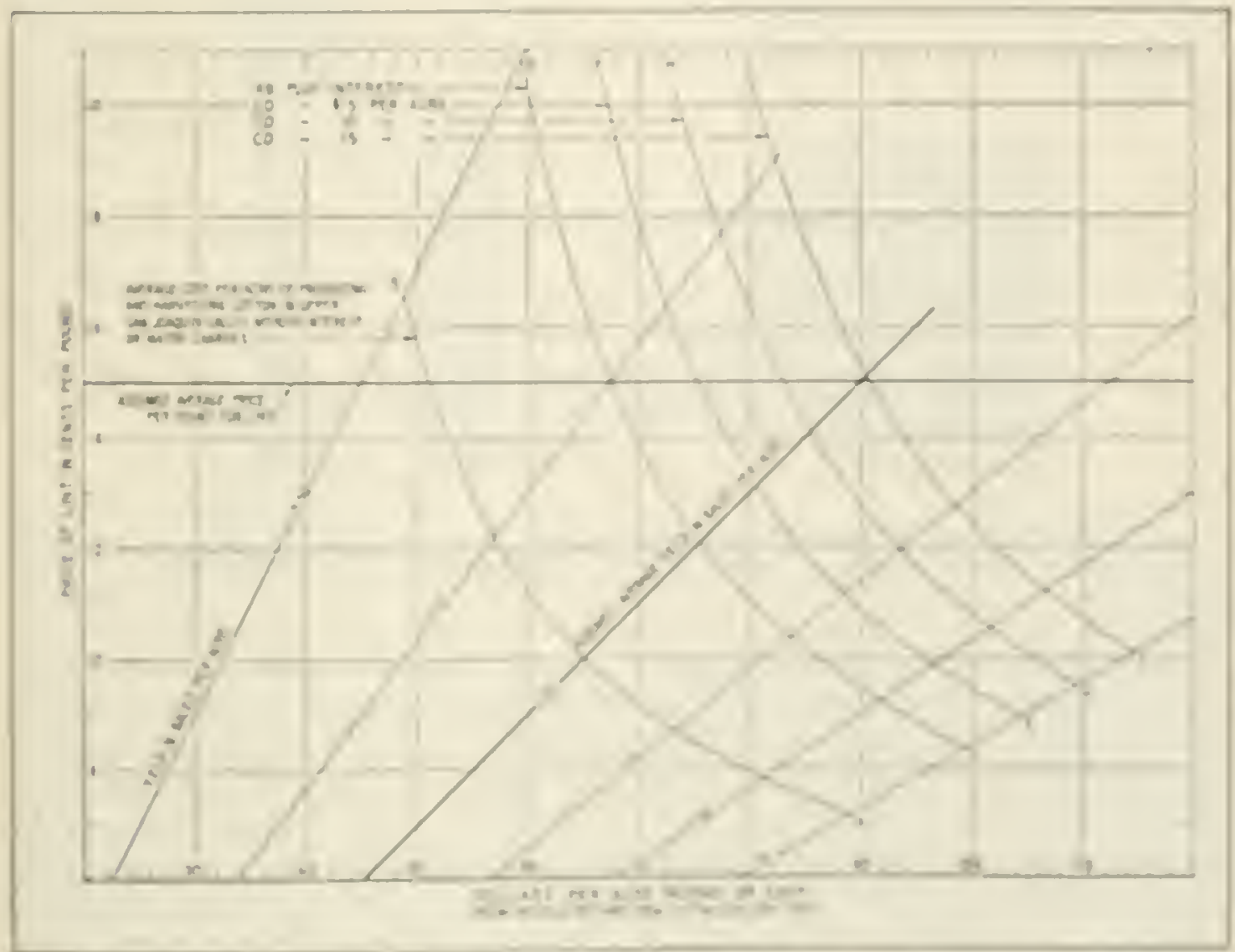

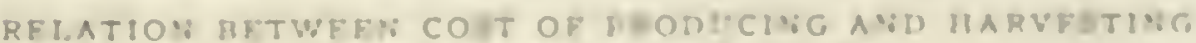
COTTO: ANU PAP U? BCOUE 
94 cents to $\$ 25.17$ an acre, with a ustual cost of $\$ 10$ to $\$ 12$. Costs where eotton is grown. as given in Chapter VIII, are of the same general order, being high under pumping systems in Kern County and the Tulare Lake areas and low under gravity systems.

\section{Miscellaneous Crops.}

The term "miscellaneous erops" usually ineludes such annuals as corn. sorghum, grain, and beans, and, where not grown as specialty crops, would also include regetables and other truck erops. Ordinarily their mater requirements-one or two irrigations per season-are about the same and, when not grown as speeialty erops, none of them stands apart from the others as to permissible irrigation charges. A moderate charge for irrigation water for such crops is always assumed. No special inquiry was made in commeetion with the present study regarding costs of produeing these erops, the thought being that present eharges for irrigation furnish an adequate guide for them.

Table 36 presents present irrigation water costs under a number of typieal San Joaquin Valley irrigation systems which include in their irrigated crops substantial pereentages of general crops.

TABLE 36

COST OF WATER AT DELIVERY POINT UNDER SOME TYPICAL SAN JOAQUIN VALLEY IRRIGATION SYSTEMS SERVING SUBSTANTIAL PERCENTAGES OF MISCELLANEOUS CROPS

\begin{tabular}{|c|c|c|}
\hline System & Iear & $\begin{array}{l}\text { Approximate } \\
\text { annual cost } \\
\text { of water to } \\
\text { irrigators, } \\
\text { per acre }\end{array}$ \\
\hline 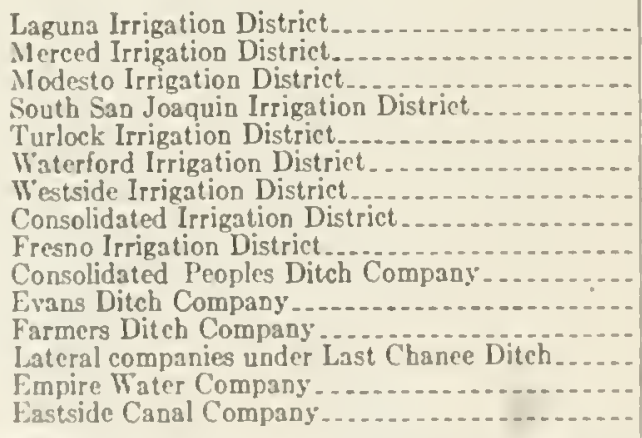 & $\begin{array}{l}1927-28 \\
1927-28 \\
1927-25 \\
1927-25 \\
1927-28 \\
1927-28 \\
1927-28 \\
1927-28 \\
1927-25 \\
1923-29 \\
1923-29 \\
1923-29 \\
1923-29 \\
1923-29 \\
1926-29\end{array}$ & $\begin{array}{ll}1 \$ 1 & 85 \\
19 & 00 \\
15 & 00 \\
16 & 45 \\
4 & 50 \\
16 & 35 \\
19 & 50 \\
12 & 20 \\
12 & 50 \\
=1 & 76 \\
\because 2 & 94 \\
11 & 05 \\
25 & 101.47 \\
21 & 00 \\
=0 & 50\end{array}$ \\
\hline
\end{tabular}

Sere Bulletin 21, Division of Enginecring and Irrigation, State Department of Public Works. In some cases there is an additional cost for operating private pumping plants and for maintenance of second iry latcrals.

From Chapter VIII, Tables 42,49 and 53 . In some rases there is an additional cost for operating private pumping plants.

Costs given in the above table are, with three exeeptions, seen to be much ligher in the irrigation districts than moler the mutual and public utily companies represented by the last six listed. The sysfoms which hare all-season of nearly all-season water are perhaps hest

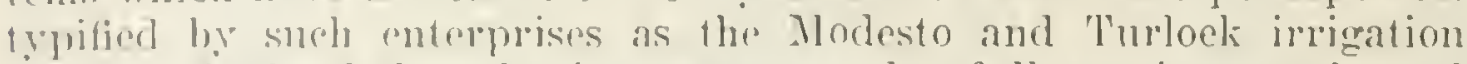
districts, both of these having storage and a full gravity supply and both having ancomplisher the development of most of their irrigable acreages. It is the concelusion of this repont that s.5 an ace is a

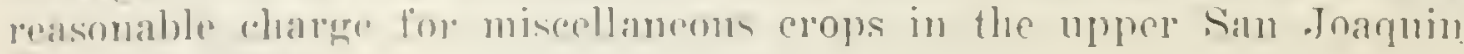
valley ronnties. 


\section{COST OF WATER TO IRRIGATORS IN THE UPPER SAN JOAQUIN VALLEY *}

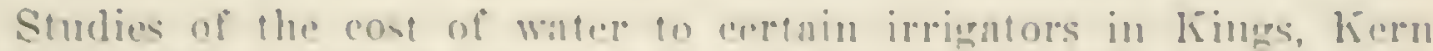

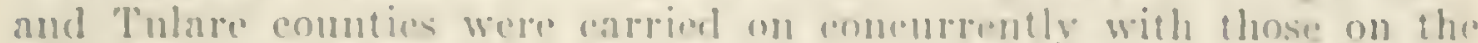

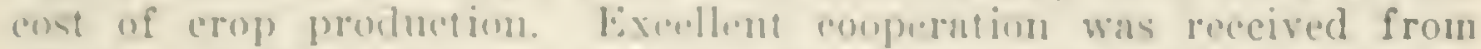
otticials of the irrigation diviriets. Watcre lompandes, the two power rompanise and lhe many individuals called upon for information.

Fammintion of the tahles whinh follow will disoluse that it was

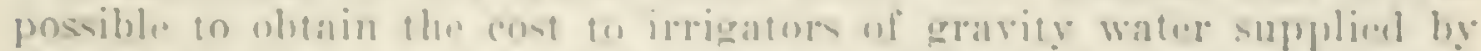
most of the impurtant aratrify ustems, hut that the mumber of farms served he imlividual pumpong plants upon which it was possible to obtain reliable data wilhin the time nvalable is a very small part of the tutal mumber. Within Kings, Kers, and loulare counties approximatoly 11,000 plectrically operated pumping plants, nut to montion a

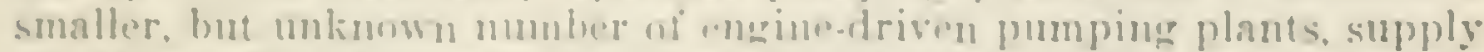
irigation water. hoth within and wihont areas receiving gravity water.

The cost of water in the irrigators reweiving water from an irrigale

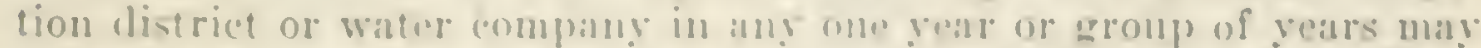

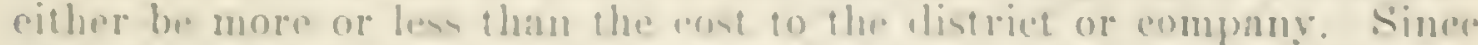

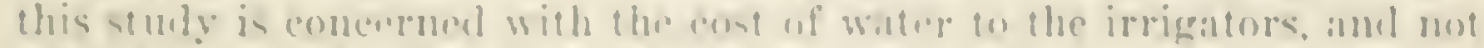
with the cost to the districets or complutime it is not necesary io

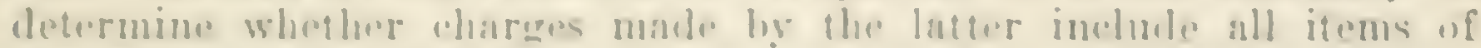
enst. such as deprecintion.

\section{Method of Determining Cost of Water Supplied by Farm Pumping Plants.}

"low following olemsents were considered as making np the rost of water to irrigaters uning farm fommping plants:

1. Jower sharge for l!n! irrigation seshon.

$\therefore$ Reprins an!l lubringtion.

3. Dopreciation.

4. Interment.

i. Tnxpe.

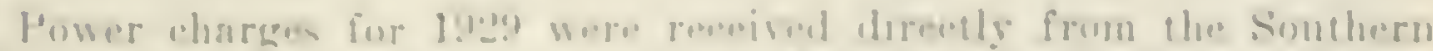

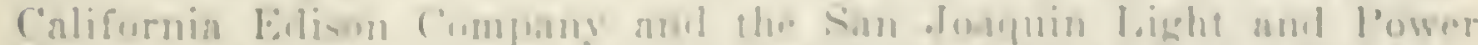

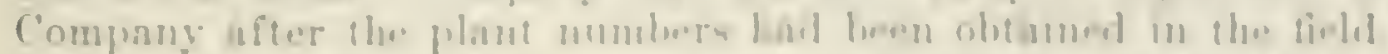

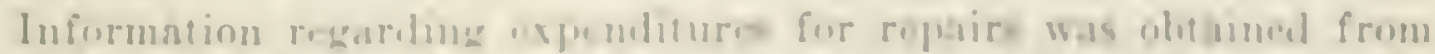

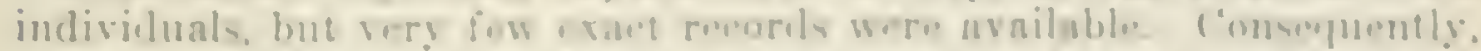

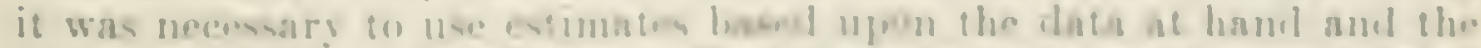

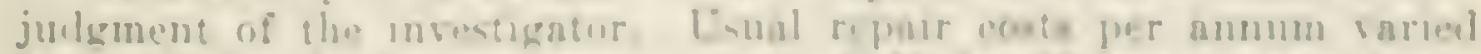

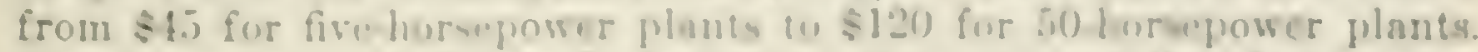
Repair enets in the "Tulare latke bastu. Where the quality of the water

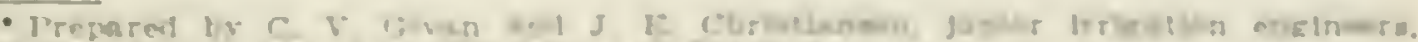
Dlvinlon of Irrlgatlon Inง 
eauses excessive corrosion, were from two to three times greater than the usual amounts.

Depreciation was aecomnted for by setting aside anmully an amount, whieh. when aecumulated with interest compounded annually at 4 per cent, would cqual the first eost of the wells and pumps at the end of their estimated periods of usefulness. The useful life of a well usually was taken at twenty years. The life of deep wells in the 'Tulare Lake Basin was estimated at from eight to ten years and some shallow wells from which salty water is pumped were depreciated in fire years. The normal life of pumps and aceessories was talien at fiftecn years, excepting those in Thlare Lake where ten years was used.

It has been suggested that the normal life of deep-well turbines should be taken at twelve instead of fifteen years. Such a ehange would increase the annual allownce for depreciation on deep-well turbines from 4.99 to 6.66 per eent and would raise the estimated cost of water supplied by farm pumping plants about 5 per cent in most instances.

The following table gives the percentage of first eost which must be set aside ammually to acemmulate the first cost within the indicated time.

\begin{tabular}{c|c|c|c}
\hline $\begin{array}{c}\text { Useful life in } \\
\text { years }\end{array}$ & $\begin{array}{c}\text { Percentage of } \\
\text { first cost }\end{array}$ & $\begin{array}{c}\text { Tseful life in } \\
\text { years }\end{array}$ & $\begin{array}{c}\text { Percentage of } \\
\text { first cost }\end{array}$ \\
\cline { 2 - 4 } & 18.46 & 15 & 4.99 \\
5 & 10.85 & 20 & 3.36 \\
8 & 8.33 & 25 & 2.40 \\
10 & 6.66 & & \\
\hline
\end{tabular}

Interest was taken at 6 per cent of first cost and taxes at 1 per cent, excepting in Kern County where an annual charge of 75 cents per horsepower of eonnected load was made. 'The assessor of Kel'n County places a valuation of $\$ 25$ per horsepower on all irrigation pumping plants, including wells.

\section{Cost of Water to Irrigators in the Foothill Citrus Belt.}

'The foothill eitrus belt of the upper. San .Joaguin Valley, extending from Kings River to Edison, a few miles east of Bakersficld, is supplied :! most entirely with irrigation watel pmuped from wells. Only small areas are within leach of gravity water. Beeause of the restrieted lature of local ground water supplies, pumping litts are ligh, generally ranging fom 100 to 250 feet, and the capacity of a pumping plant seldom exceeds 450 gallons per minute, the greater number delivering loss 1han 200 pallons per minule. From 50 to 75 per eent of the pumps nserl are deep-irell plumares.s.

The information obtained resaluling the eost of water to irrigators within this region is smmmarized in 'lables 39. 40, and 41.

Table 39 sols forth water costs within three irrigation distriets which relivered water to 14.533 acres in 1929. 'The usual eost of water to the irligatol was taken as the sum of the assessments and water tolls charged for the 192!) susnon. In each distriet the eost of water to certain individuals ras deteminel. It is important to note the wide variation between the usual eharge made by the irrigation distriet 


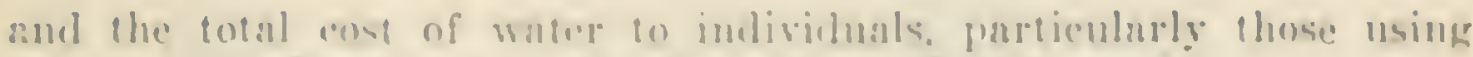

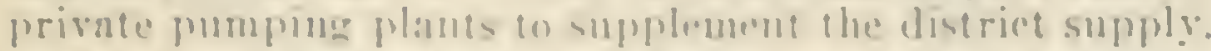

Costs of waller to irriantors served be wafore companies are slown in

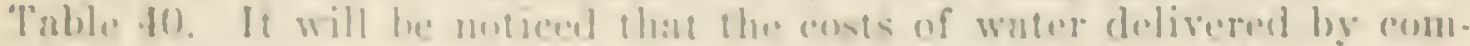

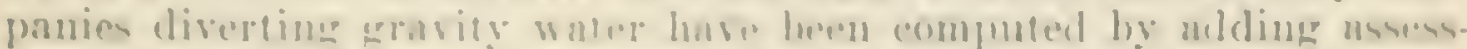

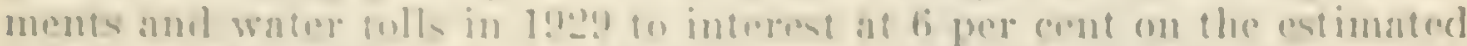

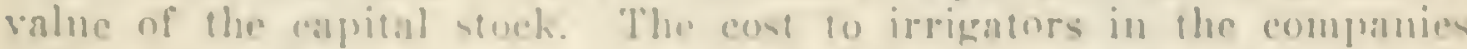
delivering watop pumped from wolls includes the assesements and tolle

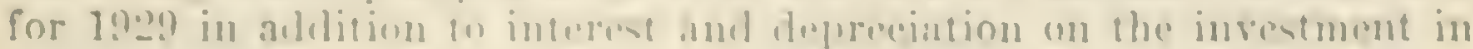
works.

Talue 41 includes the entimated costs of pumping with individual

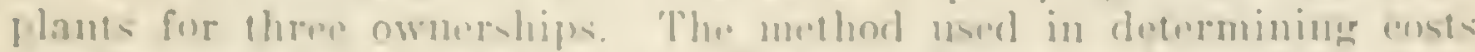

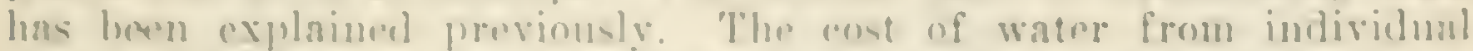
plants is subject on much greatre variation than indicatol hy table

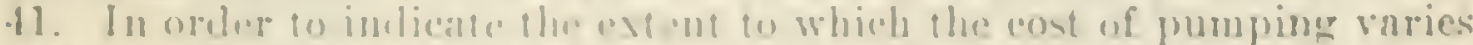

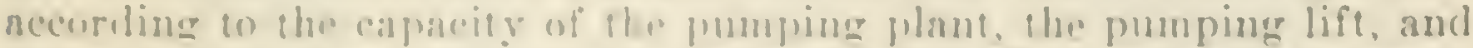

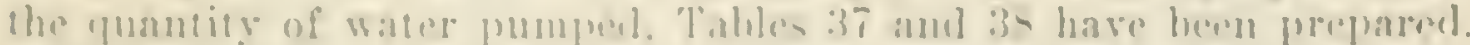

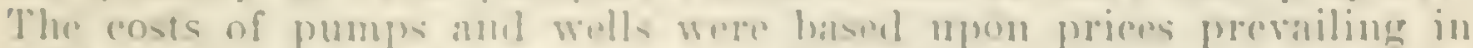

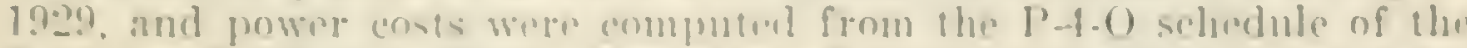

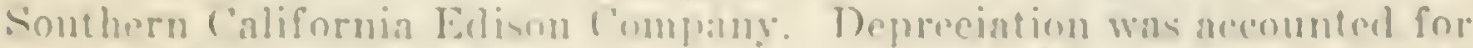

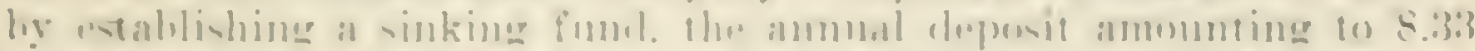

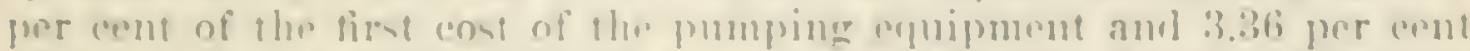

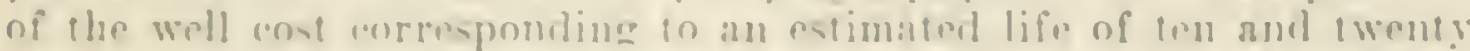

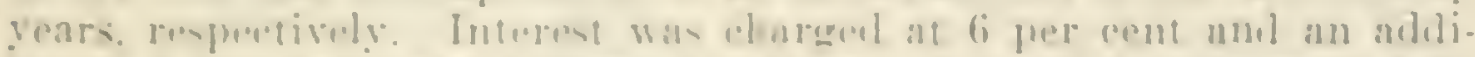
tional l per coule was allowed fore laxes. Ammal repairs were esti-

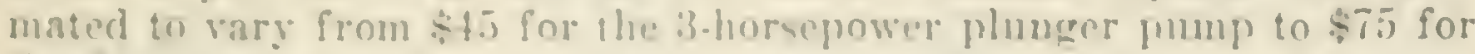
the :-5-horsepower deep woll inrbine.

\section{Cost of Water to Irrigators in Kern County Sorved by Public Utility Water Companies.}

A great deal of the area un kith Commly now smpplierl with gravity

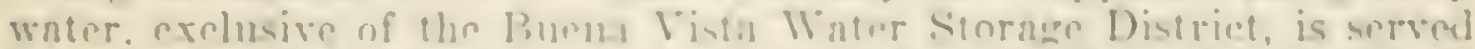
by public utility water companice com rolled hy the liern Comme ('sunt

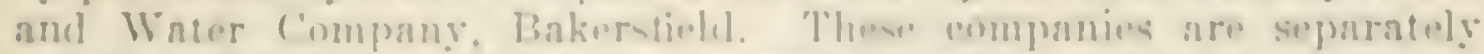

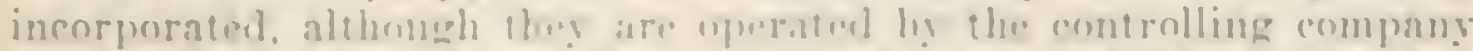
muler the direction of a chiof meineer nuel is superintendent. In addi-

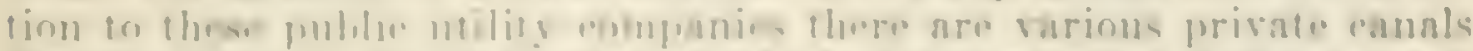
diverting wator. the insjority of which nre controlled nnd "pernien hy lhe kern Comme lamel l'ompans.

The water smpply not by llirs compandes is obtaimed from the natural tow of hern Tirer. the diremons fwing govermed in the first place ly the Mliller. Hagein ugreoue ate entered into by owners of lands in the vicinits of Buttonwllow se partios of the lirat part nud the various cannl companires nuel provale interests discring water in the vicinity of bakersfield as pertio of the weond part. the ngreenment

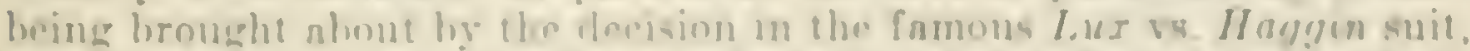
whel dofunitoly established the promeiples of riparian rights in finli-

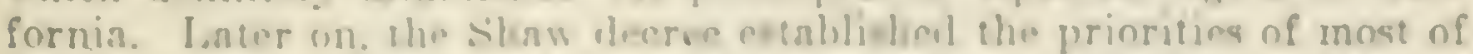
the disersinus of the pentirs of tbe aceond part to the Miller-Haggin

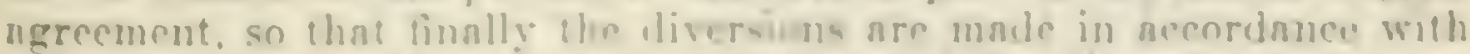
these two rloemments and slin, in the case of the divenions unt men. tioned in the Shaw denree. acenting to the dntes of the nppropriations. 


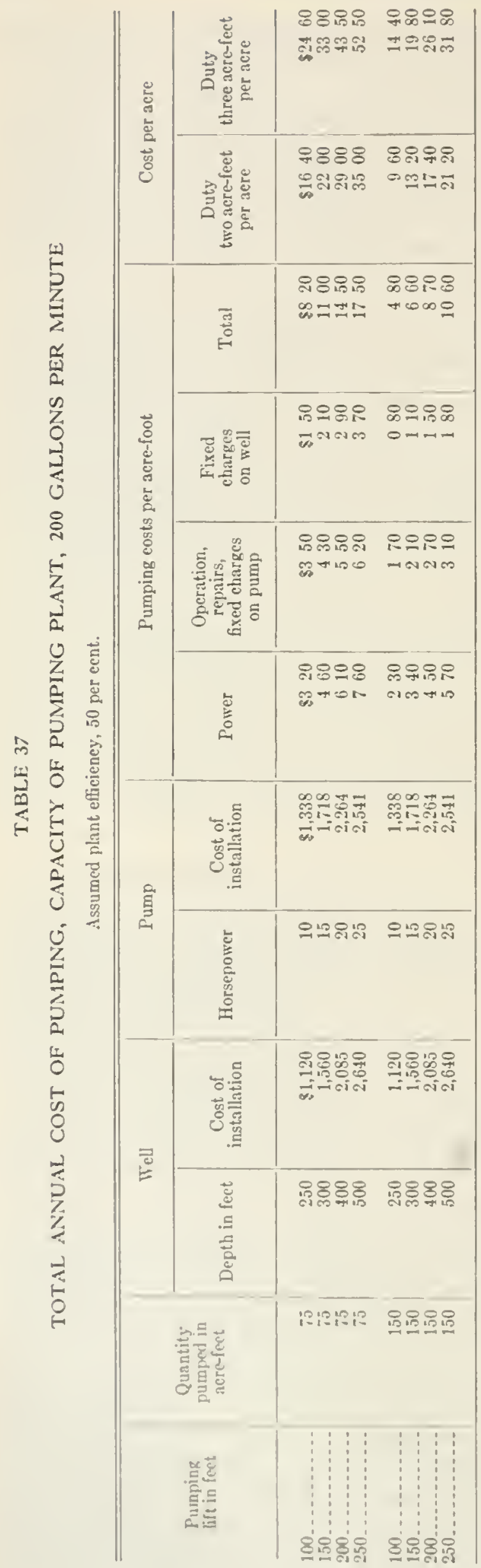

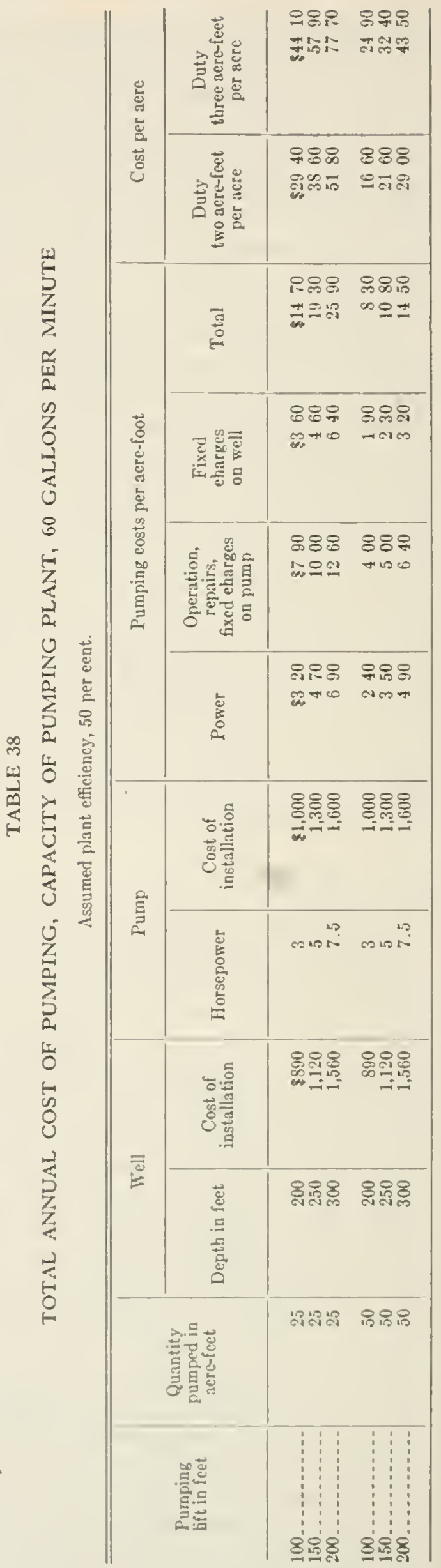




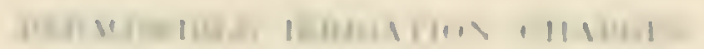

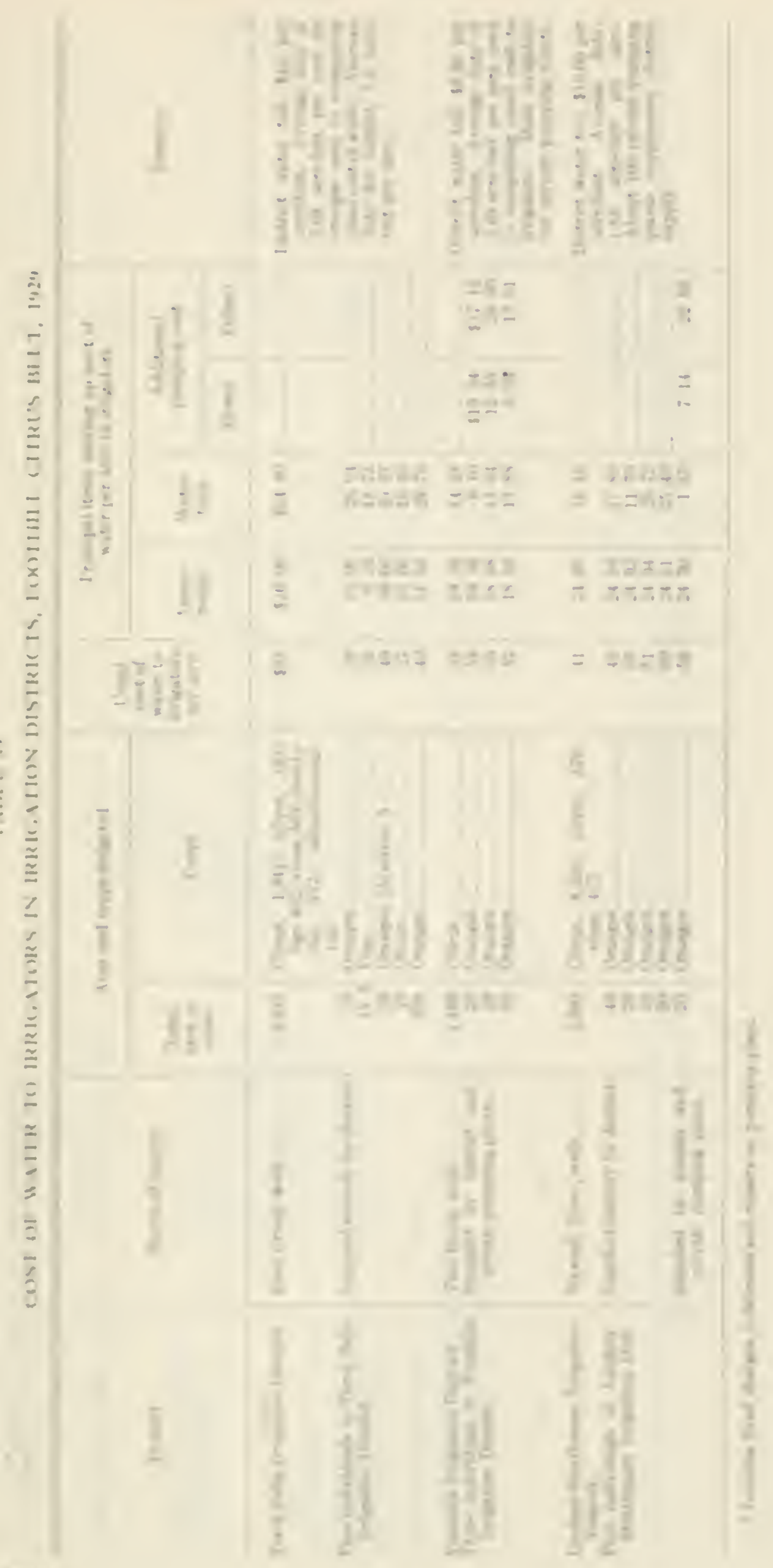




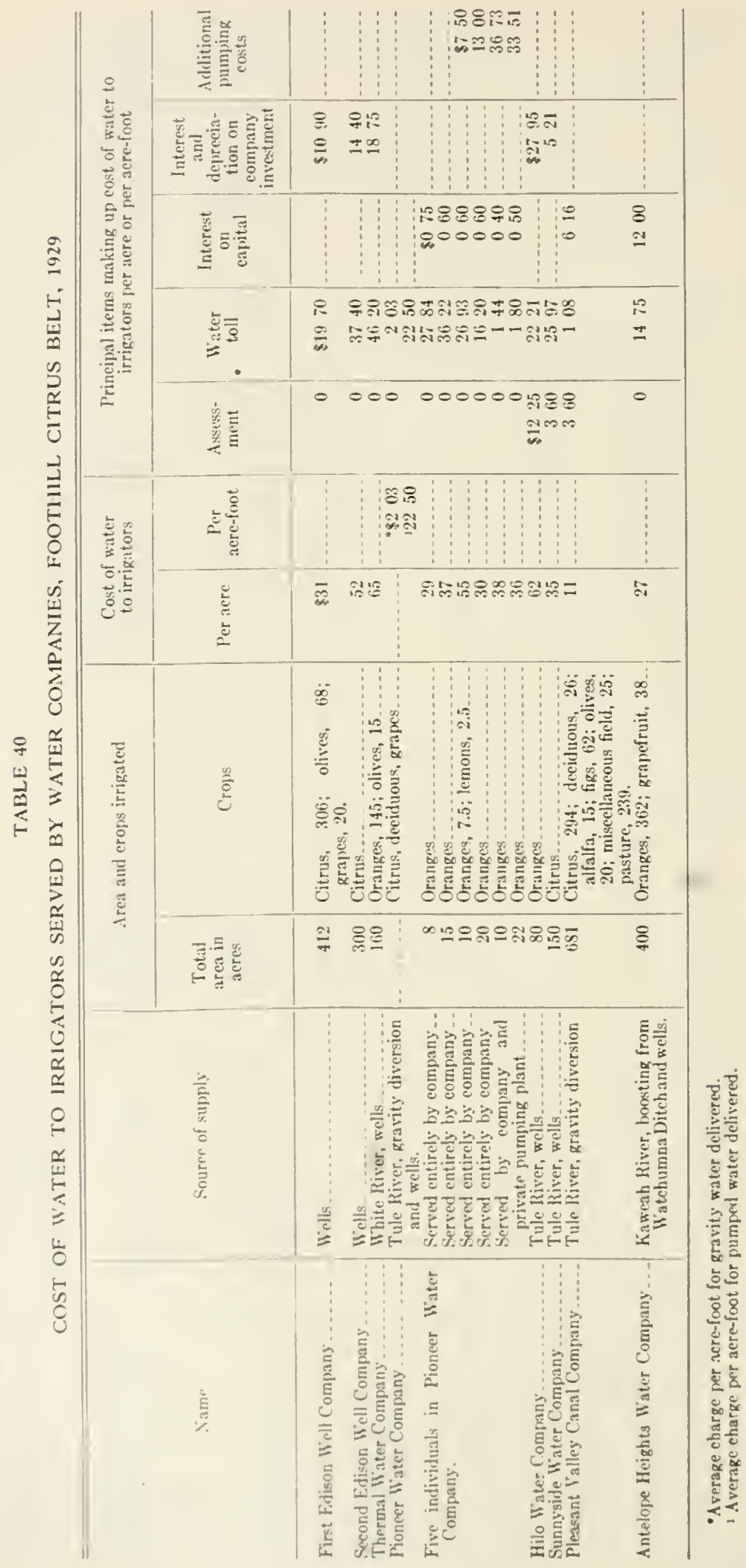




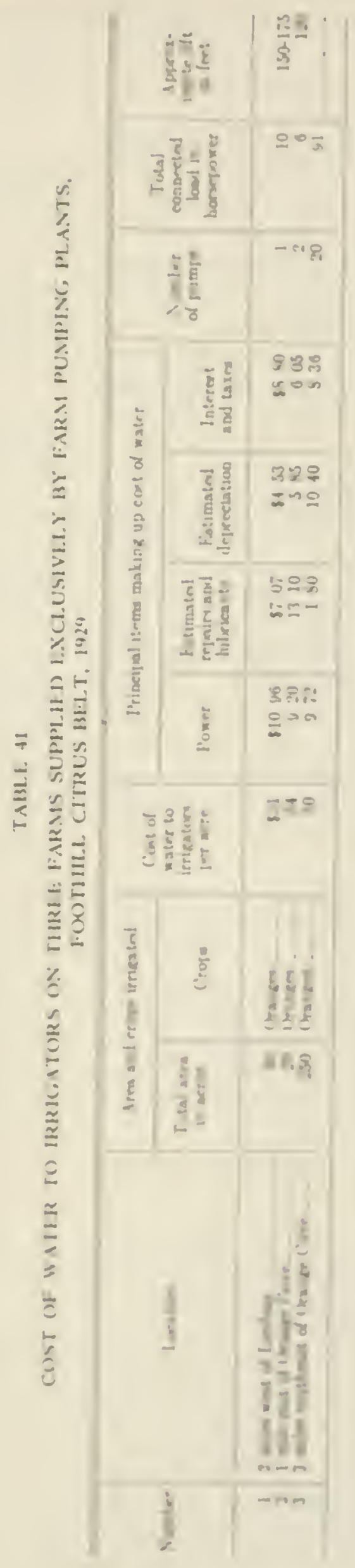


The earliest right is that of the Kern Island Canal, with an appropriafinn of :300 "ubie teet pere second as ol" Jamuary 1, 1870, while the dates of the original appropriations of the other canals lange from 1870 to 1876 .

Deliveries are mate by the ntility eompanies meler rules and regulations established by the Ralloart Commission of California in its Deeision No. 21973. "Under these rules, deliveries are made to definite mit areas in limited rotation periods and the maximum amomnt delivered per acre during any rotation period is definitely fixed. The canals and laterals to the lieads of llie consumers' ditches are maintained and operated by the canal companies. The reeords of deliveries are for the points where the water leaves the companies' canals and do not give the actual deliveries to the land.

A stummary of data relating to date of olwanization. principal erops giom, areas irrigated, average amount of water diverted, amounts of water delivered. charge for water, and average ammal costs per acre is given in Table 42. Attention is ealled to the fact that the average annual costs of water per aere as given are not necessarily the total arerage anmual costs to the area served, as smpplemental water is sunplied to some of these areas by private pumping plants. This is particularly true of the areas served by the Central, and East Side Canal companies and the Kern River Canal and Irrigation Company. There are no definite data arailable showing the extent of private pumping for a supplemental supply mder any of the canals.

The costs of water to the farmer's undel these eompanies bear no definite relationship to the costs of operating the canal systems sinee the present rates for water for at least the past 30 years lave remained the same. A petition is now before tle Railroad Commission for an inerease in rates.

Under publie utility water empanies, the right to water service has a value to the lands served. This right to serviee is somewhat similar to water rights represented by capital stock in mutnal water companies. No definite raluation is being placed mpon the right to serviee and no interest is being included on this value in the eost of water figmes given. For this reason, annual costs of water under public ntility. water eompanirs are hartly eomparable with ammul ensts under mutual water companies where interest on the value of eapital stoek is ineluded.

\section{Cost of Water to Irrigators in Kern County Served Exclusively by Farm Pumping Plants.}

Table 44 grives the eost of water to iprigrators on serentecu farms

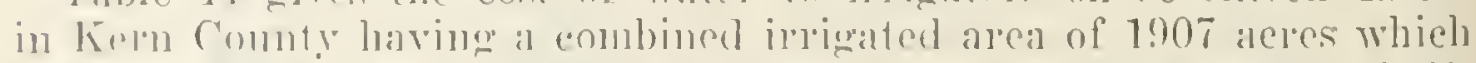

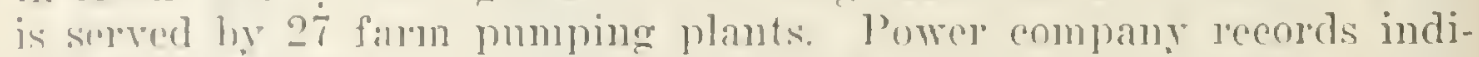

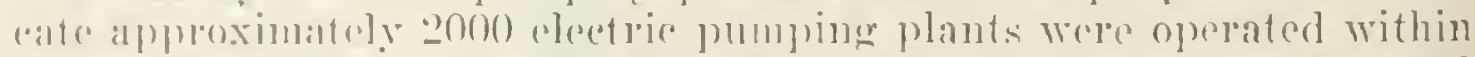

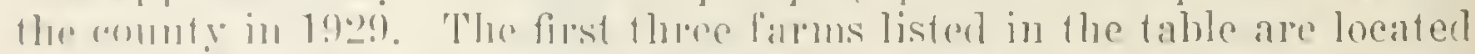

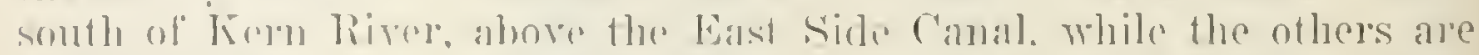

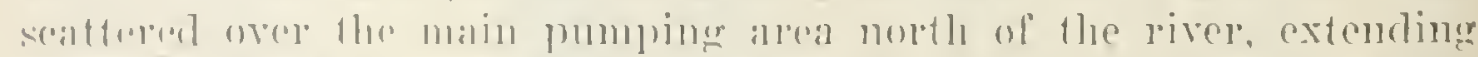

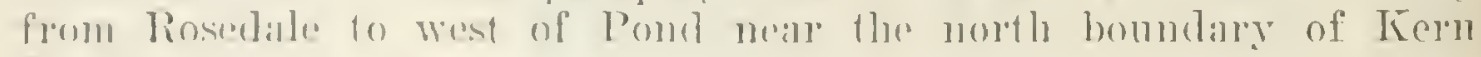
Commly.

'The reecht rapiel increase in pumping sonth of Keru River, in tlus Pupma Vista Lalie, and neal Butlomwillow. is ol particular interest. Before the introchetion of gravel-envelope wells in these areas, irriga- 


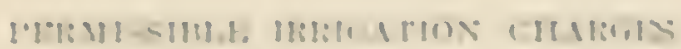

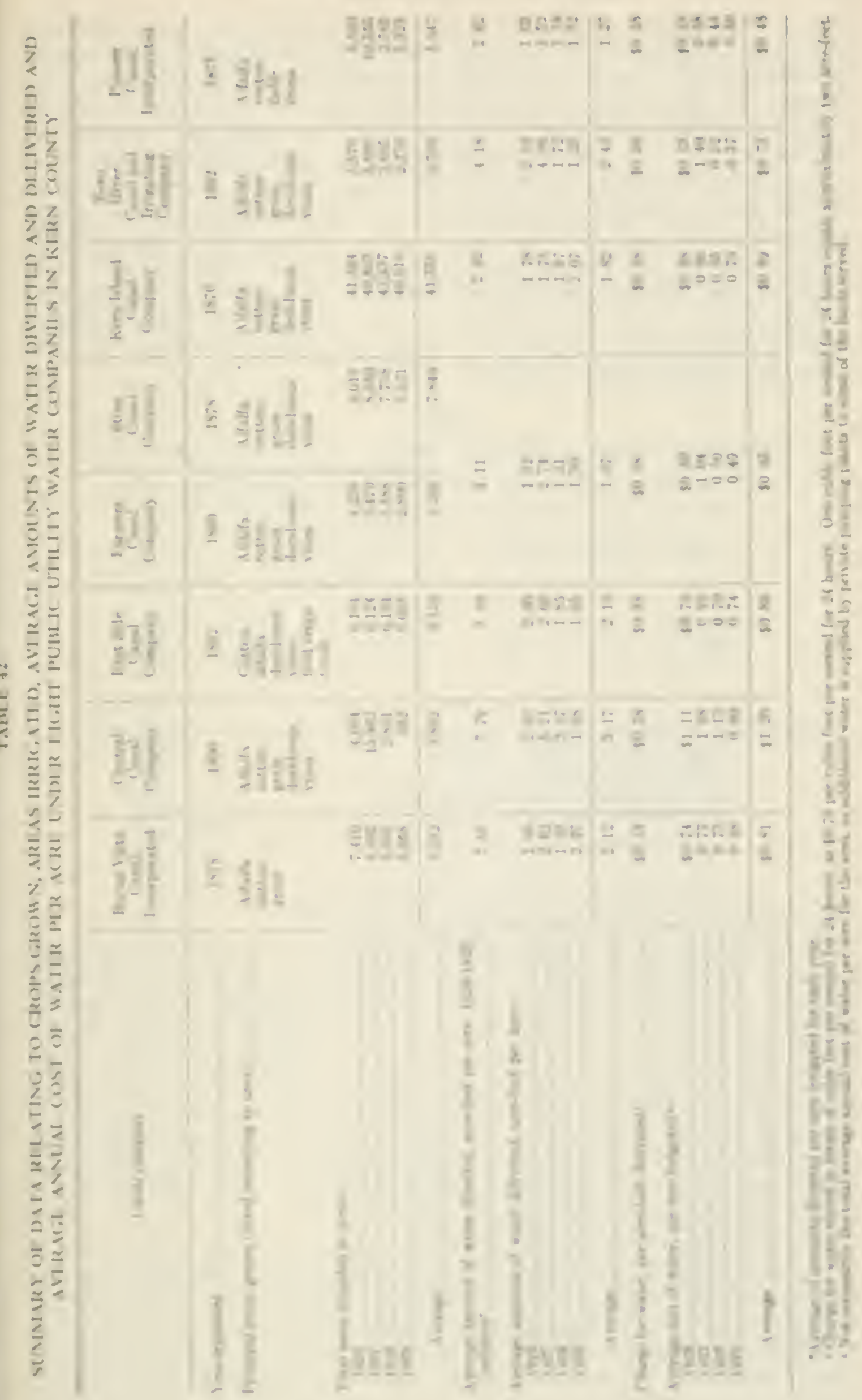


tion pumping was restrieted becanse yields obtained from ordinary stove-pipe wells, which penetrated the fine sands eomposing the waterbearing material, were not suffieient to make pumping attractive, even though the water table was near the surface. In drilling the gravelenvelope wells, an 18-inch, elean-cut, perforater easing is landed at depths of from 75 to 150 feet. From 25 to as much as 100 tons of gravel is required to form the envelope on the ontside of the easing. The prevailing price of drilling is $\$ 3$ per foot. Casing costs about $\$ 5.15$ a foot and rock is delivered for $\$ 2.35$ a ton. The rields of these wells usually range from 1200 to 2000 gallons per minute with pumping lifts of from 30 to 50 feet. The tabulation in Table 43 gives an estimate of the eost of pumping from a gravel-envelope well 125 feet in depth using a 30-horsepower deep well turbine, capacity 1600 gallons per mimute, when the pumping lift is 40 feet.

TABLE 43

ESTIMATE OF COST OF PUMPING FROM A GRAVEL ENVELOPE WELL

Deep-well turbine pump; assumed plant efficieney, 55 per cent; pumping lift 40 feet.

\begin{tabular}{|c|c|c|c|}
\hline \multirow{2}{*}{ Acre feet pumped per annum } & \multicolumn{3}{|c|}{ Cost of pumping per acre foot } \\
\hline & Power & Other charges & Total \\
\hline $\begin{array}{l}400 \\
600\end{array}$ & $\begin{array}{rl}81 & 31 \\
1 & 07 \\
0 & 91\end{array}$ & $\begin{array}{rr}31 & 15 \\
0 & 77 \\
0 & 51\end{array}$ & $\begin{array}{rr}82 & 46 \\
1 & 84 \\
1 & 42\end{array}$ \\
\hline
\end{tabular}

Annual fixed charges and repairs, included in "other charges" in the above table, are estimated as follows:

Depreciation on well, \$1,200 at 5 per cent_......... $\$ 60$

Depreciation on pump, $\$ 1,600$ at 5 per cent $\ldots \ldots \ldots$

Interest on investment, $\$ 2,800$ at 6 per cent.........

Taxes, 30 horse power, at $\$ 0.75$ per horse power $\ldots \ldots \ldots \ldots$

Annual repairs on well and pımp.

Total annual charges, except power .............. \$460

\section{Cost of Gravity Water in the Hanford Area, Kings County.}

The northern part of Kings County, in the vieinity of Hanford and Lemoore, is served by three large canals and several independent laterals. 'The water supply is obtained from Kings River, these eanals being understood to have rights subsequent only to the Fresno Canal in date of priority. 'The Peoples Ditch, the upper of the three main canals, serves a gross area of approximately 60.000 acres in the northeastern portion of the comuty, chicfly to the north and east of Hanford. The Last Chance I iteh serves the coutral portion of about 33,000 aeres now embraced in the Imsermo lrpigation District, and the Lemoore Canal serves the Isemoner Treigaliom Distriet of ahout 52.000 aeres in the western portion of the area.

The diversions l'mom Kings liver are made aceording to Sehedule $A$ of the Kings River Waler Association. 'The schedule allotment for the Lemoore Camal hegins with 70 seronet-loed with ihe river stage at 200 second-feet. The Ponples Diteh allotment begrins with sis seeond-feet with the rivere stage at :30) second-fect and the Ianst Chance Diteh allotment begins with 46 second-feet with lhe river stage at 450 seeond-feet. 'The sehedule allotments increase to a maximmm of 450 second-feet for 


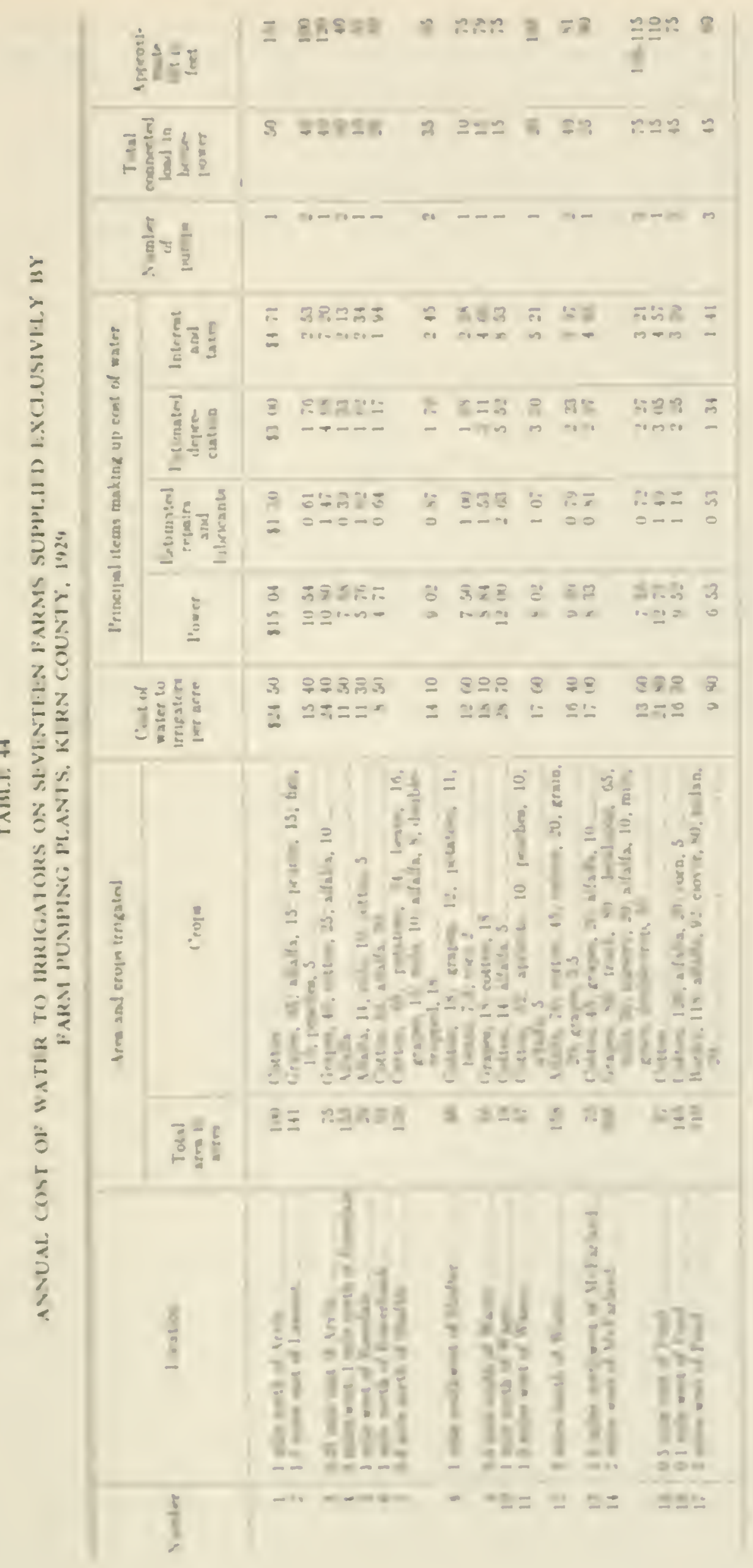


the Tomoole Canal, 550 second-fert for the Penples Diteh. and 325

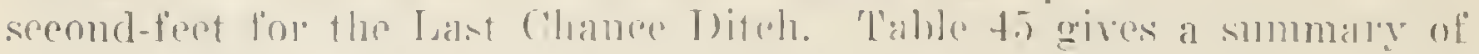

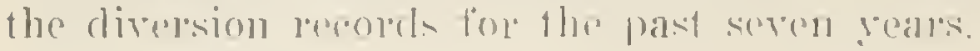

TABLE 45

SUNIMARY OF DIVERSION RECORDS, KINGS COUNTY CANALS

\begin{tabular}{|c|c|c|c|}
\hline Canal & Peoples & Last Chanee & Lemoore \\
\hline Average date of end of $\mathrm{run}^{2} \ldots \ldots$ & August 10 & July 19 & September 8 \\
\hline Average length of run, days ${ }^{2} \ldots$. & 294 & 189 & 303 \\
\hline $\begin{array}{l}\text { Annual diversion, nere-feet }- \\
1923 \ldots \\
1924 \ldots \\
1925.1926 \\
1927 \\
1928 \\
1929\end{array}$ & $\begin{array}{r}149,336 \\
83,167 \\
170,703 \\
129,011 \\
217,131 \\
119,067 \\
100,527\end{array}$ & $\begin{array}{l}63,829 \\
18,270 \\
63,738 \\
52,492 \\
17,125 \\
45,162 \\
36,456\end{array}$ & $\begin{array}{r}125,360 \\
48,419 \\
95,0.59 \\
81,671 \\
119,498 \\
70,305 \\
59,643\end{array}$ \\
\hline Averages. . . . . & 138,420 & 53.867 & 85,709 \\
\hline
\end{tabular}
Norks.

Kings River Water Master Reports, by Charles L. Kaupke; Nivision of Water Rights, State Department of I'uhlic

"Days when the averag" laily flow was less than five secon l-feet not eounted.

a The average annual rum-off of Kings liver for this periorl was $1,142,200$ acre feel, or 61.8 per cent of the mean an anal run-off for the 34 year period, $1896-1929$, inchivive. See table 46.

'The run-off of Kings River during the pelion from 1923 to 1929 has beon below normal every year exeept 1927, as shown in Table 46.

TABLE 46

IRUN-OFF OF KINGS RIVER AT PIEDRA'

\begin{tabular}{|c|c|c|}
\hline \multirow[b]{2}{*}{ Year } & \multicolumn{2}{|c|}{ liun-ofi } \\
\hline & $\begin{array}{l}\text { Aere } \\
\text { feet }\end{array}$ & $\begin{array}{l}\text { Per cent of } \\
\text { menn }\end{array}$ \\
\hline 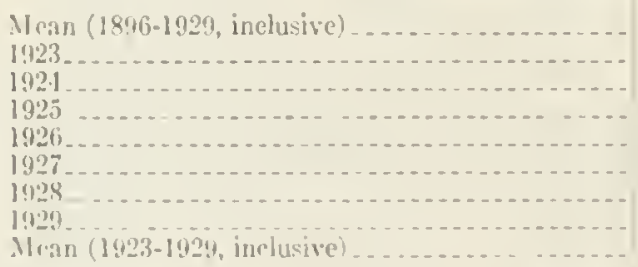 & $\begin{array}{r}1,763,200 \\
1,300,300 \\
3,39,170 \\
1,28,2,300 \\
1,0 ! 18,8: 00 \\
1,983,400 \\
891,370 \\
837,190 \\
1,142,2110\end{array}$ & $\begin{array}{rr}100 & 0 \\
8.5 & 1 \\
202 & 0 \\
72 & 2 \\
1 i 3 & 2 \\
112 & 5 \\
50 & 1 \\
47 & 5 \\
64 & 5\end{array}$ \\
\hline
\end{tabular}

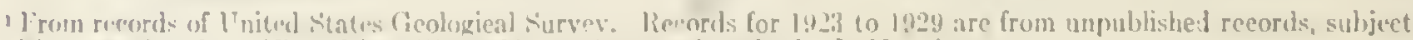

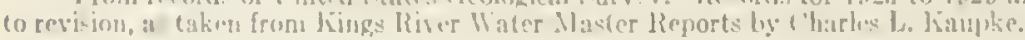

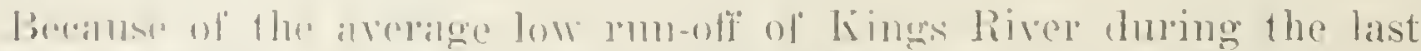

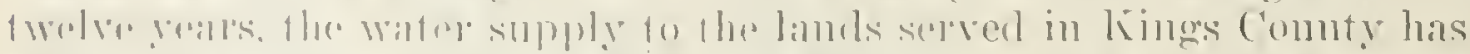

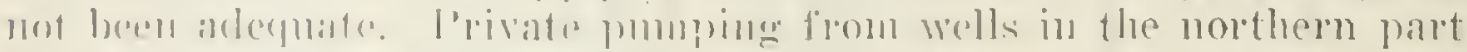

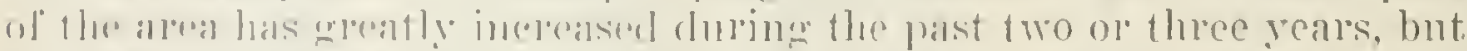

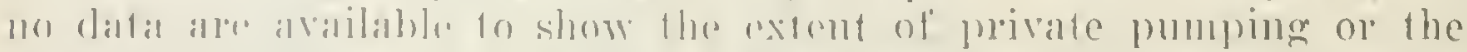

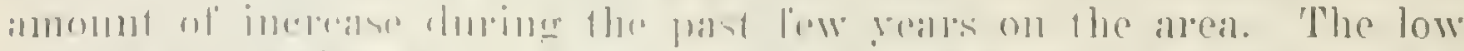

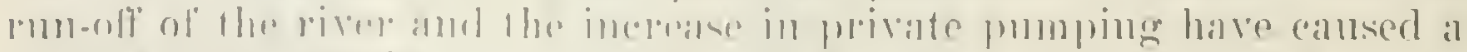

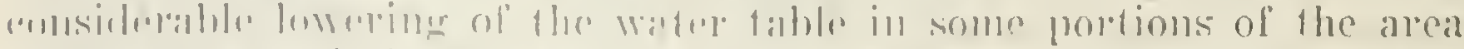

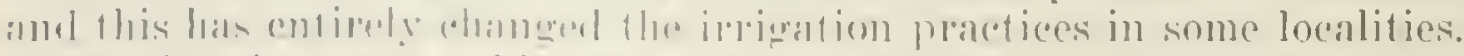

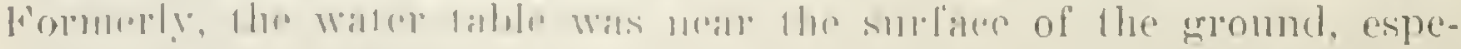

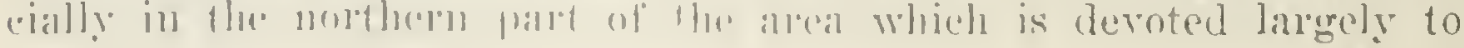




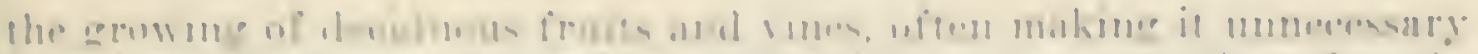

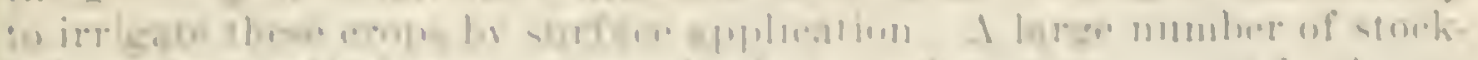

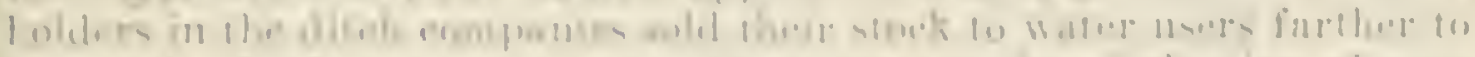

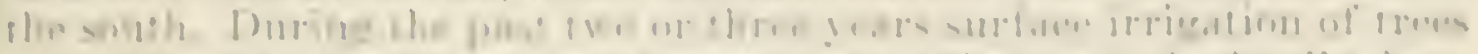

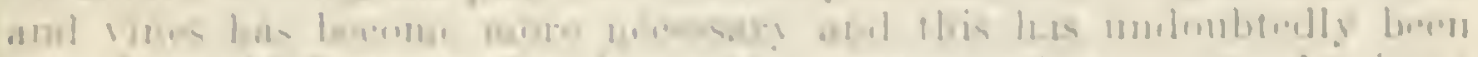

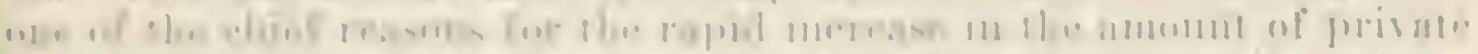

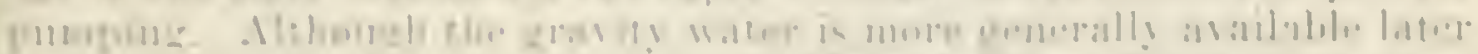

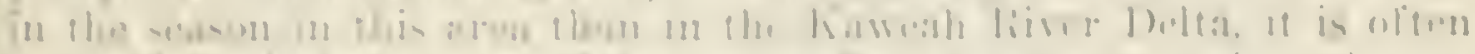

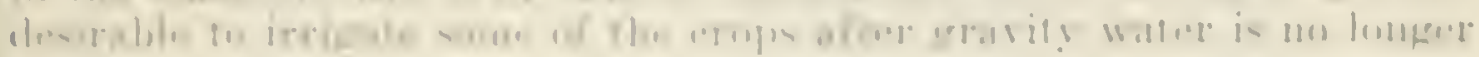
(1) lie iral.

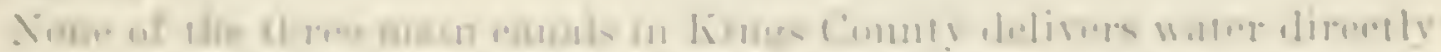

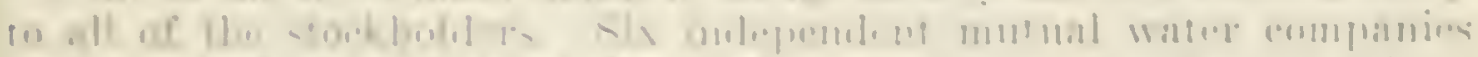

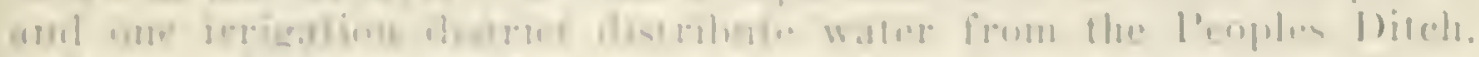

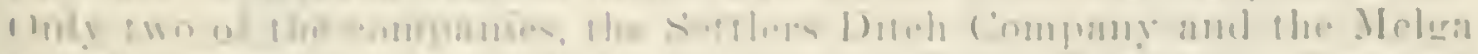

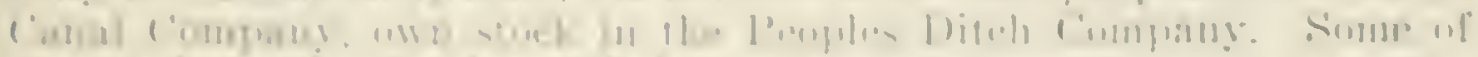

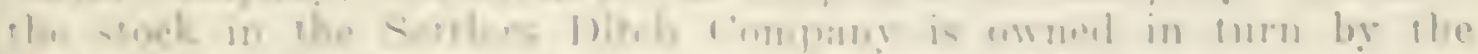

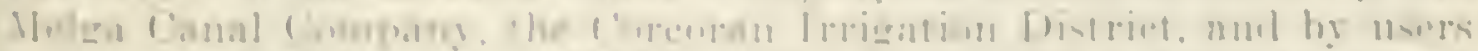

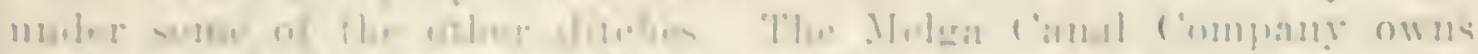

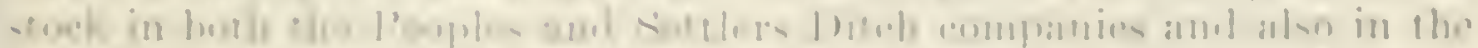

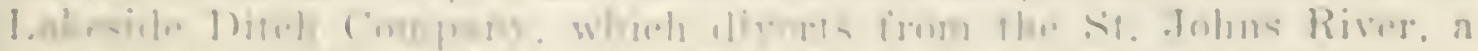

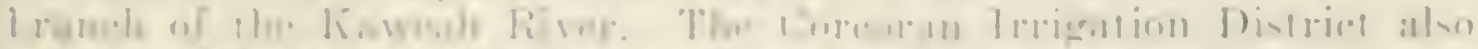

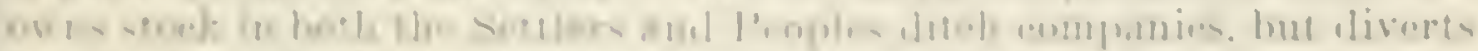

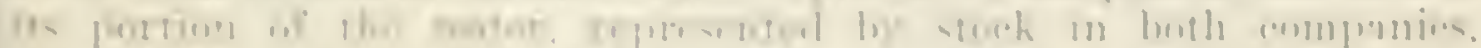

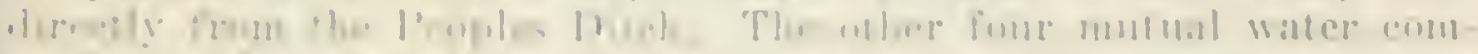

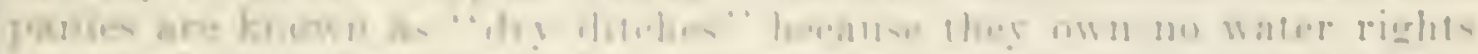

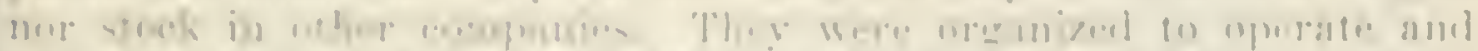

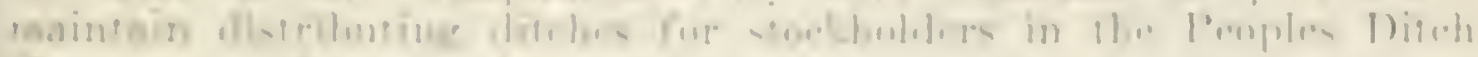

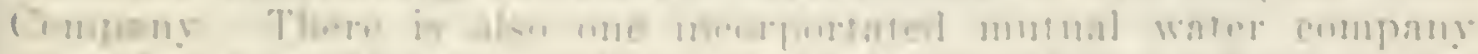

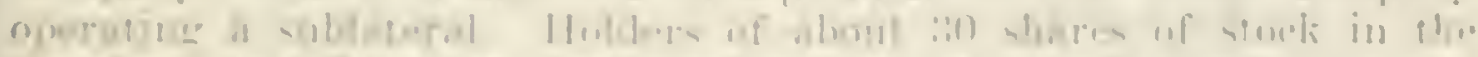

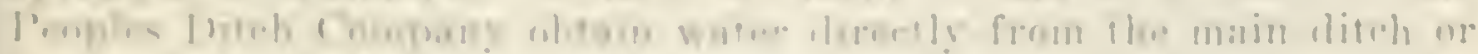

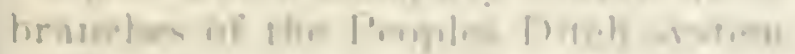

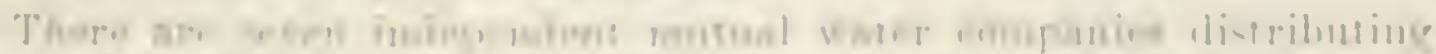

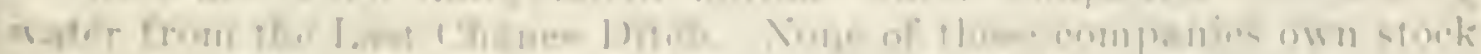

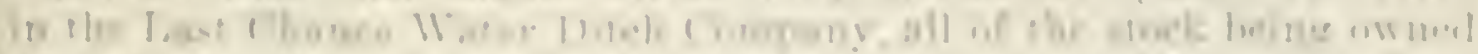

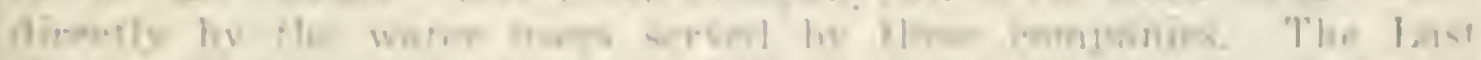

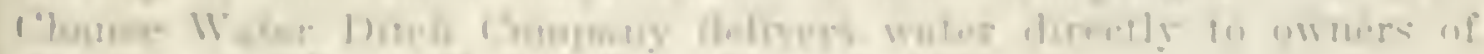

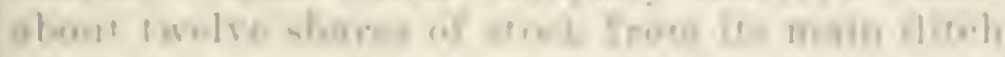

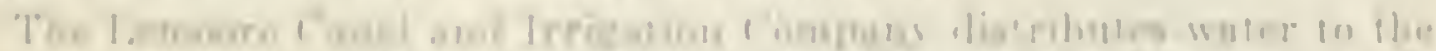

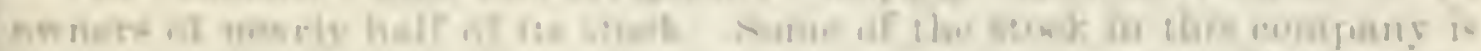

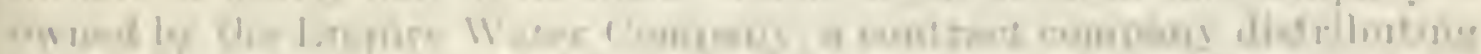

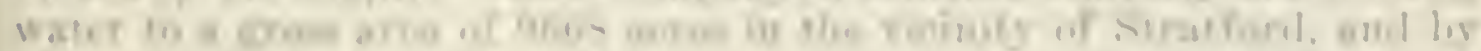

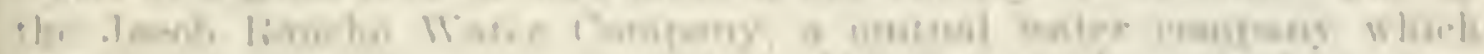

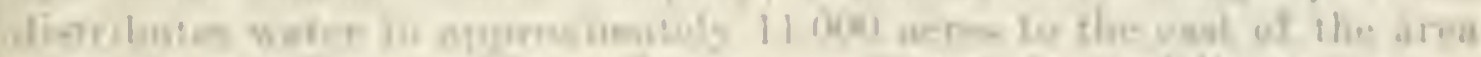

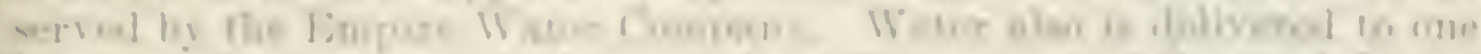

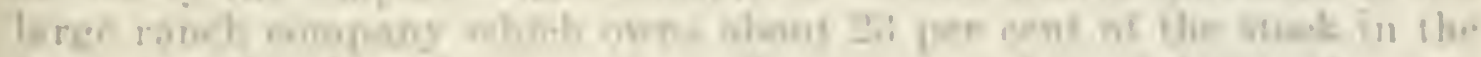

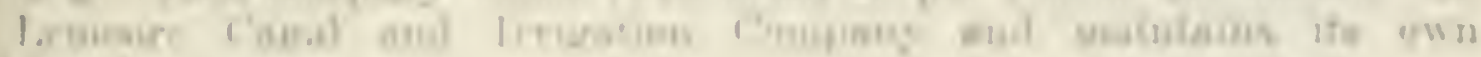

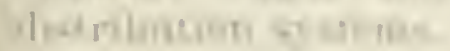

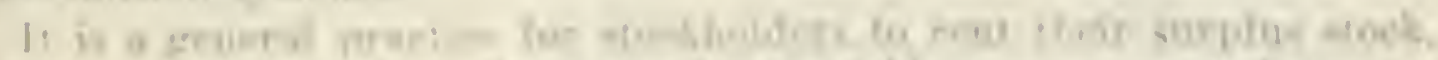

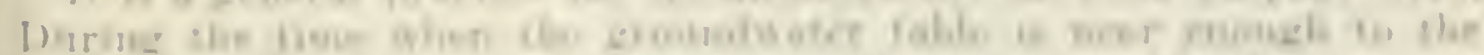

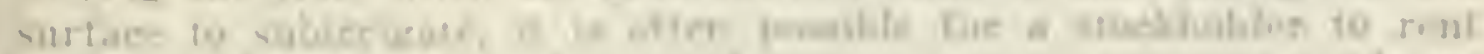

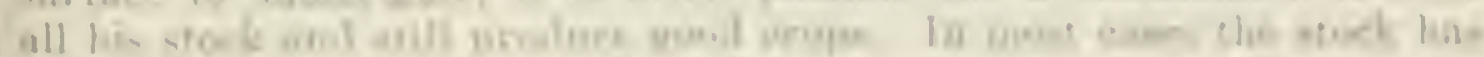

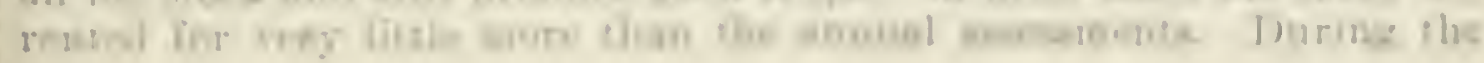


last few years the Coreoran Irrigation District has purchased and lented a number of shares in both the Peoples and Settlers diteh companies. This has resulted in a considerable increase in the value of stock in these companies and las had a marked influenee upon the value of stock in the Last Chance and Lemoore ditch eompanies.

In 1916 the area served by the Empire Water Company on the east side of Kings River was organized as the Stratford Irrigation Distriet for the purpose of taking over the distribution systems, but an agreement was never reached. The district has not been active. In 1920 the area served by the Lemoore Canal was organized as the Lemoore Irrigation Distriet and the Stratfold Irrigation Distriet was ineluded within this distriet, althongh it did not disorganize. The primary purpose of the organization of the Lemoore Irrigation Distriet was for participation in the proposed Pine Flat project. 'The gross area of the distriet is 52.300 aeres. The distriet has never taken over the irrigation system of the canal company.

The area served by the Last Chance Diteh Was organized as the Tucerne Trrigation Distriet in 1925 for the purpose of participation in the proposed Pine Flat project. The gross area in the distriet is 33,407 aeres. The distriet has not taken over Last Chance Diteh.

A summary of data relating to organization, value of stock, amnual assessments, and costs of water is given in Tlables 47,48 , and 49 .

\section{Cost of Water to Irrigators Using Farm Pumping Plants in Tulare Lake Basin.}

The prineipal supply of irrigation water in 'l'ulare Tuake Basin is obtained from deep wells, which in this area usually penetrate to depths of 1800 to 2200 feet. Formerly, artesian flow oceurred from some of these wells, but continued pumping has eansed the water table to recede until pumping lifts range from about 120 to 200 feet.

Deep well turbines are used exclusively for pumping. Thirty to o-horsepower units usually have eapacities of from 500 to 900 gallons per minute, while some larger tmbines driven with 100-horsepowel motors pump as mueh as 2000 gallons per minute. Water from the deep wells contains gas and sulphur compounds which eorrode both pumps and well casing to such an extent that the usual life is considered to be from eight to ten years. Repair charges are eorrespondingly high. $\$ 1,000$ per annum being considered a leasonable amomnt to cover repairs to a deep well and pumping plant in the lake bottom.

Within reeent vears water from shallow wells, usually ranging from 50 to 100 feet in deptl, has been used to supplement the supply from deep wells in the eastern portion of the basin south of Coreoran. The water from these wells is alkaline and is mixed befole being used for irrigation with water from the deep wells. North and east of Coreoran, water from the shallow wells is of bettop ruality. The enst of the shallow wells is msually less than $\$ 300$, and most of those located south of Coreoran corrode and eollapse within five years. Yields of from 150 to 300 galloms per minute are obtained with small deep well turbines driven by 5 and 7.5 -lolsepower motors.

The high eost of repairs and short life of the wells and pumps is offset in a gleat extent by the fact that the pumps are operated throughout the rear. which reduees the cost of water materially. For instance, the cost of power for irrigating 3353 acres of wheat and barley in the 


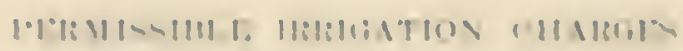

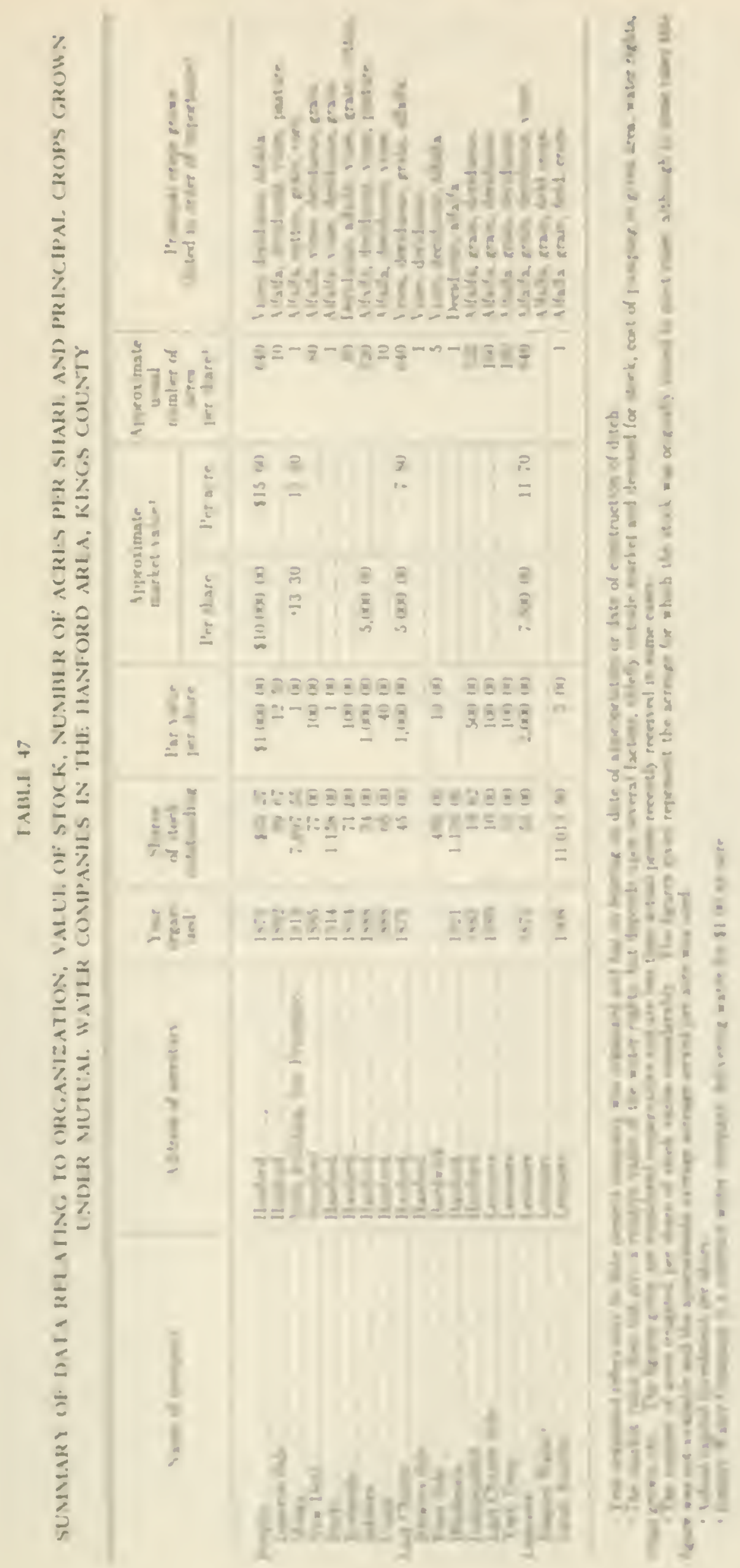




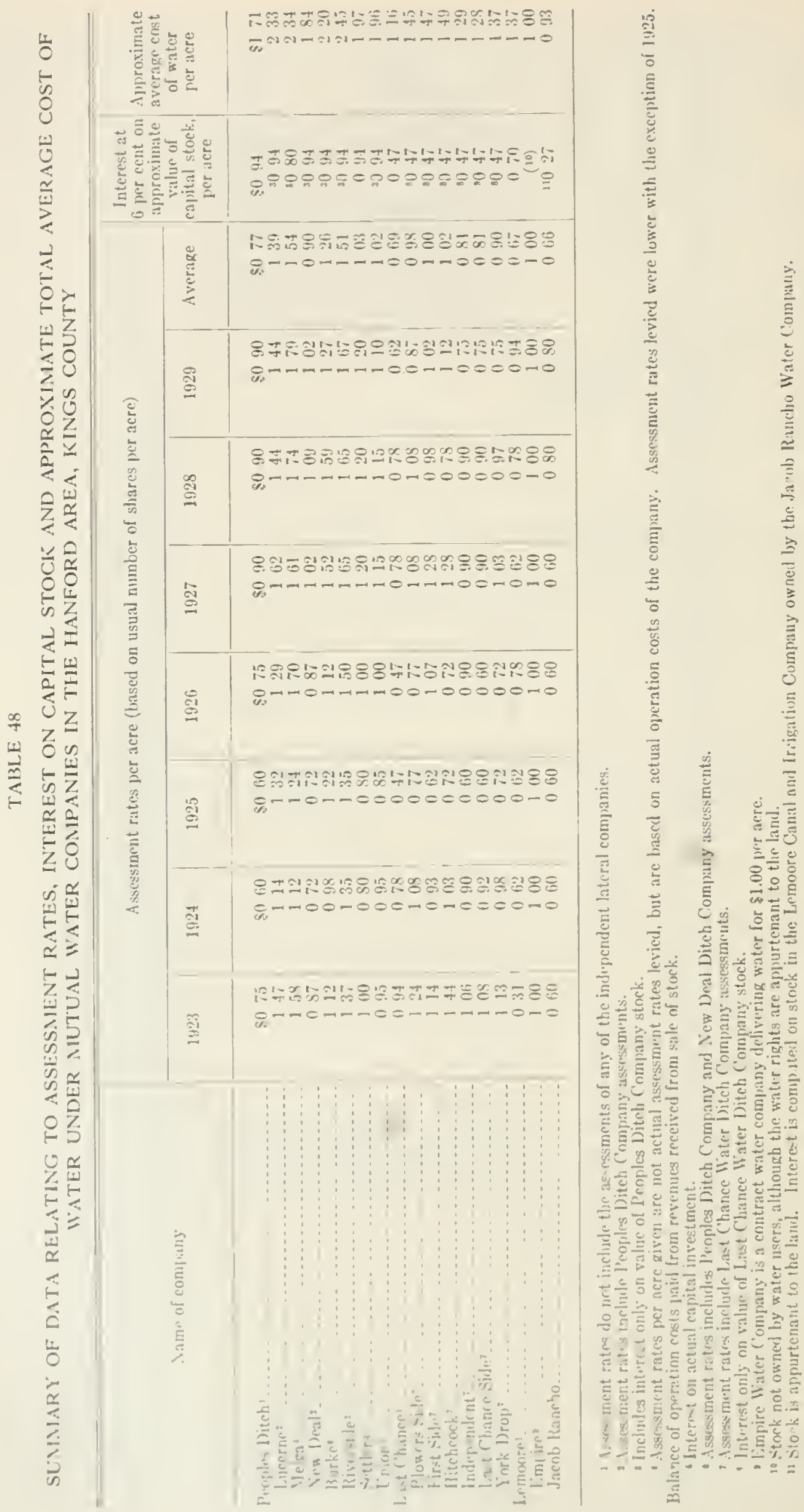




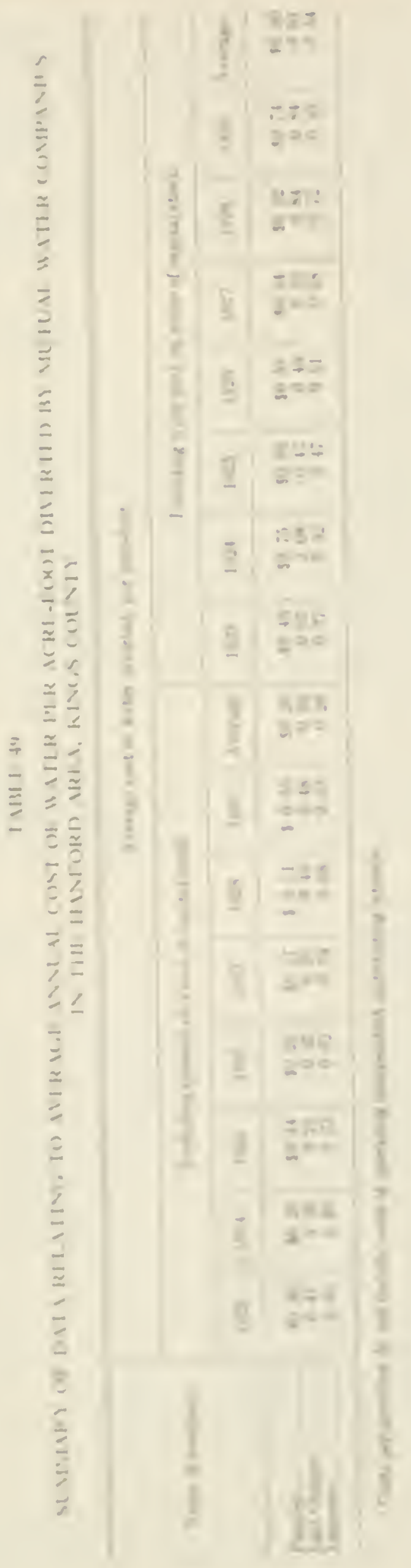


lake bottom anounted to $\$ 16,05: 3$, approximately $\$ 4.80$ per acre and fixed charges, inchding repairs, lorought the total estimated cost up to $\$ 4.10$ per alcre. The pumping lift was abont 170 feet.

All farms shown in Table 50 were located within the Corcoran Irrigation I District. The assessment on lands within the distriet for the 1929 season was $\$ 2.05$ an acre and the water supplied by the district was delivered for $\$ 1.50$ an acre for one irrigation, the usual application being 6 acre-inehes per acre. It will be noticed that four of the farms listed received district water in 1929, and that only one of them used a substantial amount.

\section{Gravity Water Costs Under Mutual Water Companies in the Kaweah River Delta.}

'Tle watel supply for all of the mutual water companies in the Kaweah River Delta is obtained from the natural flow of the Kaweah River. Which is the larest stream in 'Tulare County. 'This river has been used for irrigation sinee 1854 . There now are about 20 ditehes diverting from the river, most of them being organized and operated as mutual water companies. At MeKay Point, a short distanee below where the river amerges from the mountains, it divides into two main channels known as the Kaweah River and St. Johns River. Both branches further divide into a 11 mber of creeks and sloughs spreading over' the delta. 'The dirersions by the companies ineluded in this study are made below McKay Point, from either the main branches or from the creelis.

The diversions are made in aceordanee with a definite schedule which lecognizes the priority of rights. When the stage of the main river above MeKay Point falls below so cubic-feet per second, the water is all diverted into the Kaweal River branch and is distributed to the following ditches:

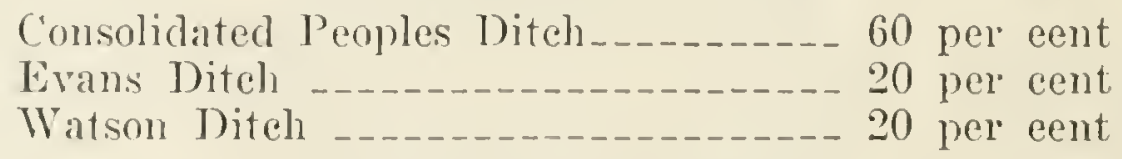

When the stage of the river ag:tin reaches 80 eubie-feet per second, or aftor Oetober 1. the flow is divided equally between the Kawoah River and the st. Johns River blamehes. As the flow of the river increases, of her ditches receive water in the following order:

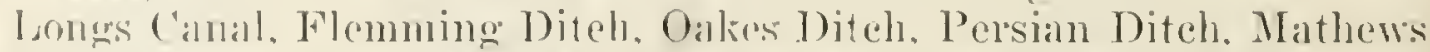
I)ifch, Jennimes Diteh. Modoc Ditch, Faners Diteh, and liphill Diteh.

Only the ditches with the best rights were inchuled in this study berallac many of the other ditches reeeive praetically no water during

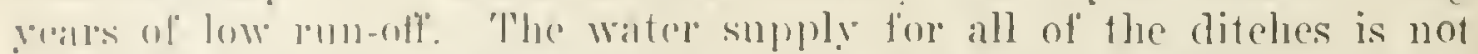
sulfierient to meet the total rerpuirements of the crops glown. 'Th is is

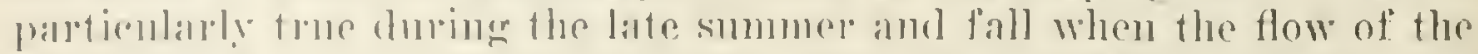
rivere is low. 'The last twelve veals. with the exeeption of 1922 and

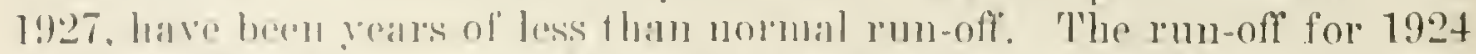
was less that 'The only geale of nopmal pun-off for which data are inchuded in this report is 1920 .

Dorring the propol from 192.t to 1929, inclusive, the Consolidated Peoples 1)iteh received water from 234 to 365 days each vear, or an arerage of "zeis days. 'The average date of the end of the rum was August 


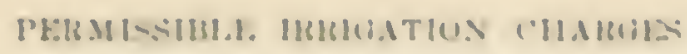

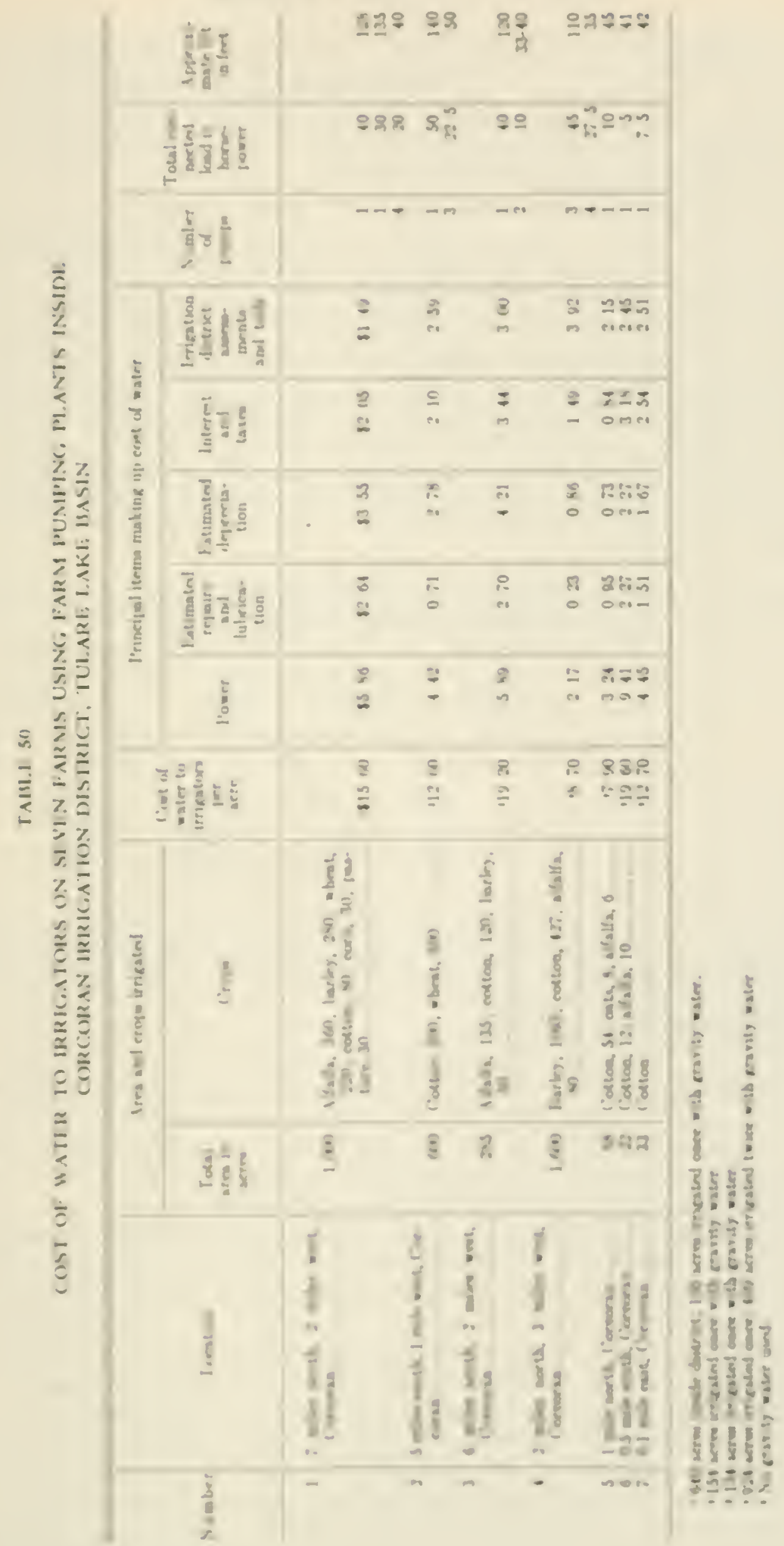




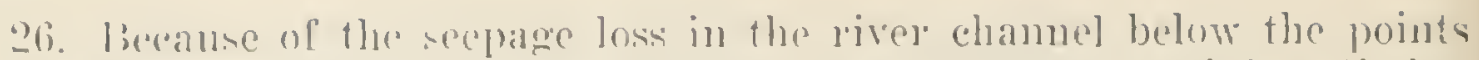
of diversion of the ('onsolidated l'eoples l)itch. the lemaining ditcher

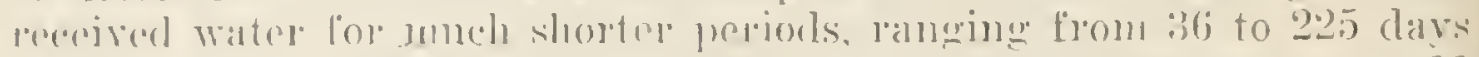

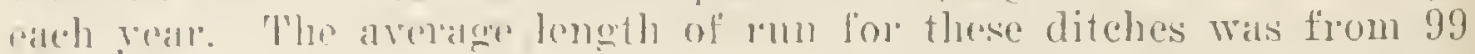

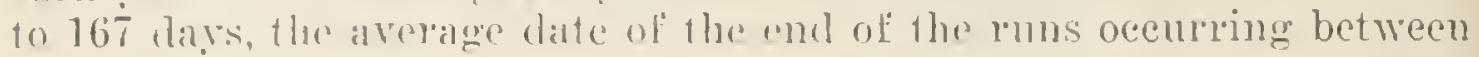
Jume 21 and oluly 12.2 .

Practically all of the alrea served by gravity ditehes in the Kaweah River Delta receives supplemental water from private pumping plants. Becamse of the low rum-off of the livele during the last decade there bas been a laree increase in the mmmber of plants and amomet of power used. There are no data slowing the exact number of pumping plants used to supplenent gravity supplies. but recolds of the Southern California Edison Company. given in Table j1. show the following inereases during the last five rears within the exterior bomdaries of the areas selved by the mutnal water companies ineluded in this study. These figures do not inchude the Elk bayou Area, which receives some water from the Consolidated Penples Ditch. but depends upon pumping fou most of its supply.

TAIBLE 51

EXTENT OF PRIVATE PUMPING ON AREAS SERVED BY SOME OF THE MUTUAL WATER COMPANIES IN THE KAWEAH RIVER DELTA

\begin{tabular}{|c|c|c|c|c|c|}
\hline \multirow{2}{*}{ Year } & \multirow{2}{*}{$\begin{array}{c}\text { Number } \\
\text { of } \\
\text { plants }\end{array}$} & \multirow{2}{*}{$\begin{array}{l}\text { Connected } \\
\text { load in } \\
\text { borsepower }\end{array}$} & \multirow{2}{*}{$\begin{array}{c}\text { Energy } \\
\text { used in } \\
\text { kilowatt hours }\end{array}$} & \multicolumn{2}{|c|}{ Estimated 2} \\
\hline & & & & $\begin{array}{l}\text { Acre-feet } \\
\text { pumped }\end{array}$ & $\begin{array}{c}\text { I'ower } \\
\text { cost' }\end{array}$ \\
\hline $\begin{array}{l}1924 \ldots \ldots \\
1925 \ldots \ldots \\
1926 \ldots \ldots \ldots \\
1927 \ldots \ldots \ldots \\
1928 \ldots \ldots \ldots\end{array}$ & $\begin{array}{l}193 \\
235 \\
320 \\
357 \\
397\end{array}$ & $\begin{array}{l}1,0,51 \\
2,373 \\
3,449 \\
3,835 \\
4,471\end{array}$ & $\begin{array}{l}2,949,671 \\
2,969,626 \\
1,496,505 \\
3,624,667 \\
7,057,890\end{array}$ & $\begin{array}{l}33,600 \\
32,200 \\
4,900 \\
3 ?, 300 \\
72,700\end{array}$ & $\begin{array}{r}s 4,500 \\
5:, 300 \\
\div=, 000 \\
71,900 \\
107,300\end{array}$ \\
\hline
\end{tabular}

Records made available through the courtesy of C. H. Holley. These figures are for full scclions within the general areas serverl by the Consolidated Peoples (exclusive of the Filk Bayou Area), Wans, Farmers, Flanming, Jennings, Mathews, Modoe, Oakes, Persian, "phill and Watson ditches. They are intended to show nnly (he relative amount of pumping and the increase within the same area in a fivo-year period. The total area included is 64 , 6411 acres, of which $29,(i 5)$ acres were actually cropped and irrigated in 19:!1, aceording to crop surveys made hy the Division of Water liesoureses, Situe Departuent of l'ublic Works.

2 Estimated from power companies' records.

Based upon avalable data regarding average depths to the water table, estimating averige drawlowns and effciencies.

"Bascel upon relationshigh between average size of plant and average anount of power used and power rate in

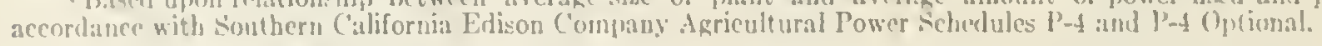

Table 51 indieates that there has been an inerease of mome than 100

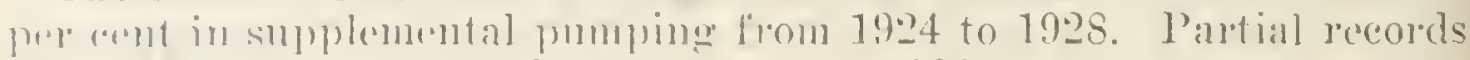
fol 1.929 inclicate a material inclease over 1928.

This enormons inclease in pmuping has resulted in a general lowelind of the water table of from 5 to 15 feet between 1924 and $19090 \mathrm{over}$ most of the alea in the delta receiving gravity water from the above

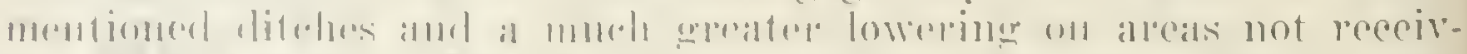
ing relavity water. Before privite pumping was very common, the water table stood within 5 to 10 foret foum the groumel surface in many places. I atrge areas depended entirely upon subirrigation. In some places trees ambl vines were jrigated ouly oceasiomally by surface application. Alfalfa was sometimes irrigated only once or iwiee during a seasom. Since the Inwering of the watel table below the root zone. these eonditions have ehandered amel the anmual surface applieations have increascel. 'These increased applieations are met largely by supple- 
mental pumping. which partially acenums for the trementous increase in pumpluge during the past nix geats.

What data aro avaluhle imliente a relatively low duty of water in

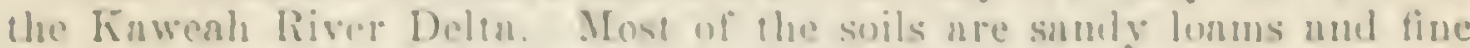
sandy loans. Diversion recoris amel pumping records indicate a net

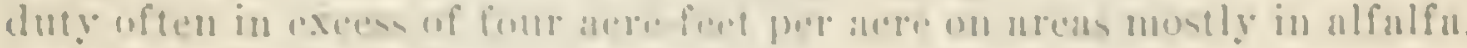
decidunus fonits and rines.

'The lowering of the water table also has had $n$ uoticeable effect merpage from the ditches and unturnl chanmels used for tho distribminn of eravity water. In some of the ereoke that formerly acted as druinage

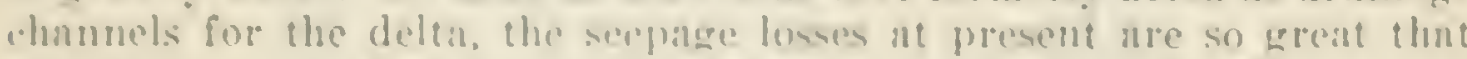
Eravity water seldom reaches the naers on the lower and. This is par. tieularly true of Outside Crove, one of the matural chammels used to

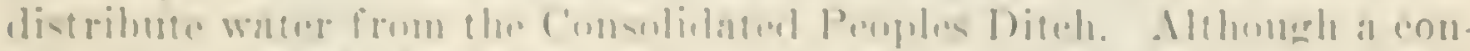
viderable amount of water wis turmed in at the head. practieally no water

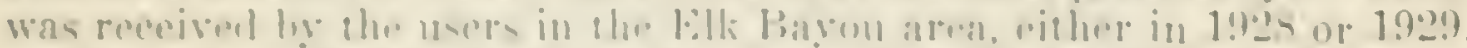

Annther important factor in the eost of where is the type of servien rendered. With the execption of the Comsoliduted leoples Diteh, the companies included in this study deliver water to the head of sinall private ditches. usually in imlividual farms. In most eases the water is delisered on a rotation hasis, the longth of run io each person elepending upon mumber of shares of stock owned. The stock is not appurfenant to the Iand, and. hecanse of a larere number of rexphanges of stock between individnals, tho ratom betwern number of slanres

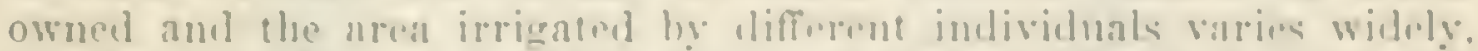
nud at present, on most of the ditohes, it is very ditherult to determine.

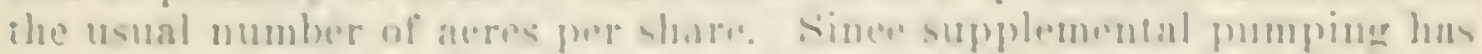

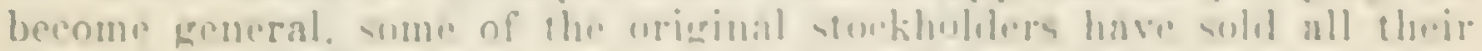

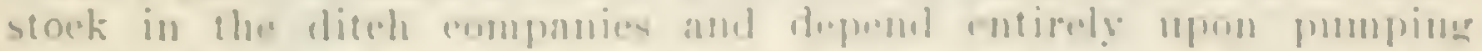

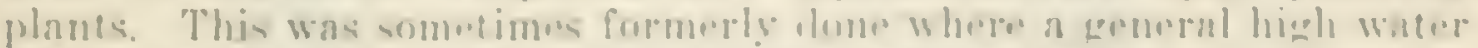

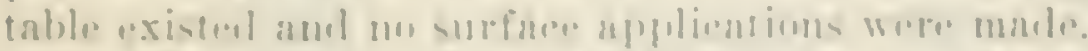

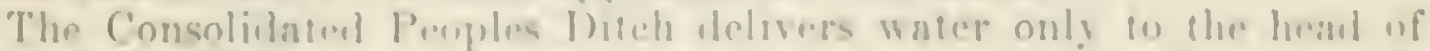

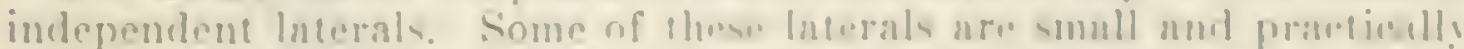

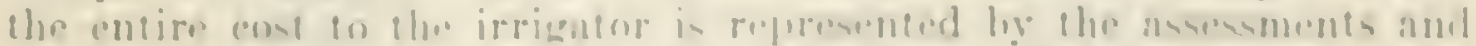

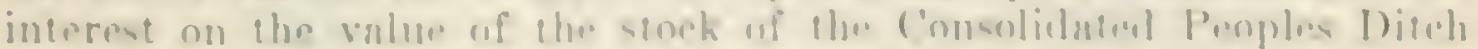

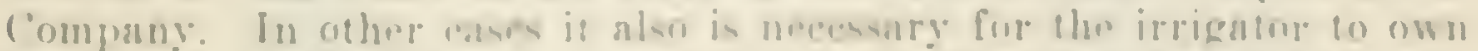

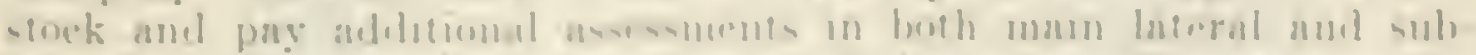

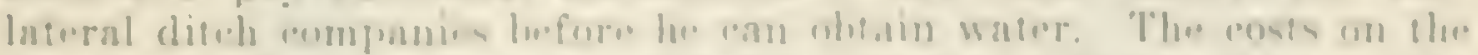

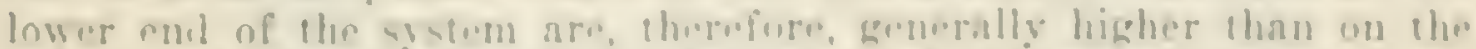

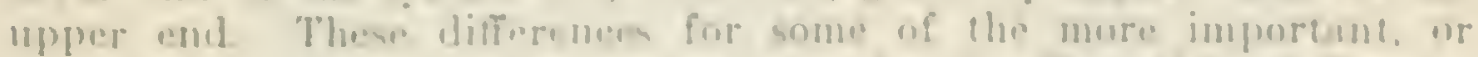

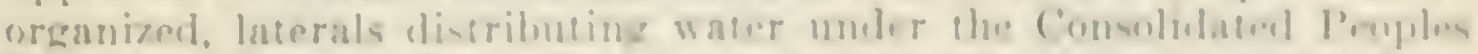

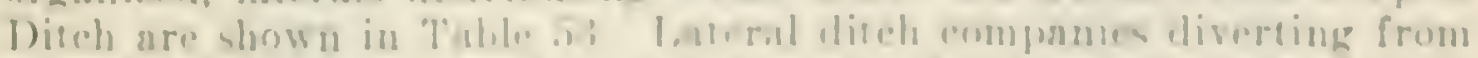

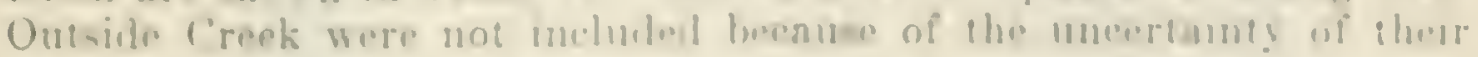
water supply.

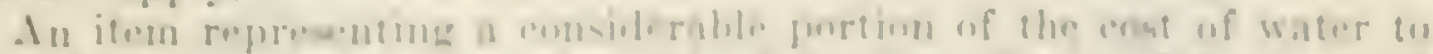

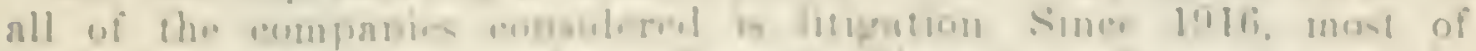
the enmpaniss disertus irom kiswohls hiser have been engaged in

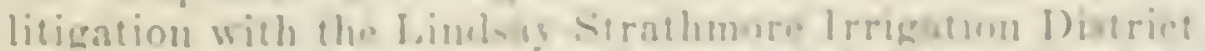

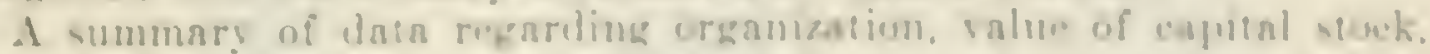

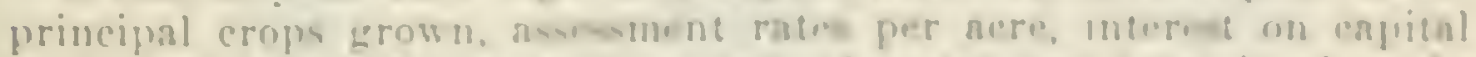

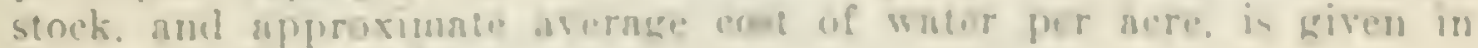
Tablas 5., 53, and 54. 


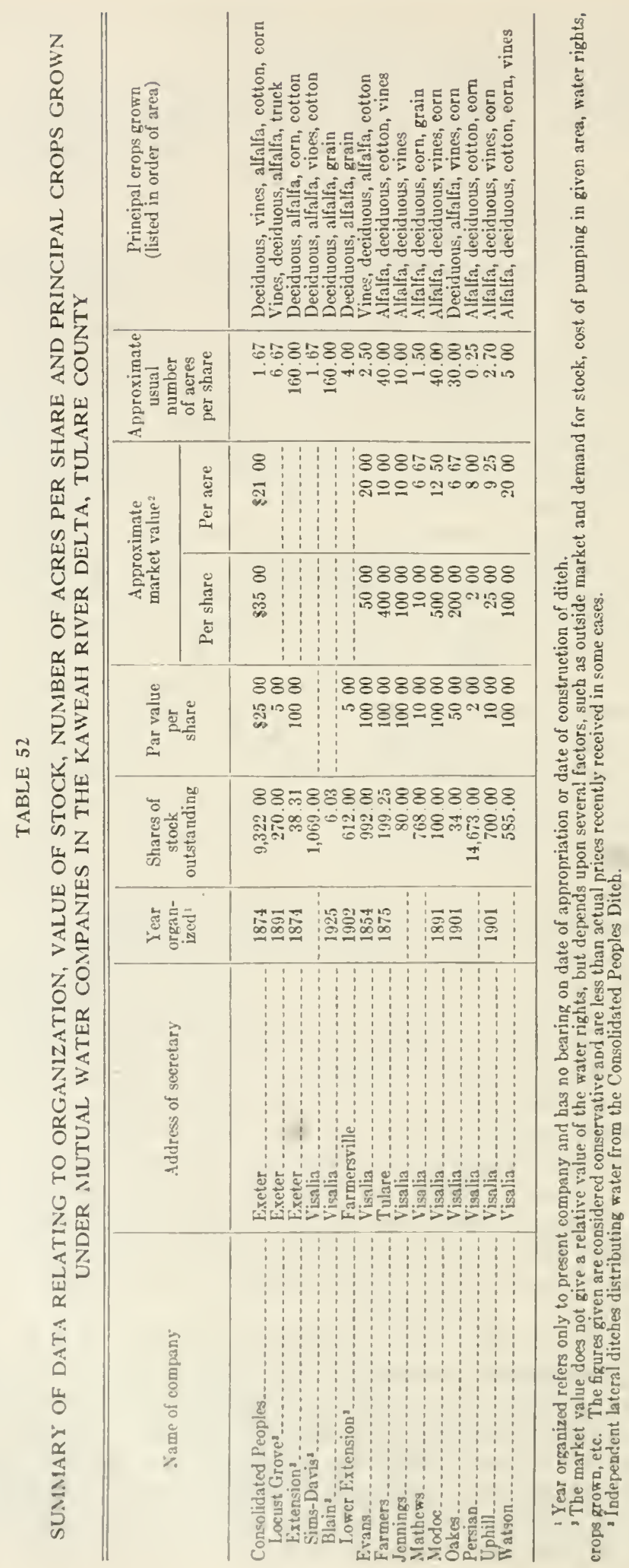




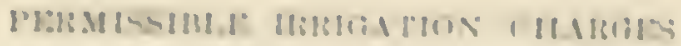

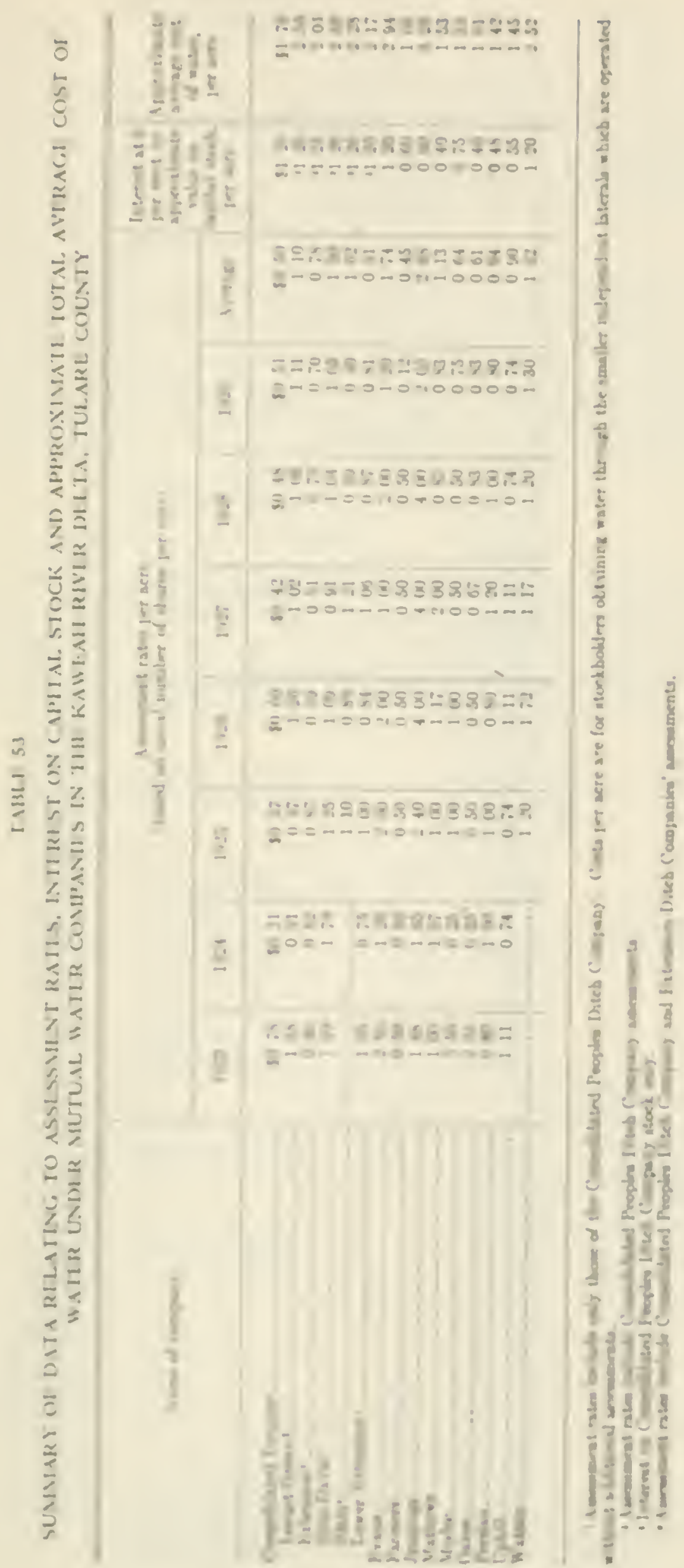




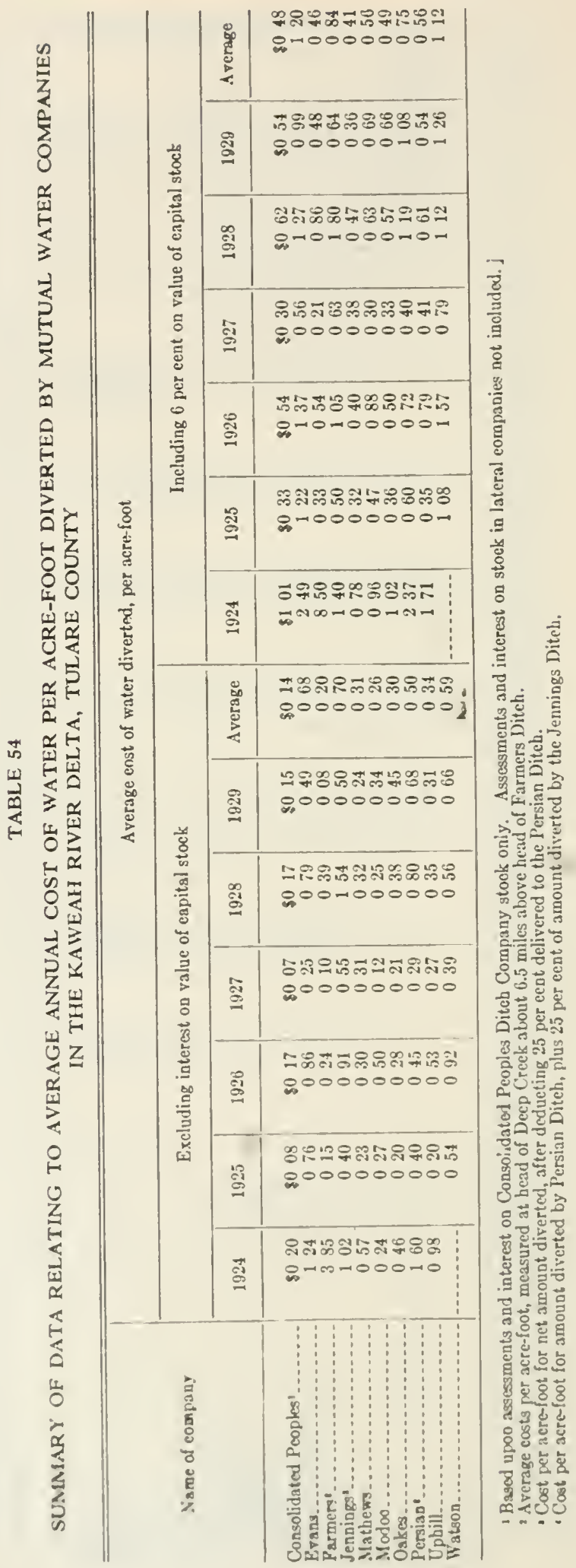


Cost of Water to Irrigators Supplied Exclusively by Farm Pumping Plants. Kaweah Dolla, and Tulo Rivor.Deer Creek Aroas, Excopting Foothlll Cistus Bols.

The cost of irrigation water supplied exelusively by farm pumping plants serving fon furms in Kaweals Dolta Area and seven in the Tule Rirer-1)ere. Creek area is shom in l'ables 6.5 and 56 . It will be notieed that custs on the sevon falms in the T'ule River-Deer Creek aren vary betwe sti and sl:-fll an ace. While these in the linwerh Delta area romeg from

This ditiogente betwern the range in costs in the two groups can not he tahen as an indication that the usunl cost of water supplied by farm mumping plants in the Tule liver-Deer Creek area is less than the

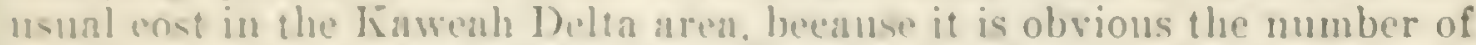
jumping plants included in each group is a small part of the total mumlere in mperation. Howeser. as examples of the cont of water to

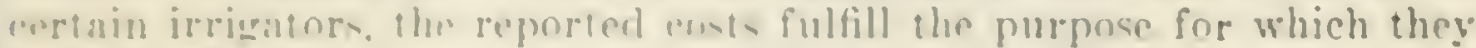
wr.p obtatum

Cos: of Pumping With Deep-vell Turbines.

As explained on page :O, lata on ilse eut of water to irrigntors using firm pumping plants was obtancel for a small number of farms, forty-

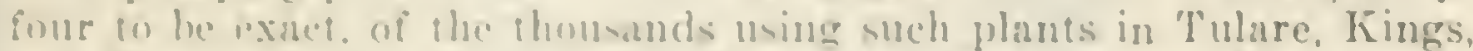
fond Kerm combice. In selecting these samples an attempt was made to incluele representative farms in each of the ahove eomties. How.

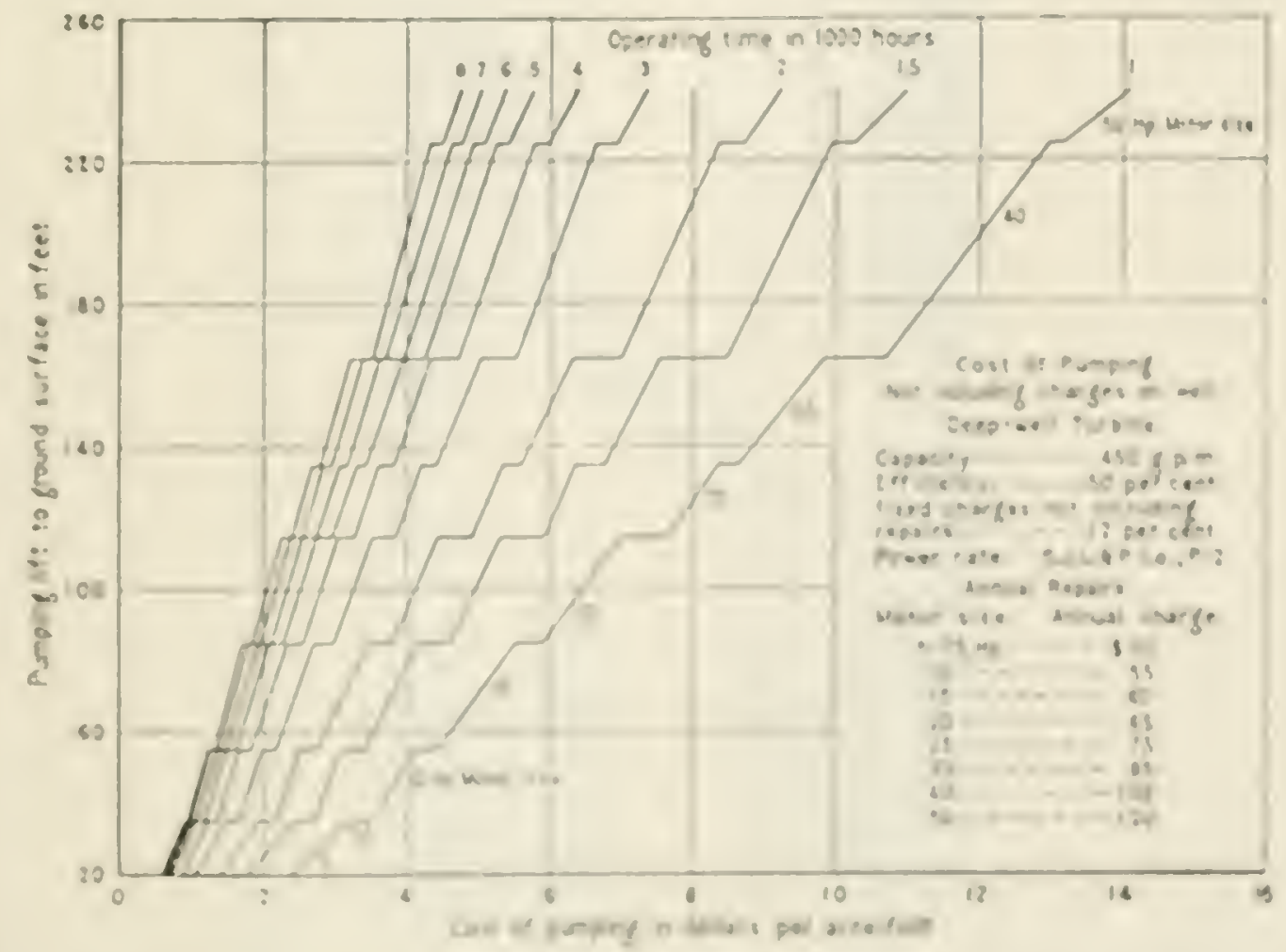

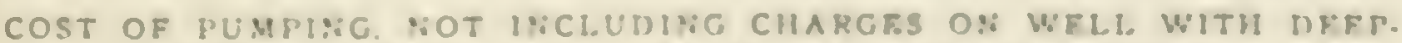
WFI.T. TLRIIUF CAPACITY AH GALIOUS HER MIUUTE 


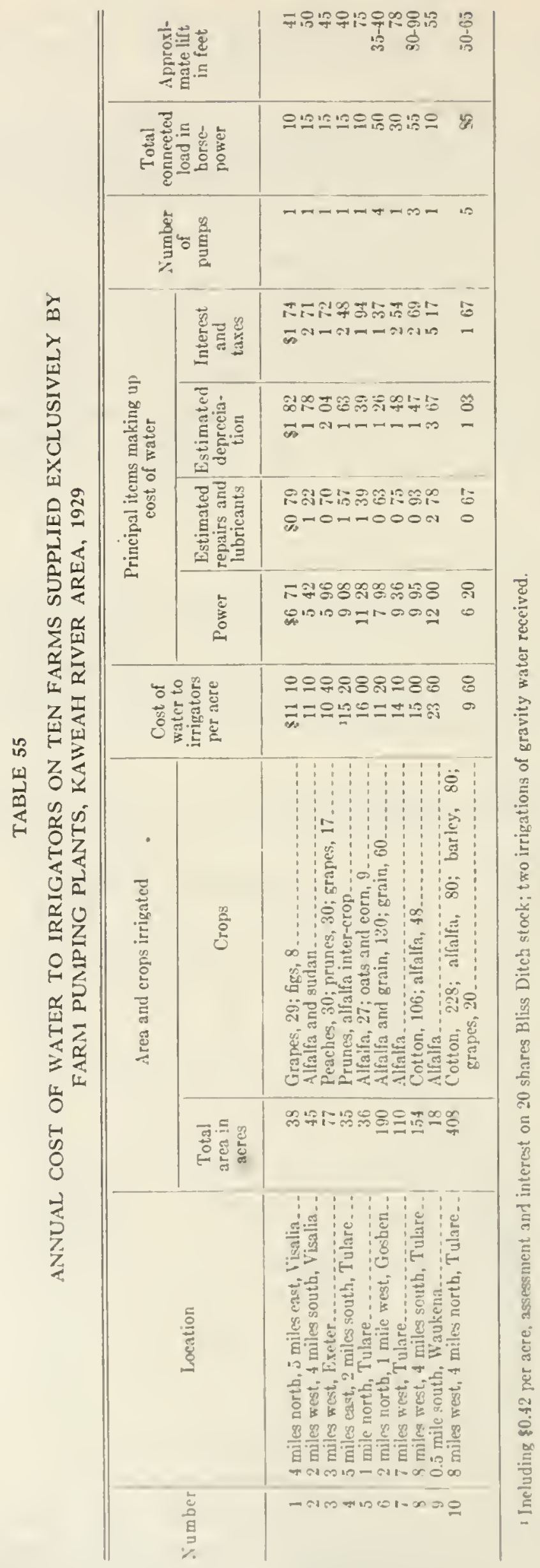




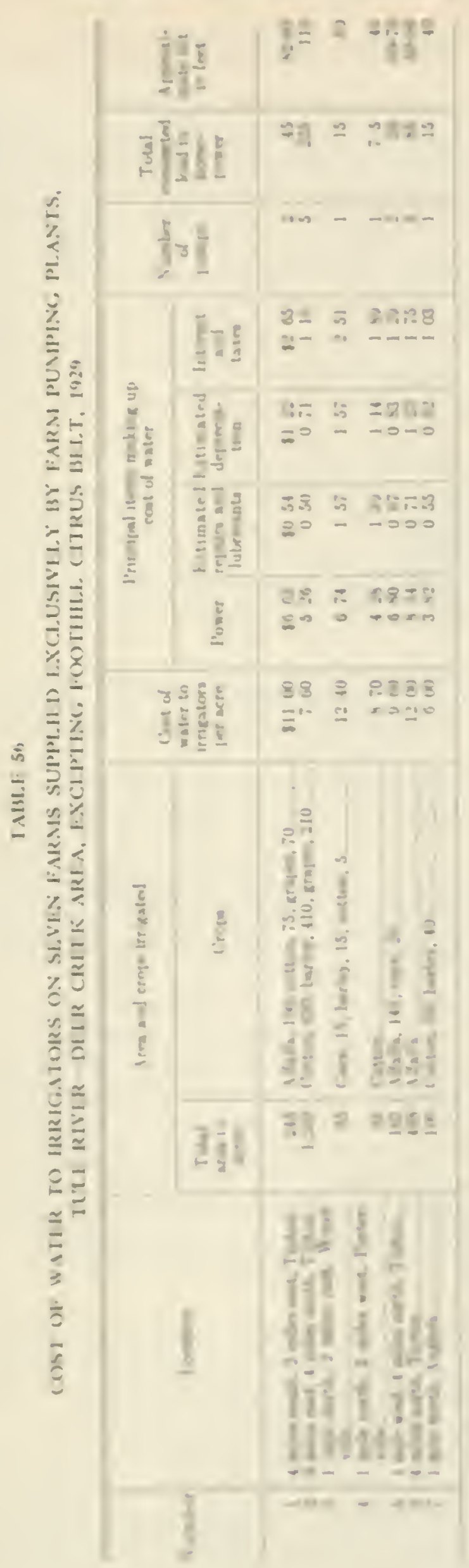




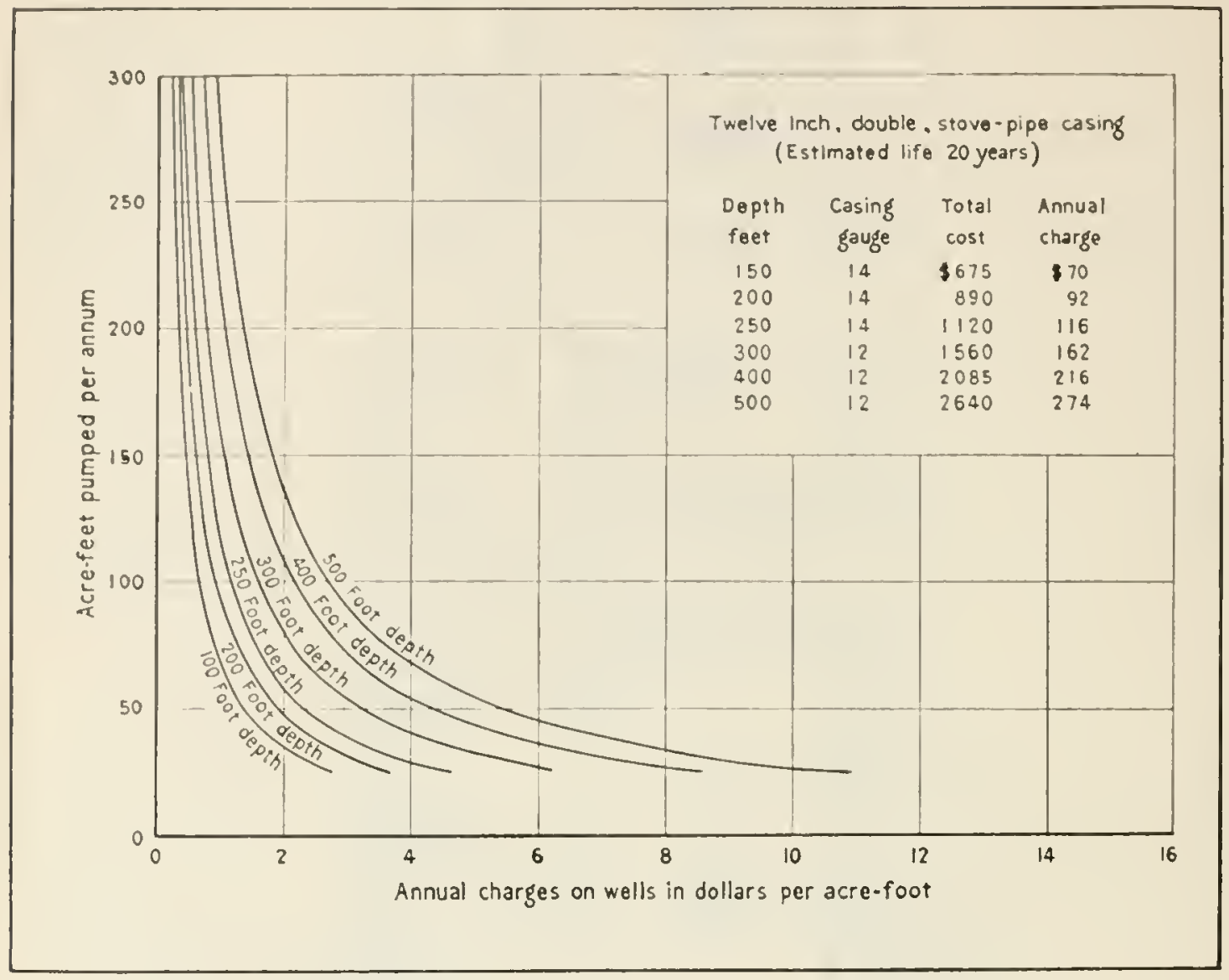

ANNUAL CHARGES ON TWELVE-INCH STOVE-PIPE WELLS.

ever, since, as anticipated, variation in pumping lift, crop requirement, installed plant capacity per acre, hours of plant operation per anmum. etc., was great, no attempt was made to compare the cost of water in one area with that in another.

In order to show the effect of the pumping lift and the duration of operation on the cost of pumping per acre-foot with a deep well turbine delivering one cubic foot per second (450 gallons per minute) Plate VI has been prepared. The total ammal cost of pumping includes interest at 6 per cent, taxes at 1 per cent, and depreciation at 5 per cent on the cost of the deep-rell turbine. starting rquipment, and lousing. Prices which previled in the first six months of 1930 were userl in computing the capital cost. The annual allowance to cover repairs and lubrieation is indieated on the diagram. Power charges were made according to the P'-2 schedule of the San . Toaquin Light and power Corporation.

The total ammal cost of pumping, inchuding the above items but not fle ammil whires on the well, was eomputed for operation periods of

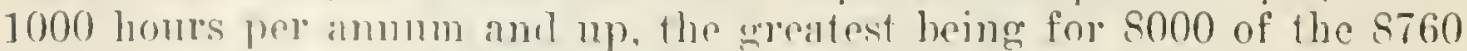
lions which malis mp the usual calendal year.

'The slanting, discontinnous lines on Plate VI show the estimated ; )umping costs per acre-foot for pumping lifts of from 20 to 240 feet for the indicated hours of opelation. Diseontinuty results from the necessify of increasing the size of motor, pump head, and starting equipment at intervals as the lift incerasos. Notor simes are shown to the right of 


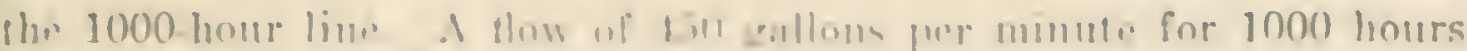

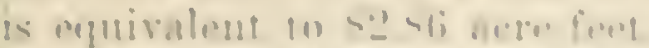

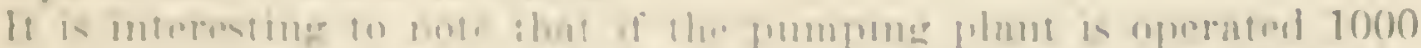

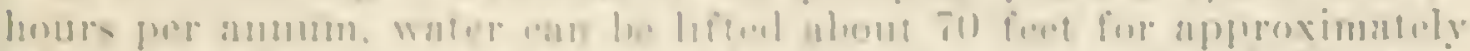

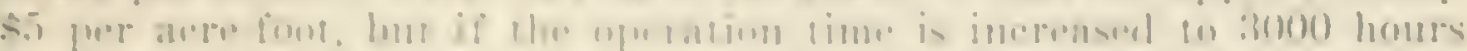

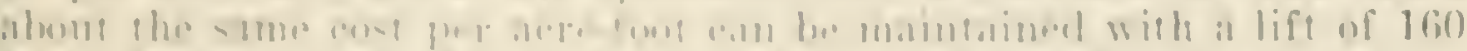

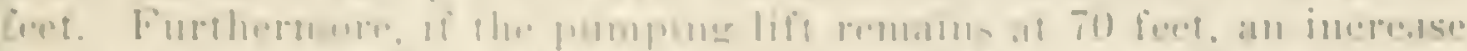

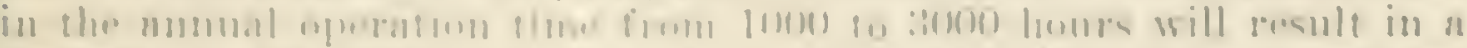

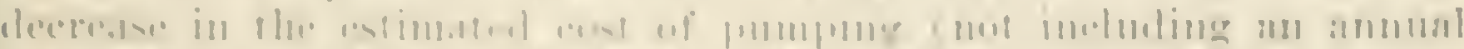

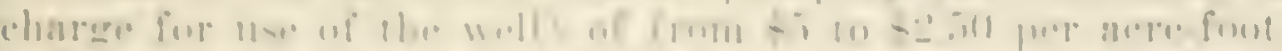

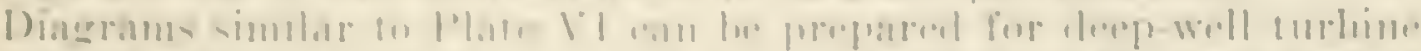

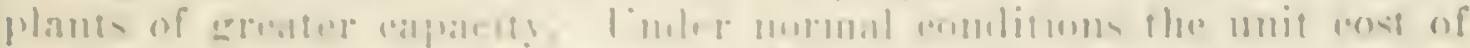

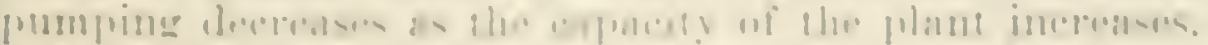

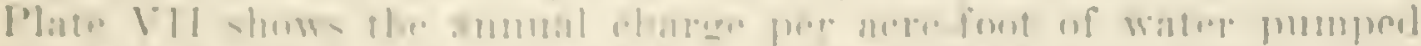

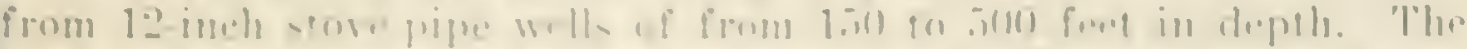

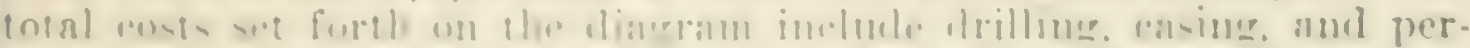

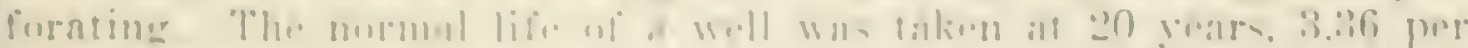

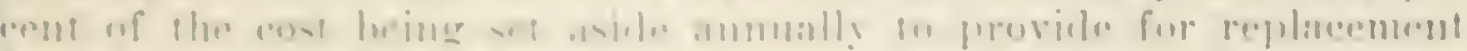

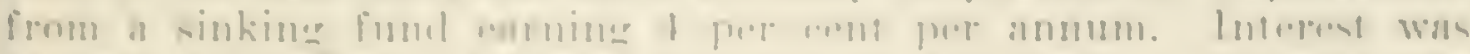

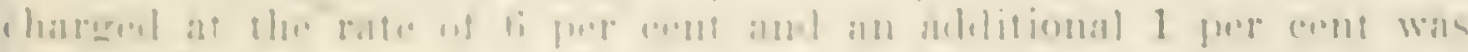
: llowmel for porres.

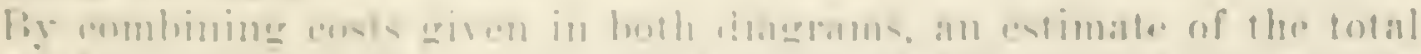

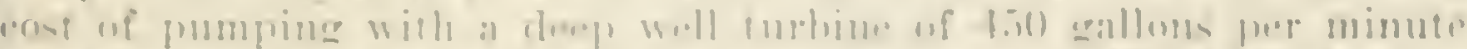

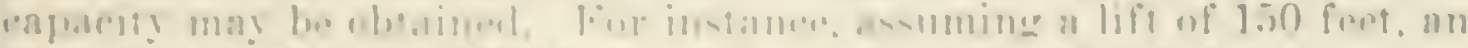

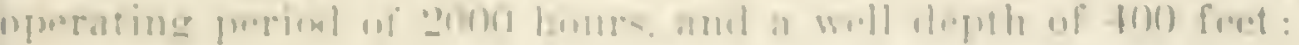

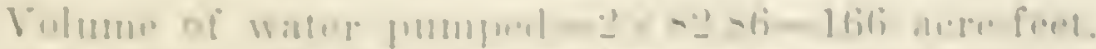

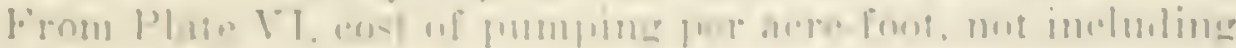
bhan -

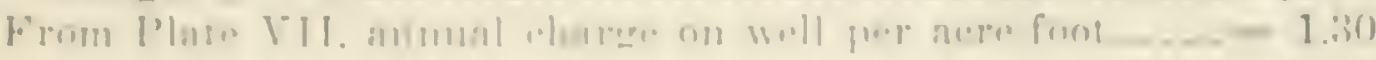

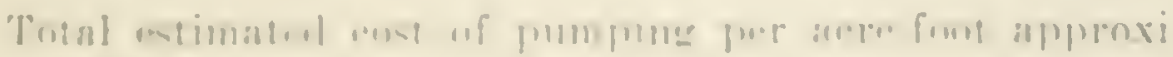

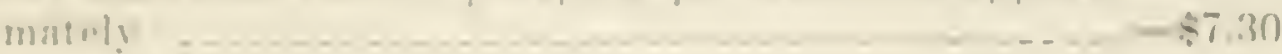



PUBLICATIONS

DIVISION OF WATER RESOURCES 


\title{
PUBLICATIONS OF THE
}

\section{DIVISION OF WATER RESOURCES}

\author{
DEPARTMENT OF PUBLIC WORKS
}

\author{
STATE OF CALIFORNIA
}

Whon the Department of Jublle Worlss was created In July, 1921, the Stato Water Commisslon was suceeded by the Division of Water Rlghts, and the Department of Englneerlng was succeeded by the Divialon of Enslneering and Irrisation In all dutles except those pertalning to State Archltect. I3oth the DIrlslon of Water Ilights and tho Divlsion of Englnecring and Irrigatlon functloned untll August, 1939. when thay wers consolldated to form the Dislston of Water Itesources.

\section{STATE WATER COMMISSION}

First Report, State Water Commission, March 24 to November 1, 1912.

Second Report, State Water Commission, November 1, 1912, to April 1, 1914.

- Blennial Report, State Water Commission, March 1, 1915, to December 1, 1916.

Blennial Report, State Water Commission, December 1, 1916, to September 1, 1918.

Biennial Report, State Water Commission, September 1, 1918, to September 1, 1920.

\section{DIVISION OF WATER RIGHTS}

- Bulletin No. 1-Hydrographic Investigation of San Joaquin River, 1920-1923.

- Bulletin No. 2-IKings River Investigation, Water Master's Reports, 1918-1923.

- Bulletin No. 3-Proceedings First Sacramento-San Joaquin River Problems Conference, 1924.

- Bulletin No. - - Proceedings Second Sacramento-San Joaquin River Problems Conference, and Water Supervisor's Report, 1924.

Bulletin No. 5-San Gabriel Investigation-Basic Data, 1923-1926.

Bulletin No. 6-San Gabriel Investigation-Basic Data, 1926-1928.

Bulletin No. 7-San Gabriel Investigation-Analysis and Conelusions, 1929.

- Biennial Report, Division of Water Rights, 1920-1922.

- Biennial Report, Division of Water Rights, 1922-1924.

Biennial Report, Division of Water Rights, 1924-1926.

Biennlal Report, Division of Water Rights, 1926-1928.

\section{DEPARTMENT OF ENGINEERING}

- Bulletin No. 1-Cooperative Irrigation Investigations in Callfornia, 1912-1911.

- Bulletin No. 2-Irrigation Distrlets in Californla, 1887-1915.

Bulletín No. 3-Investigations of Economic Duty of Water for Alfalfa In Sacramento Valley, California, 1915.

- Bulletir No. 1-I'reliminary Report on Conservation and Control of Flood Waters in Coachella Villey, California, 1917.

- Bulletin No. 5-Report on the Utilization of Mojave River for Irrigation in Vletor Valley, California, 1918.

- Bulfrtin No. 6-Cilifornia Irrigration District Iaaws, 1919 (now obsolete).

Buljelln No. 7-Use of water from King-Rlver, California, 1918.

- Bulletla No. 8-Fiood Proble-ins of the Caliveras River, 1919.

Bulletin No. 2-Water Resources of Kern River and Adfacent Streams and Their Utllization, 1920.

- Bienulal Report. Denartment of Engineering, 1907-1908.

- Blennlar Renort, Devartment of Finflneering. 1908-1910.

- juennial Jeport, Denartment of Engincering. 1310-1912.

- Iblennial Ienort, Dejartment of Fngineering, 1912-1911.

- Iblennlal denport, Debirtment of linglneering. 1914-1916.

- Blenilal Iteport, Deprament of Engineering, 1916-1918.

- Bjennial leport, Demarmene of Linglnecring, 1918-1920.

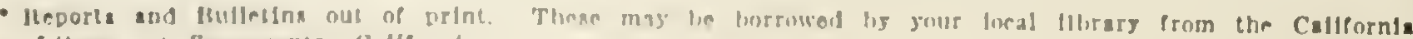
Slab. Litirars at Becramento. Collerinla 
including Reporta of the Fornier Divislon of Enolnecrino and Irrloatlon

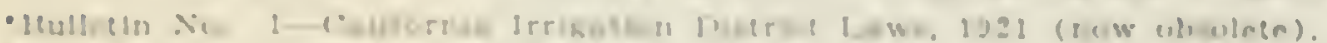

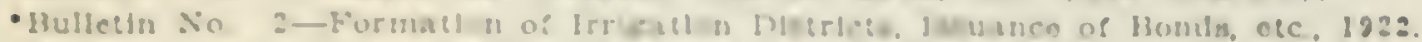

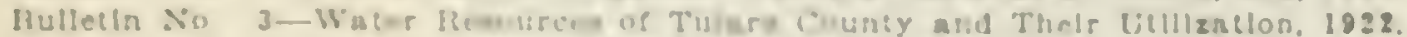

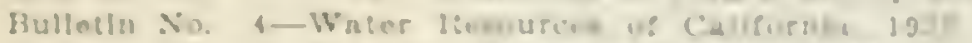

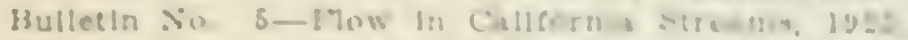

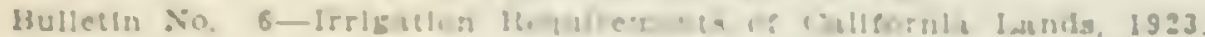

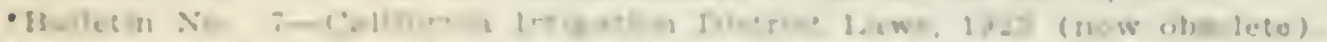

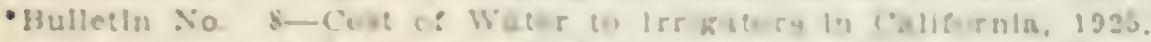

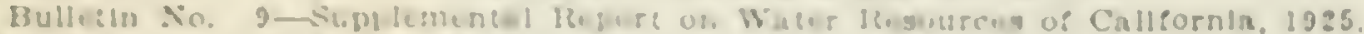

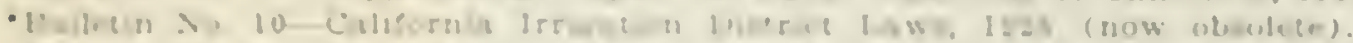

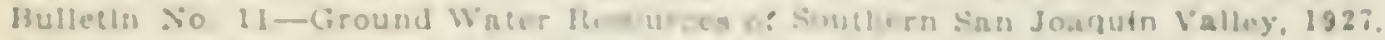

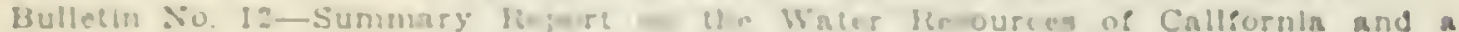

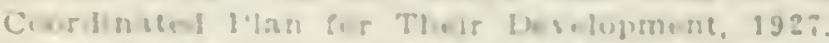

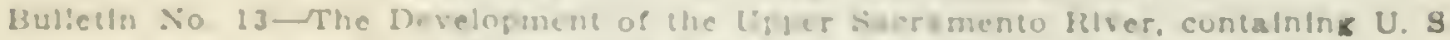

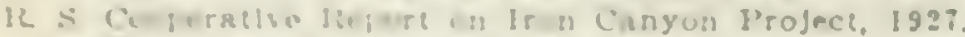

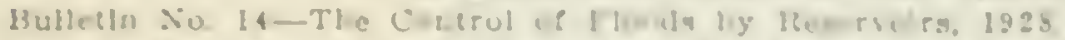

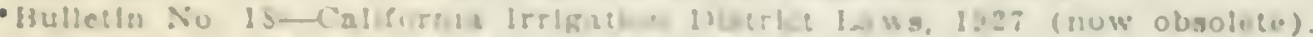

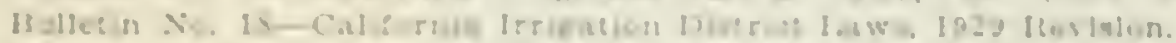

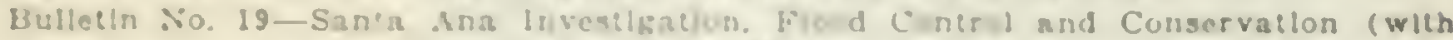
in $h=2$ o: $82 \pi i=)$, igts

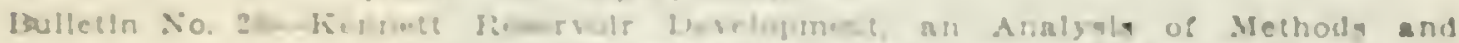

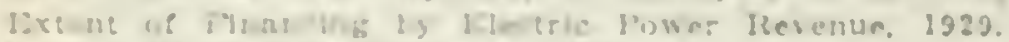

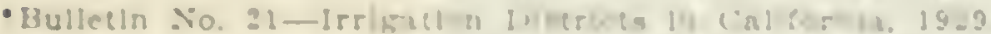

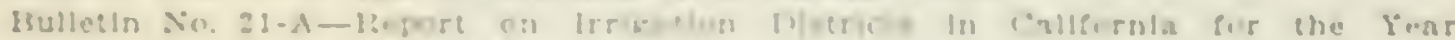
1523.1210

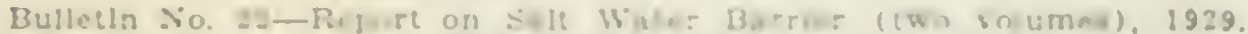

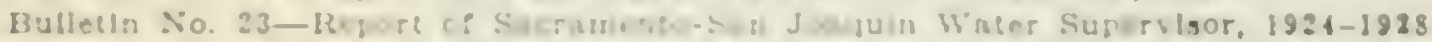

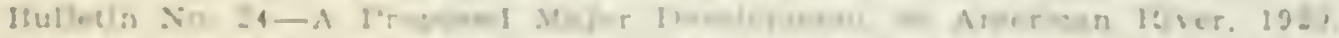

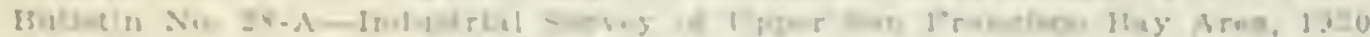

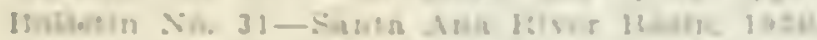

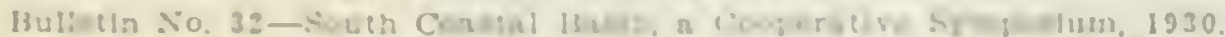

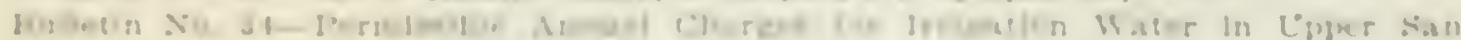

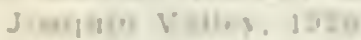

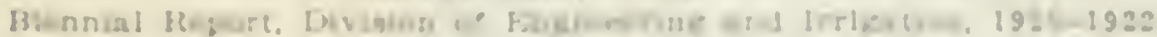

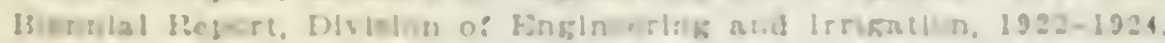

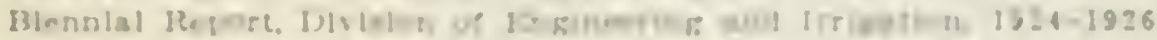

COOPERATIVE ANO MISCELLANEOUS REPORTS

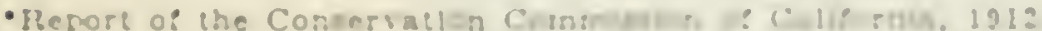

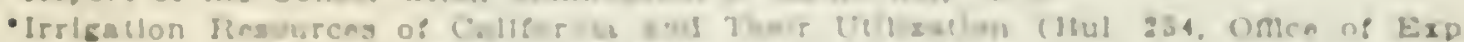

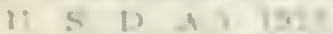

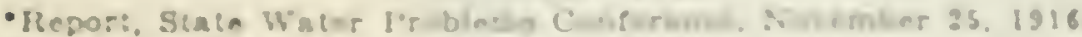

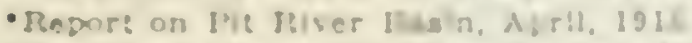

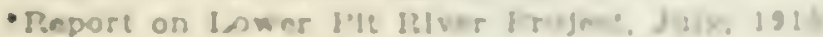

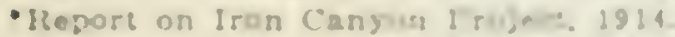

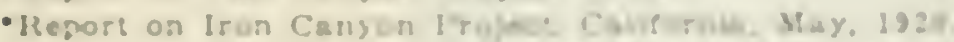

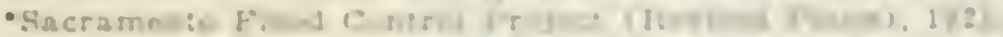

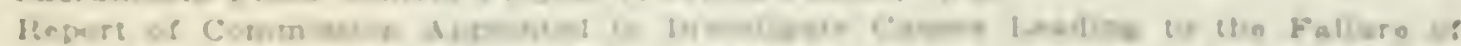

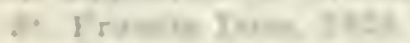

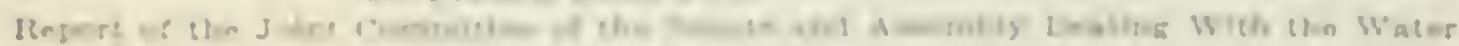

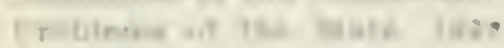

\section{PAMPLETE}

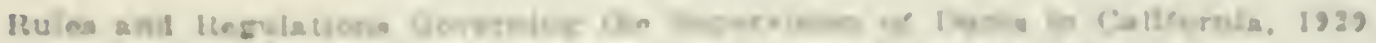

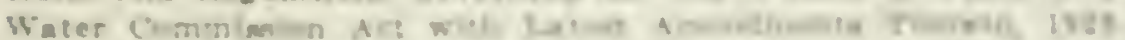

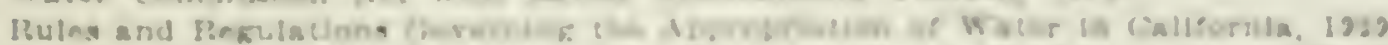

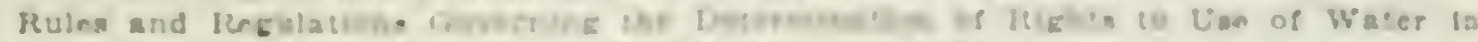

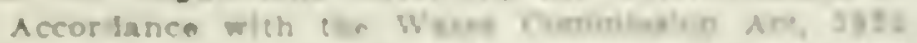

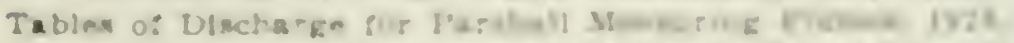

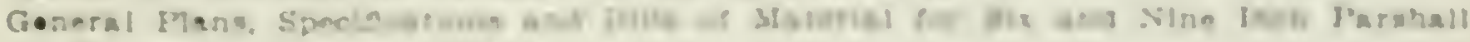
Mคasurlng 17um 9. 1937

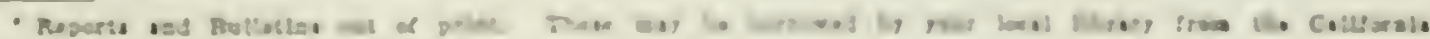

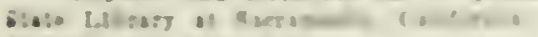

$\$ 0999 \quad 18-30 \quad 23 \%$ 


THIS BOOK IS DUE ON THE LAST DATE STAMPED BELOW

AN INITIAL FINE OF 25 CENTS WILL BE ASSESSED FOR FAILURE TO RETURN THIS BOOK ON THE DATE DUE. THE PENALTY WILL INCREASE TO 50 CENTS ON THE FOURTH DAY AND TO $\$ 1.00$ ON THE SEVENTH DAY OVERDUE.

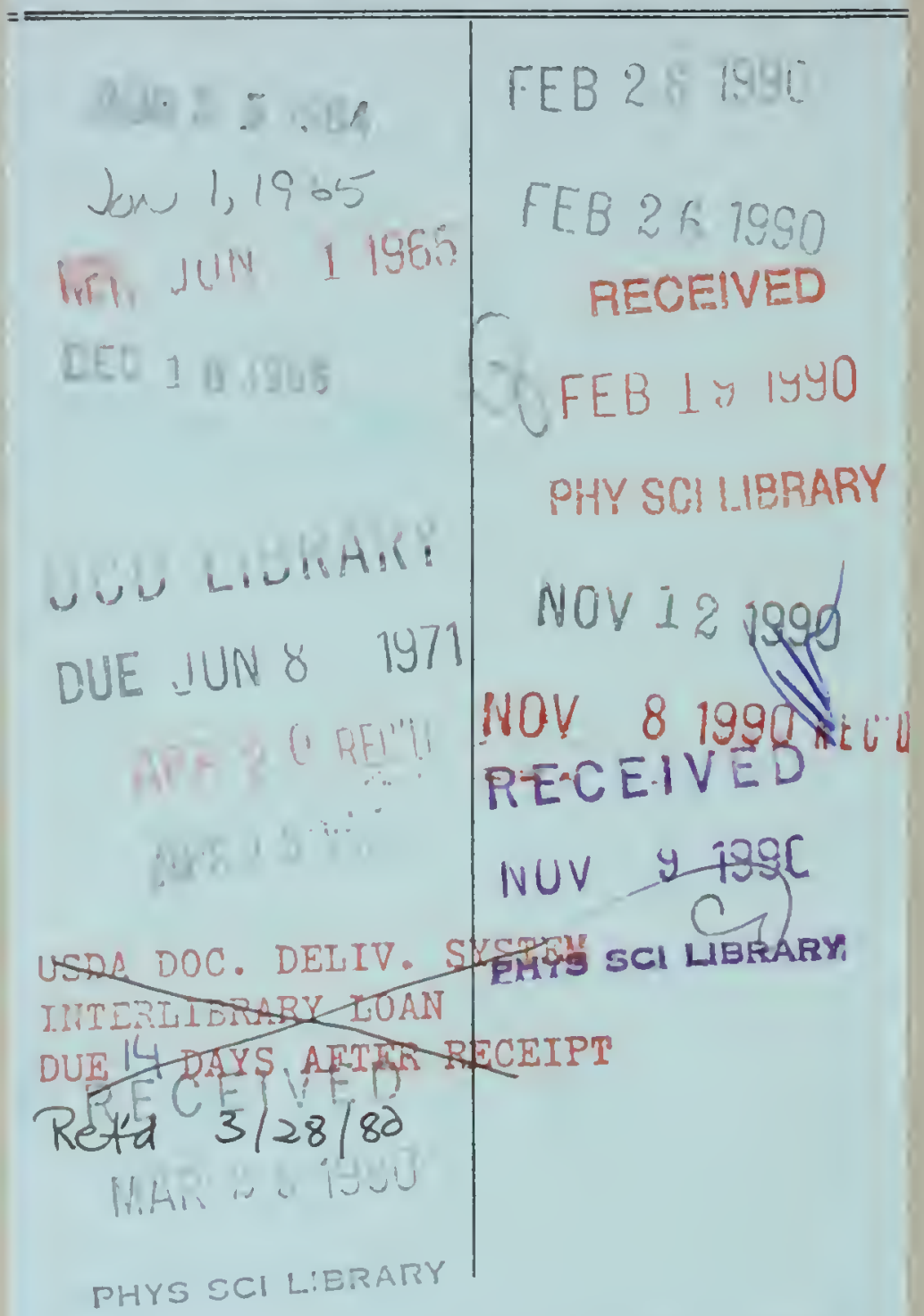


Calif. Division of C2 water resourcos. A2

\section{callo \\ PHYSTAL SCDRGES QBRERY}

\section{EIBRAR T UNIVERSITY OF CALUFORNLA DAVIS 111598}


